


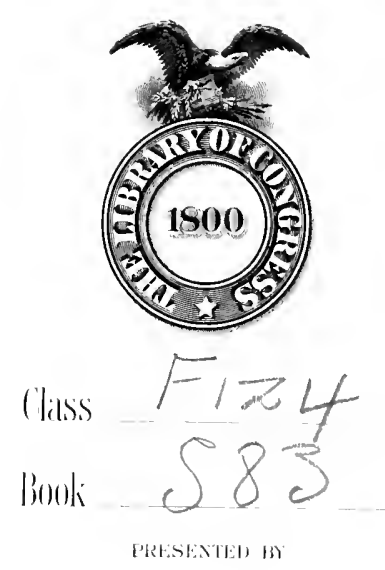






\title{
A POLITICAL HISTORY OF THE STATE OF NEW YORK
}

\author{
$1865-1869$
}

By

HOMER A. STEBBINS, Ph.M., LL.B.

SUBMITTED IN PARTIAL. FULFILMENT OF THE REQUIREMENTS

FOR THE DEGREE OF DOCTOR OF PHILOSOPHY

IN THE

Faculty of Political Science

Columbia University

NEW YORK

1913 
Copyright, I9I3

BY

HOMER A. STEBBINS 
TO

My Mother

REBECCA MCCABE STEBBINS

AND

MY FATHER

MORRIS WILLIAM STEBBINS 

PREFACE

THIS monograph results from the author's interest in the politics of the United States and from Professor William A. Dunning's suggestion that a study be made of the political conditions in New York State corresponding to the Reconstruction period in the South. Although the immediate effects of the Civil War had their direct manifestation in the disturbed social, economic and political conditions of the South, with the resulting Reconstruction legislation of the Radical Congress; it is also true that the reflex action of the War and of the Reconstruction movements produced a disorder which, while more political than social or economic, nevertheless caused a general wave of disturbance to sweep over the Northern States. This wave was especially noticeable in the reorganization of political parties in the North. In no Northern State was the reconstruction of political parties more marked than in New York, and as it, then as now, was the pivotal State of the Union politically, it is deemed to be not only of interest but of peculiar importance to understand the political forces at work in the Empire State during the time corresponding to the early Reconstruction period of the South.

In the development of this study it has been necessary to rely almost wholly on the newspapers of the period, as there is a dearth of other published material. The few memoirs, biographies and autobiographies which cover these years contain but little of direct value for New 7] 
York politics. Interviews with former politicians offer an untrustworthy source of information, due to the fallibility of memory, prejudice, and the natural failure to tell the whole truth, if detrimental to the person interviewed. The papers of the day thus become practically the sole source.

Eight New York City and fourteen up-State papers have been carefully studied for the period. Statements of fact have been compared in two or more papers of opposite political faith. Where a serious divergence has appeared the consensus of statement of all the New York City papers has been ascertained. Special attention has been paid to editorial bias; and causes for animosities, local or general, have been taken into consideration. The attempt has been made, at least, to give a reasonable interpretation of the facts, and assign to Republicans and Democrats their just due.

Relative to the up-State press it has been my aim to have the northern, southern, western, eastern and central sections of the State represented by their leading editors, in order to balance New York City with the State politically. In many cases it was found that the up-State journals, aside from local political currents, largely reproduced the editorial opinion of their favorite New York City organ. But in a refreshing number of cases, able and independent editorial opinions were found. This statement is especially true of the following editors: Carroll E. Smith, Syracuse Evening Journal; Charles E. Smith, Albany Evening Journal; Ellis $\mathrm{H}$. Roberts, Utica Morning Herald, (Republicans); and of William Cassidy, Albany Argus; and William Purcell, Rochester Daily Union and Advertiser, (Democrats).

I wish to extend appreciation and thanks to Dr. Joseph A. Mosher, of the College of the City of New 
York, for friendly criticisms in reading the manuscript, and likewise to my wife, Elizabeth Tredwell Stebbins, whose unfailing sympathy during the progress of the study, and aid in clerical details, as well as in proofreading, have been invaluable. My thanks, however, are chiefly due to Professor William A. Dunning, who, in reading the manuscript and proof, has given me the benefit of his scholarly grasp of the Reconstruction period.

New York, April 3, 1913.

Homer A. Stebins. 



\section{TABLE OF CONTENTS}

\section{CHAPTER I}

CHAPTER I
Introduction . . . . . . . . . . . . . . FAE

\section{CHAPTER II}

Social and Economic Survey of New York at the Close of THE Civil WAR

New York to be proud of its war record . . . . . . . . . . . 29

Advance of New York. . . . . . . . . . . . . . . 30

Congested conditions in New York City .. . . . . . . . 3I

Sanitation. . . . . . . . . . . 32

Inefficiency of the Board of Health . . . . . . . . . 34

Liquor traffic, prostitution. . . . . . . . . . . . . 35

Shipping of New York . . . . . . . . . . . . . . . . . . 36

Agriculture of New York . . . . . . . . . . . . . 36

Condition of the State Treasury . . . . . . . . . . . . 37

The Canal receipts . . . . . . . . . . . . . . . . . . . 38

Governor Fenton allays unrest. . . . . . . . . . . . . 39

Steam railroads of the State . . . . . . . . . . . . . . . . . . . 39

The State Banks . . . . . . . . . . . . . . . . . . . . 40

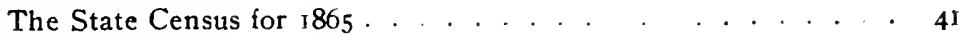

Depew's report. . . . . . . . . . . . . . . . . . . . . 42

Suspicions concerning Depew's report. . . . . . . . . . 43

\section{CHAPTER III}

Party Politics in New York During 1865

Fenton defeats Seymour in 1864 . . . . . . . . . . 44

Johnson and the Radicals . . . . . . . . . . . . . . . . 45

State Conventions in 1865 sustain Johnson's policy . . . . . 47

New York State Democratic Convention of 1865 . . . . . . . . . 48

Change of policy developed . . . . . . . . . . . . . . . 48

Comments of the Times and the World. . . . . . . . . . . . 49

The Democratic platform of $1865 . . . .3 . . .30$

Charges of the Union State papers. . . . . . . . . . . . 51 
Democrats nominate successful soldiers.

Comments on General Slocum. ......................

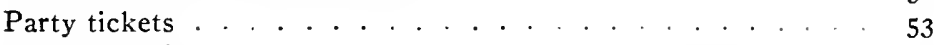

Newspapers' comments on the nominations and convention. . . 54

The State Convention of the Union Party of New York . . . . 55

Civilians give way to the soldier candidates. . . . . . . . 56

General Barlow receives the chief nomination . . . . . . 57

Consensus of opinion Radical . . . . . . . . . . . . 58

Contention of the New York factions for Johnson's favor. . . 59

Explanation of Depew's withdrawal . . . . . . . . 60

Radicals affirm right of loyal Southerners to vote on reorganization of the State governments . . . . . . . . . . 6r

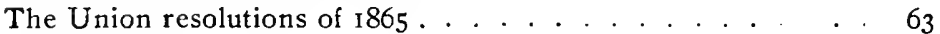

The Campaign . . . . . . . . . . . . . . . 65

Three reasons of the Evening Post for inactivity of campaign . . 65

The Herald supports Raymond . . . . . . . . . . . . . . . . 66

Personal issues in the campaign . . . . . . . . . . . . . . 67

Controversy over Weed and Robinson . . . . . . . . . . . . 68

Charges against Generals Barnum and Barlow . . . . . . . . 69

Defence of General Barlow . . . . . . . 70

Charges against General Slocum; defence . . . . . $7 \mathbf{r}$

Democrats plead for consideration not based on Seymour's Chicago platform . . . . . . . . . . . . . . . . 72

Seymour's and Seward's addresses. . . . . . . 72

Charges against the legislature . . . . . . . . . 73

Campaign closes in a whirlwind of personal defamation. . . . 74

Democrats' past record reviewed by Radicals. . . . . . . . . . 75

Union ticket wins. . . . . . . . . . . . . . . . . . . . 77

New York City and up-State editorial comments . . . . . . 78

Reasons for a campaign of personal defamation. . . . . . . . 79

CHAPTER IV

\section{Attitude of New York toward Reconstruction}

National politics. . . . . . . . . . . . . . . 8I

Motif in the politics of 1866 . . $\quad \ldots . . . . . . .882$

The Philadelphia Convention .... . . . . . . . . 83

Raymond's address sounds his political death knell . . . . . . . 84

Raymond declines renomination to Congress. . . . . . . . 86

Swinging round the circle, Seward's downfall . . . . . . . 87

Political terminology . . . . . . . . . . . . . 88

The Preliminary Conservative Union State Convention. . . . . . 90

The Union Republican State Convention of $1866 \ldots . . . .9$ 9r

The western and eastern parts of the State in conflict. . . . . 92 
Lieutenant-Governor Alvord dropped for General Woodford. . . 93 The western State papers fall in line . . . . . . . . . . 94

Platform a strong Radical document . . . . . . . . . 95

General Barlow shows lack of ill-will. . . . . . . . . . . . . 96

Democrats exultant over Fenton's renomination . . . . . 97

Radical up-State papers united against Johnson. . . . . . . . 98

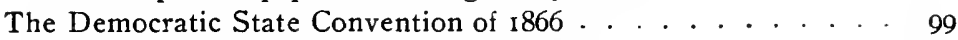

Hoffman and Dix the leading candidates for Governor . . . . . 100

Tammany spars for time. . . . . . . . . . . IOr

Sandford E. Church springs a coup d'état . . . . . . . . . 102

Weed concedes the defeat of Dix. . . . . . . . . . . 103

Church explains. . . . . . . . . . . . . . . 104

Pierrepont's effrontery ... . . . . . . 105

Hoffman accepts the nomination. . . . . . . . . . . . . . . I06

Democratic organs give subdued accounts of coup d'état . . . 107

Platform reaffirms principles of Philadelphia Convention . . . . I09

Dearth of convincing statements from Democratic press . . . . Iro

Conservative Unionists displeased over condemnation of $\mathrm{New}$

York City commissions . . . . . . . . . . . . . III

Weed gives his views on the Albany Convention. . . . . . I12

James Gordon Bennett experiences a change of heart. . . . . II2

\section{CHAPTER V}

\section{The Campaign of 1866}

Campaign active, national questions in forefront . . . . . . II5

Hoffman accused of being the "Ring's" candidate. . . . . . . II6

Johnson's use of the spoils system hurts Unionist cause. . . . . II

Use of the word happen . . . . . . . . . . . . I18

Henry Ward Beecher's letter . . . . . . . . . . . . I19

Greeley answers Beecher .. . . . . . . . . . I 20

The Fenian agitation . . . . . . . . . . . . . I2I

Excise movement . . . . . . . . . . . . . . . . . . 123

Hoffman the candidate of the grog shops. . . . . . . . . 124

The Anti-rent agitation. . . . . . . . . . . . 125

Southern massacres, Nast's pictures, Nasby's letters, and ill treatment of Union prisoners in the South, powerful Radical

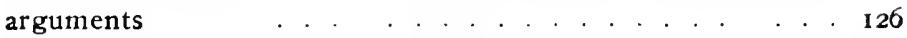

Conkling strikes keynote of campaign . . . . . . . . . 127

Hoffman tours State for Democrats . . . . . . . . . . . 129

Dissensions in Radical ranks. . . . . . . . . . . . I 30

Syracuse center of the up-State campaign ........ I3I

The September elections. . . . . . . . . . . . . 132 
Fenton carries State, great Democratic majority in New York City.

. . 133

Local elections in New York City . . . . . . . . . . . . . ${ }_{134}$

Legislature Unionist by great majority. . . . . . . . . . . . . 137

Radical journals deny that the election had been carried under false pretenses. . . . . . . . . 138

Failure of the Copperhead and Conservative coalition. . . . . . 139

The New York City Charter Election . . . . I I0

Judge Richard Kelly ws. Richard B. Connolly . . . . . . I4I

Interest in election slight. Tammany wins easily . . . . . 142

\section{CHAPTER VI}

The Senatorial Election of 1867

All eyes centered on the Republican legislature . . . . . . . . 144

Horace Greeley. Charles J. Folger . . . . . . . . . . . . . . . . 144

Senator Ira Harris, Roscoe Conkling . . . . . . . . . . . . 145

Noah Davis, Lyman Tremaine, George William Curtis . . . . . 146

Greeley's general amnesty statement kills his candidacy. . . . . . I47

Odds in Davis' favor . . . . . . . . . . . . 148

Fenton's attitude puzzles many . . . . . . . . . . . 149

Friends of Alvord and Bruce desire revenge on Fenton. . . . . . 150

Nominations made . . . . . . . . . . . . . 15 I

Conkling elected . . . . . . . . . . . . . . . 152

The Democratic caucus . . . . . . . . . . . . . . . 153

Conkling's rise meteoric. . . . . . . . . . . . . . I 154

The World foresees formation of a Ring in Republican party . . . I 55

The Trubue commends Conkling. . . . . . . . . . . . . 155

Up-State editorial interest in election not marked . . . . . . . 157

Conkling's maiden speech in the Senate....... . . . . I 158

\section{CHAPTER VII}

Tile Conventions of 1867

The Union Republican State Convention. . . . . . . . . . . . I59

Conkling and Fenton contend for control of convention . . . . 159

Rival delegations from New York City. . . . . . . . . . . . . 160

Movement for complete change in ticket. . . . . . . . . 161

The Times and Commercial Advertiser condemn convention . . 162

Weed blames Greeley for unwise course of convention . . . 163

Committee appointed to investigate 23rd St. delegation's claims. I64

Irregularities on both sides . . . . . . . . . . . . . . . . . . I64

Roscoe Conkling's address. . . . . . . . . . . . 165

Nomination. . . . . . . . . . . . . 166 
Weed condemns convention: comments of the World and the Tribune. . . . . . . . . . . . . . 107 Platform supports Congress, throws sop to temperance element. 168 Raymond pours oil upon the waters . . . . . . . . . I69 Radical papers in western part of State uniformly approve convention

Democratic organs considered new ticket a confession of guilt. . 171 State Temperance Convention . . . . . . . . . . I71 The Democratic State Convention..... . . . . 172

Seymour still too strong for Hoffman . . . . . . . . . 172 The Herald admires Seymour's speech. ‥ . 173 Tammany rewards Mozart Hall _. . . . 175 Seymour rules, John McKeon denounces platform . . . . . ${ }_{176}$ Platform a pledge to redeem New York from corruption . . . 177 Strife over nominations not keen . . . . . . . . 178 Weed gives a cautious approval of the convention. . . . 180 Greeley's editorial on silence. . . . . . . . . . . . . I8I The up-State Democratic editorials ring true . . . . . . 182

\section{CHAPTER VIII}

\section{The Democratic Reaction}

Radicals attempt to throw burden of proof . . . . . . . 184

Greeley repudiates Radical resolution on excise ...... I 185

Democrats count on Radical excesses _. . . . . . . 186

Radicals explain Democratic success in October elections. . . . 187

Raymond and Greeley caution Radicals . . . . . . . . 188

Fernando Wood makes his plans. . . . . . . . . . . . 189

William M. Evarts sums up the situation. . . . . . . . . I90

The Sun and the World warn Democrats. . . . . . . . . . I9I

Democratic caution aids their cause . . . . . . . . . ${ }_{192}$

The Presidential canvass for the following year. . . . . . . 192

Mid-campaign finds both parties in general apathy . . . . . . 193

State Convention of Brewers . . . . . . . . . . . . 194

Merry internecine war between Conservative and Radical factions

of Republicans ...... . . . . . . . . 195

Politics of New York City complex . . . . . . . . . . 196

Nominations in New York City . . . . . . . . . . . . 197

Venality of Radical legislature given airing . . . . . . . . . . 198

Senator Wolcott J. Humphrey's case . . . . . . . . . . . . 198

Case of Auditor Benton. . . . . . . . . . . . . . . . 199

Counter charges of Radicals against Tweed Ring. . . . . . . . 200

Conservatism of Radical up-State editors. . . . . . . . . . 201 
PAGE

Question of the Constitutional Convention's adjournment. . . . 202

Radical corruption in western part of State. . . . . . . . . . 203

Excise movement . . . . . . . . . . . . . . . . . 204

Democratic family troubles . . . . . . . . . . . . . 205

Homer A. Nelson bids for the Temperance vote. . . . . . . 206

Result-Democratic landslide . . . . . . . . . . . . 207

Greeley blames New York City papers. . . . . . . . . . . . . . 209

Radical organs up-State explain. . . . . . . . . . . . . . . 209

Weed's verdict . . . . . . . . . . . . . 2 2 ro

The World admits Republican aid . . . . . . . . . . . . . 2 II

\section{CHAPTER IX}

The Constitutional Convention of i867

Composition . . . . . . . . . . . . . . 2 2 2

High character of delegates. . . . . . . . . . . . . 213

The Judiciary Article . . . . . . . . . . . . . . . . . . . . . $2 \mathbf{2}_{4}$

Faults in the present system. . . . . . . . . . . . . 214

Court of Appeals receives most serious attention . . . . . . 2 215

Debate on Judiciary article. . . . . . . . . . . . . . 216

Judge Daly's résumé . . . . . . . . . . . . . . . . . . . . . 218

William M. Evarts' plea for the principle of good behavior . . . 220

Defeat of amendment for tenure during good behavior . . . . 222

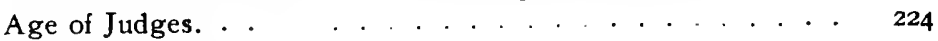

Commission of Appeals . . . . . . . . . . . . . . . . . 225

The Supreme Court, majority plan. . . . . . . . . . . . . 225

The minority plan. . . . . . . . . . . . . . . . . 226

Other proposals. . . . . . . . . . . . . . . . . . . . . . . 227

Convention changes majority plan to election by districts. . . 227

Summary in regard to the Supreme Court . . . . . . . . . . 228

Minor courts . . . . . . . . . . . . . . . . . . . . 229

Surrogates' Courts . . . . . . . . . . . . . . . 230

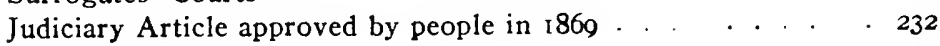

Suffrage. . . . . . . . . . . . . . . . 233

Existing standard . . . . . . . . . . . . . . . . . . 234

Committee favors change in the time of residence requirement. 235

Educational qualifications refused . . . . . . . . . 236

Woman suffrage . . . . . . . . . . . . . 236

Negro suffrage . . . . . . . . . . . . . . . . 237

The Bill of Rights . . . . . . . . . . . . . . . . 238

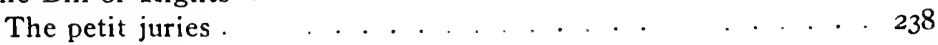

The Legislature. . . . . . . . . . . . . . . . . . . . 239

New organization of senate and assembly districts . . . . . 240

Report of committee on the powers and duties of the legislature. $24 \mathrm{I}$

Convention accepts Court of Clains . . . . . . . . . . . . . 24I 
The Executive

Radical change in veto power proposed. . ' . '

Radical change in veto power proposed. . . . . . . . . 243

Miscellaneous. . . . . . . . . . . . . . 243

Consideration of canal questions. . . . . . . . $\quad-44$

No important changes educationally . . . . . . . . . . . . -45

Report of committee on official corruption .. . . . . . . 2 . . . . . .

State charities receive exhaustive attention. . . . . . . 247

Recommendations of the committee on subnission . $\quad 248$

Résumé. . . . . . . . . . . . 248

Submission . . . . . . . . . . . . . . . . 254

Questions regarding submission ... . . . . . . . . 255

People reject the proposed constitution, except judiciary article . 256

Political aspects of the convention . . . . . . . . . . 256

Great political power brought to bear upon convention . . . 256

Unpopularity of the proposed constitution . . . . . . . . 258

Greeley's attitude hurt the convention . . . . . . . . . . . . 259

Accusations of Democrats over adjournment . . . . . . . . 260

The Herald uncompromising in its criticism . . . . . . . . . 26r

Action of the Union Republican party on negro suffrage a severe

handicap . . . . . . . . . . . . . . . . 262

The Nation gives two causes for failure of convention . . . . 263

Up-State Radical papers minimize the Democratic attacks . . . 264

Revised constitution center of attack in campaign of $1869 .+265$

Summary. . . . . . . . . . . . . . . . 266

\section{CHAPTER X}

The Alliance of Wall. Street and the Legislature

Introduction . . . . . . . . . . . . . . . . 267

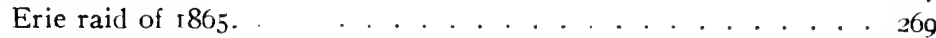

Drew's harvest. . . . . . . . . . . . . . . . 270

An interlude . . . . . . . . . . . . . . . 272

Vanderbilt reopens hostilities . . . . . . . . . . . . 272

The crisis. . . . . . . . . . 273

March 10, 1868. . . . . . . . . . . 274 274

Fisk seizes shares . . . . . . . . . . . . . . . . . 276

Injunction of universal application . . . . . . . . . 277

New York legislature takes cognizance of the Erie War . . 279

Legislative committee investigates . . . . . . . . . . . . . 280

Two reports submitted. . . . . . . . . . . . . . . . . 281

Senator Mattoon's secret visits . . . . . . . . . . 282

Bill to legalize recent issue of Erie stock. . . . . . . . . . . 283

Gould goes to Albany . . . . . . . . . . . . . . . . . . 284

Gould's arrest. . . . . . . . . . . . . . . . . 284 
Mr. Glenn charges that Erie Rill was bought. .

Glenn demands that Mr. Frear be relieved from committee.. . . 287

Testimony of Glenn.

Mark M. Lewis testifies.

Evidence of Assemblymen Ray and Ranney . . . . . . . . . . 290

Committee finds the charges against Frear unjustified. . . . 291

Legislature whitewashed. . . . . . . . . . . . . 292

Vanderbilt withdraws . . . . . . . . . . . . . 293

Peace negotiated . . . . . . . . . . . . . . . 294

Gould and Fisk forced to acquiesce in settlement . . . . . . . . 295

Fruits of the harvest. . . . . . . . . . . . . 296

Justice Barnard fines directors for contempt . . . . . . . . 297

Aim of chapter......................

Senator Hale's Committee. . . . . . . . . 298

Mr. Thompson's testimony . . . . . . . . . . . . . 299

Luther Caldwell testifies. . . . . . . . . 300

Committee makes savage attack on the press........ 30I

Legislature again whitewashed. 302

CHAPTER XI

New York and the Presidential Nominations in 1868

The Republican State Nominating Convention . . . . . . . . . 303

Fenton controls New York City contest . . . . . . . . 304

The Republican National Convention . . . . . . . . . . 309

Unfavorable auspices for the convention . . . . . . . . . 309

Grant's name accepted without serious question ...... . 3I0

New York delegation centers attention of delegates. . . . . 310

New York delegation not a unit . . . . . . . . . . . . 310

New York forces the admittance of the Southern votes. . 3 311

Lyman Tremaine allays excitement . . . . . . . . . . 3I2

Moderates win point in platform. . . . . . . . . . . 312

Grant nominated . . . . . . . . . . . . . . 312

Fenton among leaders on ballot for vice-president . . . . . 313

Fenton loses to Colfax. . . . . . . . . . . . . 313

Platform a compromise, advantage with Radicals. . . . . . 313

Rapid changes in sentiment of Republicans. . . . . . . . . 314

Henry Raymond open to conviction on convention. . . . . . 315

Greeley comments. . . . . . . . . . . . . 315

The World points out weaknesses . . . . . . . . . . 316

Grant stronger than his party . . . . . . . . . 3I7 
UP-State papers follow the New York journals. PAG

Outlook does not appear roseate to Ellis Roberts. . . . . . . 319

Albany Evening Journal unrestrained in its enthusiasm . . . 320

Comment of the Utica Daily Observer. . . . . . . . . . 320

The Democratic State Nominating Convention . . . . . . 321

Seymour's address. . . . . . . . . . . . . 322

Delegates. . . . . . . . . . . . . . 323

Take Seymour's cue. . . . . . . . . . . . . . 324

Platform . . . . . . . . . . . . . . 324

The Democratic National Convention . . . . . . . . . 325

Merits of Chief Justice Chase's candidacy. . . . . . . . . . 325

Tilton and Dana favor Chase . . . . . . . . . . 326

Bennett strongly advocates Chase . . . . . . . . . . 327

Seymour's address of June $25^{\text {th }}$. . . . . . . . . . . . . . 328

Republican papers do not believe Seymour . . . . . . . . 329

Democratic situation grave . . . . . . . . . . . 330

Mention of Admiral Farragut and Francis P. Blair . . . . . 33I

Other names used to benefit Chase, Seymour and Pendleton . . 332

New Democratic sentiment . . . . . . . . . . 333

August Belmont calls the Convention to order . . . . . . . . 334

The Herald and the Sun advocate Chase over Sunday. . . . . . 335

Seymour's address discloses nothing new. . . . . . . . . . 337

Sanford E. Church to be played against Chase . . . . . 338

The Herald's contempt for Church. . . . . . . . . . 338

Platform adopted . . . . . . . . . . . . . 339

Seymour declines to run. . . . . . . . . . 34

Convention stampeded for Seymour . . . . . . . . . $34 \mathrm{I}$

General Francis P. Blair receives second place. . . . . . . . 34 I

Behind the scenes. . . . . . . . . . . . . . 342

Bennett inconsolable over his failure to nominate Chase. . . . 344

The logic of the World . . . . . . . . . . . . . . . 345

Dana pronounces Seymour a fair representative of Democracy. . 545

Greeley outdoes himself . . . . . . . . . . . . . 347

Democratic State journals unite over candidate and platform . . 349

\section{CHAPTER XII}

\section{The State Conventions of New York in 1868}

The Republican State Nominating Convention . . . . . . . 351

Delegates come uninstructed for most part . . . . . . . 35I

The New York feud . . . . . . . . . . 352

General John Cochrane made permanent president . . . . . . 353

Greeley led into ambuscade . . . . . . . . . . . . 354 
Platform echo of Chicago platform. . . . . . . . . . 356

Editorial opinion stereotyped. . . . . . . . . . . . . . . . 357

Greeley hides his wound. . . . . . . . . . . . . . . . . 357

The Evening Post gives qualified assent on Griswold . . . . . . 358

The Commercial Advertiser strong for Griswold . . . . . . . 358

The World takes but slight notice of convention . . . . . . . 359

The Democratic State Nominating Convention. . . . . . . . . 360

Vermont elections dampen ardor of delegates. . . . . . . . 360

Hoffman zis. Murphy . . . . . . . . . . . . . 361

Robert Earl permanent president . . . . . . . . . $\quad 362$

Murphy withdraws in favor of Tammany. . . . . . . . 362

Judge Morris breaks Tammany's slate . _ . . . . . . . . 363

Explanation of the Kings County $v s$. Tammany incident . . . . 364

Platform a comment on Democratic National Platform . . . 366

Electoral ticket . . . . . . . . . . . . . . 367

The Commercial Advertiser and the World pay Murphy tribute 368

The Sun's pleasantries. . . . . . . . . . . . . . . . . . . 369

Hoffman Democrats' strongest man . . . . . . . . . . . . . 370

\section{CHAPTER XIII}

\section{The Presidential Campaign of 1868}

Campaign does not open with éclat . . . . . 371

Republicans base claims for victory on Grant's popularity . . . 372

Usual exchange of civilities $\quad . \quad . \quad . \quad 372$

Keynote of campaign _. . . . . . . . 373

Griswold's connection with the Monitor . . . 374

Hoff man's opening address . . . 376

Financial rebuttal of the Times. . . . . . . . . . . . . 376

Maine elections indicate result . . . . . . . . . . . . . . . . . . 377

Republicans redouble activities in State. . . . . . . . . 378

Special appeals to Irish and German elements by Republicans. . . 378

October elections lead the World to demand change in ticket . . 381

No one found to take Seymour's and Blair's places . . . . . 382

Blair invades East to defend himself $\quad . . . . \quad 383$

Democratic State Committee's address. . . . . . . . . . 384

Greeley's final broadside. . . . . . . . . . . . . . 385

Conkling returns from West, begins active campaign. . . . . 386

Albany Evening Journal sums up issues . . . . . . . . . . . . . 388

Roberts very conservative . . . . . . . . . . . . . . . . . . . 388

Seward's address at Auburn . . . . . . . . . . . . . . . 390

Presentment of gigantic frauds on eve of election. . . . . . . 391 
CHAPTER XIV

\section{Tweed Carries tue State by Fraud}

Seymour and Hoffman victors in the State. . . . . . . . . . 392

The secret circular . . . . . . . . . . . . . . . . . . . 393

Charges of fraud against Tammany. . . . . . . . . . . 394

Congressional committee appointed to investigate . . . . . . . . 395

Majority report finds gross frauds in election . . . . . . . . . . . 396

Evidence of criminal intent in high judicial places . . . . . . . 397

Tammany naturalization committee. . . . . . . . . . . . . . 398

Sheriff O'Brien appoints 2,000 toughs as deputies. . . . . . . . 399

Minority report finds frauds exaggerated, Republicans guilty . . 400

Commercial Advertiser blames Republicans for lack of organization. 400

Greeley consoles Seymour .. . . . . . . . . . . . 402

The World praises Seymour for moderate tone of campaign. . . 403

The New York City Charter election of r868 . . . . . . . . . 404

A. Oakey Hall and Frederick A. Conkling candidates for Mayor. 404 Mozart Hall fails to agree with Tammany on O'Gorman . . . . 405

Lack of interest in Charter Election. . . . . . . . . . . . 405

Tammany wins without effort. . . . . . . . . . . 405

Conclusion . . . . . 407 413

Index. . . . . . . . . . . 425-447 



\section{CHAPTER I}

\section{INTRODUCTION}

In the rise of the Federalist Party and its transformation into the States Rights Party; in the development of the Anti-Federalist or Jeffersonian Republican Party and the resultant transformation into the Democracy; in the organization of the National Republicans in 1824, also, of their powerful rival the Jacksonian Democracy; in the rise of the Whigs in 1834 , and of the Republican Party in 1854 ; as well as in the lesser party movements, New York played a leading rôle due to its great wealth, population, and dominant position socially and industrially. This is especially true of New York in the constant party disintegration, re-organizations and new alignments during the period from 1852 to 1868 . The factors which produced these changes were generally active in New York. The confusing tangle of party names in the period immediately at the close of the Rebellion gives evidence of these changes.

In 1865 the Civil War had been crushed, but few could clearly foresee the political results. During the course of the War the administration at Washington had not only to conduct hostilities, but also to maintain its status quo politically in the northern States in order that it might carry the War to a successful finish. Lincoln and his administration realized the importance of retaining the support of New York, but in few if any of the northern commonwealths was the task of maintaining support harder than in New York. Only during a few 23] 
months following the attack on Fort Sumter and for a short period in the early part of 1862 did New York present a united front politically. For the remainde: of the Civil War period the politics of the State presented a continuous kaleidoscopic succession of party dissensions which engendered a heat seldom exceeded.

The political situation in New York State throughout the War presented two chief features: ${ }^{x}$ first, the fact that politics in the State turned entirely upon questions of national importance; and second, the active feud between the followers of Thurlow Weed, the founder of the Albany Evening Journal, and those of Horace Greeley, the editor of the New York Tribune. Weed, who was an acknowledged power in the State, was incessantly attacked by Greeley. The latter's followers grew into a powerful faction in the State both prior and subsequent to the transformation of the Republican Party into the Union Party. This factional fight developed radical and conservative wings in the Union Party within the State. The Greeley, or radical, wing probably attained its greatest power during the War at the Republican-Union State Convention of $\mathrm{r} 862$, which nominated General James S. Wadsworth for Governor. But upon Horatio Seymour's defeat of Greeley's candidate, the conservative wing under Weed again seems to have been on top at least by the following spring. It would appear that Weed, rather than Greeley, was largely responsible for the split in the administration forces during the Civil War. Certainly Weed's constant use of expediency tended to promote division and kept Weed from rising above the plane of a politician.

${ }^{1}$ For a detailed treatment of politics in New York State from 18601865, see Brummer, Political History of New York State During the Period of the Civil War. 
By the joint action of the Republican State Convention and of the Peoples State Convention in producing a Union ticket in $\mathrm{I} 86 \mathrm{I}$, and through the Republican-Union State Convention in 1862, a movement was developed, which, by an absorption of War Democrats, caused the Republicans to drop their name and to adopt the more appropriate term Union, as a party title. The designation Union was used until after the War. As the majority of Democrats refused to enter the Union Party, and as they logically began to act as obstructionists to the national administration, at a time when it was engaged in a life and death struggle, the Democracy of New York, although claiming an intention to uphold the war policy, naturally found itself approaching the position of the Copperheads.

It was of common belief during the period of the War that the unpatriotic course of the Democrats, in attempting to block an administration trying to preserve the unity of the nation, would lead to their downfall, as did a similar course on the part of the Federalists during the War of 1812 and in the Hartford Convention. That the Democrats of New York came out of the War period without apparent loss of strength may be explained by the fact that the radicals in the Democratic ranks, such as Fernando Wood, were largely restrained by the more moderate men. Dean Richmond and Sanford E. Church were in favor of prosecuting the War. Governor Seymour proved a cautious advisor. Further, the hostile sentiment stirred up among the foreigners in New York City over the draft, which culminated in the draft riot of July, $\mathrm{s} 863$. was a potent factor in enabling the Democrats to retain their strength in the State. This hostility to the draft among the foreign element was fanned into a flame by the untiring activity 
of the Copperheads, and was utilized by Tammany Hall at the close of the War to enable the Democracy, in spite of its disloyal course throughout the War, to present a solid and aggressive front to the rest of the State.

It appears clear that not only the radicals in the Democratic ranks, but also the party leaders and press in general aided in arousing resistance to the enforcement of the draft. For this, Democracy paid dearly, as the Unionists regained control of the State in the elections of 1863 and continued their control in the elections of the following year. However, in 1864 Lincoln carried the State by less than 7,000 and Reuben E. Fenton, for Governor, by less than 9,000. These small majorities bring into strong relief the dissensions in the Unionist ranks and the entrenched position of the Democrats in local offices in the southeastern counties of the State.

In 1865 we find a political situation in New York State much changed from that which existed at the opening of the Rebellion. The furnace fire of the War had fused certain of the old party splits. Those who advertised themselves as veterans of third parties had disappeared; the division between the followers of Douglas and Breckinridge showed nothing but the scar; the terms "hards" and "softs," relative to the brands of Democratic vintage, were no longer heard; the Regency was forced to contend for its laurels with Tammany, and dissensions in Mozart Hall had given Tammany Hall opportunity to extend its control. The influence of Fernando Wood had been greatly diminished. Tammany Hall under the guidance of William $M$. Tweed and Peter B. Sweeny now became a prominent factor in the Democratic councils of the State. Dean Richmond continued to hold his ascendency in the Democratic councils, and Horatio Seymour's influence in the party was on the increase. 
Among the Unionists in I 865 the feud between the Weed faction and the anti-Weed, or Greeley, faction still flourished. However, with the close of the War and the consequent rise of questions concerning Reconstruction, a new alignment of issues offered fresh food to nourish differences between these factions. In the rise of Fenton, backed by the radical faction, the power of Weed was broken. Nevertheless, Weed was still a power to be reckoned with. William $\mathrm{H}$. Seward, although he was devoting his entire energies to a successful administration of the Department of State, was still looked upon as the leader of the conservative faction of the Union Party in New York. Weed doubtless still consulted him, but Seward perceptibly dropped his active connection with State politics at the close of the War.

On the other hand a group of men who had not assumed great prominence during the period of the Rebellion now advanced to positions of leadership in the politics of the State. Henry J. Raymond, the editor of the New York Times, entered Congress in 1865 and as a friend of Seward and Weed he was able to stand forth at once as the champion of the administration. Doubtless his connection with the New York Times was a coign of vantage. In 1865 Governor Fenton and Roscoe Conkling had not risen to their later prominence. Moreover, the radical wing of the Union Party was still under the guidance of Horace Greeley. But the way was being prepared for the overthrow of Seward, Weed and Raymond, as supporters of President Johnson's policy. and the dominance of the machine controlled by Reuben E. Fenton, which in turn gave way to the superior generalship of Roscoe Conkling.

It is our special province to discuss the political situation in New York State from 1865 to I869, or during 
the period of President Johnson's administration. This period corresponds with the early Reconstruction period in the South. Hence it will be the aim to keep the national political situation constantly in view as a background for State activities. However, chief attention will be directed to a study of the factors which in the Unionist, or Republican Party, ${ }^{1}$ brought about the downfall of Seward, Weed and Raymond; the temporary ascendency of Fenton; the rise of Conkling; the failure of the Radicals to apply their doctrines on negro suffrage to the State; and the loss of prestige for the Radicals in the legislature resulting from the disclosures of venality in connection with the Erie War. The above grouping of points to which attention will be especially directed in the politics of the Republican Party, will be used to disclose the attempts of the Democratic Party to rehabilitate itself, and to contrast its steady advance in power with a corresponding weakening, due to corruption, in the Republican control of the State. Although questions of national prominence appeared to hold a leading place in the campaigns of the period, local rather than national issues, together with questionable methods, proved to be the factors which enabled the Democrats to coalesce and elect John T. Hoffman, as Governor when for President, Grant carried the State. In view of Democracy's course from 1860 to 1865 , it is not strange that this transitional period, corresponding to the turbulent early Reconstruction period in the South, should present the best opportunity to ascertain the causes leading to the period of Democratic control in New York that began with I 869 .

'The latter name was generally reverted to shortly after the War. 


\section{CHAPTER II}

Social and Economic Survey of New York at the Close of the Civil. War

The conditions in New York State during the year of I 865 made manifest its potential strength and resources. Though heavy demands had been laid upon the State through the war, its prosperity continued uninterrupted. New York, owing to its increased prosperity, was singularly open to the manipulations of unprincipled politicians. The fact that a large proportion of its men of character had been sacrificed in the war, or were occupied largely with national duties, gave rein to opportunity for the self-seekers. It was during this period that the ground work was established for the iniquitous plans of those who made the New York City and State administrations a by-word.

New York may be prond of its war record. The total number of men sent to the field from April i 5, I86 I to December 3 I, I 864 was $437,701 .^{1}$ The number furnished in 1865 until the end of the war brings the aggregate number of men furnished under all calls to $464,70 \mathrm{I}$. New York led all of the Union States in the number of men it sent to the front. Pennsylvania was its next competitor with a grand total of $366,326 .^{2}$ The State disbursed in bounties alone, principal and interest \$43,-

'Adjutant-General's Report, 1865, p. 33.

"Report of the Committee on Voluntering of the County of N'ze" York. Document I2, vol. i, p. 701 . 
270,337.47. New York City furnished 148,676 men for various terms. ${ }^{2}$ This number, considering the fact that New York was a comparatively small city, is large.

In 1865 , New York City was advancing rapidly to the position it now occupies. Already, the increase of the cosmopolitan elements ${ }^{3}$ among its citizens gave cause for serious thought. This was evinced in the incorporation of the "Home Building Company" by a group of wealthy New York citizens, in an effort to alleviate the tenement congestion. The purpose of the company was to erect modern houses in Williamsburg, near the ferry. These were to be sold at cost, or to be rented at a simple interest on the outlay.4 The Nation summed up the popular notion of the laissez-faire attitude which New York has been so prone to assume, when it said:

There is ... dismal outcry about houses ... in New York. The scarcity is great and the ordinary law of demand and supply does not seem to work. We are surprised there has been as yet no outcry raised against the 'speculators' for bringing the price of houses up. ${ }^{5}$

'Messages from the Governors, voi. viii, p. I4I. For a sketch of the origin of the bounty debt, see Annual Message, 1863, note 6; also ibid., vol. v, pp. $454,571,609$.

"Report of the Committee on Volunteering, op. cit., p. 669.

${ }^{3}$ The following statistics are based upon the United States Census of I860, which found the population of New York City at that date to be 813,669 . Of this number 429,952 were born in the United States. The remainder, 383,717 , were born in foreign countries of forty-two different nationalities. There were 3,272 marriages, 6,424 births, and 25 , I 66 deaths in the city yearly. The city taxes amounted to $\$ 18,000,000$. Public amusements drew from the people $\$ 2,000,000$ yearly. The police required $\$ 2,000,000$ for their support. The average number of immigrants landing per month at Castle Garden was 17,000. City Mission and Tract Society Reports, I865-7, p. I31.

The Nation, vol. i-ii, 1865, p. I63.

'The Nation, 1865, p. 34 . 
These congested conditions in New York City were further aggravated in 1865 , by the presence of a large number of discharged soldiers. New York City was a natural center of gravity for them and their presence caused great annoyance to the citizens and merchants of the city. On Friday August I I, 1865, between three and four hundred soldiers paraded the streets of New York in order to demonstrate the fact that they needed employment. ${ }^{r}$ They considered that the people had treated them unfairly. The Nation pointedly remarked, that

many of these gentlemen are a little over particular about the kind of situation they will take and display an unreasonable fondness for city life. Anywhere outside of New York they can find work in abundance, and it is scarcely fair to blame the merchants here for the overcrowding of the labor market in this particular spot wrought by the laborers themselves.

Moreover, the sanitary ${ }^{3}$ condition of New York City at this period was in dire need of improvement. A movement for reform in this direction was instituted in I 865 by the Citizens Committee of New York. ${ }^{4}$ This

${ }^{1}$ New York Times, August I I, 1865.

${ }^{2}$ The Nation, vol. i-ii, I865, p. 194.

${ }^{3}$ A sanitary survey and census of New York City was completed in Dec., 1864. The board found that 495,592 persons in II I, oo families were living in 15,319 tenement houses and cellars. This made an average of 7.25 families or 32.37 persons to a house. The investigators found further, that of the 15,309 tenement houses, 3,932, in which 100,675 persons were housed, had absolutely no sewer connections. Davenport, Population of New York, p. 4.

"The necessity for a thorough sanitary house-cleaning was thrust upon New York City, when it faced danger from an epidemic of Asiatic cholera in the fall of 1865 . Cases of the disease first arrived upon the steamship Atalanta, November 2, 1865. The plague, at this time, had spread from eastern Asia through western Europe. The Commission- 
was the most systematic and scientific endeavor to improve the hygiene of the City ever attempted. The Council of Hygiene, which was composed entirely of physicians, was a direct attack upon the City's sanitary administration.' The total number of deaths during the year $1863,{ }^{2}$ amounting to $25,196,{ }^{3}$ made a death rate greater than that of any other large city in the world at that time. The causes of the various prevalent diseases were investigated; the construction of tenements. sewerage, stables $e f c$. was severely criticised; and remedies were suggested.

In order to understand the origin and power of the

ers of Quarantine found themselves entirely unprovided with places to receive the patients, or places to segregate suspects. Their funds had been spent for other purposes. Upon request of the board, Governor Fenton issued a proclamation of impending pestilence. He advised the commissioners to assume the responsibility of incurring such liabilities as were needed to meet the peril, and to rely upon the legislature to ratify their action. Before all needful precautions had been taken, cases broke out in the city. A building at Five Points was secured as a House of Refuge. The Barracks, situated on the Battery, were fitted up for hospital purposes. Arrangements were made to establish another hospital in Harlem, in case of need. A central Bureau for Disinfectants was opened in Mulberry Street. The streets werc cleaned, and endeavors were made to destroy all foul odors. Tenement houses werc depopulated and cleaned. These measures proved effective in stopping the plague. The high-water mark was reached on August 5, 1866, when twenty-nine cases were reported. Publications of the Citizens' Association, pamph. 18, p. 25. Appleton's Annual Cyclopedia, I865. p. 613. New York Evening Post. Nov. 4. 1865. New York Herald, August I4, 1866.

'Report of the Council of Hygiene and Public Health of the Citizens Association of New York upon the sanitary condition of the city, I865. This report is important in that it took the initial step in the reclamatory process through which New York has been lifted to a more wholesome condition.

2 The report only made a study of statistics to 1863 .

'Ibid. (Report), p. 40. 
"Ring" development in New York City, it is important to have, besides the facts already stated, some conception of the low status of life in certain portions of the City. The party boss early saw the political value of food, picnics and entertainments, in his endeavor to herd the vote of these quarters. The conditions in certain parts of New York City, even today far from ideal, were infinitely worse in I865. A party of investigators pictured the life in the low sections of the Fourth and Sixth Wards as follows :

We first visited some houses in Fisher's Alley, ... In these houses we found a family in each room, some with half a dozen lodgers in addition. Children swarmed in the dark passages, on the broken stairs and in the noisome back yards. The walls were cracked, the ceilings leaky, the broken floors mended in some places with barrel staves nailed over the holes and the windows so patched and dirty as to exclude much of the light. ${ }^{2}$

The owners of these barracks and cellars had become conscious of danger from a new Board of Health which had been appointed ten days previous to the publication of this report. The investigators state that

fifteen hundred loads of filth had been already removed from the Fourth Ward, and in many courts and alleys only a dirty tide mark on the walls remains to tell of their recent condition. Some streets [Cedar Street for instance] were still ridged up to the height of nearly two feet for their entire length. ${ }^{3}$

${ }^{1}$ Talcott Williams, Tammany Hall (In Historic New York, 1899), vol. ii, pp. 33-79.

"The Nation, vol. i-ii, p. 332.

${ }^{3}$ The Nation, vol. i-ii, p. 332. The report continues: "We next descended into a number of lodging-cellars, not more than one in five of 
Is there much room for wonder at the power of the ward boss, when one considers the allurements he offered, as a momentary relief from these conditions? "The filthy condition of the city entailed a fearful sacrifice of life," says Gustavus Myers, "the average deaths yearly being no less than thirty-three in one thousand. Nearly all the 220 health wardens and special inspectors under Francis I. A. Boole, the city inspector, were illiterate and unfit." . One of the above health wardens, when asked by the Senate committee of investigation the meaning of the term "hygienics," answered: "I suppose it is some odor that arises from the stagnant water." " Speaking of the condition of New York City, Andrew D. White, who was on the Senate committee, said: "The facts which I brought out were sufficient to condemn the whole existing system twenty times over." 3 The sordid congestion in New York City, together with Tammany's

which was lighted, except perhaps by a window in the upper part of the room. Dark, damp, unventilated and so cramped that we were frequently unable to stand upright, these dens paid a rent of from nine to sixteen dollars a month. Although we were always careful to leave the door open wherever we entered, a few minutes in such an atmosphere were enough to produce oppression of the lungs and a disagreeable taste in the mouth. What must it be towards morning, after a dozen men and women have been sleeping there for hours?. . . Turning into East Gotham Court, we found a block of tenement houses, upwards of one hundred and fifty feet long, standing at right angles to the street. . The narrow alley-way which gave access to these dwellings was pierced, at regular intervals, with open gratings, down which we looked into a continuous open sewer, the common sink of all. It was fortunate for us that the keen cold kept down its terrible exhalations."

${ }^{1}$ Gustavus Myers, A History of Tammany Hall (New York, 190I), p. 248.

'Senate Documents, 1865, vol. ii, no. 38, p. 467 .

'Autobiography of Andrew D. White (New York, 1905), vol. i, p. 126. Cf. Matthew Hale Smith, Sunshine and Shadow in New York (Hartford, Conn., I883), passim. 
ability to utilize this condition for its own ends, was the chief source of the power for Tammany Hall. Further, when one consiclers the fact that New York City has always counterbalanced the remainder of the State politically, it appears clear that this same condition was one of the chief sources of power for the Democratic Party in New York State.

Under the discussion of party campaigns it will be shown that the political control of the congested districts in the cities of the State was closely related to the liquor traffic. In each campaign and especially in 1867 , the influence of this element was a determining factor. New York City alone in I865, it is estimated, had I0,000 places where intoxicating liquors were sold, with gross receipts annually of $\$ 5,000,000$, assuming an average of $\$ 500$ to each place. ${ }^{1}$ Co-equal as a field for police graft and political jobbery, we find that a low estimate of the value of the real and personal property invested for immoral purposes in New York City was placed at \$5,000,000. ${ }^{2}$ Further, it was estimated that the amount of money spent in houses of assignation, together with the sums required for the expenses of criminal and humane institutions resulting from the social evil, must total at not less than an additional $\$ 5,000,000 .^{3}$

Industrially, the condition of New York State in 1865 was strong. It is true that between $186 \mathrm{I}-5$ there was a period of depression in shipping, due to the use of American vessels for war purposes, the occupation of

'City Mission and Tract Society Reports, 1865, p. 132.

${ }^{2}$ Ibid.; from police investigations and medical testimony it was calculated that there were 7,500 prostitutes and 2,500 other women who frequented houses of ill fame. Hence a mean total of 10,000 .

${ }^{3}$ Ibid.; allowing for a natural prejudice, these reports are considered fairly accurate. 
northern manufacturers in making war supplies to be used at home, and a lack of faith in American financial integrity on the part of foreign markets induced by the stress of war. The American shipping of the Port of New York, used in connection with the foreign trade, declined from $1,618,258$ tons in 1861 to 774,459 tons in I865. ${ }^{.}$The movement in New York reflected the larger movement throughout the country between the years I 86 I to I $865^{\circ}{ }^{2}$ For the United States the aggregate tonnage, inclusive of steam vessels, was $5,539.8$ I 3 tons in I $86 \mathrm{I}$. This was reduced in 1865 to $4,986,8$ I 3 tons. ${ }^{3}$ The tonnage in use for foreign trade dropped from 2,642,000 tons in 1860 , to $1,092,000$ tons in 1865 . This equals a reduction of sixty per cent. ${ }^{4}$ The gross annual value of exports and imoprts illustrates the same movement. In I 861 , the total value of the exports from the United States was $\$ 4$ IO $, 856,8$ I 8 , while that of imports was $\$ 352.075,535$. We find them reduced in 1865 to $\$ 336,697,123$ for the exports and to $\$ 234,339,8$ Io for the imports. ${ }^{5}$ Strikingly contrasted with its decline in shipping, the agriculture of New York flourished throughout the Rebel-

'Appleton's Annual Cyclopedia, 1865, p. 383.

${ }^{2} I b z d$., p. I83. A comparative summary of the clearances from the port of New York during the year I865 shows:

\begin{tabular}{|c|c|c|c|}
\hline American vessels & $\begin{array}{c}\text { No. vessels. } \\
990\end{array}$ & $\begin{array}{r}\text { Tonnage. } \\
664,096\end{array}$ & $\begin{array}{c}\text { Seamen. } \\
20,453\end{array}$ \\
\hline \multirow[t]{2}{*}{ Foreign vessels } & 3,202 & $\mathrm{I}, 495,226$ & 54,264 \\
\hline & 4,192 & 59,322 & 74,717 \\
\hline
\end{tabular}

Many vessels arrive from foreign ports which clear for a coastwise port. Hence, the clearances for foreign ports are generally fewer than the direct arrivals.

${ }^{3}$ Executive Documents, 1st Session, 39th Congress, Report of the Secretary of the Treasury, $1865, \mathrm{p} . \mathrm{I}-\mathrm{I} 46$, etc.

4 Ibid.

${ }^{5}$ Chamber of Commerce, N.Y., Annual Report. 1864-5, part ii, p. I2I. 
lion in spite of the large recruitment from the State. ${ }^{x}$ This was accounted for by the introduction of laborsaving machinery which compensated for the lack of men. ${ }^{2}$ With the exception of an unusual drought here and there through the summer of 1865 the year was favorable to crops. Peace immediately gave a new impulse to commerce in all sections of the country but especially in New York. With the growth in commerce came a like expansion in manufactures and agriculture.

The New York State Treasury receipts during the fiscal year which ended on September 30, I865, ircluding all funds except the canal fund, were $\$ 16,273,665 .^{3}$ The payments made on the account of all funds except the canal fund were $\$ 16,18_{3}, 095.98$. Hence, there was a balance in the treasury at the end of the fiscal year of $\$ 90,569.78$. The actual receipts from all sources were \$I I,912,936.48; the actual payments, which included the deficiency ${ }^{4}$ from the previous year, were $\$ 13.012,330.54$. This left a shortage on September 30, 1865, of \$1,I79,394.06. Had the City of New York paid its taxes before the end of the fiscal year, ${ }^{5}$ to the amount of $\$ 2,667,437.04$,

${ }^{1}$ Census of the State of New York, 1865, F. B. Hugh. The total assessed value of real estate in New York State in I865 was $\$ 1$, I60,848,745. Appleton's Ann. Cyclopedia, I865, p. 3. The New York wheat crop was larger than that of I864. In rye, the State was second to Pennsylvania in order of production. The barley crop (II,39I,286 bushels) was nearly two-fifths of the entire crop produced in the United States. New York State led in hay and oats. The hop crop of which New York contributed nine-tenths of the total yield, was small owing to lice.

${ }^{2}$ Messages from the Governors, Fenton, 1865, vol. v, p. 595.

3 New York Statc Comptroller's Report, January 2, I866, from which all the following figures are taken.

$+\$ 863,814.67$.

${ }^{5}$ The reason for New York City's delay in the payment of taxes due, arose from the fact that they were not collected until in the fall, which was nearly a year later than in the other counties. 
there would have been a balance in the State treasury of $\$ 2,758,006.82$. Likewise, in place of an arrearage in the general fund, there would have been a surplus of $\$ 1,488,042.98$.

The funded debt of the State was diminished to the extent of $\$ 8, \mathrm{I} 37,435.99$ from $\mathrm{r} 860$ to $\mathrm{I} 865$. The canal and general fund debts were $\$ 33,612,975.85$ on September 30,1860 ; at the end of five years, they were $\$ 25$,$475,539.86$. It appears obvious that at this rate the State would have been entirely free from debt in a few years. However, the large bounty loan, made in 1865 , which up to December Io, 1865 , amounted to $\$ 25,566$,ooo, ${ }^{x}$ placed the liquidation of the State's debt further in the future. The new bounty loan, with the canal and general fund debts, placed the total debt of the State on December ro, 1865 , at $\$ 51,041,539.86$.

The Canals showed receipts from tolls and other sources amounting to $\$ 3,577,465.45$. The disbursements were $\$ 1,927,373 \cdot 59$, which left a surplus reserve of $\$ 1,650,-$ o9I.86, to be paid into the sinking fund. These receipts, when compared with those of the preceding year, show a diminution of $\$ 763,800.07$. In Comptroller Robinson's report for December 30, I 865 , he called the attention of tax-payers to the fact that while the canal receipts "are rapidly diminishing, the expenses are still more rapidly increasing." After citing figures ${ }^{2}$ to illustrate his point, he continued: "These facts and figures are instructive

'New York State Comptroller's Report. Jan. 2, 1866.

"Ibid., pp. $27-8$. "In 1863 the receipts were $\$ 5, \mathrm{I} 18,50 \mathrm{I} .35$, and the payments for collection and ordinary repairs, $\$ 770.882 .52$. In I 865 the receipts were $\$ 3,577,465.45$, and the collection and ordinary repairs, $\$ 1,927,373.59$. In 1863 the surplus, to meet the requirements of the Constitution, was $\$ 4,347,618.83$, leaving a "remainder" of $\$ 98_{1}, 376$.1 7 . In 1865 the amount was but $\$ 1,650,091.86$, leaving a deficiency of $\$ 1,716,150.80$, to be provided by taxation. In 1863 the percentage, 
and are worthy of the attention of those who think that a state can manage the business of transportation better than private individuals, and who are proposing to build new canals, and to commence another enlargement of some old ones." .

Governor Fenton attempted to allay the unrest produced in certain quarters by the decrease in the canal revenue. He stated that this condition may have been brought about through the anxiety of producers to get their stock to market while prices were high. "Oftentimes their interest will be promoted by paying a higher rate of railroad transit, with a view of seeking a market which to-day is buoyant, and to-morrow may be depressed." 2 He expressed the belief that the canal income would revert to its normal condition.

The steam railroads of the State for the year ending September 30, I865, show earnings of $\$ 48,642,966 .^{3}$ Their disbursements, excluding that spent for construction, but inclusive of $\$ 155,000$, carried to the surplus fund, were $\$ 48,742,428$. Roads operated by horse power earned $\$ 5,948,657$. The payments of the latter roads amounted to $\$ 5,853,440$, including $\$ 226,283$ to the surplus fund.

An extensive change was made in the banking system of the State. On March 9. I865, the legislature passed

which the cost of maintenance of the canals bore to the amount of tolls, was but 15.33 ; in 1865 it rose to the enormous rate of 54.73 , being far greater than in any year since the canals went into operation. And this statement does not include the heavy payments for extraordinary repairs, which would make it much higher." .

${ }^{1}$ New York State Comptroller's Report, Jan. 2, I866, p. 29.

${ }^{2}$ Messages from the Governors, vol. v, p. 593.

'Appleton's Annual Cyclopedia, 1865, p. 612. 
an act ${ }^{x}$ to enable the State banks to transfer their organization and business to the national system without the necessity of formal dissolution, or the concomitant inconvenience of a dispersion of their capital and earnings.

Between March $9^{\text {th }}$ and September 3oth, 1865 , one hundred and seventy-three banks closed their business as State institutions and were converted into national banks. ${ }^{2}$ In addition to these, twenty banks had effected the change previous to the passage of the "Enabling Act." Thus, in the fiscal year of 1865 , one hundred and eighty-three banks were transferred with their wealth to the national system. ${ }^{3}$

The Superintendent of the Banking Department in his report transmitted to the legislature, March 3, I865, stated that the condition of the savings banks of the State was "one of great prosperity." 4 On the first of January, I865, there was due to depositors \$III,737,$763,^{5}$ an increase of nearly $\$ 18,000,000$ over the previous year. The total resources of the savings banks were \$I I9,34 I, 393.

'Annual Report of the Superintendent of the Banking Department of the State of New York, December 23, 1865, p. 2.

"Ibid.

${ }^{3}$ The extent of the change may be seen from the report of the Superintendent of the Banking Department, as follows: The capital invested in banking, under our State laws, on September 24, 1864, was $\$ 107,306$,948; on September $30,1865, \$ 20,436,970$; decrease during fiscal year, $\$ 86,869,978$. Greatest decrease in any previous year during the last ten years, \$I,951, 199 .

'Chamber of Commerce, New York State Annual Report, 1864-5, p. 87 .

${ }^{5} \mathrm{Ibid}$, the interest received was large, being $\$ 6,718,217$. This was more than six per cent. on the aggregate amount of deposits, and was attributed to investments in governmental securities. The interest on these was payable in gold, which had a high market value through the year. Hence, the interest was converted into currency at the high premium. 
In accordance with the requirements of the constitution, the State census was taken beginning the first Monday in June, I865. The population of New York State was found to be $3,831,977 .^{\text {. }}$ It was discovered that instead of the expected increase, the population had diminished to the extent of 48,958 from the census of I860. ${ }^{2}$ The decrease was still greater for New York City, which showed a loss of 87,283 , from the census of 1860. In his "Preliminary Report," ${ }^{3}$ Secretary Chauncey M. Depew said, in partial explanation of this phenomenon: "The extraordinary efforts made by New York in common with the loyal States, for the maintenance of the Union, could not fail of being shown in the results of the census. In every state where a census has been taken within the last year, this influence is shown, and if the aggregates are less than anticipated, it is only because we have under-estimated the effect of the cause." The papers of the State not in sympathy with

${ }^{1}$ Census of the State of New York, I865, p. 44.

${ }^{2}$ Ibid.

${ }^{3}$ Appleton's Ann. Cyclopedia, i865, p. 6I5. It is interesting to note the reasons given by towns for unusual decrease, as shown by the census of 1860 .

I. In 65 towns it was ascribed to emigration.

2. In 37 towns it was ascribed to consolidation of farms.

3. In 32 towns it was ascribed directly to the war.

4. In 25 towns it was ascribed to imperfection of returns in 1860 .

5. In 23 towns it was ascribed to discontinuance of manufactures.

6. In 18 towns it was ascribed to increased mortality.

7. In 18 towns it was ascribed to removals to Canada to avoid draft.

8. In 15 towns it was ascribed to decrease or discontinuance of the lumber business.

9. In 2 towns it was ascribed to deaths in military service.

Io. In I t towns it was ascribed to completion of railroads.

II. In II towns it was ascribed to removals to the Pennsylvania oil fields. 
the Union party were loud in their denunciation of what they termed Depew's "census fraud."

The statistics of the State census for 1865 reveal some interesting facts. The native-born citizens formed 67.84 per cent of the population. ${ }^{2}$ The negroes, who had been steadily diminishing for the previous twentyfive years, numbered 44,708, forming but o.0II6 per cent of the total population. The number of manufacturing establishments reported was 17,522 , with a capital of $\$ 175,95^{2,228}$, and a product of $\$ 349,185,357.3$ These figures, compared with those of the United States Census of 1860 for New York State, show a decrease of 5, IO2 in the number of manufacturing establishments, an increase of $\$ 3,056,576$ in the capital invested, and a decrease in the annual value of the products of $\$ 29,685,582 . .^{4}$ It should be suggested that the people of the State may have given inaccurate figures to the enumerators as to the number and age of male children owing to a fear of military conscription. The complete figures on manufacture were doubtless withheld, for fear of public contumely over an increase of wealth at the government's expense, or through fear of special taxes. Further, there was a suspicion abroad as to the honesty of the census report. The Democratic State Convention adopted a resolution which charged Secretary of State Chauncey M. Depew and his assistants with fraud. Whether the Unionists did actively conspire to rob the Democrats of

${ }^{1}$ Syracuse Daily Courier and Union. Sept. 25, 1865.

${ }^{2}$ Census for the State of Neze' York, 1865, p. 121.

'Ibid., p. 479.

'Eighth Census of the United States, I860, Manufactures, p. 419. In 1860 the number of establishments equaled 22,624 . In i 860 the capital invested equaled $\$ 172,895,652$. In 1860 the annual value of products equaled $\$ 378,870,939$. 
their laurels for having kept the State in a prosperous condition, we are unable to say. At any rate there was a persistent belief current that the prosperity of the State had been greater than the returns declared. It appears strange to me, that there should have been such a decrease in the annual value of the manufactured products, in view of the call for war supplies and the prosperous condition of agriculture. ${ }^{\mathrm{T}}$

${ }^{1}$ For a résumé of the religious and allied activities in New York State in 1865, see City Mission and Tract Society Reports, I866, pp. I-I44. For the educational situation in New York State in 1865 , see Fairlie, Centralization in New York, passim. Laws of New York, 1795, ch. lxxv, pp. 248-54; ibid., I844, ch. cccxi, pp. 464-5; ibid., I854, ch. vii, pp. 230-232; ibid., I856, ch. clxxix, pp. 285-96; ibid., 1864, ch. cccclv, pp. 1281-4. New York, Report of Superintendent of Public Instruction, 1866. Annual Report of the City Superintendent of Schools, New York City, i866. City Mission and Tract Society Reports, 1866, p. 132. Annual Report of the Finance Committee of the Board of Education, 1865, no. 13, p. 8. (Documents of the Board of Education.) 


\section{CHAPTER III}

\section{Party Politics in New York During 1865}

Although we have found New York State generally prosperous at the close of the War, matters politically were far from satisfactory. New York City at that time was in the grasp of the notorious Tweed Ring, while the State was being mulcted by a corrupt Canal Ring under the Unionist flag.' Further, the fight in New York between supporters of the Union and Copperheads had left many scars, especially as a result of the campaign of the previous year. Horatio Seymour, the Democratic War Governor, had made himself so obnoxious to the supporters of the administration that next to the election of Lincoln his defeat was the end most desired. Reuben E. Fenton, of Chautauqua, was the instrument which brought about Seymour's downfall. ${ }^{2}$ Seymour, who had

${ }^{1}$ As the exposures which shattered these corrupt rings came in the seventies the matter lies without the province of this monograph.

2 The Union State ticket was:

Governor-Reuben E. Fenton, of Chautauqua.

Lieutenant-Governor-Thomas G. Alvord, of Onondaga.

Canal Commissioner-Franklin A. Alberger, of Erie.

Inspector of Prisons-David P. Forrest, of Schenectady.

Electors-at-Large-Horace Greeley, of New York.

Preston King, of Ogdensburg.

New York Tribune, Sept. 8, 1864.

The Democratic ticket was:

Governor-Horatio Seymour, of Oneida.

Lieutenant-Governor-David R. Floyd-Jones, of Queens.

Canal Commissioner-Jarvis Lord, of Monroe.

Inspector of Prisons-David McNeil, of Clinton.

Electors-at-Large-William E. Kelly, of Dutchess.

Washington Hunt, of Niagara.

New York Tribune, Sept. I6, 1864 . 
declared that the war would be a failure, and whose speech at the National Democratic Convention at Chicago was a malignant arraignment of the administration, ${ }^{x}$ was discredited.

When it became known shortly after the polls closed on election day that Lincoln's victory in the country had been overwhelming, the outcome in New York was still doubtful. However, the final returns for the State gave Lincoln a majority of 6,749 over McClellan. ${ }^{2}$ On the vote for Governor, Fenton ran ahead of Lincoln's vote by 822 . Mr. Fenton received 369,557 and Mr. Seymour 36r,264, which made Fenton's majority $8,293 .{ }^{3}$ In the Legislature the Unionists had the controlling influence. ${ }^{4}$ Twenty Unionists and twelve Democrats constituted the New York delegation in the House of Representatives. Roscoe Conkling, of Utica, and John A. Griswold, of Troy, both men of prominence in New York politics through this period, were typical of the men sent to the Thirtyninth Congress.

This Congress, strongly Radical, was presently at cross purposes with President Johnson. The chief political interest of the early Reconstruction period centered around the battle which was waged between the President and Congress. The policy which Johnson pursued

'Public Records of Horatio Seymour, p. 231, Speech Aug. 30, I864. "This administration cannot now save this Union, if it would. It has by its proclamations, by vindictive legislation, by displays of hate and passion, placed obstacles in its own pathway which it cannot overcome, and it has hampered its own freedom of action by unconstitutional acts."

"Tribune Almanac, 1865, p. 48. In electoral votes for the whole country Lincoln had I79 and McClellan had 21. The popular vote in the State gave Lincoln 368,735; McClellan, 361,986. Lincoln's majority, 6,749.

${ }^{3}$ Ibid.

'Appleton's Ann. Cyclopedia, r865, p. 588. Unionists-Senate, 21; Assembly, 76. Democrats-Senate, II; Assembly, 52. 
was substantially Lincoln's. He limited the right of suffrage to white men, but favored qualified suffrage for the negroes. ${ }^{.}$The Radicals in Congress were not satisfied with Presidential Reconstruction, being averse to any policy which excluded the negroes from participation in public affairs. There were at least five prominent theories $^{2}$ in regard to the policy which should be pursued toward the South. Nevertheless, all the various party groups were of one mind in that some conditions should be imposed on the States which had rebelled. At first Andrew Johnson, who held that "Treason must be made odious," ${ }_{3}$ was of this opinion. ${ }^{4}$ All might have gone well had Johnson called an extra session of Congress or maintained his original policy. ${ }^{5}$ By continuing in relationship with his own party, the conservative elements in

${ }^{1}$ Fleming, Documentary History of Reconstruction (Cleveland, O., 1906), vol. i, p. 177. McPherson, History of Reconstruction (Washington, 1875$)$, p. 19.

${ }^{2}$ Dunning, Essays on the Cizil War and Reconstruction (New York, 1904), pp. 99-112:

I. The Southern Theory. War waged against an insurrection of individuals.

2. The Presidential Theory. Indestructibility of a State--suspended animation.

3. Charles Sumner's "State Suicide" Theory.

4. Thaddeus Stevens' "Conquered Province" Theory.

5. Forfeited Rights Theory. Compromise between the above sets.

${ }^{3}$ McPherson, op. cit., p. 46.

'Cf. Autobiography of Oliver Otis Howard (New York, 1907), vol. ii, p. 227.

${ }^{5}$ Instead the President restored all property rights, except as to slaves, to those lately in rebellion, provided they swore to support the constitution and obey the Emancipation Laws; pardoned those who had taken part in the war; and appointed Provisional Governors for the States lately in Rebellion except Arkansas, Louisiana and Tennessee. $C f$. McPherson, pp. 9-12. Blaine, Twenty Years in Congress (Norwich, Conn., 1884), passim. 
it would have modified his own action. ${ }^{x}$ Possibly, had Johnson yielded to Congress, when he saw it impracticable to proceed, as did President Grant, the South might have been saved the oppressive Reconstruction measures. ${ }^{2}$

But, as the Thirty-ninth Congress assembled, the late rebel States were largely coming into the hands of those who had engaged in the Rebellion. Their legislation apparently indicated a desire to keep out of power the loyal men. They were encouraged in this policy by the obstinacy of Johnson's course. Their attitude took on the nature of defiance and often resulted in insults to the loyal whites and oppressive acts toward the freedmen. ${ }^{3}$ These causes, together with Johnson's habit of denunciatory declamation, were a potent source for the animosity which arose between Congress and himself. ${ }^{4}$

A majority of the conventions held by both parties

'Colonel A. K. McClure's Recollections of a Half a Century (Salem, Mass., r902), pp. 6I-4.

${ }^{2}$ For a suggestive view of the Southern attitude in 1865 see The Nation, Nov. 23. 1865, p. 646; Apr. 12, 1866, p. 460. Garner, Reconstruction in Mississippi (New York, 1901), pp. 61-3. Carl Schurz's Report, Sen. Ex. Doc. no. 2, 39th Congress, 1st Sess., p. 3. The Nation, Nov. 23, I865, p. 646: "We have already commented upon the remarkable power of adaptation and the great practical sense displayed by the Southern people after the resistance in the field had ceased. . . They laid down their arms, denounced all attempts at guerrilla warfare, acknowledged that their slaves were free, and, in fact, gave the Government to understand that it had only to name the terms on which it would restore civil government in order to have them formally acceded to."

"Henry Wilson, History of Reconstruction (Hartford, I868), p. I5.

'McCulloch, in Men and Measures (New York, I888), pp. 373-4, says that these speeches were not induced by intemperance. "For nearly four years I had daily intercourse with him, frequently at night, and I never saw him when under the influence of liquor. I have no hesitation in saying that whatever may have been his faults. intemperance was not among them." 
during the summer of 1865 backed Johnson's policy. However, there were two notable exceptions: the Union Convention ${ }^{2}$ of Pennsylvania, and the Union Convention of Massachusetts. The former was under the control of Tharldeus Stevens; the latter under that of Charles Sumner. Yet Johnson did not feel disturbed. ${ }^{3}$ The North, nevertheless, took the action of Mississippi's convention, in its refusal to accede to the President's suggestion for a qualified suffrage, as indicative of Southern sentiment.

While the Provisional Governors were calling conventions in the remainder of the southern States, the various political forces were being gathered in the North. The Democrats of New York in State convention at Albany on September 6th and 7th, I865, developed a complete change of policy. The party avoided its former leaders and joined the ranks of Johnson supporters. Horatio Seymour, who was a delegate, failed to receive the presidency of the convention, a position logically his. Hon. J. M. Humphrey, of Erie, a man comparatively new in the Democratic State councils, received the honor. Samuel J. Tilden, who had been active under

'Rhodes, History of the United States (New York, I896), vol. v, p. 533. Tribune Almanac, I866, p. 43. Of the Union State Conventions held, Massacliusetts, Vermont, Maine, New York, Minnesota and Iowa, declared directly or indirectly for impartial suffrage without distinction of race. New Jersey, Pennsylvania, Ohio, Wisconsin, California and Colorado, did not mention the subject. Nevada declared against it.

${ }^{2}$ Appleton's Ann. Cyclopedia, i865, p. 693. The resolutions contained Stevens' conquered-province idea, and further " that Congress should declare as forfeited and vested in the government, the property of all rebels whose estates exceed the sum of $\$ 10,000$, and that the proceeds of the property so confiscated should be applied to increase the pensions of those entitled thereto by the casualties of the war, to pay the damages done by the enemy to loyal citizens, and to reduce the burden of the national debt."

${ }^{3}$ Rhodes, op. cit., p. 534. 
the old régime, was so discredited that, after a persistent canvass for the nomination for attorney-general, he was forced to refuse peremptorily the use of his name. On the other hand, John Van Buren, who was perhaps the leading War Democrat in the State and the inveterate foe of Seymour, was nominated for attorneygeneral. Another evidence of the change came in the nominations of Slocum and of Lucius Robinson. ${ }^{\mathrm{I}}$ The former had been a Republican member of the State Assembly in 1859 and at the time the war broke out was the Republican treasurer of Onondaga County. Slocum was named by the Democrats for secretary of state. Robinson's nomination for comptroller, the same office which he then held under the Unionists, was even stronger evidence of the change in Democratic sentiment. Robinson had been brought into public life by the Republicans in the campaign for Fremont and had acted with them until the present except that he had refused in 1864 to support Lincoln, whose conservatism disgusted him. The World, commenting on the change of Democratic ideas, declared that, "the Democratic party of New York will ride no dead horses; will fight no spent weapons; but will make a manly declaration of its views on the questions most important to be decided now and most fruitful of consequences in the future." The Times seemed unable to appreciate the Democratic change of heart. Its comment upon the World's statement was:

They parade this intention as if it were something very meritorious-a piece of self-abnegation that ought to be worth to the party a good many thousand votes. It is hardly worth

'Cf. also Rhodes, vol. iii, pp. 25-26.

"New York World, Sept. 6. I865. 
while to smile at this Falstaffian assumption of magnanimitythis cheap virtue of dropping all scandalous by-gones for the public good."

The convention, overlooking the war record of the party, praised the proud history of the Democrats. ${ }^{2}$ It congratulated the State and Nation on the return of peace. Subordination of the military to the civil rule, recognition of the equality of the States, and opposition to the use of any force to compel the States to adopt negro suffrage were proclaimed. This plank shows how far the Democrats of New York had drifted from their War Governor. Governor Seymour's demand ${ }^{3}$ that the New England States should not have twelve votes in the United States Senate while New York had but two was effectively silenced by the distinct declaration in the platform of the "equality of States." The convention recognized the obligation of the whole country to pay the national debt. It gave a vote of thanks to the soldiers and sailors, applauded the frank abandonment of slavery, and ended with a resolution to support Johnson in his policy, ${ }^{4}$ which, denounced by the Copperheads as tyrannical and cruel, was commended as evincing "enlightened statesmanship, sound political theory and an oldfashioned, time-honored regard for the relations and rights of the States and the Federal Government as established by the Constitution." A further resolution was adopted which charged the Secretary of State and his assistant enumerators with fraud in connection with

${ }^{1}$ New York Times, Sept. 7, 1865.

${ }^{4}$ New York World, Sept. 8, 1865.

New York Times, Sept. 8, 1865.

${ }^{4} \mathrm{New}$ York Evening Post, Sept. 6, 1865. The Evening Post had predicted the chief points which would appear in the Democratic platform. 


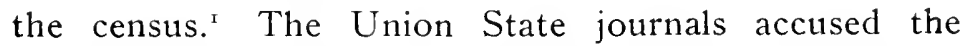
Democrats of "artfully dodging their record and profession," and of fearing to "make an issue with the Union party on any great public question." " These charges were rebutted by the Democratic journals on the points that Democrats had simply consented to drop the support of slavery, as the South had done, "but that they still stick to the basic principles of the ancient Democratic party . . . strict construction of the constitution ... States' rights and ... personal liberty." 3

The friends and neighbors of General Slocum in his home town, Syracuse, were loud in their pre-convention claims that Slocum would not accept the Democratic nomination. "The idea is too preposterous for belief. There is some infernal jugglery here, in which General Slocum is not a participant, but of which he is made the unconscious victim," ${ }^{4}$ was the opinion of

\footnotetext{
${ }^{1}$ New York World, Aug. I, 1865. New York Tribune, Sept. 8, I865. New York Evening Post, Sept. 6, 1865. Mr. Depew replied by letter to $\mathrm{Mr}$. Tweed's request for a reconsideration of the census returns for New York City, stating that he had no power to reopen the matter. Greeley defended Depew from the charge of fraud. "The letter of $\mathrm{Mr}$. Depew is plain and explicit. He is an officer of the law and must obey the law.... The Secretary of State appoints his agents, and takes their word sworn under oath. There his labor ends. . . Because the census of Mr. Secretary Depew did not carry out the estimates of that of Mr. Marshal Rynders, taken ten years ago, some of our Democratic newspapers began to howl and shout and cry 'fraud' . . Mr. Rynders being a disciple of the philosophy that labors to extract the largest number of votes from the smallest given number of voters, he made as much of Democratic New York as possible. ..."
}

${ }^{2}$ Albany Evening Journal, Sept. 8, 1865. Utica Morning Herald, Sept. 7, 1865. Ogdensburg Daily Journal, Sept. 8, 1865.

${ }^{3}$ Albany Argus, Sept. 9, 1865.

"Syracuse Daily Journal. Sept 7, 1865. Carroll E. Smith, editor of the Syracuse Daily Journal, was the ablest Radical editorial writer in central New York. 
Carroll E. Smith, one of his closest friends. The Syracuse Daily Standard, however, was not so loath to believe that Slocum would accept.' Faithful tc the last. the Syracuse Daily Journal, after Slocum had accepted the nomination, excused his conduct on the ground that the President had not sustained him in part of his military policy around Vicksburg. ${ }^{2}$ The Times ${ }^{3}$ said of General Slocum that it "knew of no reason why he should not have been the Republican candidate."

Lucius Robinson was well thought of by both parties. ${ }^{4}$ "He has proved a most faithful, valuable officer," said Greeley, "whom every would-be plunderer of the state regards with unfeigned detestation. Being a genuine Democrat, a true Republican, a hearty Unionist, and an inflexibly honest and faithful guardian of the treasury, he must be elected by a majority of more than half a million." ${ }_{5}$

'Syracuse Daily Standard, Sept. I I, 1865.

'Syracuse Daily Journal, Sept. 12. 1865. General Slocum had issued Military Order no. 22 to the effect that no district commander should permit any military organization within his district other than those under the control of the United States authorities. If any outrage occurred, an armed force should be dispatched to the scene and all persons disarmed within a radius of ten miles. President Johnson wrote a letter suggesting the establishment of a citizen militia in each county of Mississippi, which of course was against the Slocum order. The cause for Order no. 22 was that Governor Sharkey ordered the formation of two militia companies in every county of Mississippi. Slocum then issued his order, basing it on the lawlessness in the state against blacks, Union soldiers, messengers and sympathizers. Governor Sharkey had appealed to Johnson, who sustained him.

${ }^{3}$ New York Times, Sept. 8, 1865.

4 New York Evening Post, Sept. 18, 1865.

${ }^{5}$ New York Tribune. Sept. 9, 1865. 
"The ticket is not personally strong, but politically liberal;" said the World... "This is a generous recognition, by the convention, of the fact that the main questions on which parties have divided for the last ten years have ceased to have any vitality." In precise

${ }^{1}$ New York World, Sept. 8, 1865.

The Democratic Ticket was as follows:

Secretary of State-Henry W. Slocum, of Onondaga.

Comptroller-Lucius Robinson, of Chemung.

Attorney-General-John Van Buren, of New York.

Treasurer-General Marsena R. Patrick, of Ontario.

State Engineer--Sylvanus H. Sweet, of Oneida.

Canal Commissioner-Cornelius W. Armstrong, of Albany.

Prison Inspector-Andrew J. McNutt, of Allegany.

Judges of the Court of Appeals-John W. Brown, of Orange. Martin Grover, of Allegany.

Clerk of Appeals-Edward O. Perrin, of Kings. New York Tribune, Sept. 8, 1865.

The Union Ticket was as follows:

Secretary of State-General Francis C. Barlow, of New York.

Comptroller-Colonel Thos. H. Hillhouse, of Ontario.

Attorney-General-General John H. Martindale, of Monroe.

Treasurer-Colonel Joseph Howland, of Dutchess.

State Engineer-J. Platt Goodsell, of Oneida.

Canal Commissioner-Robert C. Dorn, of Schenectady.

Prison Inspector-General Henry IV. Barnum, of Onondaga.

Judges of the Court of Appeals-Ward Hunt, of Oneida.

John K. Porter, of Albany.

Clerk of Appeals-Henry Jones, of Cattaraugus.

New York Evening Post, Sept. 21, 1865.

The Democratic State Central Committee appointed by the Convention was:

Ist District-Charles E. Carvell, Peter B. Sweeney.

2d District-Homer A. Nelson, William M. Parks.

3d District-Peter Cagger, T. L. Laffin.

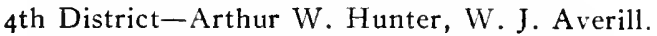

5th District-John A. Green, J. T. Spriggs.

6th District-Henry D. Barto, Christopher A. Waldo.

7th District-E. P. Ross, Charles C. B. Walker.

8th District-Dean Richmond, A. P. Lanning.

Buffalo Daily Courier, Sept. 8, 1865. 
contradiction Henry R. James, of the Ogdensburg Daily Journal, stated that "The resolutions put forth by the Albany Convention do not embody the real sentiments of the Democratic party and were only adopted for the purpose of securing the consent of a candidate whose acceptance was deemed essential to give the ticket even the air of respectability." " The Herald, however, commended the Democracy upon the fact that they had "recovered their temper, and see something that they can praise and rejoice over," . . . also, that

those intriguing politicians who were responsible for the follies and disasters of the party during the war were kept in the background of the Convention. In short the Convention appears content to let bygones be bygones, and have nominated a ticket representing almost every element of the floating material in opposition to the Chase radicals and secesh sympathizing elements, and drawn them together on the common platform of endorsement and support of the reorganization policy of President Johnson.

The "Democratic - Republican - Copperhead - Union League Convention," ${ }^{3}$ according to the Buffalo Express, ${ }^{4}$ had "resolved itself out of existence as a distinctive political organization;" but no trace of such an act could be found in the comments of its neighbor, the Buffalo Daily Courier. "The bold and unreserved enumeration of principles, the proud reference to the past history of the party in our country's glory and the manly grapplings with the new issues upon us, contrast most favorably with the timid policy and dodging of

${ }^{1}$ Ogdensburg Daily Journai, Sept. 19, 1865.

${ }^{2}$ New York Herald, Sept. 8, 1865.

${ }^{3}$ Rochester Daily Democrat, Sept. 8, 1865.

'Buffalo Express, Sept. 8, 1865. 
momentous issues by the Radical conventions throughout the States." r

With the exception of the New York News ${ }^{2}$ all of the New York City and State papers which claimed to be of the Democratic faith, endorsed the platform and candidates. Yet, certain of the more conservative up-State Democratic organs attempted to appeal to the War Democrats and those who had deserted to the Unionist side, on the basis that the candidates of the Albany convention were "honest men who have not in the past acted with the Democratic organization and who are not so wedded to the interests of any mere party as to render subservient to them the higher interests of the country." ${ }^{3}$ The Democratic candidates, even so, raised the question among the State Radical journals "whether a party which unconditionally surrenders can win a victory." " "The game of disloyalty has been played and effectually lost; and it is the evident purpose of the leaders to regenerate the party," was the complacent comment of the Evening Post upon the convention's nominees. $^{5}$

The Union Party, ${ }^{6}$ of New York, met in convention

${ }^{1}$ Buffalo Daily Courier, Sept. 8, 1865 .

${ }^{2}$ New York News, Sept. 5-12. See Rochester Daily Union and Advertiser, Sept. 9, 1865.

${ }^{3}$ Rochester Daily Union and Advertiser, Sept. 8, 1865.

"Albany Evening Journal, Sept. 7, 1865. Buffalo Express, Sept. 8, 1865. Binghamton Daily Republican, Sept. 8, I865.

${ }^{5}$ New York Evening Post, Sept. 6, 1865.

${ }^{6}$ The Republicans, under the leadership of Abraham Lincoln, avoided the use of the name Republican. They assumed the use of the term "The Union Party," in order to attract the War Democrats, without wliose aid it would have been difficult to end the Rebellion. The local Republican organizations were used, for the War Democrats had in general no definite organization. When the Conservative element suc- 
at Syracuse September 20, 1865 . In the words of Charles J. Folger, temporary chairman of the convention: "The contest adjourned from the forum to the battlefield and fought out successfully, as we supposed, in the field has been adjourned once more to the forum. We have already beaten the foe, we must press on and secure the fruits of victory which belong to us." I Secretary of State Chauncey M. Depew, on taking his seat as permanent president of the convention. exhibited his characteristic good humor. In denouncing the Democrats for trying to reap the results of the war when they had so opposed it, he was reminded of the adage:

"When the Devil was sick, the Devil a monk would be; When the Devil got well, the devil a monk was he."

Certain of the Radical journals gave an unpleasant display of political snobbishness in stating that there was not much diversity of opinion among the delegates and that just a fair ticket would be elected. ${ }^{3}$ But this must not be taken for the attitude of, perhaps, the majority of

ceeded in counteracting the influence of the Radical wing of the Union Party in 1868 , the tendency toward a rejuvenation of the Republican Party manifested itself. The term "Radical" did not please the Conservatives, while there was little necessity for a further use of the term "Union." Hence, the adoption of the official title, "The National Union Republican Party," by the national nominating convention of I868. The term "Union" was dropped from the official title by the National Convention of 1872 .

Professor W. A. Dunning gives an excellent discussion of "The Union Party," in an article entitled "The Second Birth of the Republican Party." The American Historical Review, XVI, no. I, Oct., I9ı, pp. 56-63.

${ }^{1}$ Utica Morning Herald, Sept. 22, 1865.

'Syracuse Daily Journal, Sept. 21, 1865.

${ }^{3}$ Rochester Daily Democrat, Sept. 20, 1865. 
the Unionist delegates, who under the leadership of Ellis H. Roberts realized that "Haste makes waste." "

It was popular in both parties ${ }^{2}$ to nominate prominent soldiers. Major-General Barlow, ${ }^{3}$ who behaved so splendidly at Antietam, was nominated for Secretary of State in place of Chauncey M. Depew.4 Depew, whose chances were very favorable for a renomination, made himself a victim on the altar of party good and declined to have his name considered. The other civilians who had been elected upon the 1863 ticket also gave way to the soldier candidates. General John H. Martindale, a West-Pointer, was chosen for attorney-general over Cochrane. For inspector of prisons, General Henry W. Barnum was selected in place of Bates.

Practically the same conditions existed in the Union Convention as had prevailed in that of the Democrats at Albany. War Democrats elbowed Conservative and

${ }^{1}$ Utica Morning Herald, Sept. 29, 1865.

"Harper's Weekly, under the title "New Parties: We are at the end of parties" said: "Of the parties that existed when the war began the name 'Democratic' a'one remains. The Constitutional Union Party survives only in John Bell drinking success to the rebellion in bad whiskey. The Republican Party as such has secured its great object of limiting the extension of slavery. The necessities of the case, in a nation waging a civil war, divide us all into two bodies: those who support the administration in its war policy and those who do not. But the old party lines do not separate us. The Party of the Administration is composed of men as different as the late Edward Everett, General Butler, John A. Griswold, Thurlow Weed and Charles Sumner, who were respectively leaders of the Bell-Everett, the Breckinridge, the Douglas parties and both wings of the Republican Party before the war. We are at the end of parties." Harper's Weekly, IX, 114, Feb. 25, 1865 .

${ }^{3}$ Cox, Military Reminiscences of the Civil War (New York, r9oo), vol. i, p. 330 .

"The vote for Secretary of State was: General Barlow, I9r; General Van Wyck, 172; General Daniel E. Sickles, 3; C.' M. Depew, I. 
Radical Unionists. Thurlow Weed urged the Unionists to go into the campaign with no candiclates whose affiliations had been Democratic. ${ }^{x}$ Yet, due to the laissez faire attitude of the delegates, or perhaps better the lack of an esprit de corps. General Barlow, ex-Democrat, received the chief nomination, which was termed by the Argus as an insult to Democratic voters. ${ }^{2}$ General Sickles, who ran for the same nomination, had also been a Democrat. It was he who had stated in the House of Representatives that New York City would free itself from the dominion of the State government in the event of secession. ${ }^{3}$ Daniel J. Halstead, the leading Democratic editor in the central portion of the State, explained to the Radicals of the State that General Barlow had been preferred because he was unknown and had not made himself obnoxious to the leaders, while Depew had been "shuffled off with a resolution endorsing his census frauds, and Van Wyck without even a resolution of thanks for herding with the negroes." ${ }_{4}$

The resolutions adopted by the Unionists were the result of contending forces in the Convention. The Radicals of the party claimed the majority by 70 to $50 .{ }^{5}$ Nearly all of the Radicals came from the interior and northern portions of the State, while a majority of the

${ }^{1}$ Albany Evening Journal, Sept. I6, I865.

${ }^{2}$ Albany Argus, Sept. 23, I865.

${ }^{3}$ Burgess, Civil War and the Constitution (New York, 1906), vol. i, p. 147; Brummer, Neze York During the Civil War (New York, I911), p. 125 .

“Syracuse Daily Courier and Union, Sept. 25, 1865. Ending his review of the Union Convention, Mr. Halstead wrote: "Let the combative Raymond, the depopulating Depew, and the prodigious Barnum, be held in everlasting remembrance as the triple prodigies of the occasion."

${ }^{5}$ New York Times, Sept. 20, 1865. 
delegates from the southeastern counties were conservative. The Conservatives were equally assertive of their control. Through the adroitness of Thurlow Weed in preventing a test vote, it is difficult to state with exactness which side had a majority. It appears, nevertheless, that the prevailing opinion among those in attendance was Radical. Among the more prominent of the Radicals were Charles S. Spencer, of New York. Charles J. Folger, chosen as temporary chairman, General C. H. Van Wyck, of Orange County, and Horace Greeley. The latter appeared indifferent to the nominations but insisted that the platform should be positive and should read a lecture to the administration at Washington. ${ }^{\mathrm{r}}$

However, Henry J. Raymond and Thurlow Weed controlled the convention. They had openly declared themselves for Johnson. ${ }^{2}$ Preston King, of Ogdensburg, a former colleague and friend ${ }^{3}$ of Johnson's in Congress, and William H. Seward represented the two factions in

'New York Tribune, Sept. 21, I865.

${ }^{2}$ New York Times, Sept. 20, I865. See Albany Evening Journal, Sept. 2I, I865. The World looked upon "the conduct of the WeedRaymond club, in respect to support of President Johnson," as " that of jealous petulant children. They insist that the executive shall have no friends unless they be enrolled in the little joint-stock company of which Seward is president, Weed is treasurer, and Raymond is managing agent. They would exclude, first, the Democrats, who comprise more than half the voters of the State; and next, the Greeley Republicans, who make up very much more than one-half of the remaining voters. Mr. Johnson has no idea of making the number of his friends in this State so 'conveniently small' as Mr. Seward would advise." New York World, Oct. 18, I865.

${ }^{3}$ King's friendship for Johnson is shown by a letter which Sumner wrote to Francis Lieber, "Aug. IIth... Preston King and Mr. Blair went to the President when he was intoxicated and took him away from the hotel and sheltered him at the house of Mr. Blair." Pierce, Sumner, vol. iv, p. 250. 
New York which had been contending for Johnson's favor. Differences were patched up, however, and King accepted the office of Collector of the Port of New York which he held but a short time, owing to his untimely death. ${ }^{1}$ It was generally believed that Weed controlled King who was the dispenser of custom-house patronage. provost-marshals, internal revenue officers and indirectly of postmasters. That Weed used this indirect control over the national patronage within the State to regulate matters in the Union State Convention was advanced as the reason for his power over the Radicals.

The facts as to the refusal of Chauncey M. Depew to stand for the renomination for secretary of state illustrate Weed's peculiar power. The usual rumors and counter-rumors attendant upon the eve of a political convention assumed all manner of phases during the night of September 19th. Weed had ascertained shortly after midnight that the Radicals had decided upon Senator Folger as temporary chairman. Adopting Folger's name at once, Weed gave out that Folger belonged to the Conservative side of the house, thus attempting to receive credit for bringing his name before the Convention. Weed still continued to press the name of General Barlow for the highest office to be filled. To counteract this movement the Radicals worked for Depew with such success that it looked for a time as if he would beat out the soldier-candidate. Thereupon, Weed sent for Depew, to whom he stated that if he (Depew) wanted the nomination assurance could be given that no name would be presented against him by the Conservative side. Depew, having thus been tendered the nomination

${ }^{1}$ He jumped from a ferry boat in a moment of insanity while crossing the North River. 
by both factions with the promise that no opposition would be encountered, declined to be considered as a candidate. The convention was officially informed at ten o'clock on the 2oth that Depew declined to permit the use of his name. As a mark of esteem, both sides agreed to give Depew the permanent presidency of the convention. ${ }^{\mathrm{x}}$

The failure of the Radicals to gain the upper hand in the convention gave the Democrats much amusement. The Buffalo Daily Couvier argued for the Radicals that in view of their numbers they had been entitled to greater power in the convention and should look to Weed for satisfaction. ${ }^{2}$ The Argus told Greeley that all he lacked in order to make a leader was courage ; ${ }^{3}$ while the Utica Daily Observer consoled the Unionist convention by stating that it was not the only place where Radicalism had come to grief. ${ }^{4}$

Taking courage from the action of Ohio, Pennsylvania and Massachusetts, ${ }^{5}$ the Radicals in the Convention decided to vote for a resolution which affirmed the right of all loyal southerners, that is, negroes, to have a vote in the reorganization and management of their several State governments. ${ }^{6}$ The Radicals had caught the spirit of Sumner, Stevens and Wade, who already had discerned that Johnson was not to be moved. ${ }^{7}$ The Presi-

${ }^{1}$ New York Herald, Sept. 21, 1865.

${ }^{2}$ Buffalo Daily Courier, Sept. 22, 1865.

${ }^{3}$ Albany Argus, Sept. 22, 1865.

+Utica Daily Observer, Sept. 22, 1865.

${ }^{5}$ New York Trubune, Sept. 20, 1865; Sept. 22, 1865.

' New York World, Sept. 21, 1865; New York Evening Post, Sept. 2I, 1865 .

${ }^{7}$ Senator Wade, of Ohio, and Stevens made several attempts to convert the President to their policy. 
dent during the first month of his administration had given the Radical leaders cause to believe that he favored the immediate enfranchisement of the negroes. Sumner, on April 25th writes: "On Saturday the Chief Justice and myself visited him in the evening, especially with the view of conversing on negro suffrage. Suffice to say that he is well disposed, and sees the rights and necessities of the case. ... I am confident that our ideas will prevail." ${ }^{-}$But Johnson, within a month, on reaching a final decision, completely reversed his policy. Due to popular indifference and discord among the Republicans, Thaddeus Stevens, Henry W. Davis and Senator Wade saw little chance of success against the Executive influence and patronage. ${ }^{2}$

In the Union State convention. Horace Greeley and Henry J. Raymond came into abrupt collision. ${ }^{3}$ Greeley believed that the negro-suffrage resolutions, which practically would have forced New York into the line of opposition toward Johnson's program, would have passed had it not been for Raymond. The latter was afraid that such an action would place the State in the hands of the

' Edward L. Pierce. Memoir and Letters of Charles Sumner (Boston, 1893), vol. iv, p. 24I. Letter to F. W. Bird.

'Ibid., 25I. The public men outside of Congress, journalists and other molders of public sentiment, gave Sumner's cause little support at first. Governor Andrew, (a) of Massachusetts, and Governor Morton, (b) of Indiana, denounced it. Bryant and Godwin, (c) of the Ezening Post, contended against compulsory action in the matter of suffrage. Raymond, (d) of the Times, took strong ground against negro suffrage as a part of reconstruction. Charles A. Dana, then of the Chicago Republican, urged Sumner not to break with the President. (a) Letter to Sumner, Nov. 21, 1865. (b) Julian, Political Recollections (Chicago, 1884), pp. 260-68. (c) Godwin, Life of Bryant (New York, 1883), vol. ii, pp. 238-42. (d) New York Times, Sept. 21, 1865 .

'New York Times, Sept. 20, 1865; ibid., Sept. 21, 1865. 
Democrats through their support of the administration measures. ${ }^{x}$ Greeley did not make a decided leader for the Radicals, ${ }^{2}$ so in the absence of another, Raymond was able to enforce his views in the platform.

The Convention congratulated the people of the State on the overthrow of rebellion and the return to peace. It thanked the soldiers and sailors of all ranks. It deplored the death of Lincoln and recognized "in Andrew Johnson his successor, a statesman of ability, experience and high toned patriotism and the most unsullied integrity" ... and further "that we renew to him in his administration those assurances of cordial and effective support which were tendered by us in his nomination and election." Approval was given of the initial steps which the President had taken toward a relaxation of military authority in the southern States. Moreover, approval was given of the restoration to the public of complete control of civil affairs, "just as soon as it may be found compatible with the preservation of order, . . . the exclusion of slavery, and the fulfilment of the constitutional obligations of the national authority to guarantee to every state a republican form of government." ${ }_{4}$

The platform affirmed that the national sovereignty over the subjects committed to it under the Constitution had been maintained by the War. And that whenever

${ }^{1}$ The convention had in attendance a majority of at least, fifty professed Radicals. However, they had no cohesion or discipline. Hence, they were seldom able to profit from their strength. No doubt, had a resolve been in order which distinctly affirmed the right of all loyal people in the South to a voice in the reorganization and control of their several State governments, it would have passed with ease.

${ }^{2}$ The New York World spoke of the Syracuse platiorm as a "shabby attempt to indorse Secretary Seward's conduct." New York World, Oct. 4, I865.

${ }^{3}$ New York Tribune, Sept. $21,1865$.

$\checkmark$ Ibid. 
the considerations of public safety macte it wise, the States lately in rebellion should be restored to the exercise of their several rights under the Constitution. It held the national debt inviolable and approved of the administration's foreign policy. Among the minor resolutions, it denounced as "false and calumnious" " the slurs cast by the Democratic Convention upon the honesty of Chauncey M. Depew, and indorsed his official conduct as Secretary of State.

The editorials of the Unionist papers were so uniform in their complacent approval of the Union platform and candidates, that no special mention need be made. ${ }^{2}$ Thurlow Weed called the resolutions "clear, concise, and emphatic." 3 But his neighbor, Mr. Cassidy, saw in them the narrow exclusiveness and rivalries of "clique predoninance," + which he contrasted with the widened

'New York Tribune, Sept. 21, 1865.

${ }^{2}$ The Radical papers which especially praised the Union platiorm were: the Buffalo Commercial Advertiser, Auburn Advertiser, Syracuse Daily Journal, Utica Morning Herald, Albany Evening Journal, Troy Times, and Rochester Democrat. A campaign joke was published by the Argus which reacted under the ready wit of Carroll E. Smith, of the Syracuse Journal, upon Dean Richmond, much to his discomfort. On September 21, 1865, the Argus printed a telegram which read:

$$
\text { "Syracuse, Sept. 20, I P. M. }
$$

"All gone to h-... Will leave for home on the two o clock train."

The Argus used it to show that the Unionist hopes had gone sky high, but the Journal turned it to mean that all hopes for the Democratic ticket had vanished. This interpretation the Jonrnal claimed was in keeping with the language and conviction of Dean Richmond, when he replied to the threat of the Buffalo railroad strikers that they would bolt the Democratic ticket this (1865) fall. His reply on that occasion was illuminating, if not in strict accord with good taste. It was: "The Democratic party has gone to $h-$, and you may go too." Syracuse Daily Journal, Sept. 22, I865; Albany Argus, Sept. 21, 1865.

"Albany Ez'ening Journal, Sept. 12, 1865.

'Albany Argus, Sept. 25, 1865. 
purpose of the Democrats in bringing in all honest men. The Buffalo Express appeared to have reverted to its infancy; for it professed to believe in the sincerity of the Radical endorsement of President Johnson. ${ }^{\text {. }}$

The campaign which followed was brief and without moment. The Evening Post on October I Ith, gave three reasons for the inactivity and political negligence which manifested itself in the campaign.

In the first place, the excitements of the great war have been followed by their natural reaction; lassitude has succeeded to transport and indifference to intensity.... Another reason for this indifference is that both parties... in the State of New York especially ... have put in nomination some of their best men, from whom we have a right to anticipate a safe and sound administration, in the event of the success of either.". . . But there is a third cause of political inactivity, not so obvious, and yet more potent than the others; and that is a growing conviction that the old parties must soon give way to new combinations. . . One of them, indeed, the so-called Democratic party, is already half-dead;... its candidates and its principles are alike assumed for an occasion; but its vitality is paralyzed and its memory grows rotten. ${ }^{2}$

The prediction of the Evening Post, however, has proved unsound, ${ }^{3}$ for both of the major parties have passed

1 Buffalo Express, Sept. 22, 23, 25, 1865.

'New York Evening Post, Oct. II, 1865.

${ }^{3}$ Syracuse Courier and Union, Sept. 8, 1865. The Courier foresaw the new line of cleavage foretelling the Reconstruction period. "The candidates put in nomination prove the growing sentiment even among Republicans, that the issues on which that party was originally based, have passed away and that on the new issues now raised by the extremists they feel themselves at liberty to array themselves in accordance with the dictates of their own judgment and in antagonism to the utterances with which the extremists are seeking to lead Republicanism into hostility to the President's reconstruction policy, as declared." 
through the dark valleys and troublesome waters of political strife.

As was natural, the Democrats tried to throw the Unionists into a bad light with the President. The Radicals were accused of strong opposition to the President's policy on the question of negro suffrage. This imputation was urgently denied by the moderate and conservative Unionists, who demanded that they be given full faith and credit for the sentiments incorporated in their platform.

The Evening Post exhorted the southerners to "go about their peaceful industries, obey the laws, ... secure equal justice to all," " thus to gain an early withdrawal of troops and a return to peace. It cautioned the North and South against the misrepresentation of facts by the Democrats. The power of the Radicals was discounted in the effort to support the platform written by Raymond. ${ }^{2}$ The Herald came forth in a strong effort to second Raymond's position in the platform. Speaking of Mr. Stevens and Mr. Sumner the Herald said:

They are mere politicians, looking to party objects . . having no other political hobby to ride, they will hang on the negro. How different with President Johnson. He is as much opposed to consolidation as he is to secession. He is neither a visionary nor a cynical factionist.... He sees, as every statesman would see, that the only duty he has to perform is to enable the States to resume their legitimate functions as members of the Union. ${ }^{3}$

Even Seymour was forced to concede that national affairs had taken an unexpected turn for the better. Still, his attitude was narrow and unpatriotic. He confined his

'New York Evening Post, Sept. 30, 1865.

${ }^{2}$ Ibid.

${ }^{3}$ New York Herald, Sept. 28, r865. 
vision to one of war debts and increased burdens as a result of the war. ${ }^{\text {. }}$

Several minor personal issues added life to the campaign. Much bitterness resulted from an unjust comparison by Horace Greeley, of General Slocum with Benedict Arnold." The Tribune also repeatedly hurled the charge of "cotton thief" at General Slocum. ${ }^{3}$ These slanders were keenly resented by the World. ${ }^{4}$ which charged that it was Thurlow Weed alone who prevented the nomination by the Unionists of both General Slocum and Lucius Robinson. ${ }^{5}$ John Van Buren, who was running for attorney-general with the Democrats, came out bitterly against Seymour, blaming him and Vallandigham for the party's blunder on the war issues. ${ }^{6}$ Greeley humorously remarked:

It isn't fair for John to deal so largely in sophistry and rigmarole in his public addresses, and keep his truth and sense for small knots of personal admirers. But, if he will do this, let him take care that Secretary Depew is among his hearers

${ }^{1}$ New York World, Nov. 4, 1865. In an exhaustive speech at Seneca Falls, New York, Seymour made a complete survey of the political situation. He rebuked party passions; put the question, "Why is the Union not restored?; " assured Johnson that the Democrats would aid him in carrying out his pledge to restore the Union; attempted to show how the workingman would be hurt by a Republican victory; and maintained that " when you decide this government has the right to say who shall and who shall not vote in the Southern. States, you decide that it has power to say who shall and who shall not vote in a Northern State."

"New York Tribune, Oct. 31, 1865.

${ }^{3}$ Ibid., Oct. 26, I865.

${ }^{4}$ New York World, Oct. 20, I865; Oct. 28, i865; Nov. 2, I865.

${ }^{5}$ Ibid., Oct. 26, I865.

${ }^{6}$ New York Tribune, Nov. 3, I865; Albany Evening Journal, Oct. 23,1865 . 
and then put into his next speech what Depew says of him. That will do it. ${ }^{1}$

Mr. Chauncey Depew had stated a short time previous that in a familiar conversation with him, Mr. John Van Buren had pronounced Horatio Seymour " a political accident" and "a damned fool." At that time Van Buren had demurred to the retailing of private conversations and had specifically acknowledged "the great intelligence and singular personal and official purity" of Mr. Seymour. ${ }^{2}$

Among the Republicans a violent personal controversy arose between Thurlow Weed and Horace Greeley. Each used his own newspaper to vituperate the other. ${ }^{3}$ The Nation suggested that both gentlemen leave their private quarrels out of the newspapers and settle it in a correspondence. ${ }^{4}$ The Nation gave an apt characterization of these two men which it might be illuminating to quote in part :

We believe no man who knows him can sincerely doubt the perfect personal integrity, the scrupulous veracity and the catholic benevolence of the editor of the Tribune. Mr. Weed, during his long career as a political leader, has made many enemies. Whether deservedly or not, he has the reputation of being a man of intrigue; and if parties are to be managed, as we suppose they must be while parties exist, nobody can bring to the work greater dexterity than $\mathrm{Mr}$.

${ }^{1}$ New York Tribune, Nov. 3, 1865. The attack against Seymour was first made at a small meeting in Troy, New York, after Van Buren had addressed a larger audience.

2 New York Herald, Nov. 2, I865.

${ }^{3}$ Albany Evening Journal and New York Tribune.

'The Nation, vol. i-ii, p. 265. The Times, also, urged harmony between the two lest the election should go to the Democrats. New York Times, Aug. 25, 1865. 
Weed has frequently displayed. Mr. Greeley, on the other hand, is not a good party tactician. Perhaps he is too honest : certainly he has too little control over a temper naturally violent. When he is angry, and he is often angry, he can no more keep a secret than he can live without breathing. When engaged in a dispute he rarely stops to cull nice phrases, and he has an uncomfortable habit of giving the lie direct. ${ }^{1}$

To turn the tide in favor of the Democrats and to overcome the ill-favor of the party caused by Seymour, Van Buren put forth herculean efforts in the campaign. He was backed by those in the Democratic Party who were rallying around John A. Dix as a future leader. ${ }^{2}$ The fact that General Henry W. Slocum, candidate for secretary of state on the Democratic ticket, and General Henry A. Barnum, candidate for inspector of prisons on the Union ticket, were residents of Syracuse made that city the center of the up-State campaign. It was here that John Van Buren, with the aid of Montgomery Blair and General John Cochrane, centered his forces. ${ }^{3}$

Following the example set by the New York City leaders, the campaign up-State degenerated into a series of personal charges against certain of the candidates on both tickets. General Barlow's conduct during the war was minutely inspected by the Democratic journals. The defeat of the Union forces at Cold Harbor was attributed to him. His unpopularity with the privates

\footnotetext{
'The Nation, loc. cit. Speaking of Mr. Greeley, The Nation continues: "In one of his recent replies to Mr. Weed, he speaks of "that shameful, pernicious, systematic traffic in legislation, franchises, grants and immunities, whereby Thurlow Weed has become rich and infamous.' Mr. Weed retorts that Mr. Greeley is 'ambitious, selfish and false,' and intimates that he is a howling demagogue."

${ }^{2}$ At this time, however, a majority of the Democrats were in favor of Seymour.
}

"Syracuse Daily' Courier and Union, Oct. 23, I865, et al. 
was emphasized and stories were told of how he permitted his men who fell out of line from exhaustion on the march from the Wilderness to be cruelly and wantonly shot. ${ }^{\text {I }}$ The micl-campaign was also enlivened up-State by the raising of charges against General Barnum, which were designed particularly to injure his candidacy for the office of inspector of prisons. It appears that General Barnum had left Syracuse in the early part of the war as Colonel of the I49th Regiment of Volunteers, raised in Onondaga County. Shortly afterwards unpleasant rumors began to attach themselves to his name. These culminated on September 26, 1864, in fifty fellow citizens of his political faith submitting charges against him to Secretary of War Stanton. These were resurrected and fanatically waved by the Democrats to defeat his election. He was accused of violating the "rules of the service... to the prejudice and injury of the people of this county." " Further he was charged with selling commissions in the army and of absenting himself from his command without excuse. ${ }^{3}$ These charges seem to have been pigeon-holed by Stanton but testify to Barnum's unpopularity among his fellow townsmen and his regiment. ${ }^{4}$

In defence of General Barlow the Unionist papers priated the report of his brigade commander praising him for his bravery at Antietan. 5 But regarding General Barnum no particular refutation appears to have been attempted other than the usual party praise. ${ }^{6}$ By way of

'Syracuse Daily' Courier and Union, Sept. 25, I865. ' 'Onondaga.

${ }^{3}$ Syracuse Daily Courier and Union, Oct. 23, 1865.

${ }^{4}$ Conversation with Duane S. Hurd, Sergeant I49th N. Y. V.

${ }^{3}$ Syracuse Daily Journal, Oct. 6, 1865.

${ }^{6}$ The Elmira Daily Advertiser lauded Barnum unstintingly throughout the campaign. 
reprisal the Union journals made capital out of General Slocum's sudden change of faith. Even his sometime staunch supporter, Carroll E. Smith, printed an indirect attack on Slocum. A list was given under thirteen heac's of those who would support Slocum, among them being :

The men who fled to Canada to avoid the draft and who deserted from the army after being enlisted. The men who swore that the war was a failure. The men who swore that it was a ' $\mathrm{d}-\mathrm{d}$ nigger, abolition' war. The men who hoped that every man who went to war would he killed. The men who were all the time for peace on any terms.'

The Syracuse Daily Standard, a Radical journal, was not so easy with Slocum but lampooned him freely. ${ }^{2}$ However, it could not go so far as to believe the charges of an unsigned Vicksburg contribution to the Chicago Republican, which accused General Slocum of being the leader in a gigantic fraud to swindle the government. ${ }^{3}$ The weight of public sentiment in both parties favored Slocum, his questionable turn-over in politics notwithstanding. Horace Greeley could say no worse of Slocum than "Slocum is very dispassionate, indeed, it is the worst fault we have to find with him." ${ }_{4}$ Even Harper's Weekly found him a man "whose uprightness and honesty are beyond question, and whose patriotism has come out of the furnace-heat of a four years' war as bright and unsullied as the stars of the flag he fought for." ${ }_{5}$

' Syracuse Daily Journal, Oct. I9, 1865.

2Syracuse Daily, Standard, Oct. 5, 1865.

"Ibid., Oct. 6, I865. The Tribune published similar charges.

"Quoted in Syracuse Daily Courier and Union, Oct. 16, 1865.

${ }^{5}$ Harper's Weekly, Oct., I865. The Boston Transcript gave a calm 
Many of the Radical State journals made campaign capital out of the published statement of ex-Congressman John B. Haskins, who had framed the resolutions of the Democratic convention but had since fallen out with certain of his colleagues. He stated that Manton Marble of the New York World, and Mr. Cassidy of the Argus, had submitted resolutions to the Democratic convention which were partly thrown out. In explaining his motives Mr. Haskins stated:

I knew that some of our leaders, so called, desired a simple indorsement of him [Johnson] to divide and conquer the enemy; but with me the paramount idea ... and it induced me to go to the Convention, in view of the curse of the Chicago Platform ... was to avoid the Bourbon Vallandighamism of the Ohio, the Jerry Black Buchananism of the Pennsylvania, the Camden and Amboy Rip Van Winkleism of the New Jersey, Democratic Platforms, and to give President Johnson a sincere and hearty indorsement. ${ }^{1}$

Uniformly the Democratic orators and journals sought to divert the discussion from Seymour's Chicago Platform, the issues of which were now "stone dead." " Seymour ended the campaign for the Democrats upState, at Seneca Falls, on November 5 th. The burden of his address was a rebuke to party passions, a plea for restoration of order and for sound finance. ${ }^{3}$

This address was made to offset that of Secretary

dispassionate approval of Slocum and his mid-campaign speech. Quoted in Syracuse Daily Standard, Oct. I3, 1865. The Buffalo Daily Courier proved an earnest champion of Slocum against Radical attacks, Sept. 28, Oct. 15, I865.

1 Syracuse Daily Journal, Sept. 23, 1865; Rochester Daily Democrat, Sept. 25, I865; Utica Morning Herald, Oct. 24, I865.

${ }^{2}$ Syracuse Daily Conrier. Oct. I, 1865; Albany Argus. Sept. 17, I865.

"Rochester Daily Union and Advertiser, Nov. 6. 1865. 
Seward to his neighbors in Auburn, on October 2oth. No double construction could have been placed upon Seward's remarks in support of the administration:

This I maintain and confidently proclaim, that every important decision of the administration has been wise. I maintain with equal firmness and declare with still greater pleasure the . opinion that no council of government ever existed in a revolutionary period in any nation, which was either more harmonious or more loyal to each other, to their chief, and to their country.'

In the light of later events we can see where Seward was misled.

Montgomery Blair, who had been drafted into the New York campaign by John Van Buren, followed in the footsteps of Seward and devoted practically all of his campaign speeches to proving to the Democrats that their best policy was to support the President. ${ }^{2}$ But the good effect of Blair's labors was largely spoiled by the oratorical genius of Wendell Phillips, who enlivened the campaign by his attacks on President Johnson. ${ }^{3}$

Although the legislature of New York was not airing any of its dirty linen at the time of the campaign, still its past reputation and the generally known control which

${ }^{1}$ Syracuse Daily Standard, Oct. 23, 1865; Buffalo Daily Courier, Oct. 27, 1865. The Daily Courier considered Seward's speech a "studied, desperate attempt to undermine public confidence in the President and to divert public attention from the great issues of the campaign.',

${ }^{2}$ Buffalo, Daily Courier, Oct. 21, 1865. Perhaps there was no more faithful advocate of Johnson's administration throughout the campaign among the Republican papers of the State than the Ogdensburg Daily Journal, the leading Republican organ in the northern part of the State. Ogdensburg Daily Journal, Oct. 3, 5, 16, 1865.

"Buffalo Daily Courier, Oct. 20, 1865; Albany Evening Journal, Oct. 20, 1865 . 
moneyed interests were acquiring in it forced the Republican papers to repel attack on several occasions. The general charges against the legislature furnished a considerable item in the résumé of the Democratic campaign arguments immediately prior to the election. ${ }^{\mathrm{P}}$

Early in the campaign the political situation in the State had appeared from the viewpoint of an outsider as a series of petty party quarrels. ${ }^{2}$ This opinion was fully merited. In each section of the State the chief editorial attention was given to the conduct of quarrels with pet enemies. The Buffalo Express tore at its Democratic neighbor the Buffalo Daily Courier; the Syracuse Daily Journal carried on a pithy war with the Albany Argus and incidentally with the Syracuse Daily Courier and the Rochester Daily Union and Advertiser; the Binghamton Daily Republican was very bitter in its constant bickerings with the Elmira Gazette, and between the ancient editorial enemies of New York City the usual exchange of incivilities occurred. Exactly why the campaign descended so low journalistically is difficult to determine. It may have been due to the lack of decided leaders in both parties, to the general popular character of the milizary candidates or to the removal of the Democratic policies by the close of the war.

The campaign was closed in a whirlwind of personal defamation directed against the candidates on both tickets. The Democrats had the advantage there, for in addition to the charges against Generals Barlow and Barnum, they had been able to unearth a scandal in con-

\footnotetext{
${ }^{\prime}$ Cf. James Parton, How' New l'ork City is Governed (Boston, I866), passim. See article on the New York Legislature, Harper's Weekly, vol. ix, p. 210, April 8, 1865.

'Springfield K'cpublican, quoted in Buffalo Daily' Couvier, Oct. 3, 1865.
} 
nection with the name of $\mathrm{J}$. Platt Goodsell, candidate on the Union ticket for state engineer. The only basis for their charges was collateral evicience in connection with malfeasance on the part of John C. Mather, a Democratic canal commissioner. ${ }^{x}$ On the Democratic ticket Slocum was forced to bear the brunt of Radical attack, in rep?y to which the Democrats published a list of prominent men who had endorsed Slocum; among these names appear those of Generals Sherman, Dix, Sickles, Cochrane, Bartlett and Frank P. Blair; Montgomery Blair, Judge Barlow, Judge Edmonds and Lieutenant-Governor Campbell. ${ }^{2}$ Surely an imposing array.

But if the Democratic candidates proved not so vulnerable as their Unionist rivals such was not the case with the Democratic record, which the Radical journals took good care should not be forgotten. "It is impossible," said the Ogdensburg Daily Journal,

that a party which only six months ago, with the record of its whole life before it, denounced Andrew Johnson as a drunken boor, and Abraham Lincoln as a backwoods buffoon, should now entertain a high appreciation of President Johnson. Neither do the men who opposed the war, calling it a failure, entertain any more love for it now than they did a year ago for our brave soldiers. They pass empty resolutions of thanks now to escape the responsibility of the past and nominate such as are willing to lend themselves to a base purpose, in hope of dividing the Union party for the purpose of securing an easy victory hereafter. ${ }^{3}$

${ }^{1}$ Utica Morning Herald. Oct. 24, 1865. Goodsell was proven to have had no connection with the matter.

'Syracuse Daily Courier and Inion. Nov. 7. 1865 .

${ }^{3}$ Ogdensburg Daily Journal, Oct. 24. I865; Syracuse Daily Standard, Nov. 2, 1865 . The letters of Petroleum V. Nasby served with peculiar force in this and later campaigns. It is difficult to turn the shafts of ridicule. As such it is instructive to view the attack made 
However, the prejudice caused by the disloyal course of the Democrats throughout the war proved too strong for success. The election took place on November $7^{\text {th }}$.

upon the Democratic position, after the October elections of 1865 . Letter from Petroleum V. Nasby, after the October elections:

“Ohio, Ablishn! Pennsylvania, Ablishn! Ablishn and nigger suffrage to boot! Injiany. Ablishner than ever! Noo Gersey, not exactly Ablishn, but approachin thereunto.

Such is the encouragin news I red in the noospapers this mornin! Sich is the result of labers Hercoolian, in the above named States. .. The pure Dimokrasy probably will carry Noo York; but what consolation is that to me? The two parties, the old, anshent Dimokrasy and the Ablish, run a race into the realm of Radikalism, and the Dimokrasy beat them over a length. . . With a platform standing by Johnson, endorsin his anti-slavery noshuns, his Suthern oppreshun noshuns, his hanging of Mrs. Surratt, et settery, and on that platform a sojer who never voted a Dimokratil ticket in his life, who went into the war a Radikie Ablishnist, and who come out a Radikler Ablishnist, I don't know that I have much to choose atween 'em.

Last week I was invited in to a county in Noo York to address a Dimokratik meetin. I accepted (es my expenses were paid which is cheaper and better board than I get at the groceries to hum), and akkordingly I went. I commenst deliverin the speech I hed yoosed all through the state of Noo Gersey. I commenst aboosin the nigger. when the cheerman interrupted me. 'Well,' sez I, 'wat is it?' rather angrily for I git warmed up and sweatin, and don't like to be interrupted. 'Why,' said he, 'our Constitoshin allows a nigger that's got $\$ 250$ to vote, and most ov em hev that sum, and we make it a point to sekoor em.' 'They're a d-d site better off then most of us white Dimokrats in Noo Gersey, 'retorted 1, a droppin the nigger and goin agin President Jolnnson. 'Stop,' whispered he. 'our platform endorses President Johnson.' 'Thunder,' remarked I, droppin President Johnson and slidin easily into a vigorous denunsiation of the war. 'Good God!' sez the cheerman, 'stop! our platform endorses the war.' I sed nuthin this time, but commenst denounsin the debt. 'Hold,' sed the cheerman, 'easy-easy-our platform backs up the debt.' 'Well then,' sed $I$, in a rage, 'why in blazis didn't yoo send me a copy of your platform when you wantid me to address yoo? Go to thunder and make yoor own speeches;' and I stawked off the platform. Time wuz wen wun speech wood do a man awl over the North, now yoo hev to hev a different wun fur evry State, wich makes it impossible fur me to travil fer wun effort per season is enuff fur me.", 
When the returns came in, it was found that the Union Party had strong majorities. Major-General Slocum received 272,793 against 300,46I for Major-General Barlow, giving the latter a 27.46 I majority. The Unionists received a vastly increased majority in the legislature.

The World could not accept defeat without dire prophecy.

We have no desire to count our wounds, nor to conceal them. They are the witnesses of a manly struggle, against odds. Nor would we conceal their disastrous consequences, not so much to the party, which will outlive and outlast and bring to the dust these victors of to-day, and whose principles being true are imperishable, but, in the defeat of the Democratic party, President Johnson's plan for the immediate restoration of the Union is defeated also. The tide of fanaticism which has swept over the nation, engulfing its laws, its liberties, and its material prosperity, though visibly abating, has not yet reached its ebb. Every hour it falls, and the time cannot be far distant when the people of the North, so long led through deep waters by blind guides, will search for dry land and other leaders. That day will see the triumpl of Democratic principles and of those who have faithfully upheld them. ${ }^{2}$

Greeley complacently interpreted the Union victory to mean that "the pcople "rant our internal differences so settled that they can never return to trouble the nation's peace." 3 "If they were honest in pretending to support

'Tribune Almanac, I866, p. 62; New York Tribune, Nov. 8-9, 1865; New York World. Nov. 8-0, i865; Appleton's Ann. Cyc., 1865, p. 515:

Senate. House. Joint Ballot.

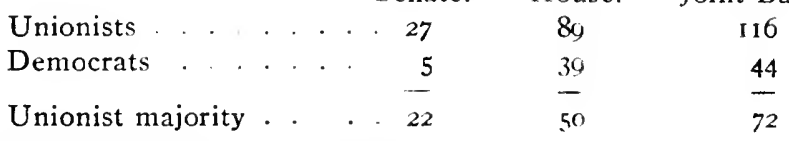

${ }^{2}$ New York World, Nov. 8, 1865.

${ }^{3}$ New York Tribune, Nov. 9, 1865. 
the President, they can give that support out of office as well as in," "was the consolation offered to the Democrats by Raymond. Ellis H. Roberts believed that President Johnson would stand by "the voice of the people just uttered," " but he did not know whereof he spoke. To William Stuart the Union victory meant that the young men of the State and the boys in blue had lost faith in the promises of Democracy ${ }^{3}$ or, as the Ogdensburg Daily Journal put it, " neither the people nor the soldiers can be allured into the support of a soldier who will suffer his name to be used to revive the fortunes of Copperhead politicians." 4 The Rochester Daily Democrat diagnosed the case as follows: "Besides its disloyalty ... the Democracy in this last campaign had to carry the burden of a hypocrisy so transparent as to be visible to the dullest observation and so gross as to disgust even the hardened politicians." The Albany Evoning Journal was the most far-sighted in its vision of the results of the Democratic defeat. The Evening Joumal believed the six following points settled: I. the Democratic defeat established the fate of the northern secessionists, 2. the election pronounced the terms upon which the work of reorganization must proceed, 3 . it clisposed of at once and forever the outcry against the public debt, 4. it gave a substantial endorsement to the national administration, 5. it secured a firm and decided course on the part of the majority in Congress, 6. and, lastly, it proved to the world the stability of republican institutions. ${ }^{5}$

Among the up-State Democratic papers, with one

${ }^{1}$ New York Times, Nov. 8, 1865.

${ }^{2}$ Utica Morning Herald, Nov. 9, 1865.

${ }^{3}$ Binghamton Daily Republican, Nov. Io, 1865.

${ }^{4}$ Ogdensburg Daily Journal. Nov. I I, I865.

${ }^{5}$ Albany Evening Jonrnal. Nov. 8, I865. 
prominent exception, a disposition was manifested to "accept the result with patience and magnanimity." I The Daily Union and Advertiser of Rochester had made its plea for organization all through the campaign, and to lack of such it attributed its party defeat. ${ }^{2}$ The Utica Daily Observer saw Johnson already in the power of Congress. $^{3}$ But it remained for Mr. Halstead, of the Syracuse Daily Courier and Union, to explain the method by which Horace Greeley was able to defeat Democracy.

His troops all over the State wheeled into line, and plan of attack was matured ... issues disregarded ... the ins drilled ...the outs promised... the employee threatened ... the corrupt bribed ... the timid intimidated ... the boards of inspectors instructed, betting resorted to ... bond holders marshalled, and the money bags scattered around the polls .. hence the Democracy crushed. ${ }^{4}$

The question naturally presents itself in ending a study of the campaign of 1865 -what were the causes for this era of petty politics? No great question of national politics arose, outside of the President's policy. The Unionists and the disciples of Seymour guaranteed the payment of the national debt. The more delicate problems of Reconstruction were only just beginning to come upon the national horizon. President Johnson had not yet divorced his party. The questions of international relations resulting from the Rebellion were not then clearly understood by the masses. With the above questions not actively before the public, with popular

'Albany Argus, Nov. 8, 1865.

${ }^{2}$ Rochester Daily Union and Advertiser, Nov. 8, 1865.

${ }^{3}$ Utica Daily Observer, Nov. 8, I865.

'Syracuse Courier and Union, Nov. 9, 1865. 
soldiers on each ticket, with no specific matter of legislative venality or party mal-administration to inflame the public, and with the mental reaction setting in after four years of tension over the most vital of national problems, it does not appear so strange that the arts of the ward heeler were requisitioned to stimulate a false interest in the campaign to the detriment of brave men's characters. 


\section{CHAPTER IV}

Attitude of New York Towards Reconstruction

The party platforms of New York for i 866 very clearly reflected the movements in national politics. We may simply suggest these movements as a background for the political situation in New York in 1866 . Under the leadership of Charles Sumner, of Massachusetts, and Thaddeus Stevens, of Pennsylvania, the Radical Republicans shortly after the opening of the first session of the Thirty-Ninth Congress were at war with the President over reconstruction measures.

As an immediate result of the President's veto ${ }^{1}$ of the bill to enlarge the powers of the Freedman's Bureau, Johnson disgraced himself in his famous White House speech of February 2210. ${ }^{3}$ The tide of public feeling against Johnson rose so rapidly that upon his veto of the Civil Rights Bill, the Senate repassed it with the necessary two-thirds vote on April 6th; the House doing so three days later. ${ }^{+}$Parallel with the action of Congress

${ }^{1}$ While Johnson proved obstinate in his course, it is believed that, at first, he was influenced directly by Seward, the Blairs, and Preston King, late Senator of New York. Horks of Charles Sumner, vol. xi, p. I8. Blaine, Twenty Years of Congress, vol. ii, pp. 66-ro8. Rhodes, vol. ii, p. 447 ; vol. v, p. 588.

${ }^{2}$ Reported by Senator Trumbull, of Illinois, on Jan. II, I866. The Freedman's Bureau was originally established by an act of March 3, I 865, approved by Lincoln.

${ }^{3}$ Appleton's Ann. Cyclopedia, 1866.

'Globe, pt. iv, Ist Sess., 39th Cong., p. 535.

$8 \mathrm{I}]$ 
on the Civil Rights Bill, the Fourteenth Amendment had its inception, January 3 I, I866, in the form of a report by Stevens to the House on a proposed Constitutional Amendment which at length passed the Senate, June 8th, and the House five days later. ${ }^{\mathrm{T}}$ Tennessee, upon her acceptance of the Thirteenth and Fourteenth Amendments, after having declared the Ordinance of Secession and the war debt roid, was restored to her former place in the Union. ${ }^{2}$

Attention is now directed to the central political motif in the politics of I866, namely, the concerted movement to organize a new party on the platform of Johnson's policy. National expression was given to this movement, shortly after the passage of the Civil Rights Bill, in the plan for the National Union Convention held at Philadelphia on August I4, I 866.3 The aim of the convention was to join conservative Republicans and Democrats in the North with the moderate men of the South. ${ }^{4}$ With the exception of Arizona, Montana and Utah, every State and Territory was represented. General John A. Dix, of New York, was chosen for temporary chairman, and Senator James R. Doolittle, of Wisconsin, for president of the convention. A great display of amiability was made in various ways between

${ }^{1}$ Globe, pt. iv, ist Sess., 39th Cong., p. 535.

${ }^{3}$ Ibid., I895, p. 4007.

${ }^{3}$ The Convention was held in a huge wigwam with a seating capacity of 15,000 .

${ }^{4}$ F. W. Seward, William H. Seward, an Autobiography' (New York, I89I), vol. iii, p. 339. The Southern delegates belonged to the moderate class for the most part. That is, those who had not stood for secession originally, but had decided to stand by their States. When they came together, Raymond remarked that "the general feeling was one of delight at renewing former political, social and personal relations with the men of the north." 
men who, and sections which, had been notoriously at enmity. ${ }^{x}$

The Democrats in the Philadelphia Convention realized the necessity for a conciliatory attitude toward the Republicans in order to win the fall election. Hence two of the most noted Copperheads, Fernando $\mathrm{Wood}^{2}$ and Vallandigham, who had been accredited as delegates, were asked to withdraw. The leaders saw that, if seated, they would tinge the convention with a Copperhead hue and the convention would go for naught. Both withdrew, when the situation was explained, Wood gracefully, Vallandigham not until pressure was used.

The Philadelphia Convention was directed largely by the New York triumvirate, William H. Seward, Thurlow IVeed and Henry J. Raymond; the latter a doubting Thomas as to the wisdom of such a convention. Raymond was first approached in regard to the convention by Thurlow Weed. Shortly after, the call for a convention appeared in the newspapers. It was signed "by a joint committee composed of members of the Johnson Committee and of the Democratic Committee." Naturally a call so signed caused clistrust to arise in the North and in Congress. Several days later Seward met Raymond and casually remarked that it was understood that Raymond "would write the address." To clinch Raymond in its favor Seward took him in to see the

'Nast has a caricature in Harper's Weekly of the northern and southern delegates walking into the convention arm in arm, uttering such sentiments as "Charity covereth all," "Oh, blessed hour," etc. They are accompanied by a $\operatorname{dog}$ and a cat, arm in arm, also a cat and a rat, arm in arm. Harper's Heekly, Sept. I, I866. Cf. also, The Nation, Aug. 23, 1866, p. 152. New York World, Aug. 14-15, I866.

${ }^{2}$ New York Herald, Aug. 13, 1866. New York Horld, Aug. 14-15, I866. Wood wrote a letter at the first suggestion that he was unwelcome, in which he claimed that he had the welfare of the Union and the convention at heart. 
President. Johnson said he "wanted Congress to restore the Union" and to "have this matter settled within the Union Party." He thought that it would be a great step gained "and that it would have a salutary effect on public sentiment.” ${ }_{\text {I }}$ The President's wish was granted in so far as the convention was able, for the resolutions were an emphatic endorsement of Johnson's policy.

It would have been well for Raymond had his doubts kept him from participation in the convention, as he proved the first victim of this attempt to found a new party on Johnson's policy. The address made by Raymond, in spite of the great enthusiasn with which the convention received it, proved his political Waterloo. ${ }^{2}$ The address did not aid the Presicient, while it sounded Raymond's political death-knell. ${ }^{3}$ From this time, his

${ }^{1} \mathrm{~F}$. W. Seward, Seward, op. cit., pp. 337-338.

${ }^{2}$ New York World, Aug. 17, I866. Maverick, Rammond and New York Journalism (Hartiord, Conn., I870), p. I72. The points Raymond made in his address follow: I. It should be remembered that the war is ended and that the nation is at peace. 2. He argued for the necessity of accepting the legitimate political consequences of the war, and (3) insisted un the importance of accurately understanding the real character of the war. 4. It was declared that the United States Constitution remained exactly the same as before the war; and that only since the war had ceased that " the right of conquest and confiscation, the right to abrogate all existing governments, institutions and laws, and to subject the territory conquered and its inhabitants to such laws, regulations, and deprivations as the legislative department of the government may see fit to impose; had been urged in favor of one department of the General Government." 5. Lastly, he gave an elaborate argument against Congress for its opposition to the President. He made the point, that it was unjust to refuse to ten states a representative in Congress, because those states were not in rebellion, but were one and all "in an attitude of loyalty towards the government and of sworn allegiance to the Constitution of the United States."

"Harper's Weekly, which belittled the results of the Philadelphia Convention, said of Mr. Raymond's address, that "it contains nothing new, and states nothing old with new force." Harper's Weekly, Sept. I, I866, p. 546 . 
name was dropped as one of the Republican leaders. His pleasant associations with them ceased. Shortly afterward, an unauthorized meeting of the Radicals on the Republican National Committee was called at Philadelphia; these "bolters" removed him from the chairmanship.' This action was approved by the next State Convention. ${ }^{2}$ Subsequent to the informal call for a meeting at Philadelphia, Raymond, as chairman, issued a formal call for a meeting at the Astor House. ${ }^{3}$ Governor Ward, of New Jersey, presuming on his prominence, essayed to answer Raymond's call in a public letter, in which he stated that Raymond had forfeited the chairmanship because of his political apostasy. To this Raymond issued a civilly contemptuous reply, stating that he had no desire to hold the chairmanship against the wishes of its members. Only seven attended the meeting at the Astor House. ${ }^{4}$ Raymond soon realized his false move and endeavored to retrieve it, but was never able to rehabilitate himself in his former political station. ${ }^{5}$ At this day, when the bitter feeling of the Reconstruction period is largely allayed, it is difficult to see what there was in Raymond's speech that so completely shut him from his party.

Another difficulty beset Raymond's pathway, as he was accused of having turned Copperhead. This accusation was set at rest by a letter ${ }^{6}$ which he had written to Ransom Balcom, of Binghamton, on July I7, I866, be-

${ }^{1}$ New York Times, Sept. 8, I866. New York World, Sept. 4, I866. He was later removed from the committee.

${ }^{2}$ New York Tribune, Sept. 6, I866. New York Herald, Sept. 6, 1866.

${ }^{3}$ New York Herald, Sept. 4, 1866.

${ }^{4}$ New York World, Aug. 31, I 866.

${ }^{5}$ New York World, Sept. 28, 1866.

${ }^{6}$ Albany Evening Journal, Oct. 8, 1866. 
fore the Philadelphia Convention. He wrote: "I think it is not unlikely that the Philadelphia Convention may have a wholesome influence on our State Convention and make it somewhat more moderate than it would be otherwise. But it is not likely to disturb the integrity or the ascendency of the Union Party." ' Raymond, at length awakening to a full recognition of Johnson's character, issued this statement: "We have tried very hard to hold our original faith in his personal honesty, and to attribute his disastrous action to errors of judgment and infirmities of temper. The struggle has often been difficult, and we maintain it no longer." 2 Mr. Raymond served but one term in Congress. He was offered the renomination in September of 1866 by the Conservative Republicans, the names of a long list of prominent citizens appearing upon the petition, but the nomination was refused. Raymond gave his reasons for declining the nomination in a strong, dignified justification of himself and his attitude in Congress. ${ }^{3}$ Horace Greeley, who in I866 represented the extreme Northern sentiment, and whose paper, the Tribune, was the mouthpiece of the party which cast out Raymond, took occasion to write a caustic editorial on Raymond's letter of declination. ${ }^{4}$ The World in a critical article was inclined to censure Raymond for his unstable position in the attempt to prove his true Republicanism. ${ }^{5}$ Among his editorial colleagues throughout the State, Raymond found no sympathy. ${ }^{6}$

${ }^{1}$ Cf. Maverick, Raymond, pp. 173, 190. "Ibid., p. I74.

${ }^{3}$ New York Times, Sept. 27, I866. Maverick, p. 190.

${ }^{4}$ New York Tribune, Sept. 28, 1866.

${ }^{5}$ New York World, Sept. 28, 1866. Binghampton Daily Republican, Sept. 29, I 866.

${ }^{6}$ Syracuse Daily Journal, Sept. 28, 1866. Carroll E. Smith remarked: "His Congressional career had been neither brilliant nor useful enough to make his re-election a thing to be desired." 
The movement to organize a new party on the platform of Johnson's policy failed to produce the results which were expected from it. This caused President Johnson to tour the country in order to turn the Congressional elections in his favor. The occasion for the tour was the laying of a cornerstone at Chicago, September 5, I866, for a memorial to Stephen A. Douglas. The trip was jocularly called "swinging-a-round-the-circle." I The Presidential party created but little unfavorable comment in the East, ${ }^{2}$ and the crowds were not especially discourteous, but in the western cities the throng had little respect. At Cleveland and other places in the West, Johnson, stinging under the charge of traitor to his party, duplicated his unfortunate address of February $22 \mathrm{nd}$, even condescending to maudlin repartee with the crowd. ${ }^{3}$ At St. Louis, Johnson capped the climax of his journey when he accused the Unionists in Congress of liaving practically planned the New Orleans massacre. ${ }^{4}$ $\mathrm{He}$ also indulged in a muddled invective about Judas, Christ and Moses. ${ }^{5}$ Even while the tour was in progress the press and various public bodies expressed disapprobation. ${ }^{6}$ The President returned a discomfited and defeated man.

The second noteworthy victim of the President's attempt to organize a new party with his policy as a plat-

' James Russell Lowell, Political Essays, p. 296, speaks of it as an " advertising tour of a policy in want of a party."

"New York Tribune, Aug. 29, 1866. New York Herald, Sept. 4, 1866.

${ }^{3}$ McPherson, op. cit., pp. 134-6. ,Pierce, Sumner, vol. iv, p. 299. Schurs, Carl, The Reminiscences of (New York. I905), vol. iii, p. 243. Petroleum V. Nasby, Swinging round the cirkle (Boston, 1867), p. 89.

'See Appleton's Ann. Cyc., 1866, pp. 454-6.

'See McPherson, pp. I36-140.

${ }^{6}$ New York Times, Sept. 7, 1866. New York Tribune, Sept. 8, 1866. 
form was Seward, a man who deserved much from the Republican Party. Seward remained faithful to his chief and to the policy which Seward had done so much to forward. He considered it his duty to attend the President upon his tour, though he shrank from its "excitements and fatigues." ${ }^{\prime}$ As a result, after the ill-fated trip "to eulogize Douglas and exhibit Johnson," " Seward received ridicule and reproach from all sides, ${ }^{3}$ but he had not parted from his principles. He was largely the victim of circumstances in that he believed it his duty, in addition to his ambition, to control international relations, as well as to help defend a policy in the inception of which he had aided. ${ }^{4}$ Seward absolutely refused to defend himself against the charges of his enemies. ${ }^{5}$ It is considered by his biographers that Seward has been too severely condemned for his part in Reconstruction, especially when one considers the fact that he had no essential responsibility for the President's acts.

Before going further it is necessary to explain the bewildering political terminology which existed in 1866 , due to the break-up of old party lines as expressed in the Philadelphia Convention, and to state the plan which will be followed in the use of these names. Republicans were often referred to as Unionists or Union Republicans, i.e. those Republicans who had stood for Union throughout the Civil War; as Radicals, i. e. those Republicans who desired to impose severe conditions on the Southern

' F. W. Seward, Sezeard, vol. iii, p. 339.

"Bancroft, Life of Sezeard (New York, 1900), vol. ii, p. 462.

${ }^{3}$ Lowell, Political Essaj's, p. 29o. Pierce, Sumner, vol. iv, p. 360. The Nation, Sept. 20, I866, vol. iii, p. 234. Harper's Weekly, Sept. 22, I866, p. 594.

${ }^{4}$ Bancroft, Seward, op. cit., p. 436.

${ }^{5}$ Ibid., vol. iii. Letter of Oct. 8, г 866. 
States preliminary to their re-entering the Union; and as Conservatives, or Conservative Unionists, $i$. e. those Republicans who, contrasted with the Radicals, believed that a conciliatory course should be taken relative to Reconstruction. As the Radical wing of the Republican Party dominated the party councils up to I868, the Republicans were more frequently referred to as Radicals, although the editorial writers were generally lapsing back to the term Republicans as early as 1866 . When in I868 the Conservative element succeeded in counteracting the infuence of the Radical wing of the Republican Party, the term Union, which was no longer needed, was dropped.' The Democratic terminology did not lead into such a maze. In this period the term Democrat was in general use. Nevertheless one finds reference to Copperheads, $i$. $e$. northern Democrats who opposed the War; and War Democrats, i. e. Democrats who joined with the Union Party to put down the Rebellion.

To avoid confusion in the following pages the term Republicans will be used to designate both factions in the party when in contrast with the Democrats. If it is found necessary to differentiate between Republicans, the terms Radical and Conservative will be used with the above meanings. There were, of course, Democrats who were radical in their opinions and those who were conservative. But whether radically or conservatively inclined, the matter was personal rather than factional. Hence the term Democrat will be used without differentiation, except where it is necessary to refer to Copperheads or War Democrats.

As the Philadelphia Convention was the national ex-

${ }^{1}$ Cf. supra, pp. 55-56, footnote 6. 
pression of the movement to organize a new party on the platform of the President's policy, so the preliminary State convention of the Conservatives and Democrats of New York, held ${ }^{1}$ at Saratoga previous to the Philadelphia Convention, was the first State expression of the movement. The Convention, at which the Democratic and Conservative elements were about evenly divided, ${ }^{2}$ was largely attended. ${ }^{3}$ Homer A. Nelson was elected temporary chairman. while the forces of Thurlow Weed dominated the meeting. ${ }^{4}$ The purpose of the convention was to unite sentiment and select delegates to the Philadelphia Convention. On the whole the convention was harmonious, with the exception of considerable confusion caused by the claims of two rival sets of delegates from Kings and Westchester counties. ${ }^{5}$ An attempt was made by Mr. E. O. Perrin to force the New York relegation to vote at Philadelphia as a unit, but his motion was tabled. In addition to the district delegates, eight delegates-at-large were appointed to the Philadelphia Convention, including John A. Dix, Henry J. Raymond, Samuel J. Tilden and Sanford E. Church. ${ }^{6}$ The resolutions of the Saratoga Convention were brief, but emphatic. They fully endorsed the President's policy, and

${ }^{1}$ The convention met on Aug. 9. I866.

${ }^{2}$ The Tribune claimed that the Democrats greatly outnumbered those of Republican antecedents. This, however, was stated just contrariwise by the World. New York Tribune, Aug. 10, 1366. New York World, Aug. I0, 1866.

"Six hundred delegates were present.

'New York Tribune, Aug. I0, I866.

"The difficulty was settled by a tacit understanding that in case of contest both sets of returns would be admitted. New York Herald, Ang. 10, 1866.

'New York World, Aug. 10, 1866. The other delegates-at-large were Charles G. Myers, H. L. Comstock, William Kelly, and Hiram Denis. 
decried the action of Congress. ${ }^{\mathrm{I}}$ The fact that they expressed joy at the restoration of Tennessee, which was a Congressional act, would seem to be inconsistent.

The Philadelphia Convention was the most important of the four national conventions held in the summer and fall of $1866 .^{2}$ The election for Representatives and the control of the various State legislatures assumed the character of a national election. The Republicans of New York were the first to select candidates for the fall election. ${ }^{3}$ The convention which was held at Syracuse, September 5, I866, was remarkable for its "singular harmony and enthusiasm." 4 A contest took place

'New York Trobune, Aug. I0, 1866.

${ }^{2} \mathrm{~A}$ second convention was held in Philadelphia on Sept. 3, I866, by the Radicals and Southern Loyalists. Although one should be cautious in accepting the Herald's statement, it is interesting to note its comment. The Herald called it "The Nigger-Worshippers Convention," and said that "such an aggregation of the freaks of nature. physically and mentally, in the shape of humanity, was never seen before." New York Herald, Sept. 4-7, 1866. The New York World, Sept. 4-7, 1866, was equally severe on "The Bogus Southern Convention." However, Harper's Weekly and the Independent were ontspoken in their praise of the Southern Loyalist Convention. Harper's Weekly, Sept. 22, 1866. The Independent, Sept. I3, 20, I866. The so-called Johnson Soldiers' Convention was held at Cleveland on Sept. 17, 1866. The Nation. Sept. 20, 1866, p. 22r: "Cleveland seems to have given the Military Johnson Convention, even a colder reception than Philadelphia gave its greater prototype, the Convention of the 14th of August . . The prominent men are Gen. Custer, Gen. Steedman and Gen. Gordon Granger. The Convention contains many men who 'didn't go into this war to iree the nigger,' many who 'always found the Southerners they met to be perfect Gentlemen'... and very many men who, to tell the plain truth, are shameless and unprincipled office hunters and bad specimens of our worst class of politicians, men whom politics took into the army and who now seek to trade upon their uniforms." To counteract the effect of the Cleveland Convention, a Radical Soldiers' and Sailors' Convention was held at Pittsburg, which the World characterized as "A Feast of Buncombe and a Flow of Bile." New York World, Sept. 26, 1866 .

"New York Times, Sept. 5-6, I866.

'Harper's Weekly, Sept. 22, 1866, p. 594. The meeting was held in 
over the choice of the temporary chairman. Charles $\mathrm{H}$. Van Wyck was selected, at length, over Lyman Tremaine. The latter, however. was chosen as permanent president of the convention. Horace Greeley was the leading spirit. The Times spoke of him as "the chief engineer. who apparently intends to run the machine on his own hook." " The great bone of contention among the delegates was not the question of Federal Reconstruction. but the reconstruction of the State ticket. The middle and western portions of the State urged the renomination of the old ticket, while the eastern and New York delegations demanded a change. Senator Ezra Cornell was the only candidate for Governor Fenton's position. He, however, gracefully withdrew on learning that the majority were in favor of Fenton. ${ }^{2}$ In connection with the nominations for lieutenant-governor, land commissioner, and state prison inspector, there was a loud clamor for new men. ${ }^{3}$ This demand for new men was based, not only on the ground that it would strengthen the ticket, but also that the present ticket was sectional,

Weiting Hall, which was decorated with various caricatures. On the left of the platform was a caricature of Johnson by Nast; the President was seated with one eye turned malignantly upon the Convention, while the other was watching the pardons as they flew from his hands. New York Tribune, Sept. 6, 1866. The ticket was as follows:

Governor-Reuben E. Fenton, Chautauqua.

Lieut.-Governor-Stewart L. Woodford, Kings.

Canal Commissioner-Stephen T. Hoyt, Steuben.

Prison Inspector-John Hammond, Essex.

New York Herald, Sept. 6, 1866.

"The Loyal League" held a Convention in Syracuse on the same day as the Republicans. This meeting was addressed by Lieut.-Governor Alvord and others. It exerted a strong influence in favor of the renomination of Reuben Fenton and Alvord. New York Times, Sept. 5, 1866 .

${ }^{1}$ New York Times, Sept. 5, 1866.

2New York Tribune, Sept. 6, 1866.

${ }^{3} \mathrm{New}$ York Herald, Sept. 6. 1866. 
excluding the southern counties and New York City. This demand was pointedly followed by the westerners' retort that the southern counties never gave majorities for the ticket. Considerable feeling was displayed over the dropping of Lieutenant-Governor Alvord, of Syracuse, for General Stewart L. Woodford, ${ }^{1}$ of Kings county. Mr. Andrews, of Onondaga, urged the renomination of the former on the ground that he came from "one of the seats of power of the Republican party; ${ }^{2}$ and that he should not be discriminated against when Governor Fenton had received such unanimous support. William A. Wheeler, of Franklin, who later became Vice-President, was also suggested for lieutenant-governor, but his name was withdrawn. General Woodford was a young politician, rising in the party's favor because of his oratorical ability. He was supported by the entire New York and Brooklyn delegations, being the choice of the western delegates second to Alvort. ${ }^{3}$

${ }^{1}$ Encyclopedia of Contemporary Biography of New' York. pp. 106-9. Spoke of him as a brave soldier and capable lawyer.

"New York Times, Sept. 5, I866. "They do not disguise the fact that they want him on the ticket mainly for his oratorical powers in stumping the State."

${ }^{3}$ New York Tribune, Sept. 6, I866. The Republican State Central Committee was appointed as follows:

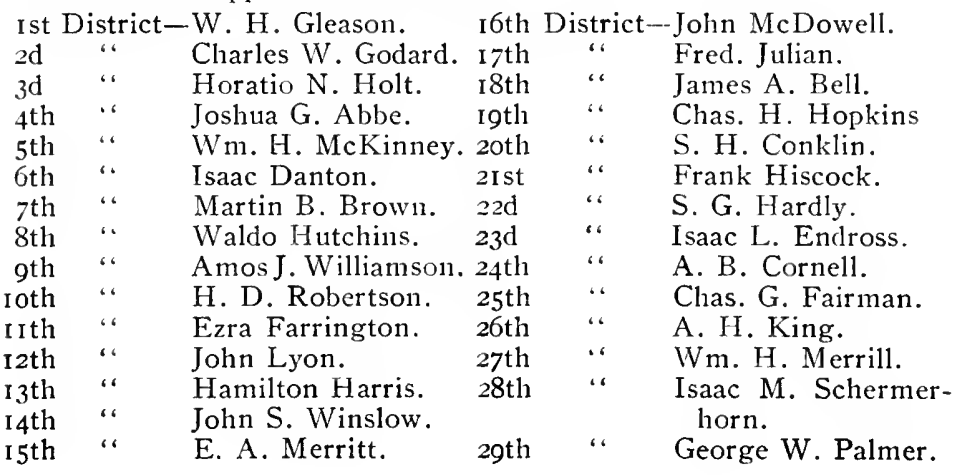


After the result had been made known, the Republican editors of the State journals appear to have accepted the predominance of the New York City politicians in the convention without protest. The western organs which had been loudest for the nomination of men from the central and western portions of the State, like welltrained soldiers, fell meekly into line, praising the virtues of the new candidates. The Syracuse Daily Standard cites the clever exhibition of sacrifice on the altar of party, which Lieutenant-Governor Alvord made, as an evidence of Republican loyalty. "I am delighted," said Alvord, "to lay my personal ambitions on the altar of my country and train in the ranks as well as at the head." " The Daily Journal, of Ogdensburg, recognized "the will of the people ${ }^{2}$ in the nominations at Syracuse. The up-State Democratic organs were more prone to sympathize with the victims of the unfeeling conduct of the Republican convention in casting out its old loves for new ones. The Daily Courier. of Buffalo, believed that the Republicans had weakened their ticket by dropping Alvord and Bruce. It considered Fenton the strongest man on the ticket. ${ }^{3}$ The Albany Argus believed that the nomination of Fenton kept strong men from the field. It eulogized Alvord as follows: "No man has followed his party with more cringing subserviency. He brought into play all the wiles and arts of a cunning wirepuller, and was ready to eat any amount of dirt the political doctors thought necessary to prescribe. Commissioner Bruce is treated in a similar unceremonious manner." 4

'Syracuse Daily Standard, Sept. 7, I866.

2 Ogdensburg Daily Journal, Sept. 10, 1866.

${ }^{3}$ Buffalo Daily Courier, Sept. 7, 1866.

4Albany Argus, Sept. 7, 1866. 
The platform, as predicted, was a strong Radical document. "It is to be a platform on which no Johnson man can, by any possibility, stand upright," said Charles Spencer." The resolutions claimed that "Every political, social, and industrial interest of the country, as well as the most earnest desire of every generous and patriotic heart, imperatively demand the speediest restoration of the Union which is consistent with constitutional justice and national safety." = Asserting the perpetuity of the Union and the nullity of secession, the statement was made that

while the constitutional authority of the Federal Government can in no wise be impaired by the acts of the State or its people, a State may, by rebellion and war on its part, or treason on the part of its inhabitants, or by the abnegation of its loyal State Government, and the creation and maintenance of one alien and hostile in form, so far in fact rupture its relations to the Union as to suspend its power to exercise the right and privileges which it possessed under the Constitution. That against such rebelling State, the Federal Government may wage war for its subjection ... and when that end is accomplished it belongs to the legislative power of the Government to determine at what time the State by the establishment of a government, republican in form under the Constitution, and the complete abandonment of its rebellion. and the return to loyalty of its inhabitants, may safely resume the exercise of its rights and privileges under the Constitution which have been inert and suspended by its wrong. ${ }^{3}$

${ }^{1}$ The feeling against Johnson and the Conservatives was very bitter. "The delegates fairly boil over with rage. When asked what makes them so vindictive and abusive in language, they fly into a passion and reply, 'Taik about personal abuse! Who but Johnson and Seward are indulging in abuse? They, not we, are the parties using abusive epithets.' They then blow out with all the epithets they can form out of the English language, proving the very opposite to that which they claim." New York Herald, Sept. 6, i866.

"New York Tribune, Sept. 6, 1866.

${ }^{3}$ Ibid. 
The platform denied the doctrines that the States while in rebellion had kept all constitutional rights "perfect and unimpaired," and were themselves to judge when they were in proper condition to resume enjoyment of those rights. Also it denied "that the President is alone sole judge of the period when such suspension shall be at an end."

The convention approved the Reconstruction policy of Congress. It declared that ten Southern States were unrepresented, because of their refusal

to accede to certain conditions including the ratification of the constitutional amendment of emancipation. . . And that their claim to enter Congress before that change is acknowledged, is a demand that a bloody attempt to dissolve the Union shall be rewarded with increased representation of political power. That the President of the United States, in denouncing as unconstitutionally incompetent the Congress whose lawful authority he has officially recognized, convicts himself of usurpation of power. ${ }^{1}$

It may thus be seen that the Republican Convention at Syracuse, dominated by the Radicals, was in keeping with the current in national politics.

General Barlow showed his lack of ill-will by urging the delegates to do all in their power to secure the favor of the soldiers and sailors, who were to meet in convention on September 2I, I866, in the same place. With the passage of a motion by Charles S. Spencer, which provided for a preliminary enrollment of Republicans in the various assembly districts of New York City, ${ }^{2}$ the convention adjourned sine die.

' New York Tribune, Sept. 6, 1866.

${ }^{2}$ New York Herald. Sept. 6, I866. 
The Democrats exulted in the nomination of Fenton. The World said that "if the Democratic party had been allowed to select a candidate for the Republicans, there is hardly a man in the State they would have preferred to Reuben Fenton." " As will be seen, the Conservatives held the key to the election of 1866 . Had the Democrats not alienated the Conservative vote by apparent lack of faith, the prediction of the World might have come true. "Had the Syracuse Convention nominated a man of higher personal standing or more moderate views there would have been some competition for the votes of the Conservative Republicans," said the World, "as it is they are sure to vote the Conservative ticket." " It would appear that time has given Reuben E. Fenton a niche somewhat near that to which he was consigned by the World, when it said: "Mr. Fenton has no hold on the Conservative Republicans. None by. superior abilities and standing, for in these respects he has no hold on anybody; none by the moderation of his character, for he is a spasmodic Radical, as well as a.weak man.", 3

In keeping with the attacks of the radically inclined Republican papers of New York City upon the President, their country cousins were nothing if not severe toward Johnson. "Nothing more is required to arouse popular feeling," said the Albany Evening Journal, "than has already been done by the shameful course of the President and by the contemptible conduct of his conservative followers. All that is needed is to consolidate and direct the sentiment that exists." " The Evening Journal declared that the platform represented "everything for the

' New York World. Sept. 7, i866.

${ }^{2}$ Ibid. $\quad{ }^{3}$ Ibid.

"Albany Evening Journal, Sept. 6, I866. 
cause-nothing for men." " To the Rochester Daily Democrat, the only consolation was that Johnson had already sunk so low in public esteem that no further descent seemed possible. ${ }^{2}$ The Buffalo Express saw in the defeat ${ }^{3}$ of "My Policy" by the Radicals of Vermont in their September elections, the harbinger of victory for the Radicals of New York. In the heat of its enthusiasm over the Syracuse platform, the Express dared "the worst assaults of a piebald and corrupt enemy whose controlling impulse is plunder, and whose hopes center in its ability to deceive and cheat the people." 4 The editorials of the Syracuse Daily Joumal and the Utica Morning Herald were so in unison on the results of the Republican convention that they could well have been written by the same hand, rather than by two editors, ${ }^{5}$ both rivals for the editorial leadership of the Republican press up-State. The Utica organ gave perhaps the better characterization of the convention.

The Convention was strong in the character of its members, but stronger still in the fiery earnestness of its convictions, in the entire harmony of its deliberations, in the stern fixedness of its purpose and in the inspiring confidence of complete success. No Convention has exhibited so much spirit, so much vital energy, so much of the moral forces of deepwrought and settled determination. ${ }^{6}$

But even Mr. Roberts could not refrain from rebuking the "reckless demagogism of Mr. Johnson." 7

${ }^{1}$ Albany Evening Journal, Sept. 6, I866.

${ }^{2}$ Rochester Daily Democrat, Sept. 8, 1866.

${ }^{3} 5000$ Radical majority.

'Buffalo Express, Sept. 7. I866.

${ }^{5}$ Carroll E. Smith, of Syracuse Daily Journal.

${ }^{6}$ Ellis H. Roberts, Utica Morning Herald, Sept. 7, 1866.

${ }^{\top}$ Syracuse Daily Journal, Sept. 6, 1866. 
The chief State expression of the movement to build a new party using Johnson's policy as a platform was made at Tweedle Hall, Albany, on September I I, I866. The attempt of the Democrats to outmanewver the Radicals by uniting with the Conservatives and taking the name of the Conservative Union convention was not preeminently successful. The Democrats were glad to receive the benefits to be derived from an alliance with the Conservative element, but they were not willing to "pay the price" entailed in order to assure complete success. Delegates of Democratic antecedents controlled the convention. ${ }^{\mathrm{I}}$ The sophistry by which the Tammany Democrats attempted to justify their seizure of the political plums might be stated thus: had the Radicals nominated a moderate, able man, it would have been well to put in nomination a Conservative to draw up-State Conservative votes, "but against a narrow, bitter Radical, like Fenton, there was no reason in the world why a regular Democrat should not be taken." 2 Under these circumstances, the Democrats could not see that the Conservatives had any cause for dissatisfaction, especially as they were in the minority.

The convention was called to order by Peter Cagger, who had succeeded Dean Richmond. Sanford E. Church, of Orleans, a promising young man whom Tammany chose to honor, was elected temporary chairman. The sentiment before the convention opened was extremely indefinite. ${ }^{3}$ There were tivo sets of delegates from

${ }^{1}$ New York Tribune, Sept. II, 1866. Greeley stated that "two-thirds of the delegates are of the old genuine Copperhead stripe. The other third is made up of office-holding Republicans." New York World. Sept. I3, I866. The World magnanimously admitted that the Conservatives were in the minority.

2New York World, Sept. I3, I866.

${ }^{3}$ New York World, Sept. 12, 1866. 
New York and Brooklyn, representing the Conservatives and the Democrats. They, however, came to an agreement without a contest for seats. ${ }^{\mathrm{I}}$ From the rest of the State, the Democratic and Conservative delegates were about equally divided. ${ }^{2}$

Chief among the candidates for Governor were General John A. Dix; John T. Hoffman, Mayor of New York; General Henry IV. Slocum; Robert H. Pruyn and State Senator Henry C. Murphy. ${ }^{3}$ It was claimed for the latter that he would have been the nominee had Dean Richmond remained alive. ${ }^{4}$ Murphy came up from Brooklyn with a strong band of roughs, who succeeded in giving him a false appearance of strength. But the friends of both Slocum and Murphy soon saw the futility of their candidacy and gracefully retired in favor of Hoffman. 5 The feeling for Dix's candidacy grew stronger as the delegates from the West arrived. The receipt on the first day of the convention of the election returns from Maine, proclaiming a Radical success, produced a strong impression upon the delegates. The need for

'New York Tribune, Sept. I2, I866.

${ }^{2}$ New York Times, Sept. II, 1866 . Among the prominent Conservatives in attendance were: Thurlow Weed, George E. Babcock, of Erie; Mayor Richardison, of Oswego: Wm. E. Dent, of St. Lawrence; Col. Follet, of Chicago; P. H. Eagen, of the Syracuse Standard; Gideon Reynolds, of Rensselaer; Senator Thomas Murphy; W. W. Smith, of Syracuse, and George King. Among the Democratic delegates were: Judge Pratt, of Syracuse; John A. Green, John Mather, General Nivens, A. Oakey Hall, and Surrogate Tucker, of New York. Governor Seymour was absent, as given out, on account of illness.

${ }^{3}$ Sanford E. Church was strongly pressed for Governor, but refused the use of his name. The Western delegates, also, attempted to rally on the names of John Ganson, of Buffalo, and W. C. Fargo, of the American Express Company, but little headway was made.

${ }^{4}$ New York Times, Sept. I I, I866. Better sentiment believed, however, that Richmond would have placed $\mathrm{Dix}$ in nomination without doubt.

${ }^{5}$ New York YJerald. Sept. 12, r856. 
Conservative votes forcibly presented itself. While it was admitted that Dix would draw more Conservative votes than any other man, his opponents contended that such a gain would be more than counterbalanced by Democratic opposition, from those who would not forget his course towards Governor Seymour. ${ }^{\mathrm{I}}$

The trouble over the nomination came chiefly from the extreme Democrats. Backed by thirty thousand dollars, they came to the convention with the determination to nominate Hoffman. ${ }^{2}$ The field narrowed down to Dix and Hoffman. As soon as the Hoffman lobbyists discovered the real strength of Dix, they began a campaign of defamation against him, equal to the bitterness displayed toward Johnson by the Radicals, or the rancour of the Copperheads towards Lincoln. Due to the excessive noise of the Hoffman followers, the country delegates, judging him by his satellites, formed a very unfavorable opinion of him. ${ }^{3}$

In order to work up a stronger sentiment for Hoffman,

${ }^{1}$ New York Herald, Sept. I3, 1866. Dix incurred the especial enmity of the Seymour Democrats by his suppression of two Copperhead newspapers in New York City during the War. The tone of the convention was marred by the untimely death of Dean Richmond, who had so long been the head of the Democratic State organization. In life he was the unquestioned leader of the New York Democracy. Although a politician, he was a man broad in his sympathies, astute in his judgment of people and highly thought of by men of both parties. Upon the first day of the convention, Samuel J. Tilden was called upon to give a eulogy on Richmond. Cf. note on Richmond. F. W. Seward, Life of Seward, vol. iii, p. 339. Harper's Weekly, Sept. i5, I866. New York Herald, Sept. I2, I866.

${ }^{2}$ New York Times, Sept. 12, 1866. The Times suggested that they were as willing to spend it in the convention as on the canvass. Greeley contributed his mite in describing the Democratic hosts. "The lobbies were filled with spectators, most of whom were roughs irom New York and Brooklyn. These fighting characters are the champions of ... Mayor Hoffman and Senator Murphy." New York Tribune, Sept. 12, 1866.

'New York Herald, Sept. I3, I866. New York World, Sept. 13, 1866. 
the New York delegation sparred for time. By a coup d'état, which, if not in accord with ethical rule or parliamentary usage, was startling in its boldness, they accomplished their immediate end, and thus the ultimate goal. On the first morning of the convention a motion to adjourn until the morrow was voted down by an overwhelming majority. The same motion was put in the afternoon session before any business had been transacted, other than the reading of a letter from Morris Franklin, of Queens County, in which he urged the convention to be harmonious. The spirit of the letter was in obvious contrast with the immediate action of the convention. The motion for adjournment was again voted down decidedly.' To the surprise of all, except the initiated, the temporary chairman. Sanford E. Church, declared the convention adjourned until the next morning at ten o'clock. Great confusion resulted. Several delegates were on their feet at once to protest the ruling. which Mr. Church attempted to explain. Cries were raised from all sides for the chairman to put the motion again. He replied that he had declared the convention adjourned; therefore, no further business could be done. By the time the noise had subsicied sufficiently for him to speak further, Felix McClosky came from one of the committee rooms. Calling to Church, he gave him a wink. Church at once took his hat and left the platform. ${ }^{2}$ The pretense given for the adjournment was that neither the committee on resolutions nor on permanent organization was ready to report. As a matter of fact, the latter committee was ready and was only waiting for its chairman to come into the hall. ${ }^{3}$

\footnotetext{
'New York Herald, Sept. I3, I866. Ibid., Sept. I2, 1866. New York Times, Sept. 12, 1866.

${ }^{2}$ New York Tribune, Sept. 12, 1866.

${ }^{3}$ New York Times, Sept. I2, 1866.
} 
The consternation was intense. Nearly all the delegates rose to their feet, calling first on this one, then on that one to take the chair. The outsiders and roughs broke in on the floor of the hall and commenced damning Church. Benches were overturned. Bedlam reigned. Surrogate Tucker gathered the Tweed crowd and proposed three cheers for John Hoffman, which were noisily given. Then followed cheers for Murphy. But when a Dix man proposed three cheers for General Dix, he was hissed and groaned down. This made clear the motion for adjournment. Senator Shafer, of Albany, a member of the committee on resolutions, mounted the platform, and with the aid of John G. Saxe, as chairman, tried to organize the body into a Democratic mass meeting, but without success. "D-n the mass meeting, we want the nomination" was the sentiment which came from the floor. ${ }^{\text {. }}$

It was thought by the Tammany supporters that on adjournment a large number of the country delegates would tire out and depart. It effected just the opposite result. However, the Dix supporters had been alarmed at the hisses which, while not in great numbers, engendered a feeling in the delegates that it would endanger the harmony of the convention if his name were pressed. Whether justly or not, the hisses were chiefly charged to Murphy supporters. Some of the western Democrats withdrew their support from Dix, thereby rendering his election improbable. Other Dix men suggested his withdrawal and concentration on either Hoffman or Slocum. The latter was persona non grata to the followers

\footnotetext{
'New York Tribune, Sept. 12, I866. That Shafer knew the crowd with which he was dealing is illustrated, when in the course of his remarks he said: "If you have not got enough money to pay your hotel bills and your fare back home, we will raise it for you": he was greeted with "Bully for you," "That's the point," "We want some place to sleep and something to eat."
} 
of Thurlow Weed, who demurred to Slocum on the ground that they had said many unpleasant things concerning him in the previous election, and did not want to swallow their own words so soon. ${ }^{{ }^{2}}$ It was generally understood that each should vote as he saw fit upon the first ballot; then, if it was seen that Dix had no chance, to go for Hoffman in a body.

In the early part of the convention Thurlow Weed, backed by Henry Raymond and the Times, made great efforts in aid of General Dix. Weed perceived, however, after the fourth adjournment that he was vanquished. Horace Greeley describes his discomfiture with a pleasant relish.

He became careless, ate two suppers, and spent most of the night smoking his mean cigars and prophesying the defeat of the party this fall. He couldn't be consoled, and the Hoffman men did not try to console him. They maintained that the Convention was a Democratic one and Weed should be satisfied with a back seat. ${ }^{2}$

The Convention re-convened the next morning, September r2, I866. Mr. A. H. Green, chairman of the committee on permanent organization, reported Hon. Sandford E. Church for president. Francis Kernan moved the adoption of the committee's report in a conciliatory speech.

He knew that there were a few members who felt aggrieved by the decision of the Chair yesterday. He regretted this very much, but still not more, nor as much, as our eminent presid-

' New York Herald, Sept. 12, I866.

'New York Tribune, Sept. 12, I866. A Tammany delegate was reported to have made the following remark, which Greeley, in a very compassionate spirit, felt the necessity to report: "Thurlow Weed is an old, played-out stump, and he cannot shove any old-time granny like Dix on the Democratic party! No! not if the Court knows itself, which she thinks she does." 
ing officer. After his very proper and handsome explanation this morning he felt certain there was not a delegate present who would not freely and fully credit the circumstance to inadvertence and not to intention. ${ }^{1}$

When Mr. Church resumed the chair he was greeted with great applause intermingled with hisses. He closed the incident of the previous day in a few well chosen words calculated to carry belief.

Shortly after the convention had been called to order, Judge Pierrepont, in seconding the nomination of John T. Hoffman made by A. Oakey Hall, coolly announced that he was authorized by General Dix to withdraw his name. ${ }^{2}$ Pierrepont's effrontery was still more pronounced when he stated in the same speech, that he had united with the Hoffman Democrats before the Philadelphia convention. Judge Pierrepont had ostentatiously refused to participate in the Philadelphia convention and in his speech at Albany, for the first time, virtually assigned the reason for so doing. He said that, "Three months ago several of us assembled together in the City of New York and decided that Mayor Hoffman should be nominated for Governor." ${ }_{3}$ It is evident that

'New York Times, Sept. I3, 1866.

${ }^{2}$ New York World, Sept. I3, I866. "He said that he desired to make a few words of explanation in reference to what had occurred yesterday partly on account of a misapprehension on the part of the Chair, and partly on account of a misapprehension by a portion of the Convention. When the Chair found that neither of the Committees were prepared with a report, he supposed that the Convention would be inclined to yield to an adjournment until this morning. When the motion was made to adjourn the Chairman declared it carried, hastily, perhaps, before the voting was finished. If that created any ill feeling in the mind of any gentleman present, no one more regretted it than the Chair.'"

${ }^{3}$ New York Times, Sept. 13, I866. Pierrepont closed his speech thus: "My friend, my intimate friend, one whom I respect, whom I personally like, has had his name before this Convention, and with or 
Pierrepont played the traitor to Dix, for Weed declared that on the day previous Judge Pierrepont had concurred with him that Dix was the logical candidate. ${ }^{ }$

Mayor Hoffman was enthusiastically nominated by acclamation and was immediately notified of his nomination, so that he was enabled to reach the convention at one-thirty in the afternoon, and make an address of acceptance. He spoke in a self-laudatory manner of his conduct in former offices. ${ }^{2}$ He decried the Radicals and emphasized the importance of looking out for the constructive rights of New York State and the Democratic party. ${ }^{3}$

Two names were placed in nomination for lieutenantgovernor; those of Robert H. Pruyn, ${ }^{4}$ of Albany, and

without his consent, his friends who have been in recent communication with him-that gallant, excellent, noble, perfect gentleman, and statesman-have desired me to say when I got up here to speak that the name of General Dix should be no longer before this Convention, but should be withdrawn in favor of John T. Hoffman." New York Tribune, Sept. 13, 1866.

${ }^{1}$ New York Times, Sept. 17, 1866.

${ }^{2}$ His infamy and connection with Tweed were not then generally known. The Times had this to say on Hofiman: "He is a gentleman of ability and eminent purity of character and his course during the war was patriotic and unexceptionable. We do not think that he will command as large a degree of public confidence and support in the pending canvass as would General Dix. . . However, . . . Mr. Hoffman is a gentleman to whom no possible exception can be taken on personal grounds." New York Times, Sept. I3, 1866.

The Independent saw a striking similarity between Hoffman and Horatio Seymour. "Both John T. Hoffman and Horatio Seymour are aristocratic in sympathy and tastes, while 'democrats' in name; both have a clear pro-slavery record; both look for an election at the hands of the rum-selling interest, which they have served; both can boast a large following of 'friends' in the lowest strata of metropolitan ignorance and degradation." The Independent, Sept. 27, 1866.

${ }^{3} \mathrm{New}$ York World, Sept. 13, 1866.

'History of the Bench and Bar of New York, vol. i, p. 445. Robert $\mathrm{H}$. Pruyn was formerly a Whig, then a strong Republican. At this time he zealously advocated a policy of prompt restoration of the Union 
Harlow L. Comstock, of Wyoming. On the defeat of General Dix, the western delegates made a strong effort to force the nomination of $\mathrm{Mr}$. Comstock. It was argued that this recognition should be given to the Dix interests as compensation for his defeat.' An effort was made to have Pruyn withdraw, but the Tammany slate proved too strong, and the vote resulted in his nomination.

For canal commissioner there was no contest. William W. Wright was nominated by acclamation. For inspector of state prisons, Mr. Washington J. Smith withdrew from the field in favor of Frank B. Gallagher, of Buffalo. ${ }^{2}$

The Democratic organs outside of New York City gave very subdued accounts of the Tammany coup d'etat

by the admission of loyal representatives to their seats in Congress. He was a man of ability, great practical energy, and had had a large share of political experience. The Times regretted "exceedingly that Mr. Pruyn saw fit to accept a nomination at the hands of the Albany Convention. He regards it . not as a Democratic Convention but as a Convention of National Union Men." New York Times. Oct. 5, 1866.

1 New York Herald, Sept. 13, 1866.

'The following were announced as the new State Committee:

Ist District-Chas. G. Cornell, Peter B. Sweeney, Thos. E. Stewart. 2nd District-William M. Parks, Elias Beach.

3rd District-Peter Cagger, F. D. Laflin, Gideon Reynolds.

$4^{\text {th }}$ District-Wm. J. Averill, A. B. Waldo, George Briggs.

5th District-Delos Dewolf, Lewis H. Brown, Henry H. Fish.

6th District-Henry D. Banto, Jr., C. H. Wairath, D. L. Follett. 7th District-C. C. B. Walker, Elmore P. Rose, 'David H. Asell. 8th District-Henry A. Richmond, J. W. Sherman, A. P. Lanning. Members of the Staie Committee-at-Large were Samuel J. Tilden, N. Y. C.; Francis Kernan, Oneida; William G. Fargo, Erie.

The ticket was as follows:

Governor-John T. Hoffman, New York.

Lieutenant-Governor-Robert H. Pruyn, Albany.

Canal Commissioner-William W. Wright, Ontario.

Prison Inspector-Frank B. Gallagher, Erie.

-New Ycrk World, Sept. 13, I866. 
in the convention. Uniformly, in place of the customary blare of trumpets, those papers attempted to keep from the reading public the details of the methods used. The Utica Daily Observer was the chief Democratic sheet to suggest the turbulence in the convention, which it did in a delicate manner. "An agreement so hearty after a canvass so animated, has rarely been reached in any deliberative body." "The Ogdensburg Daily Journal was most unkind in its remarks to the discomfited Conservatives who had joined the Democrats at Albany.

They were green enough to suppose that because the Copperheads took back seats at Saratoga and Philadelphia, while Doolittle, Randall, Raymond, Weed and Co., reconstructed the Democratic party, they were to have full direction of affairs ... . but they failed to read Nasby, and learn that the first and only instinct of the Democracy is office; that however quiet they may be at meetings where no offices are to be bestowed, in nominating Conventions they are as rancorous as wolves. ${ }^{2}$

The Syracuse Daily Journal rejoiced that the Albany Regency had completely passed over to the Democrats, taking with it Mr. Pruyn.3 In the same vein Roberts, of the Utica Moming Herald, rejoiced: Le roi est mort: vive le roi. "The head of the Regency has passed away, still the Regency lives and rules." 4 Put in more sober tongue he continued that while the ticket was not one that could impel men to special activity, yet it was not one to be despised and called for organization. ${ }^{5}$ Tammany was first supported in its questionable convention methods outside of New York City by Mr. W. W. Green,

' Utica Daily Observer, Sept. I 3, I866.

'Ogdensburg Daily Journal, Sept. I4, I866.

${ }^{3}$ Syracuse Daily Journal, Sept. I2, I866.

•Utica Morning Herald, Sept. I3, I866.

${ }^{5}$ Ibid. 
editor of the Syracuse Daily Courier and Union. In a dispassionate editorial he expressed the belief that although part of the State delegates were for Dix, his attitude towards Seymour would have detracted more Democratic votes from him than he would have drawn from the Conservatives, it being admitted that he would have drawn more Conservative votes than any other candidate.

The platform reaffirmed the principles set forth by the Philadelphia Convention of August 14, I866, and promised to reaffirm and hold inviolable the faith of the Nation to the South. It urged the restoration of the great mass of people in the South to all the rights and functions of citizenship. Further, the platform affirned that "the centralization of power in this State, not less than in the Union, is fatal to the harmony of our political system. ... Recent legislation at Albany has usurped a supreme yet fitful control of the local affairs which counties and municipalities are entitled to regulate." " Lastly, the platform criticised the Radical legislative extravagance and "frauduient tampering with the public works of the State. At Washington millions have been squandered upon central schemes of local benefactions, and a partisan Congress, while reducing the appropriations for a patriotic soldiery, has not scrupled to enhance its own emoltiments of office." ${ }_{3}$ The reference to the "recent legislation at Albany" resulted from acts of the legislature, which was controlled by Radicais, placing the control of New York City administration largely under boards and commissions. ${ }^{4}$ Tammany strongly opposed the interference with their freedom of home rule.

'Syracuse Daily Courier and Union, Sept. 13, 1866.

${ }^{2}$ New York World, Sept. 13, I866.

${ }^{3}$ Ibid.

"The most important of these acts were: "An Act to create a Metropolitan Sanitary District and Board of Health therein for the preservation of life and health and to prevent the spread of disease." Lazes of 
Exactly what was the real editorial opinion of the State Democratic papers in reference to the Albany platform is difficult to gauge. From the dearth of convincing statements it would appear that the Democratic press believed it wiser to pass over the troublesome questions peculiar to New York, and direct the public eye to the principles of the Philadelphia convention alone. As was natural, the Conservatives resented the apparent intention of the Democrats to strengthen their party at the expense of the Conservatives, who har entered into the movement to organize a party founded on the President's policy with bona fide intentions. Several papers reminded the Democrats of their obligations to keep faith. "It seems clear from this statement," "remarked the Times.

that Mr. Hoffman was nominated, not as the result of any tacit or other understanding at the I'hiladelphia Convention,

New York, I866. C. 74, vol. i. p. I 14. Passed February 26, 1866. This act was amended April 19, 1866, when special directions as to enforcement and penalties were given. Law's of New York, I866, C. 686, vol. ii, p. 1462 .

"An act to amend an act passed April twenty-five, one thousand eight hundred and sixty-four, entitled 'An act to amend an act entitled, "An act to establish a Metropolitan Police District, and to provide for the government thereof," passed April fifteen, one thousand eight hundred and fifty-seven,' passed April ten, one thousand eight hundred and sixty." Lazes of Nez' York, 1866, C. 84, vol. i, p. I53. Passed Feb. 28, I 866.

Metropolitan Fire Department, two acts relating to. Laws of New York, I866, C. 3I5, vol. i, p. 719; zbid., C. 756, vol. ii, p. I637.

"An Act in relation to Quarantine in the port of New York and providing for the construction of the permanent Quarantine establishment." Laws of New York, 1866, C. 751, vol. ii, p. 1625.

The Registry Law, also, was amended. "An Act to ascertain by proper proofs who shall be entitled to the rights of suffrage." This was a stringent tightening up of the Registry Laws, which placed the metropolitan police largely in control. Laws of New York, I866, C. 812, vol. ii, p. r780.

${ }^{1}$ Pierrepont's Speech before the Convention. Cf. supra, p. ro6. 
but as the result of a meeting of 'several of us' held in New York two months before the Philadelphia Convention assembled; and not as the exponent of its principles, nor for the purpose of carrying into effect its purposes and objects, but as the representative of the Democratic party and for the purpose of promoting its welfare and securing its success. ?

The Conservatives were further disgruntled over the insertion into the Albany platform of a plank which condemned the several boards and commissions provided for New York City by the Radical legislature. ${ }^{2}$ Raymond on October 2, I866, came out openly in support of the Republican ticket. The Times of that date says:

The Philadelphia Convention had indicated a strong desire, on the part of patriotic men in both sections, for a restoration of the Union upon just and Constitutional principles; and there was a large body of people ready to waive their party relations for this specific purpose, and co-operate in measures to give this desired effect. The Democrats believed that they could use this disposition for their own party purposes. They seized upon it, not to co-operate in carrying it out, but to make it do their party work. ${ }^{3}$

"We are opposed, out and out, to the election of the Democratic State ticket nominated at Albany, and in favor of Fenton, Woodford, and their associates, on the the Union State ticket," said the Times of October 5, I866, in answer to a quibble issued by Thurlow Weed in the Albany Evcning Journal. ${ }^{4}$

Thurlow Weed, in a letter to the editor of the New York Times, stated what he understood to be the pur-

${ }^{1}$ New York Times, Sept. 17, I866.

${ }^{2}$ The Police Commission, the Board of Charities, the Emigration Commission, the Central Park Commission and the Board of Health, all came in for condemnation.

${ }^{3}$ New York Times, Oct. 2, 1866.

- Albany Evening Journal, Oct. I, 1866. 
port of the Albany convention. The two reasons he gave for the preservation of the Philadelphia principle in the convention at Albany were: "First, that the Democratic Party were in a pronounced minority; and second, that its odor of disloyalty restrained Republicans, however opposed to Radicalism, from uniting with it as a Party." Weed regretted the action of Judge Pierrepont.

That the Democratic Party consented, for the acconplishment of a great national reform, to temporarily merge itself in the National Union Movement, was my understanding and expectation. That, too, was the understanding of the late Mr. Richmond, with whom I held frequent, frank and unreserved conversations. I advised the Philadelphia Convention .... that if the Democracy would, by its experience in adversity, learn that it could only restore itself to popular confidence by becoming loyal, a reform Democracy would ultimately recover possession of the Government. And I now avow, umhesitatingly, my conviction, that the Government would be safer in the hands of such Democratic statesmen, as Marcy, Wright and Dix, than with the reckless red radicalism which rules the present Congress .... . For myself there is nothing political in the past that I would recall. All that I uttered, before and during the rebellion, may be read with approval now, . . . I I differ with Judge Pierrepont and the World in my understanding of the character of the State ticket for which I shall vote. ${ }^{1}$

James Gordon Bennett experienced a change of heart. He had been a firm supporter of the Johnsonian policy, but, Jolnson's conduct and the Maine election evidently foretold him of danger.

We are convinced from the significant results of the Maine election that this anendment will carry all the Northern States yet to come.... We would therefore urge upon President Johnson the statesmanlike policy of a truce with Congress, and

${ }^{1}$ New York Times, Oct. a. 1806. 
an active co-operation with the fixed and predominant public opinion of the North.'

Bennett's desertion of President Johnson and the Democratic party was a grievous blow to the Democrats. The World impotently remarked concerning the change in the Herald's attitude, "Its opposition is harmless but its coöperation is disgusting. . . No man can foretell what its crass stupidity and blind selfishness may inflict upon the Tribune, [and] The Independent, . . . . Wendell Phillips hardly deserved this-Thaddeus Stevens was worthy of a milder fate.",

The World of October 5, 1866, maintained that "The New York delegation to Philadelphia was appointed by a gathering of politicians at Saratoga, which neither represented, had any authority to bind nor made any pretense of binding the Democratic organization of the State." The World then asked :

Did the Democratic Party then and there, acting through its accredited representatives, agree to give up its organization, abandon its name, and merge its existence into a new party? So far from it, that then and there, in spite of urgent, persistent entreaties to the contrary, it determined to issue its regular and customary call for a Democratic State Convention.

The Albany Argus took the same attitude as the World. $\mathrm{Mr}$. Weed denounced the spirit of the two papers and claimed that the majority of the leading Democrats of the State were acting in good faith.

'New York Herald, Sept. 15, I866.

${ }^{2}$ New York World, Sept. 20, i866.

Note. - The colored people of the State gathered in convention at Albany on October I6. I866, through a call issued by the Colored People's State central committee. The convention, which lasted two days, was attended by what Horace Greeley termed a "fine body of men." (a) A platform was adopted, the chief provisions of which maintained, that 
the $\$ 250$ property clause for colored people in the State constitution was unjust, and "that the elective franchise in this Republic is not a gift but a right belonging to all native-born men." (b) A joint address was issued to the Democrats and Conservatives which made a statement of what the negroes believed to be their duty, and, also, begged for recognition. (c) The Tribune, by its conciliatory attitude towards the negroes, drew the few votes of those qualified. (a) New York Tribune, Sept. I7, 1866. (b) New York Herald, Oct. I8, I866. (c) Ibid. 


\section{CHAPTER V}

\section{The Campaign of 1866}

The State campaign of 1866 was waged with an ardor and a seriousness akin to a Presidential election. The Iudependent, a paper which represented the moral and religious sentiments of the community, voiced the Radical battle-cry, "All hail to a reconstructed Union on the granite of Impartial Suffrage." policy occupied the forefront among the issues. However, there was one local question which caused the Democrats, in attempting to avoid it, considerable anxiety: namely, the question of legislative commissions for New York City. It was well known that Hoffman, as mayor of the City, was mortally opposed to the legislative action which took control of municipal boards from the mayor and the common council. The Times publicly accused Hoffman of being pledged to do away with these commissioners and to "leave the city to itself." " It called to mind the administration of the City under the old system, and asked what might have happened during the summer of I866, with Mayor Hoffman's Democratic board devising means to keep off the cholera.

Horace Greeley questioned the citizens of New York City if they desired a return "to the Health Boards of the Ring, under which from 7,000 to I0,000 preventable deaths occurred annually." or if they desired a return to

'The Independent, Sept. 20, 1866.

${ }^{2}$ New York Times, Oct. 9, 1866. II5] 
the old Volunteer Fire Department system "with all its rowdyism, violence, rioting, bunking, false voting, and all its immoralities and costliness." "Remember, then," said Greeley, "that a vote for Mr. Hoffman consigns the City to the mercy of the Rings."' James Gordon Bennett charged that Hoffman owed his nomination as mayor of New York City and as Governor of the State to the corrupt patronage of "Street Commissioner Charles G. Cornell and his deputy, Supervisor Tweed." Harper's Weekly believed that aside from all other objections to Hoffman, the fact that he was " the candidate of the 'Ring,' which has made the name of New York City government a stench in the national nostrils," would be fatal to his candidacy. ${ }^{3}$

The World, forced to an answer by the constant "bugabooing" ${ }_{4}$ of the Republican organs, gave the lie direct. "They sustain their calumny with not an atom of evidence or fact. They advance it as a naked falsehood, without color of excuse or pretense of proof."' 5 The Tribune made another troublesome charge which the Democrats, in general, and the World, in particular, saw fit to ignore. Hoffman's Copperhead affiliations were reviewed and he was burdened with this utterance made in the Presidential campaign of 1864 : "If Tennessee is not allowed to vote in the Electoral College, and Lincoln should be elected, I would advise revolution and resist-

${ }^{1}$ New York Tritune, Oct. 13, I866.

${ }^{2}$ New York Herald, Oct. 13, 1866.

${ }^{3}$ Harper's Weekly, Oct. 20, 1866, p. 658.

"New York World, Oct. 19, 1866. The "Herald, Tribune and Times, are now bugabooing in vociferous concert that the election of $\mathrm{Mr}$. Hoffman would be a deliberate surrender of this city into the hands of the plunderers of the Ring."

${ }^{5}$ New York World, Oct. 19. 1866. 
ance to the Government, and you may know which side to find me on."

Where campaigns were in progress, the President, also, did much to hurt the National Union cause, ${ }^{2}$ through his great use of the "spoils system." "The President is making vigorous use of the opportunity afforded him by the recess of the Senate to sweep the public service clean of all persons who do not approve of his 'policy,' and put in their places those who do." 3 Thurlow Weed

${ }^{1}$ New York Tribune, Oct. 5, 1866.

${ }^{2}$ A small, witty, campaign book, which had great popularity and was a potent factor in the opposition to Johnson, was entitled: "Swingin Round the Cirkle," by Petroleum V. Nasby (D. R. Locke). [Illustrated by Thomas Nast.]

" Late Pastor of the Church of the New dispensation,

Chaplain to his Excellency the President and P.M. at the Conferate $x$ Roads, Kentucky."

The satire of the dedication gives the key note to the whole volume.

"Dedikashun uv this book

To

Androo Johnson

The Pride and Hope uv Dimocrisy

Who hez bin Alderman uv his native village.

Guvner uv his State,

Member uv the lower house uv Congress,

And likewise uv the Senit,

Vice President and President, and might hev bin Diktater,

But who is nevertheless, a Humble Individoaal;

Who hez swung around the entire cirkle uv offishl honor, without feelin his Oats much:

The first public man who considered my services worth payin for:

This volume

Is Respectfully Dedikated."

David R. Locke, of the Toledo Blade, first published the series in his paper.

${ }^{3}$ The Nation, Sept. 6, 1866, p. I91. Ibid., Sept. 27, 1866, p. 24 I. Johnson removed 1283 postmasters during the campaign, and a relative number of custom-house employees and internal revenue officers, Dewitt, The Impeachment and Trial of Andrew Jolnson (New York, 1903), p. 123. Referring to the office-holders Johnson in his St. Louis 
complained that "prominent among the causes of enbarrassment is the appointment of 'Copperheads' to office. Those who mislead the Administration in this respect do much wrong and more mischief. ... Wherever Copperheads are appointed to or nominated for office, the effect will prove disastrous." ${ }$

Politicians on both sides during the course of the campaign endeavored to argue philologically as to the technical use of the word happen, which is found in the constitutional clause giving the President power "to fill vacancies that may happen during the recess of the Senate." " Those who argued for Congress claimed the inference was that he had no power to fill vacancies which he himself had created, in as much as the word happen contains the idea of chance and excludes the idea of premeditation. Johnson's supporters maintained that the word happen meant occur, with the idea that any occurrence of a vacancy from whatsoever cause gave the President power to fill that vacancy. ${ }^{3}$ The Nation aptly summarized the discussion on this point: "Philological discussions, carried on half in slang and half in billingsgate by red-hot political partisans, are generally amusing rather than profitable, and the discussions we have had about the meaning of this word furnish no exception to the rule." 4

speech said: "I will kick them out just as fast as I can." The Sherman Letters (New York, I894), p. 278.- "But worse than all, his turning out good men-sometimes wounded soldiers-merely because they adhered to their party convictions, and putting in men who opposed the war throughout, is simply an unmitigated outrage that will stain the name of any man connected with such conduct."

${ }^{1}$ New York Times, Oct. 9, 1866.

${ }^{2}$ United States Constitution, Art. II, Sec. 2.

${ }^{3}$ New York World, Aug. 21, 1866.

4The Nation, Sept. 6, I866, p. I9I. 
Due to his partisan zeal and national preëminence as a clergyman, Henry Ward Beecher received much attention on account of a letter ${ }^{2}$ he wrote in answer to an invitation to attend the Soldiers' and Sailors' Convention at Cleveland. Beecher's letter had a great influence in the campaign as the best résumé of the Presidential policy yet given. $^{2}$ Beecher advocated the admission of representatives from the Southern States. "It is said that if admitted to Congress, the Southern Senators and Representatives will coalesce with Northern Democrats and rule the country." He asked, "Is this nation, then, to remain dismembered to serve the ends of parties? Have we learned no wisdom by the history of the last ten years, in which just this course of sacrificing the nation to the exigencies of parties plunged us into rebellion and war?" 3 Beecher believed that the new and more advanced ideas resulting from the experience of the previous five years were sufficient to avert the dangers which were feared from a participation of the South in the government. ${ }^{4}$

'The Independent, Sept. 6, I86t.

'Harper's Weekly, Sept. 22, I866, p. 594. Harper's Weekly demurred to the letter. . "We must say frankly that, as a campainn document, it will persuade only those who do not understand the question. For it does not seem to us to touch the question. To be asked whether it is convincing is likc being asked aiter a feast of watermelon, how the peaches taste. We have not tasted them."

${ }^{3}$ The Independent, Sept. 6, I866.

'Ibid. The following passage in Beecher's letter is suggestive of his prescience in the treatment of the negro problem: "Civilization is a growth. None can escape that forty years in the wilderness who travel from the Egypt of ignorance to the promised land of civilization. The freedmen must take their march. I have full faith in the results. If they have the stamina to undergo the hardships which every uncivilized people has undergone in their upward progress, they will in due time take their place among us. That place cannot be bought, nor bequeathed, nor gained by sleight of hand. It will come to sobriety, virtue, industry and frugality. As the nation cannot be sound until the South is prosperous, so, on the other extreme, a healthy condition of civil society in the South is indispensable to the welfare of the freedmen." 
Horace Greeley took up the cudgels against Beecher. "The Rev. Henry Ward Beecher has written a letter approving the Cleveland Convention, which shows that the war has taught him nothing, while he has forgotten his own teachings." The Times remarked:

What a pity it is that Mr. Beecher is so stupid! If he had been so docile and quick to learn as the Tribune, he might have been possibly as wise now as that journal was when it advocated the right of secession, urged peace 'on the best obtainable terms ' if one more battle should fail, and proposed to pay the Slave States, rebel and loyal alike, $\$ 400,000,000$, as compensation for the loss of their slaves. It is a great misfortune that $\mathrm{Mr}$. Beecher is so dull. ${ }^{2}$

However, slightly over a month later, we find Beecher making the ratification speech, at the Brooklyn Academy of Music, for Fenton and the Radicals. "The continuance in power of the Republican Party is indispensable to the great work of raising up the Freedmen to security and

'New York Tribune, Sept. I, I866.

${ }^{2}$ New York Times, Sept. 3, i866; New York World, Sept. 1o, i 866. The World, also, came out in strong support of Beecher on the occasion of his second letter. "Mr. Beecher remains a Republican: remains a devoted friend of the black race; remains a vigorous advocate of the right of the negroes to the ballot."

The Nation, Sept.6, I866, p. 192. The Nation praised the letter "as perhaps the most taking and specious statement yet made of the Johnson position," but added, "the fault of the letter is not that its statements are not true, or that its arguments are fallacious, but that nearly every line of it suggests false inferences, and this it is, added to the character of the author, which makes it likely that it will do a good deal of mischief." . When Mr. Beecher calls on us 'to dismiss from our minds the idea that the freedmen can be classified and separated from the white population and nursed and defended by themselves,' he is guilty of something very like a sophism. One great cause of the present trouble is that the South insists, in spite of the warning of history, in classifying the freedmen. 'and bases its classification on the absurd distinction of color." 
intelligence and citizenship," was the sentiment of his

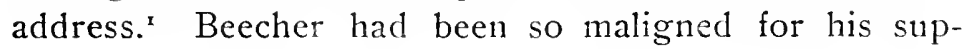
port of Johnson's policy, that at last, completely disgusted with the President's erratic course, he left him to his fate. "Mr. Johnson just now and for some time past has been the greatest obstacle in the way of his own views. ${ }^{2}$

The Fenian agitation, with which the papers of this period were filled, exerted a strong influence upon the campaign due to the large Irish population in New York State, its proximity to Canada, and the pro-Irish sympathy which was prevalent. ${ }^{3}$ The Radical leaders endeavored, with the aid of the New York Tribunc ${ }^{4}$ and the Radical up-State papers, to influence the Fenian vote in favor of their policy. President Johnson took

'New York Tribune, Oct. 16, 1866.

${ }^{2}$ Quoted from a private letter, Sept. 6, 1866. Alexander, 4 Political History of the State of Nert York, vol. iii, p. I63.

${ }^{3}$ The Fenian movement, remotely, was the outgrowth of Irish hatred for England, immediately, it developed from the "Young Ireland" movement of $1848-9$. The Fenian movement received its name from a secret brotherhood, which had lodges in most of the important cities of Europe, Great Britain, Canada and the United States. The secrecy with which the order was guided, together with its great chain of lodges, made the movement most formidable. Various invasions against and uprisings in Canada were planned and attempted. These movements largely had their base in the United States, and correspond to similar movements in and against Ireland. Eventually, the active measures taken by England to suppress the movement effected its overthrow.

${ }^{4} C f$. speeches of Schuyler Colfax and General John A. Logan. New York Tribune, Aug. 16, I866: Aug. 18, 22, I866. Also Binghamton Daily Republican, Aug. 30, 1866; Sept. II; Oct. 31, 1866; Syracuse Daily Standard, Oct. 30, I866; Buffalo Express, Oct. 10, Nov.6, 1866. Buffalo was one of the Fenian centers. The Express worked hard to secure the Fenian vote for the Radicals. The Buffalo Daily Courier, Oct. I0, 31, I866, tried to off set the Radical organs by telling the Fenians that all the Radicals wanted was their votes and then the Fenian movement would be deserted. This proved true. 
firm and active measures to stop the preparation of Fenian raids within the United States. $\mathrm{He}$ also did all in his power to have the neutrality laws observed. The President's strict adherence to duty in relation to the Fenians cost him and the Democrats a large proportion of the Irish vote.' This phase of the campaign assumed considerable importance. The World commented that,

the desperate, unnatural and venal, but fortunately very transparent efforts which the Radical leaders and press have recently been making to cajole our Irish fellow-citizens over to their infernal plot for the dismemberment of our country . . . . is happily arousing the vigilance and contempt of the whole Irish race among us."

The Universe, of Philadelphia, a prominent Irish organ, reminded its readers that "these Radical negro worshippers, now biarneying them so prettily to get their votes in the coming election, are only the same herd of dark-lantern Know-Nothings, anti-Catholics, anti-Irish, pro-negro, pro-church-and-convent-burning people whom they have such bitter cause to remember." 3 Nevertheless, in the interior of the State, wherever the Irish population was numerous, and where the Democrats had

'The Nation, Sept. 20, I866, p. 221. The Nation predicted that the Conservative Republicans and Democrats would, "probably, generally lose the Irish vote in the State, owing to Mr. Johnson's dealings with the Fenians, which, however, reflected infinite credit on him and we are sorry to say his opponents, so far from praising him for this vindication of the law at the expense of his popularity, are using it against him all over the country and cajoling the Fenians with promises of impunity in their raid, which reflect about equal discredit on the American name whether they are intended to be kept or not."

${ }^{2}$ New York World, Aug. 24, 1866.

${ }^{3}$ The Universe, Philadelphia. Quoted in the New York World, Aug. 24, 1866. 
not been able to meet the Radical arguments, the Democratic vote fell off, with a proportionate increase in the Radicals' strength.' The promise with which the Radicals tempted the Irish vote in the campaign was the passage of more favorable neutrality laws.

Another important element that entered into the campaign and one which made Fenton's victory more notable, was the excise movement. A stringent excise law was passed on April I4, 1866, ${ }^{2}$ which caused great excitement in the metropolitan police district. The law was rigidly enforced through the months of May and June, I866, but after the Fourth of July the authorities gave up its enforcement, in consequence of a decision by Judge Cardozo declaring it unconstitutional. ${ }^{3}$ On Sunday, July ist, two hundred and eighty injunctions were served permitting open saloons. ${ }^{4}$ Governor Fenton, in order to settle the troublesome question at once, called a special term of the Supreme Court for the first judicial district. ${ }^{5}$

A case was brought up under this law in which the lower courts decided that the law was constitutional. The case was taken up to the Court of Appeals, where the lower court was sustained, in the Metropolitan Board

'New York World, Nov. 7, 1866.

${ }^{2}$ Laws of New York, 1856, C. 578 , vol. ii, p. 1242. "An Act to regulate the sale of intoxicating liquors within the Metropolitan Police District of the State of New York." No one could cispose of spirituous liquors in quantities less than five gallons at a time without a license. Only persons of good moral character were permitted to receive licenses. No liquor could be sold to persons under eighteen years of age. All places where liquors were sold, except regular hotels subject to restriction contained in the act, were required to close between midnight and sunrise, also on Sundays. Provisions were made for enforcement, prosecution and penalties.

${ }^{3}$ Harper's Weekly, Nov. Io, I866, p. 706.

"Ibid.

${ }^{5}$ New York Herald, July 2, I 866. 
of Excise v. John Harris et al., and in several other cases." Hoffman and the "Ring" were forced to bear the full brunt of the attacks from the supporters of the excise. Harper's Weekly was uncompromising: "It is not a pleasant thing to say, but it is the strict truth, that $\mathrm{Mr}$. Hoffman is the candidate of the 'conservatism' of the grog-shops." = The Independent made it doubly hard for Mr. Hoffman and Tammany Hall to ignore its blunt attack. "Mr. Hoffman is opposed to a law which closes the rum-dens on the Sabbath; is opposed to a law which shuts up the grog-shop at midnight; and forbids it to be reopened until daylight-which forbids women to sell strong drink, or boys under eighteen to buy it." 3 The sole argument which the Democrats advanced against the attack was that the harmless customs of a large portion of the population were ignored. ${ }^{4}$

In the eastern and southern counties of New York State, especially those in which the patroon system of

'Metropolitan Board of Excise t. John Harris, et al., 34 N. Y., 657. The points upon which the courts gave decisive dicta were: That the legislature of the State had a constitutional right to regulate and control the liquor traffic; that neither the State nor the United States Constitution places a limit upon the legislature in its regulation of a traffic which is connected with public morals, safety and prosperity; that a law which prohibits an indiscriminate traffic in spirituous liquors. and places the trade under public regulation, violates no constitutional restriction; that licenses to sell liquor are mere temporary permits, giving legal protection to what would otherwise be unlawful, not contracts between the State and the licensee, giving the latter vested rights; and further, that such licenses are not property in any legal or constitutional sense.

${ }^{2}$ Harper's Weekly, Nov. 10, 1866, p. 706.

${ }^{3}$ The Independent, Sept. 27, 1866.

'Of the up-State papers, the Binghamton Daily Republican, Oct. I0, 21, 24, I866. led in the attack upon the liquor interests of New York City. 
former days had flourished, a revival of the anti-rent ${ }^{x}$ agitation exerted a strong influence upon the campaign of 1866 . The anti-rent troubles came to a head in the town of Knox, Albany County, and spread along either side of the Hudson, wherever lands were still held under the old "lease-hold" system. In July, of I866, it became necessary to detail a battalion of the tenth regiment of militia to suppress the disturbances, but no fire-arms were used or actual bodily resistance given. The troops were met by a considerable body of men, who broke and ran, nine prisoners being taken. ${ }^{2}$ Similar disturbances of a more violent sort broke out in the town of Berne, resulting in an ambuscade of Colonel Walter S. Church, who was connected with the Van Rensselaer's by marriage, and had, as agent for the owners, made himself particularly obnoxious to the lease holders. ${ }^{3}$ Colonel Church was a local Democratic politician of some note. This, together with the fact that a majority of the land owners were Democrats, produced a strong reaction in that portion of the State against the Democrats. The New York Times, in commenting on the anti-rent movement, said :

This party again manifested its influence at the polls on Tuesday last. Most of the prominent owners of these lands are Democrats .... the particular agent for the collection of rents and distraints from delinquents together with the sheriff, who

'Originally started about $\mathrm{s} 839$. The movement aimed to break the onerous control of the descendants of the Dutch patroons over the "lease-hold" lands throughout the eastern and southeastern counties of the State.

2 These disturbances continued throughout the summer and broke out with renewed vigor in September. Vide Troy Whig, Sept. 28, I866; Troy Times, Sept. 26, 1866.

'Appleton's Ann. Cyc., 1866, pp. 543-4. 
is a Democrat.... divided the curses of the inhabitants. This feeling has reacted upon the party of which they are members and many votes were lost in this region to that once allconquering organization.'

The New Orleans and Memphis massacres, together with the pictures in Harpor's Weekly and the letters of Petroleum V. Nasby contributed powerful Radical arguments to the campaigtr. ${ }^{2}$

1 New York Times, Nov. 14, 1866. For a detailed discussion of the anti-rent agitation see David Murray, The Anti-Rent Episode in the State of New York, Annual Report of the Amer. Hist. Assoc., I896, vol. i, pp. 130-172; Albany Freeholder, organ of Anti-Rent party, April, I845 54; Franklin B. Hugh. Gazettecr of the State of Newe York. I873; Edward P. Cheyney, The Anti-Rent Agitation in the State of New York, 1839-46 (Phila., 1887), p. 46; Senate Documen's, 1835-1851; Assembly Documents, i840-I855; Lincoln. Messages from the Governors. vol. iv, p. 413; Lawe of New York, 1846, C. 274, vol. i, p. 369; ibid., C. 327, vol. i, p. 466; The People v. Van Rensselaer and others, 9 N. Y. 291; The People v. Clarke, 9 N. Y. 349.

${ }^{2}$ Cf. Harper's Weekly. Aug. 25, 1866 . for pictures and account of the massacres. See New York Tribune, Oct. 3, 1866, for the report of the military commission which investigated the New Orleans massacre. Thomas Nast was a powerful factor backed by Harper's Ireekly in lampooning Johnson with his pictures. One of Nast's most notable caricatures appeared September I, I866. Johnson was represented as Othello, saying to Iago, a discharged negro soldier, " Dost thou mock me?" to which Iago replied: "I mock you! No, by Heaven. Would you could bear your fortunes like a man." Surrounding Johnson are pictures of Southern rights-" What they were " $-i . e .$, negroes being sold and whipped. The contrast with their present condition was reuresented by the slaughter at the New Orleans and Memphis massacres. Under the central portion, Johnson is represented as a snake charmer, seated in oriental manner playing upon a reed, riz., the United States Constitution, while before him a C. S. A. rattlesnake and a Northern copperhead snake are strangling and biting a negro. Chase. Stanton and Seward, dressed in oriental garb, stand gravely by. Placards surround Johnson, bearing sucl sentiments as "Treason is a crime and must be made odious, and traitors must be punished," . Love thine enemies," "I am your Moses." Other virulent caricatures appeared in Harper's Weekly on September 8, 1866, September 29. 1866, p. 6r7, 
The treatment of Union soldiers in the Southern prisons was also a stimulant to fury against the Democrats. $^{{ }^{3}}$ The latter on their part were not slow to charge Congress with a betrayal of the United States Constitution in making the ratification of the Fourteenth Amendment a requirement before the admittance of the late Confederate States.

Roscoe Conkling, who was making what proved to be his last campaign for the House of Representatives, ${ }^{2}$ toured the State extensively. In his opening speech at Utica on September I3, I866, Conkling struck the keynote of the Republican campaign. He began with the statement that Reconstruction was an exaggerated question, artificially manufactured by politicians, and a mere distortion of reality. The commercial, the agricultural, the material, the social, even the political prosperity of the South, did not and does not depend at all upon

October 27, 1866, pp. 685-I, November 3, I866, p. 696; the last being "Amphitheatrum Johnsonianum," which represented Johnson as Nero, looking on composedly at the "Massacre of the Innocents," called to mind by the race riots in New Orleans and Memphis. For the complete cycle of Nast's pictures see Albert Bigelow Paine. Thomas Nast -His period and his pictures (New York, 1904), passim.

'Assembly Documents, vol. iv, pp. 358-429, give a detailed account of the conditions in Southern hospitals and prisons. The diary of one Samuel Henderson is given in full during his incarceration in Andersonville:

"June 23-Went down to the creek to wash my clothes, but the water was so muddy and greasy that I could not; this is the water we have to drink; the rebels do all their washing in it above, and throw all the slops from their work-house into it," pp. 420-1.

-July 20--There was a prisoner shot to-day by one of the rebel officers. His offense was asking for rations," p. 422 .

"Dec. 10-My weight before being taken prisoner was 142 lbs. When I arrived at Annapolis my weight was 55 lbs.." p. 429.

"Conkling, in the following January, 1867, was elected to the United States Senate from New York, where he served until his resignation in May, I88I. 
whether members of Congress from the South commence speaking and voting twelve months sooner, or twelve months later. "They should need to sow, they had need to plant, they had need to build, they had need to mend, they had need to heal . . . . in short, their need of needs was to go to work." "

The dawn of a new era was gradually beginning to diffuse itself over the politics of the State. Seward still remained in the Cabinet, but was largely shorn of influence because of his adherence to the Presidential policy. Seward's friends were either neutral or hostile to the new program. Thurlow Weed, through his support of the ticket representing the Philadelphia principle, had lost his control over the political destinies of New York. Neither Governor Fenton nor Senator Edwin D. Morgan were adapted for oratory. ${ }^{2}$ It fell to Conkling's share to pull the stroke oar. He appealed especially to the younger men and gave to the campaign an energy and enthusiasm which materially aided in the Republican success in November. ${ }^{3}$

'New York Tribune, Sept. I8, I866. Conkling spoke in fourteen different towns. Alfred Conkling, Life and Letters of Roscoe Conkling (New York, 1889), p. 279.

'New York Tribune, Oct. 24, I866. Public men from other states gave considerable aid to the Radicals. Of these, the most notable was General Carl Schurz, who bitterly arraigned the President at a large meeting in Brooklyn.

${ }^{3}$ Alfred R. Conkling, Life and Letters of Roscoe Conkling, (a), p. 273; (b), p. 278. Two extracts from Conkling's speech at Mechanics' Hall, Utica, Sept. I3, I866, may furnish some insight into his power. When commenting on the investigation of the Congressional Reconstruction Committee, he said: "It prepared us to find that nowhere in the South was the Fourth of July celebrated except by negroes. It prevented our being much surprised when women and children were shot down for strewing flowers upon soldier's graves. This happened in South Carolina, and James L. Orr says South Carolina is perfectly loyal; but then these women and children were black and the tenants of those graves, 
For the Democrats, Mayor Hoffman toured the State. Though not an orator, he had a manner which pleased, and he discussed constitutional ${ }^{\mathrm{r}}$ principles in good legal fashion. Hoffman had worked his way up through New York City politics, and as mayor of New York had made a record which suited Tammany. At the time of his nomination his record had been spoken of as clean by the Times. ${ }^{2}$ Nevertheless, Hoffman did not escape the stinging criticism of Horace Greeley who, charging him with disloyalty, strongly intimated that he had been a Copperhead. ${ }^{3}$ While no open charge of dishonesty was made against him, he was accused by the Trioune of being "the pet, the nominee, the figure-head, of the 'Ring' which so flagrantly misrules and plunders our city." 4 In confirmation of these attacks, speaking of Hoffman's administration as mayor, Gustavus Myers has written: "There is little to say of Hoffman's administration. Frauds and thefts of every description continued as before, though it is not possible to connect his name with any of them." ${ }_{4}$ The Argus constituted itself a special agent to reply to Greeley's attacks, ${ }^{5}$ but its counter charges of fraud and usurpation failed to silence the Radical press.

though white, died for the Union, and they had no epitaph except the word 'Unknown.', (a) In an endearing reference to the President, he said: "Not satisfied with conniving at the robbery and murder of the Unionists, and the exaltation and reward of traitors at the South, he comes to buffet and slander the Union people of the North and to blacken the memory of their dead." (b)

'Syracuse Daily Courier and Union, Oct. II, I3, I5, I866; Rhodes, vol. vi, p. 4or; Alexander, A Political History of the State of N'ew York (New York, I909), vol. iii, p. 164.

${ }^{2}$ New York Times, Sept. 13, I866; also cf. supra, p. 106, footnote 3.

${ }^{3}$ New York Tribune, Nov. I, I866.

' Gustavus Myers, The History of Tammany Hall, p. 249.

'Albany Argus, Oct. 5, I866; Oct. 15, I866; Oct. I6, I866. 
During the campaign in the central and western counties of the State all was far from peaceful within the Republican ranks. In Monroe County a permanent feud had arisen. Roswell Hart, the Radical Congressman from the twenty-eighth district, had been opposed for renomination by a strong opposition candidate, Lewis Selye by name. Both sides had held separate nominating conventions and both candidates had accepted. This led to a very bitter local campaign, in which charges and countercharges of bribery and fraud were common. ${ }^{2}$ Mr. Selye won the election. ${ }^{2}$ Further, family quarrels broke out in the Oswego and Cortland County Congressional districts, to which the Democratic organs pointed as an exampie of the vaunted harmony among the Republicans of the State. ${ }^{3}$ Among the State Democrats, Thurlow Weed was given a scant welcome into Democracy. He was constantly watched for evidence of a lack of faith. The Syracuse Daily Courier and Union was openly hostile to him. "Mr. Weed, in the garb of a friend, and while professing alliance with the Democratic party, is seeking its ruin. ... He still labors, as he has always labored, to distinguish and divide Democrats as loyal or disloyal during the war." ${ }_{4}$

${ }^{1}$ Buffalo Daily Courier, Sept. 6, 1866.

'Rochester Daily Democrat, Nov. 8, 1866.

${ }^{3}$ Albany Argus, Oct. 5, 1866.

* Utica Morning Herald, Sept. 21, 1866; Syracuse Daily Courier and Union, Oct. 12, 1866; Syracuse Daily Standard, Oct. I1, 1866. On the occasion of Weed's letter explaining why he did not follow the Times back into the Union party the Daily Standard had this to say: "Everything has conspired of late to make him fainthearted. The Unionists have denied him leadership, the Democrats will have none of his counsels. . The mission of political trimmers is gone in these earnest times and Weed who was never anything but a political trimmer, sighs as he sees his vocation depart. Honest statesmanship is what the country needs and Weed, who deals in political crugs has none 
Syracuse was again the center of the up-State campaign, especially for the Democrats. George F. Comstock, of Syracuse, ex-Chief Justice of the Court of Appeals, proved to be a powerful factor for the Democrats in the central portion of the State. His arguments were directed against the constitutionality of the Radical reconstruction acts.' Pruyn also supplemented Hoff man ${ }^{2}$ and Comstock in the central and western portions of the State. But the conservative influence of Pruyn was neutralized by his association with Hoffman. ${ }^{3}$ The forceful addresses of John Van Buren. which had delighted Democratic audiences of the previous campaign, were nissed. "Prince John," as his friends had called him, died on October I4, I866, while returning from Europe. where he had gone for his health. His death removed from the field one of the younger Democratic progressives and made the way easier for Seymour to achieve the Democratic nomination in 1868.4

The principal speakers up-State for the Republicans were Roscoe Conkling, Generals Barlow; Cochrane and of the essence of statesmanship on hand.

His friends are in a bad way. Andrew Johnson, whom he nominated at Baltimore, has been 'swinging round the cirkle.' . His friend Raymond has been executing the most miraculous feats of 'ground and lofty tumbling' ever exhibited and has finally made a scmersault in which he has landed far from his mentor and guide, who vainly beckons the graceful acrobat his way."

${ }^{1}$ Syracuse Daily Courier and Unicn. Oct. 17, 20, 1866.

${ }^{2} \mathrm{Hoffman}$ in all of his adóresses discarded the name Democrat and spoke of himself as a National Unionist.

${ }^{3}$ Binghamton Daily Republican, Oct. 24, 866.

4Syracuse Daily Courier and Unicn, Cct. 17, 1866. John Van Buren, second son of ex-President Martin Van Buren, was an attaché to the legation at London, while his father was Minister to England in 1831-2. John was tw $2 n t y-o n e$ at the time and had a flirtation with Queen Victoria, then a princess. It was this instance that gave him his sobriquet, "Prince John." 
Woodford. Their arguments in the main were aimed to prove that the Radical Congress was acting within its constitutional rights in advocating the Congressional plan. ${ }^{7}$ The President was made the scapegoat of every Radical Republican orator. "All that his former enemies have connseled him to do he has done, or means to do, if possible," " was the Radical wail. In connection with the constitutional arguments pro and con, the Republican journals began the agitation in favor of calling a State Constitutional Convention the following year to discuss and propose changes in keeping with the national questions. ${ }^{3}$

September elections in Maine and Vernont ${ }^{4}$ gave the Republicans large majorities. The Democrats had attempted to explain away the September Republican successes on the ground that these States were away from the beaten track, and that in Maine the popularity of General Chamberlain had materially influenced the election. ${ }^{5}$ But when the October election results were announced and it was found that Pennsylvania, Ohio, Indiana and Iowa ${ }^{6}$ had gone Republican, the Democratic explanations were not so profuse.

The remainder of the Northern States, holding elections in November, returned the same indication of public will. In New York State, ${ }^{7}$ with a total vote for

'Albany Ezening Joumal, Sept. 25-27, 1866; Oct. 15, 1866; Binghamton Daily Republican, Oct. 20, 1866; Rochester Daily Democrat, Oct. I6, 31, 1866.

${ }^{2}$ Utica Morning Herald, Oct. 27, I\&66; Syracuse Daily Journal. Oct. 10, 1866.

${ }^{3}$ Utica Morning Herald, Oct. 3, 1866.

'Tribune Almanac, 1847, pp. 49-50.

${ }^{5}$ Buffalo Daily Courier, Sept. 14, 1866.

- Tribune Almanac, 1867, pp. 58, 60, 61, 62 .

'Ibid., p. 5 I. 
Governor of 719,195, Governor Fenton received a 13,789 majority over Hoffman. General Stewart L. Woodford, for lieutenant-governor, increased his majority over Robert H. Pruyn to I5,023. The remaining two Republican candidates also increased their respective majorities. ${ }^{2}$

The State campaign and election were largely overshadowed by national questions. No matter of purely State policy was alluded to in the Syracuse platform. In the northern, central and western parts of the State. ${ }^{3}$ the proposition that eclipsed all other issues was the great national question of the constitutional amendment. The results in New York City and the returns throughout the State in opposition to the City were extraordinary. Hoffman's majority of 46,000 in the City, exceeded by 9,000 the Presidential majority of General McClellan. Over against this Democratic gain in the City, Fenton made sufficient gains upon his vote of I 864

'Included 354 scattering.

${ }^{2}$ Canal Commissioner, Republican, Stephen T. Hoyt, 15,551 majority over National Unionist (Dem.), Wm. W. Wright; State Prison Inspector, Republican, John Hammond, 16,273 majority over National Unionist (Dem.), F. B. Gallagher.

${ }^{3}$ Allowing for natural bias the Times gave an approximate prediction as to the political situation in New York City, when it said (New York Times, Nov. 6, 1866): “The vote in the City to-day will be cast without much reference to broad national issues. The opponents of the Police Commissioner; the advocates of unrestricted liquor dealing; those who would revive the old Fire Department and abolish the new; the Anti-Sabbatarians and the bulk of those who claim the privilege of instant naturalization on landing here; will do as they have generally done-press forward and record as many votes as they can for the Democratic candidates. . On the other side a great majority of the steady advocates of municipal reform who believe that our Police system works well and advantageously for all classes; who do not believe in the revival of the old Fire Department. or the old Police Department, but who do believe in the Health Commissioner and a stringent Excise Law -will record a steady, solid vote for Governor Fenton and generally for the Republican party." 
up-State, to defeat the "unterrified" in their metropolitan strongholds. ${ }^{\text {}}$

The Democratic majorities in New York City may be readily accounted for. The obnoxious legislation at Albany passed during the previous winter by a Radical Republican legislature against the liquor interests was an incentive for that element to present a solid front for Hoffman. In addition, there were such powerful combinations as the "Ring," the Custom House and the Post Office, all of which opposed the movement for a further check and balance system in municipal affairs. The Federal institutions in New York exerted a strong influence in favor of the Democrats through Johnson's use of the spoils system.

Although an unusually large crowd gathered in Printing House Square to learn the returns, election day in New York City passed off in comparative quiet. ${ }^{2}$ The local elections for New York County excited little comment. The chief offices filled were those of register, surrogate, recorder and coroner. Tammany Hall and Mozart Hall ${ }^{3}$ united in a temporary armistice in order

'New York Herald, Nov. 7, 1866.

¿New York Tribune, Nov. 9, 1866

${ }^{3}$ New York Herald, Nov. 7, 1866. Gustavus Myers, The History of Tammany Hall, passim. New York Times, Nov. 7, 1866. The fact that the Registry Law was in force at this election, had an undoubted tendency tc decrease the amount of fraud at the polls. (I) However, the papers mentioned a number of arrests for illegal voting, sufficiently suggestive to give ample ground for a belief as to the existence of great corruption in the use of the franchise. (2) From the up-State reports, moreover, it would appear that not all the fraud had been committed in New York City. The Times made the following comment Nov. 14, 1866: "From Rensselaer, Columbia, Saratoga and Albany counties the universal statement is that money flowed like water . . . Electors marched up to the polls under the convoy of some well known ward politician, who placed tickets in their hands as they reached the ballot boxes, and after depositing their votes touk out his pocketbook and paid them... 
to secure the election. As a result of the severe excise laws they were aided in their efforts by the unrest among the liquor interests, wholesale and retail, especially the German element. To defeat this coalition, Republicans united with the War Democrats to form an anti-ring county ticket. General Charles G. Halpine, a genuine War Democrat, ${ }^{x}$ was elected register. His majority over Mr. McCool, the Tammany and Mozart Hall candidate, was 19,09I. ${ }^{2}$ However, Gideon T. Tucker, for surrogate; John K. Hackett, for recorder; and Dr. Shirmer, for coroner, all Tammany and Mozart Hall candidates, were elected over their anti-ring opponents. ${ }^{3}$ The Republicans and Democrats elected respectively, General Alexander Shaler and G. M. Herman as supervisors. The overshadowing influence of the State contest no doubt detracted from the endeavor to oust the Ring candidates. All of the Democratic candidates for Congress from New York City were elected, which was a gain of three. ${ }^{4}$ The Fourth Congressional district in

before hundreds of people, without even the mock decency of retiring to one side." The Trilune after the election, uncer the caption "Liberty and Lager," attempted to prove that the German rote had not gone against the Radicals. New York Tribune, Nov. 9, 1866.

'Gen. Halpine had served throughout the Rebellicn as a War Democrat. He achieved considerable fame through his writings under the pseudonym of "Private Miles O'Reilly,"' which did much to popularize the Union cause with his countrymen by birth.

${ }^{2}$ Register, Halpine, 63,552. McCool, 44,46I. New York Tribune, Nov. 8, $\mathbf{1} 866$.

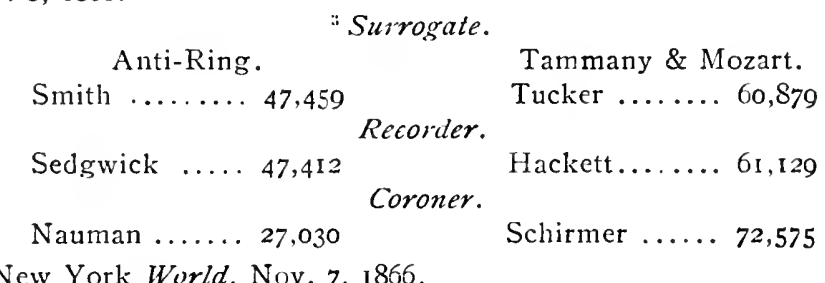

4 New York Wurld, Nov. 7, 1866. 
New York City gave Horace Greeley a sharp rebuke for his arraignment of the Ring by sending John Fox, his Democratic opponent, to Congress with a 9,988 majority. But in spite of this Greeley rejoiced, "We can beat the Ring! The defeat of Hoffman went far to insure this, but the magnificent success of General Halpine renders it a certainty." 2

The Radical majority in Congress remained in the ascendant, assuring the defeat of Johnsonian doctrines. The Congressional districts in the State maintained their Radical majority, to which was added a gain of three in New York City, of one in Brooklyn and a similar advance in the Monroe District. ${ }^{3}$ New York was represented in Congress by twenty Radicals and eleven Democrats. ${ }^{4}$

'New York Tribune, Nov. 8, 1866. Greeley, 3,607; Fox, I3,595.

'Ibid.

"Second Session, Thirty-ninth Congress.

Senate.

House of Representatives.

Radicals ...........................

Democrats and Conservatives ...... Io $\mathrm{I} 45$

-Tribune Almanac, 1867, p. 2 et seq.

${ }^{4} \mathrm{Mr}$. James Brcoks's return to Congress by the Democrats of the Eighth District, was made notable by his defeat of Mrs. Elizabeth Cady Stanton, the first woman to aspire to a seat in Congress upon a straight Woman Suffrage ticket. The New York delegation in the next Congress was:

Ist District-- Taber, Democrat.

$\begin{array}{ccl}\text { 2d } & \text {.“ } & \text { Barnes, Democrat. } \\ 3^{\text {d }} & \text {. } & \text { Robinson, Conservative. Democratic gain. } \\ 4^{\text {th }} & \text {. } & \text { Fox, Democrat. } \\ 5 \text { th } & \text {. } & \text { Morrisey, Democrat. } \\ 6 \text { th } & \text {. } & \text { Stewart, Conservative. Democratic gain. } \\ \text { 7th } & \text {. } & \text { Chandler, Democrat. } \\ \text { 8th } & \text {. } & \text { Brooks, Democrat. } \\ \text { 9th } & \text {. } & \text { Wood, Democrat. Democratic gain. } \\ \text { Ioth } & \text { Robertson, Radical. Radical gain. } \\ \text { I Ith } & \text { Van Wyck, Radical. Radical gain. }\end{array}$


The election left the New York State senate unchanged, with the exception of the twenty-seventh district, where the vacancy caused by the resignation of Canal Commissioner Hoyt was filled by John J. Wicks. This gave the senate twenty-six Republicans to six Democrats. In the assembly eighty-four Republicans were elected to forty-four Democrats, thus giving the Republicans a majority of sixty on a joint ballot. As will be shown, the election of a Republican United States Senator to succeed Senator Harris was assured.

With no escape from two years more of Republican administration the World $^{x}$ consoled the Democratic masses of the State, especially those of New York City, on the splendid fight they had made "for the true Union cause." But, while it made a plea for fair play, it could

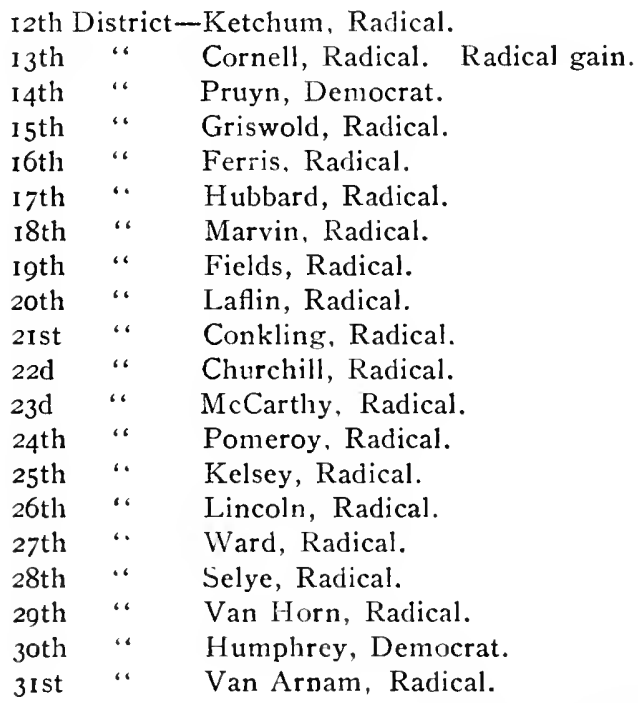

-New York Tribune, Nov. 9, 1866.

' New York World, Nov. 7, 1866.

${ }^{2}$ New York World, Nov. 8, 1866 . "By means of registry laws, ex- 
not resist the threat that "if there is to be peace between us, let the Albany legislators try an entirely different policy." James Gordon Bennett reminded the public that he had predicted the election of Governor Fenton, because of the principle for which the latter stood. "Governor Fenton is elected by a vote just large enough to express the State's endorsement of that policy, and just small enough to show that it is on that issue alone, despite his own weakness and imbecility, that he has been successful.",

The leading Republican organs were a unit against the imputation of the World that "The recent elections have been carried by the Radicals on false pretences," as "deceitful maneuvers preliminary to the Presidential election" through which they may say "whether the Southern electoral votes shall be counted." 3 The self-evident moral of the election for the Southerners, seen through Republican eyes, was to submit to the inevitable and ratify the amendment. ${ }^{4}$

The comments of the State journals were various.

cise laws and commissioners depriving us of local freedom, they hoped to swell the Radical vote, but it has had a directly opposite effect. Why not try another course? Treat us fairly, deal justly by us, and perhaps this widening chasm between the city and State may be bridged. Things cannot go along as at present. The city will not consent-cannot consent to this perpetual tyranny of the rural districts."

${ }^{1}$ Ibid., Nov. 8, 1865.

${ }^{2}$ New York Herald, Nov. 8, i8c6. Bennett neutralized his influence with the Radicals and Conservative Republicans by denouncing the excise. The World (a) and the Herald (b) had an amusing postelection clash; the former taunted the latter with failure to exert any influence upon the election, which was hotly denied. (a) New York World, Nov. 7, 1866. (b) New York Herald, Nov. 8, i866.

${ }^{8}$ New York World, Nov. 8, i866.

' New York Herald, Nov. 8, i866: New York Tribune, Nov. 9, I866: New York Times, Nov. 9. 1866. 
The Democratic or National Unionist organs found it difficult to adjust themselves to defeat. Mr. Cassidy of the Argus suggested that the mission of Democracy was to hasten the national cure by precipitating the crisis. ${ }^{x}$ The Argus, with the Hudson Register, the Newburgh Press, the Troy Press and the Utica Daily Observer, devoted their editorial attention to showing that the Republicans had used large sums in the State and Congressional elections. ${ }^{2}$ These charges were rebutted by claims of heavy bribery in the Denocratic districts and New York City. The Rochester Dail" Democrat gave Messrs. Weed, Seward, Pruyn and Cassidy the credit for furnishing the major portion of the National Unionist funds. ${ }^{3}$ The Syracuse Daily Courier and Union was the least depressed of all the Democratic journals. "We have met the enemy and we are truly theirs," read the graceful tribute; "Truth has once more been crushed to earth, but we have the proverbial assurance that it will yet rise again and prevail." 4

The signal failure of the Democratic and Conservative coalition, under the guise of the National Unionist party, gave the Republican papers rich food for editorial reflection. " "Loyalty must rule and traitors take back seats." 6 "Democracy has received an opportunity to unboson itself. There is a clance for the display of its righteous indignation." 7 "New York State and the country have

'Albany Argus. Nov. 8, i866. Cf. Hudson Register, Nov. 7, I866, et seq.; Newburgh Press, Nov. 7, I866, et seq.; Troy Press, Nov.7. 1866, et sea.

'Utica Daily Observer, Nov. 9, 1866.

${ }^{3}$ Rochester Daily Democrat. Nov. 8, 1866.

4 Syracuse Daily Courier and Union. Nov. 8, 1866.

' Rochester Daily Democrat, Oct. I6, I866; Nov. 8, 1866.

${ }^{6}$ Binghamton Daily Republican, Nov. Io, 1866.

'Syracuse Daily Standard, Nov. 7, 1866. 
escaped from a dictator." " "Mr. Johnson-take heed." These sentences give the gist of the Republican sentiment. At greater length the Buffalo Express declared that "the voice of the people has been overwhelmingly declared against Andrew Johnson, his 'policy,' his pet rebels, his 'pseudo-conservative' ring of office-hunting politicians and the revarnished Democratic party to which he has returned as a dog to his vomit." 3 Carroll E. Smith confined his remarks chiefly to the election on the State: "The corrupt practices of the Common Council chambers of the metropolis will not be transferred to the larger sphere of the legislative halls at Albany." "4 The Albany Evening Joumal confinech its views to still narrower space. It advised the Conservatives and War Democrats of the metropolis that they still had some cause for thanksgiving that the "intelligence and patriotism of the rural districts" had saved the State from the social vandals." 5

\section{The New York City Cifarter Election of i866}

The State elections were hardly a matter of history before the local politicians of New York City began to prepare for the City Charter election, which was held on December 4, r866. The leading office was that of comptroller of the City; in all there was a total of ninetytwo offices to be filled. ${ }^{6}$ The number of candidates for

${ }^{1}$ Utica Morning Herald, Nov. 8, 1866.

${ }^{2}$ Ogdensburg Daily Journal, Nov. 7, 1866.

${ }^{3}$ Buffalo Express, Nov. 9, 1866.

- Syracuse Daily Journal, Nov. 7, 1866.

${ }^{5}$ Albany Ezening Joumal, Nov. 8, 1866.

${ }^{6} \mathrm{Nine}$ aldermen, an entire board of councilmen, twenty-four in number, seven school inspectors, and two school trustees in each ward, forty four in all. 
office created considerable interest in each ward, but on the whole the campaign proved dull. The chief interest centered in the office of comptroller. Matthew T. Brennan, the incumbent, despite great pressire brought by the Ring, refused to accept a renomination.' Brennan had been vigorously assailed by the Republican organs? and the Citizens' Association for malfeasance in office. Charges of criminal misappropriation of funds had been brought against him, to investigate which Governor Fenton appointed a commission. Comptroller Brennan denied these charges ${ }^{3}$ in a long letter of justification, and brought charges of corrupt practices against the "young lawyers" ${ }^{4}$ in charge of the Citizens' Association.

Although Greeley had demanded a Democrat for the anti-ring candidate, ${ }^{5}$ the Republican party selected Judge Richard Kelly, a man of integrity and independent tendencies. ${ }^{6}$ Tammany and Mozart Hall chose a loyal son

'New York World, Nov. I7, I866. The most fagrant charge against him was the presentation, without autliority of law. of $\$ 50$, cco from the Treasury as a "testimonial" to Orison Blunt for his "1 atriotic services in having the quola of soldiers due from the city, in that dark hour of our country's peril, reduced nearly one-half." New York Tribune', Nov, 28, I866.

${ }^{2}$ New York Tribune, Nov. 28, 1866.

${ }^{3}$ Brennan claimed that his innocence had been proven beyond dovtet in the case brought against Corporation Counsel Develin.

'New York World, Nov. 20, 1866.

${ }^{5}$ New York Tribune, Nov. I2, 1866.

${ }^{6}$ Bennett in his issue of Dec. 2, I866, ridicules Greeley for his fornicr and present opinion of the character of the Republican candidate. The Herald took little interest in the campaign (New York Herald, Dec. 2, I866) because Bennett thought the candidates were all equally bad. Greeley threw himself open to further ridicule, later, by his high recommendation of George G. Barnard as a possible candidate.

The Times spoke of Kelly as a man "of energy and good administrative ability." Mr. Kelly had held the office of police justice for several years. In 1863 he was re-elected in a district usually giving about a 4000 Democratic majority. 
in Richard B. Connolly, of whom we shall hear more. The other Democratic organizations were divided between Richard B. Connolly and Police Justice Michael Connolly, ${ }^{2}$ the irregular Democratic candidate. The Citizens' Association put up no regular candidate. Except the Tribune, the Republican papers in the City took little interest in the affairs of the campaign. ${ }^{3}$ The campaign was carried on at sniall ward meetings. The main demand from the Radicals, Conservatives and Independent Democrats was for an honest administration of the City's finances, while the Democrats hurled back the charges of dishonesty.

Public interest on election day was unusually slight. This fact is shown by the total rote for comptroller, which numbered only $71,595 .^{4}$ This was a trifle over half the total vote polled for the Governor one month previous. The Tammany candidate, Richard B. Connolly, as most expected, was elected. His majority over Richard Kelly, the Republican candidate, was 2,066.5 The reason assigned for the low Democratic vote was that the impression prevailed among them that the Albany legislature intended to nullify the result of the election by a complete reorganization ${ }^{6}$ of the financial department of New York City. Among the better class of citizens

'New York Times, Dec. 2. 1866. Richard B. Connolly had held the office of county clerk for two terms and had been twice elected to the State senate. He was regarded by his associates as a "good-fellow" but uncertain.

${ }^{2}$ New York Times, Dec. 3, 1866.

${ }^{3}$ New York Tribune, Dec. 5, 1866.

${ }^{+}$New York Tribune, Dec. 5, 1866.

${ }^{5}$ Ibid. The Tribune, Nov. 12, 1866, said of him: "He is a man of decided shrewdness and energy, widely popular, and a determined foe to the corruptionists.'

'New York World, Dec. 5, 1866. 
of all parties the sentiment appeared current that it mattered little what men filled the City offices-that whaterer was the political complexion of the office-holder, they were all involved in a system of public plunder. ${ }^{x}$

Apropos of the City elections the World complacently remarked, "Our citizens are sure of an able, honest and economical administration of the Comptrollership." Greeley assured himself that "The lesson of defeat, if well studied, may be applied at some future time to a contest in earnest and a victory therefore assured." 3 Of the nine aldermen elected, three were Republicans and the rest Democrats. Although in a hopeless minority, Don Alonzo Cushman, a wealthy and respected merchant, with William B. White and Eugene Ward, both prominent anti-fraud men, gave the Board of Aldermen "an element of intelligence to which it has been almost a stranger." 4

${ }^{1}$ New York Times, Dec. 3, I866.

${ }^{2}$ New York World, Dcc. 5, isi6.

${ }^{3}$ New York Tribune, Dec. 5, I8j6.

"Ibid. 


\section{CHAPTER VI}

The Senatorial Election of 1867.

The Chicago Times ${ }^{1}$ of November I2, I866, asks the question: "Shall the Democratic Party Die or Live?" Subsequent events have proved that there was never a question of the permanent disruption of the Democratic Party. But, to the Democrats throughout the nation, and especially in New York State, the question as to their solidity was a serious one, as it has been at later times.

The fact that a Republican legislature had been returned, immediately centered public eyes upon the campaign for a successor to Ira Harris in the United States Senate. The political pot among the various factions of the Republican Party was soon boiling. The field narrowed down to six contestants. The editor of the Tribune, ever a candidate for office. ${ }^{2}$ was among the first to announce his candidacy. In the Newburg Journal one finds a letter from Horace Greeley dated November I4. I866, in which he says: "I stall certainly accept the Senatorship, and endeavor to discharge its duties should I be elected. And I shall be gratified to learn that our newly chosen Legislature shall judge me the man for the place." ${ }^{3}$

Foremost among the Republican candidates was Charles

'Quoted in New York Times, Nov. 15, 1866.

"He had just been' badly defeated for Congress in the Fourth district by Mr. John Fox. However, it is no more than fair to Greeley to state that he did not expect an election, nor did anyone else, for the district was overwhelmingly Democratic.

s Newburg Journal. Nov. 15, I866. Dated from the office of the Tribune, on Nov. 14, 1867. 
J. Folger formerly a county judge and at that time the president and leader of the State Senate where he had served for a number of years. Folger "was an excellent lawyer, and impressive speaker, earnestly devoted to the proper discharge of his duties, and of extraordinarily fine personal appearance. ... He was greatly beloved and admired, yet, with all his fine and attractive qualities, modest. and even diffident, to a fault." 1

Senator Ira Harris was graduated from Union College with first honors in I824. He was elected to the State legislature in $18+4$ and was a member of the constitutional convention in $18+6$. In the fall of 1846 , he was sent to the New York Senate, but in the spring resigned his place for a seat on the bench of the State Supreme Court. He was re-elected for eight years in $185 \mathrm{I}$. Beating such worthy competitors as William M. Evarts and Horace Greeley, he was elected to the United States Senate for New York in I86I, where he became a close personal friend of President Lincoln. While his service in the United States Senate was not conspicuous, he was noted for his industry. ${ }^{2}$

Roscoe Conkling grew up in an atmosphere of law and politics. ${ }^{3}$ He had great mental capacity but small desire for

${ }^{1}$ S. R. Harlow, S. C. Hutchins, Life Sketches of State Officers. Senators and Assemblymen of lew Fork in 1868. pp. 81-4. Folger later became Chief Justice of the Court of Appeals and Secretary of the Treasury under President Arthur.

"History of the Bench and Bar New York, (New York, I897), vol. i, p. 35t. The IVorld, after appreciating Senator Harris for the integrity of his private character and upright citizenship, says: "But he has little energy either of mind or character, no breadth, no capacity for leadership, no strong grasp of any great subject, nor even any of that stirring, inquisitive activity by which mediocre talents are sometimes enabled to act a prominent, though not a great part in public transactions." New York Wrorld. Jan. 10, 1867.

s Alfred R. Conkling, Life and Letters of Roscoe Conkling, pp. 7-12. Conkling's father had been United States District Julge for twentyseven years. 
the academic halls. His desire for college was ever topped by an anxiety for real endeavor. He followed his father's profession, and was admitted to the bar before he was quite twenty-one. ${ }^{1}$ Shortly after he was appointed to fill a vacancy in the office of district attorney of Oneida County, and was renominated as his own successor in the fall. Inder protest his friends nominated and elected him mayor of Utica in 1858 . The following autumn, without solicitations on his part, he was offered the nomination for Congress. He was renominated four times for the same position, twice successfully. ${ }^{2}$

Noah Davis, after his admission to the bar in I $S+\mathrm{I}$, formed a partnership with Sanford E. Church at Albion, New York. In 1857 he was appointed by Governor King to the Supreme Court of New York, an office to which he was twice re-elected." While the frorld accredited him with being a "jurist of more than ordinary ability", still it prejudicerl his cause by urging that he was "a Judge who, while in office, with all before him of theory and example to advise to the contrary, has attended political conventions and has been active as a politician."

Lyman Tremaine had held local offices and in I $8+7$ was elected county judge but refused the certificate of election because of fraud in the voting. In 1857 he was elected attorney-general on the Democratic ticket. Joining the Unionist ranks at the outbreak of the Civil IVar, he was nominated by them for lieutenant-governor in I862, and was elected to the Assembly in I865. The conviction of

1 Alfred R. Conkling, op. cit., p. 64-4.

Ibid., pp. 644-5. The I'orld, Jan. 9, I867, placed Roscoe Conkling and Charles J. Folger in an intellectual class beyond all others named in the Senatorial race.

'The National Cyclopaedia of American Biography, vol, i, p. 236.

- New York IVorld, Jan. 9, I867. 
Tweed was largely due to his ability as a lawyer. ${ }^{1}$ When Mr. Tremaine withdrew from the Senatorial race he gave Conkling his support. ${ }^{2}$

A seventh candidate was suggested by a number of papers-George William Curtis, editor of Putnam's Maga. zine and of Harper's Weckly. Curtis was a distinguished student and litteratcur. As a delegate to the national conventions of 1860 and 1864 , he had been in active connection with national movements in politics. In the latter year he had failed of an election to Congress upon the Union ticket. Although expecting defeat, he had used his candidacy in 1864 to strengthen Lincoln. ${ }^{3}$ In the election of 1866 , he was chosen as a delegate-at-large to the New York State Constitutional Convention.

The above gentlemen formed the nucleus for one of the most intense and interesting Senatorial campaigns in the history of our State. It should be stated in passing that the candidacies of Supreme Court Justice Ransom Balcom, of Binghamton: Mr. Calvin T. Hulburd, ${ }^{+}$of St. Lawrence Connty, a politician of some local note: and Mr. Thomas G. Alvord, ${ }^{5}$ the Onondaga Chief, were not seriously considered outside of a few respective friends. The suggested services and abilities of the several candidates were sufficient to insure a contest worthy of the name. It was the death grapple between the old and the new elements in the Republican Party.

Mr. Greeley's early position of vantage in the Senatorial

${ }^{1}$ The Mational Cyclopaedia of American Biography, op. cit., pp. 236, et seq.

- New York Herald, Jan. 8, I867.

${ }^{3}$ Cary, Georgc Il'illiam Curtis (New York, I894), pp. I83-5.

- New York H'orld. Jan. 5, i867.

${ }^{5}$ The New York Herald, Jan. IO, I867, mentions that Alvord is still in the fight with ten or twelve rotes pledger. 
fight was blasted by his candid statement to the effect that he desired general annesty. ${ }^{1}$ The revengeful class among the Radicals at once dropped his candidacy from any consideration which they may have given to it. George William Curtis, foreseeing the result, "declined absolutely " 2 to enter into a combination with Davis to beat Conkling. Before the caucus, Curtis withdrew his name in favor of Conkling. Realizing the futility of his own candidacy, Charles J. Folger, also, withdrew, preferring to preside over the caucus, so that the duty of seconding Conkling's nomination was placed with Andrew D. White. ${ }^{3}$

The belief among those not interested in any of the candidates veered towards the opinion that nothing short of the unexpected could throw the election to Judge Harris for the second time. The friends of Senator Harris took a much bolder and more active course in this campaign than when he was chosen in I86I. ${ }^{4}$ For obvious reasons it was foreseen that if Harris was not chosen on the first ballot. his supporters would gradually melt away. This was what happened.

Between Daris and Conkling the odds, to use sporting parlance, were slightly in Davis' favor without any apparent reason. Although the personal qualities of Judge Davis were high and universally adnitted, still at that time he had none of those claims founded upon sacrifice and long ser-

1 New York Sun, Jan. I I, 1867.

'Cary, op. cit., p. 193.

3. Altoliography of Andrew D. White, vol. i, p. I35.

${ }^{4}$ New York Horld. Jan. 9, I867. The I'orld put it: "Then [I86I] his friends, with great sagacity, meekly stood aside, tendering their kindest regards to both Messrs. Evarts and Greeley, admiring their strength of wind and muscle, praising the dexterity with which they pounded each oiher, and suggested their own camp as a quiet and pleasant resting place" ... 
vice for the common cause. ${ }^{1}$ However, Davis had the speaker of the Assembly on his side. ${ }^{2}$ It was claimed that the commitee which handled the nomination was so constructed as to lend additional strength to Davis." The quiet air of confidence assumed by the friends of Davis soon wore off, for Roscoe Conkling, who had been proposed for the vacancy by the press of the State during the previous December, ${ }^{*}$ proved to have the support of the younger and more progressive element in the party.

The attitude of Governor Fenton in the campaign was one which puzzled many. It was a natural inference, advanced by practically all, that he wished the nomination of a candidate from the east-thus to prepare the way for himself two years later in the west. In reality he was forced to favor Davis of the west in order to thwart the rise of Conkling. Mr. Conkling made a serious error, at first. in his canvass. He believed that the apparent support of Davis by Fenton was only a blind, and that Fenton really favored Senator Harris. Hence, the Conkling canvass was conducted on a basis of Conkling versus Harris. It was not long, however, before some of Conkling's friends discovered their mistake. Conkling refused to believe it until the caucus was on. It was claimed after the election that five or six Senators, with an equal number of Assemblymen, cast their votes with the purpose of punishing the Governor, a thing they would not have done under other circumstances." "The fact of the matter is, the real contest

1 The Democratic estimate of Judge Davis was meant to be all inclusive. What his qualifications were the Il'orld could not describe, "the political microscope being an instrument with which we seldom have time to amuse ourselves." New York IVorld, Jan. I0, 1867.

- New York Times, Jan. I2, I867.

Ibid.

- Alfred R. Conkling, Life and Letters of Roscoe Conkling, p. 285.

${ }^{3}$ New York H'orld, Jan. I2, 1867. 
was not Conkling and Davis, but Fenton and antiFenton." Governor Fenton realized that the success of Conkling would be a death-blow to his own political future. Mthough the Governor and his friends preferred Senator Harris as more amenable to discipline, still they threw their interests on the side of Judge Davis in the hope of breaking the Conkling combination. It was not until Conkling's friends cante to a full realization of this in the caucus, that sufficient headway was made to secure success.

nother factor in the canvass was the enmity engendered among the friends of ex-Lieutenant-Governor Alvord and Mr. Bruce against Fenton, to whom they ascribed the defeat of Alvord and Bruce for renomination at Syracuse. $^{2}$ They wished to have revenge on Fenton.

Crowded galleries greeted the caucus when it assembled at seven o'clock on the evening of January Ioth. Senator Low called the assemblage to order and nominated Senator Charles F. Folger as chairman. The roll call found every nember present with the exception of one Senator. ${ }^{3}$ It had been arranged for Ellis Roberts, ${ }^{4}$ an able editor from Conkling's Assembly district, to present the latter's name. In his speech Mr. Roberts argued that " the great State of New York, which had been so long silent in the highest conncils of the Nation, demanded a roicc "." The greatest

1 New York Horld, Jan. 12, I867.

- It was an open question as to how long the Syracuse and Oneida interests could work together smoothly.

I 108 members answered. Senator Parsons was confined to bed and allowed to vote by proxy.

- Roberts had graduated from Yale with high honors. He threw the strength of his paper, the Utica Horning Herald, into the campaign with such ardor and ability, that he was able to line up most of the Republican up-State papers for Conkling.

s Autobiography of Andrew D. White, vol. i, p. I35. 
outburst of the evening occurred upon the mention of "a voice ". Mr. R. L. Burrows, of Erie, then placed in nomination Judge Davis. This speech, too, was powerful, but it was noticeable that Mr. Burrows rested his claims for Davis upon the staunch Republicanism of the district from which Judge Davis came, rather than on the ground of past services such as had been pointed to in connection with Mr. Conkling. Mr. Burrows urged that during the whole history of New York there had never been a United States Senator chosen by any party from a portion of the State west of Cayuga Bridge. ${ }^{2}$

Mr. Smith, of Albany, placed Senator Harris in nomination, praising him for his character and past services. Horace Greeley was nominated by Mr. Travis, who declared that the Republican Party owed more to Mr. Greeley than to any other living man. Mr. Travis also stated that he made the nomination without consulting Greeley, for the latter kept away from Albany believing that the office should seek the man and not the man the office. ${ }^{3}$ A friend nominated Judge Ransom Balcom, of Binghamton.

The nominations having been completed, Mr. Parker, of Cayuga, at once moved for the informal ballot. Senator White and Assemblymen Tarbox and Shotts, acting as tellers, found Conkling in the lead with one vote. The Davis men looked jubilant over his strength. The sup-

1 As indicative of the general desire for "a voice" in the national councils we may quote a reply made by Ezra Cornell, founder of Cornell University, after a visit to Washington. "While at the Capitol I was ashamed of the State of New York: one great question after another came up: bills of the highest importance were presented and discussed by Senators from Ohio, Vermont, Missouri, Indiana, Iowa and the rest: but from New York never a word." Autobiography of Andrea D. White, op. cit., p. I33.

- New York Herald, Jan. I I, I867.

- New York Sun, Jan. II, I867. 
porters of Conkling and Harris scattered and vied with one another in canvassing for votes. In the midst of the confusion Mr. Travis withdrew the name of Horace (ireeley.' A motion for a second informal ballot was changed by amendment to call for a formal vote. This move, forced by the Davis contingent, gave his supporters additional hope. On this vote Davis drew forty-one votes to thirty-nine for Conkling. It was evident that the friends of Senator Harris were wavering. By the next ballot the excitement had increased to fever heat. The situation between Conkling and Davis shifted slightly in favor of the former by one ballot. On the next vote, big gains were made at the expense of Harris by both leaders. Conkling increasing his lead by two. Two votes only were needed to give Conkling the Senatorship. Every Harris man was at once surrounded by Conkling and Davis canvassers. The vote was thrown out, however, as some one, probably through design, deposited an extra ballot. Another and the final vote was taken which resulted in an election for Conkling." I popttar demonstration was given to Senatorelect Conkling at the Delevan House immediately upon the adjournment of the caucus. He was carried through the corridors on the shoulders of his friends. Lyman Tremaine voiced the general sentiment of those who crowded to congratulate Conkling when he said that the election

' New York Tribune, Jan. II, 1867.

' New York Tribune, Jan. II, I867.

Five ballots were taken as follows:

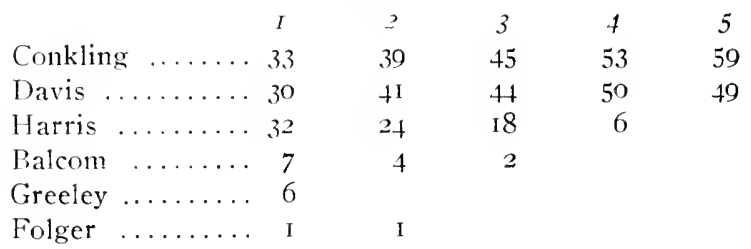


"showed plainly that henceforth the young, vigorous, live men must rule. . . I It was a triumph not of gold but of intellect, against age and mediocrity." 1

While the Republican caucus was sitting, a similar meeting was held in another part of the Capitol building. The Democratic caucus was small and unenthusiastic. The form of nominating a Democratic Senatorial candidate was followed out. Mr. William Williams, of Erie, was chairman of the caucus. Mr. Henry C. Murphy, of Kings, was nominated by Mr. Jacobs of the same county. Mr. Develin insisted, in spite of the desire to make the meeting strictly harmonious, on nominating A. Oakey Hall, of New York, to show him the regard of the New York City members. An informal ballot gave Murphy twenty-five votes to twenty-one for Hall. The latter's name was then withdrawn and the nomination of Mr. Murphy made unanimous. A slight breeze was stirred up in the caucus over the question-what to do if the votes for Murphy were thrown out because he was at present a member of the State Senate. $^{2}$ This furnished a suitable vent for the feelings of a few strenuous members and then the question was withdrawn. Mr. Murphy appeared at once, and briefly but eloquently thanked the caucus for the honor. ${ }^{3}$

The Republican caucus elicited the usual rumors that large sums of money had been in evidence as an influence in the election. Yet we have Conkling's word to his wife that he had been elected honestly.

${ }^{1}$ New York Tribune, Jan. II, I867.

- The Democrats were not to escape for this indiscretion. The Daily Democrat commented on the nomination of Mr. Murphy: "The Democrats have shown the hollowness of their regard for Constitutional restraints by voting for a candidate who as State Senator is confessedly ineligible and for whom all votes are void. They pretend to be the friends of the Constitution." Rochester Daily Democrat. Jan. I6, I867.

- New York Herald, Jan. II, I867. 
Great sums of money ${ }^{1}$ are among the influences here. I have resolutely put down my foot upon the ground that no friend of mine, even without my knowledge, shall pay a cent, upon any pretext nor in any strait, come what will. If chosen, it will be by men of character, and if beaten, this will be my consolation."

Conkling's rise had been meteoric. Andrew D. White states the reason which led him to advocate the candidacy of Roscoe Conkling.

Judge Bailey, of Oneida County, had called my attention to the claims of Mr. Roscoe Conkling. . . . He had, to be sure, run foul of $\mathrm{Mr}$. Blaine.... and had received in return for what Mr. Blaine considered a display of offensive manners," a very serious oratorical castigation;" but he had just fought a good fight ${ }^{5}$ which had drawn the attention of the whole state to him. He had shown himself equal to the emergency.... I had watched lis course closely, and one thing especially wrought powerfully with me in his favor. The men who had opposed him were of the same sort with those who had opposed me; as I was proud of their opposition, I felt that he

1 Alfred R. Conkling, Life and Leticrs of Roseoe Conkling, p. 287. "The gamblers say that I can have $\$ 200,000$ here from New York in a moment if I choose, and that the members are fools to elect me without it."

: Alfred R. Conkling, op. cit., p. 286.

Congressional Globe, 39th Cong., vol. iii, p. 2298.

- Ibid., pp. 2298-9. On April 30, 1866.

${ }^{5}$ The anti-war Democrats, in conjunction with a number of disaffected Republicans in his district, combined to defeat Conkling's reelection to Congress. The New York Tribune gave him no effective support as was expected from the leading organ of the party. The reason appeared later, when it became known that Greeley was a candidate for the United States Senatorship. For a time it looked as if Conkling would be driven from public life. The whole number of voes cast in the district was 23.523, of which Conkling received I 2,470 and Palmer V. Kellogg I I,053. Alfred R Conkling, op. cit., p. 281 . 
had a right to be so. The whole force of Tammany henchmen and canal contractors throughout the state honored us both with their enmity. ${ }^{1}$

While the more gallant of the Democratic Party congratulated the people on the fact that they would " now be heard in the United States Senate Chamber in a manner which will make the old state feel proud ", there were others of the Democratic faith not so generous. The World, rebutting the above statement of Andrew D. White, charged that the combination which had elected Conkling "was made up of the canal men, canal commissioners, the Oneida and Syracuse interests" and it also hinted at rumors of impeachment of the "Canal Ring officials . . . with an exhibition of dirty linen on all sides, which will amuse if not interest the Democracy "." The World foresaw the formation of a "ring" in the Republican Party under Conkling, which would lead to the party's disruption, and the return of the Democrats to power-hence it was jubilant. ${ }^{4}$

During the course of the Senatorial campaign, the Tribune was strangely silent on the matter of the United States Senatorship until the morning of January I I, I867, when it gave a full and fair account of the previous evening. It spoke of Conkling as " a most effective debater and canvasser, an unflinching Republican and a most devoted and efficient champion of Protection to Home Industry ".

1 Autobiography of Andrez D. White, vol. i, p. I35.

' Cf., excerpts in Alfred R. Conkling, op. cit., p. 289.

- New York Horld, Jan. 12, 1867.

- Another charge of the IVorld was that it had been agreed with Ezra Cornell, of Tomkins County, that he should be the next Republican nominee for Governor. Cornell during the Senatorial canvass, the World claimed, subscribed $\$ 50,000$ to Dana's paper in New York.

s New York Tribune, Jan. II, 1867. 
The editorial comment of the New York Hcrald on the Sentatorial choice was noticeable by its complete absence.

Harper's I'eckly briefly commented-." Mrr. Thurlow Weed has joined the Manhattan Clul), and Mr. Roscoe Conkling is elected Lnited States Senator ". ${ }^{1}$ The tribute of Harper's IVcekly to Conkling was whole souled.

In Roscoe Conkling the State of New York has a Senator who truly represents the spirit and tendency of her regenerated political principle and policy. Young, fearless, devoted, able: of the profoundest convictions: of much experience acquired in critical and stormy times: with all his brilliant powers disciplined and available, the country no less than the state will find him a man equal to the hour. ${ }^{8}$

Of an entirely different hue was the estimate of Conkling given by the IVorld. " He has a fair intellect, a bumptious kind of self-importance, and a restless desire to make a figure, which will perpetually spur him on to make a display of his talents such as they are. That his radicalism is a little deeper seated than that of Mr. Harris, is of no consequence. since he does not carry guns enough to be a party chief ". The predictions of the lVorld proved true so far as it concerned national leadership. ${ }^{4}$ It is doubtless,

${ }^{1}$ Harper's Hiekly. Jan. 26. 1867, p. 50.

I Ibid.

3 New York II'orld, Jan. 10, 1867.

- The Diary of Gideon l/'elles (Boston, 1911), vol. iii, p. I6. Gideon Welles in his estimate of Conkling spoke of him as vain, "with touches of spread eagle eloquence, and a good deal of impetuous ardor." Speaking of Conkling, George F. Hoar says: "He was an able man, though not superior in his ability to some of his associates.. He was undoubtedly a strong man... But he was unfit to be the leader of a great party. and was sure, if he were trusted with power, to bring it to destruction. He was possessed of an inordinate vanity. He was unrelenting in his enmities and at any time was willing to sacrifice to them his party and the interests of the 
no more than fair to say that had Conkling not prematurely severed ${ }^{1}$ his close relations with national affairs, his infinence over the Republican Party would have been greater.

The editorial interest of the State journals in the outcome of the Senatorial contest at Albany was not so marked as that of the New York City papers. The Rochester Daily Democrat appears to have believed that Mr. Davis had not sanctioned the use of his name, which was utilized for commercial purposes to aid Senator Harris." "A Radical through and through " ${ }^{3}$ Conkling gave the Radicals of the State full satisfaction." The Utica Morning Herald, Conkling's home paper, emphasized the point that the election had been won by fair means." The few State journals of Dennocratic alliance which noticed Conkling's election editorially

country." Autobiography of Seienty lears (New York, 1903), vol. ii, p. 55. Col. A. K. McClure, Recollections of Half a Century (Salem. Mass., I902), P. IJo, reporting his conversation with Conkling after the latter had been defeated in his endeavor to nominate Grant over Blaine. Sherman and Garfield in rs8o, says of him: "Conkling, imperious asa Roman Emperor, could not accommodate himself to defeat, and when I spoke to him later in the evening about the political situation, and what New York would be likely to do as to the VicePresidency, his answer was quite too sulphurous to be recorded in the public press."

1 An extremely interesting and full account of the incidents attending Conkling's fall may be found in: Alexander, Af P'olitical History of the State of Yeze York, vol. iii, pp. 428-82.

2 Rochester Daily Democrat, Jan. 8, I867.

- Ogdensburg Daily Journal, Jan. 14, 1867.

- The following Rarlical Journals especially endorsed Conkling: Buffalo Commercial, Buffalo Adiertiser, Buffalo Express, Binghamton Daily Republican. Syracuse Daily Journal. Syracuse Daily Standard, Ogdensburg Daily Journal, Utica Morning Herald. Auburn Adrertiser. Albany Eaching Journal (see, Jan. II, 1867), Albany E.rpress, and Rochester Daily Democrat.

${ }^{5}$ Utica Morning Herald, Jan. II, 1867. 
gave a note of quasi approval, the Argus reminding the people that Conkling's faults were still those of youth. ${ }^{1}$

On March 23rd, Conkling delivered his maiden speech in the Sente in connection with the proposed impeachment of Henry A. Smythe, Collector of the Port of New York. ${ }^{2}$ The Tiashington Chronicle spoke of his effort thus: "Roscoe Conkling then rose, and for twenty-five minutes electrified the Senate with a clear and convincing defense and justiication of the New York Representative." When he had concluded, the Senate was checked in its purpose to treat the House imperiously ".. " Roscoe Conkling," said the Chicago Republican of March 28th, "the new member from New lork, . . . though the youngest man, as well as the youngest Senator, on the floor, is already the leader of the Senate." "The position of Conkling in the political life of New Jork fell nothing short of leader. For over a decade he was the ruling figure among the dominant faction of the Republicans.

1 Albany Argus, Jan. 11, I867. Utica Daily Obscrier, Jan. II, I867. Rochester Daily Inion and Adiertiser. Jan. 8, I1, 1867.

2Gideon Welles speaks of Smythe as a useless politician and an indifferent public officer. President Johnson later nominated Smythe for the Austrian mission. The Diury of Gideon H'elles, vol. ii, p. 5.8 ; vol. iii, p. $39 \mathrm{I}$

3 Mr. Calvin T. Hulburd, of St. Lawrence County, who was at the head of a House Committee of Investigation

- Washington Chronicle, March 28, I867. Quoted in Alfred R. Conkling. op. cit., p. 29 I.

- Chicago Republican, March 28, 1867. Quoted in Ibid., p. 291. Cf. Shelby M. Cullom, Fifty Ycars of Public Seritic (Chicago, I9II), p. II6 et seq. 


\section{CHAPTER VII}

\section{The Conventions of I 867}

To the uninitiated the Union Republican State Convention, which met at Syracuse on September 25, I867, appeared harmonious. Nevertheless, the feeling of envy over Conkling's rapid rise had created a chasm between the supporters of Fenton and Conkling's friends. A secret understanding was discovered by the Conkling men, in the nick of time, having for its purpose to place the control of the permanent organization in the hands of Fenton, with Lyman Tremaine in the chair. But innmediately upon the announcement of the committee on permanent organization, Senator Edward M. Madden jumped to his feet and placed before the convention a resolution which instructed them to report the name of Hon. Roscoe Conkling as president of the convention. The Fentonites, taken completely by surprise, saw at once that it was a case of "play ball". Not desiring to have an open break with Conkling at this time, they accepted him as permanent chairman. "This was a point 'scored' on the friends of Governor Fenton." 1

Among the more prominent of those in attendance at the convention were Horace Greeley. Andrew D. White, Senator Roscoe Conkling, General Leavenworth. General Van Wyck, Chauncey M. Depew, Charles S. Spencer, leader of New Irork City Radicals, and Rufus W. Andrews, who led the delegation of New York City Conservatives. ${ }^{2}$ A double

1 Alfred P. Conkling, Life and Letters of Roscoe Conkling, p. 296.

a Among others were: Ex-Surveyor Andrews, present Surveyor Wakeman, Waldo Hutehins, E. Delafield Smith, Senator Thomas Murphy. 
delegation from New lork City, composed of Radicals and Conservatives, sought to gain recognition in the convention. The latter were those who had attended the Philadelphia Convention and had remained away from the last Republican State Convention. Sins of no deeper dye than these might have been forgiven or at least overlooked by the Radicals, but this Twenty-third Street party ${ }^{1}$ under Thomas Murphy and Thurlow IVeed had dared to work actively for the election of Hoffman and Pruyn against Fenton anicl Woodford in the last election. Such treachery must needs be atoned for. There appeared to be excellent social fellowship between the rival delegations. Neither of the New York delegations manifested any desire to bolt the ticket if they received unfavorable action at the hands of the convention. The Conservatives desired to gain admittance to the convention by means of a compromise which would admit both delegations and allow them but one vote. The Radicals, however, were firm in their demand that punishment be meted out to the backsliders. The leader of the Radicals was heard to remark that "if the Conservative delegation be admitted, the Radicals will withdraw in a body." ${ }_{2}$ There were comparatively few of the noisy brand of politicians at the convention. It was said to have comprised a stronger aggregation of influential men of the party than had been found for many conventions past.

The Radical delegation from New York and Brooklyn led the general feeling among the delegates, that there should be a complete new deal in the nominations. There was a feeling rife among the majority of the delegates that the present administration had favored their opposites in political faith. This feeling prevailed, in spite of the fact

1 New York Tribune, Sept. 24, 1867.

'New York Times, Sept. 25, 1867. 
that General Barlow and his colleagues in office had made numerous attacks on several corrupt gangs, notably the Canal Ring. The Times ${ }^{1}$ and the Commercial Advertiser ${ }^{2}$ were severe in their condemnation of the convention for permitting this perverse sentiment to rule. The latter hinted that there was a reason for the move which was alien to the best interests of the State and the welfare of the people. With the exception of the secretary of state. the New York City Radicals were not at all insistent in urging any candidate. For secretary of state, to succeed General Barlow, both the Radical and the Conservative delegations from New York urged the candidacy of Major General Lawrence, the officer who, when ordered by General Forrest to surrender Fort Columbus, ${ }^{3}$ had returned the famous reply - "I was sent to defend this fort and intend to do it "." He was, also, a nephew of the noted Captain Lawrence who covered the name Chesapeake with glory.

General Barlow's friends were in strong number, but to permit one of the old ticket to hold over would have looked like a rebuke to the others. So answered those who desired a change. General McKean, of Saratoga, was the only other candidate for the leading office. It was not thought at first that he would displace General Lawrence. For the lesser offices Charles J. Folger was mentioned to succeed Attorney-General Martindale. Ex-Senator Ferdon, of Rockland, and Colonel Robinson, of Elmira, were rivals for the State-prison inspectorship. Before the convention convened, Frederick Julian, of Chenango, was thought to have the best chance for state treasurer, but he went down

${ }^{1}$ New York Times, Sept. 26-27. 1867.

- New York Commercial Adrertiser, Sept. 26, I867.

- Upon the Mississippi a short distance above Fort Pillow.

- New York Times, Sept. 25. I867. 
to a bad defeat at the hands of General T. C. Gates, of Ulster. However, prior to the convention nothing was definite. The general disposition prevailed to forego the usual preliminary caucuses and allow the strength of the various candidates to show itself before the convention. ${ }^{1}$

The Tribune and the Albany Evening Journal were both in favor of administering punishment to the Conservative members. ${ }^{2}$ Their sole offense was that they had differed with prominent members of the party in the earlier stages of Reconstruction. The Times and the Commercial Advertiser condemned the Radicals severely, for throwing overboard capable and upright State officers. The Times, in a strong editorial, asked:

Is the Republican Party in this State so strong that it can afford to alienate any portion of its members and force them into a position of indifference if not hostility? Is the time propitious for such an experiment? Is there a necessity for reviving former differences, vitalizing dissensions, which events have in a great measure healed, and provoking quarrels in the presence of a united and powerful enemy ? ${ }^{2}$

The Times further suggested, in its endeavor to conciliate the jarring factions, that if one had shown a disposition to favor Johnson in the beginning it should be remembered that he had been elected by Union Republicans. The question whether one section of the party adhered to President Johnson a month more or less than another section was one

1 A convention of Germans widely advertised as meeting on September $24^{\text {th }}$ at Syracuse, with the object of inducing the Republican State Conven ion to recommend certain modifications of the laws, was poorly attended. New York Timles, Sept. 2, 1867.

- New York Tribune, Sept. 25-7; Albany Evening Journal, Sept. $25-7$.

- New York Times, Sept. 25, 1867. 
which did not offer " a valid reason for impugning the fealty, denying the honesty, or assailing the patriotism of the other. The pretensions of the Union League Club when sitting in judgment on Mr. Greeley for bailing Jeff. Davis, were not more preposterous than would be the claim of the convention to excommunicate those who have not in all things agreed with the majority of its members "." Thurlow Weed, now editor of the Commercial Advertiser, placed the responsibility for the unwise course of the Republican Convention on Horace Greeley. In an editorial on September $25^{\text {th }}$ he made a cutting assault on Greeley.

But for the evil it is doing .... it would be amusing to see the Tribune preach about party obligations. In its best days it was capricious and unreliable. During the twenty-five years of Whig service, it was always disturbing and distracting the party with its isms. In 1864 it labored to get up a Cleveland Convention to defeat the re-election of President Lincoln. It advocated Secession in 1860 . It played the bully and coward throughout the war, closing with an offer of $\$ 400,000,000$ as a bribe to Slavery for Peace. Only two years ago by its shameful opposition to M. O. Roberts, it secured the election of $\mathrm{Mr}$. Hoffman.... And this Tribune, an organ of Secession, that now demands Amnesty for all Traitors and Assassins: that opened the Prison Door for Jefferson Davis : that invites Breckinridge to return : that, after urging the President to appoint General Steedman-Secretary of War, stigmatized him as the most unfit man in the country for that position, arraigns and impugns the Republicanism of men through whose labor and care both the Whig and Republican Parties were ... preserved in their strength and integrity until the evil day of small things and cheap men....'

The dispute between the rival delegations from New

1 New York Times, Sept. 25, I867.

New York Commercial Adiertiser, Sept. 25, 1867. 
York occupied the convention for more than an hour. The leader of the Radicals, Mr. Spencer, read copiously from the article in the Tribune ${ }^{1}$ describing the antecedents of the "Twenty-third Street delegation". Rufus G. Andrews, the voice of the latter organization, offered to compare his own or the past record of his delegation with that of the Radicals. Mr. Andrews maintained his rights with such earnestness and persuasiveness that he was enabled to have a committee appointed by the convention to hear their claims. In this they "scored" on the Radicals, who, with the State committee, had planned to shut them out without even a committee hearing. Not only did the Twenty-third Street delegation obtain a hearing, but Mr. Gleason, chairman of the committee, frankly admitted in his report that there had been irregularities on both sides. He recommended to the convention that they adopt some action through which the various differences might be harmonized immediately.

This result was all the Conservatives desired. Mr. Andrews had told the convention as much, previously. He made a good-humored address of thanks and the Conservatives retired in a body well pleased. ${ }^{2}$ They professed to regard it as a triumph, for it had hardly been a part of their expectation to receive admittance to the convention. The Radicals' chagrin might have been greater, had the attempt made by Senator Madden, just previous to the adjournment of the convention, been successful. He moved for the passing of the special committee's recommendation, which would empower the State central committee to investigate the irregularities of the Radicals in New York City and to settle their differences, if possible. This motion was most

1 New York Tribune, Sept. 24, I867. Five thousand copies of the Tribune were brought to Syracuse for distribution in the convention.

- New York Times. Sept. 25, I867. 
strenuously opposed by Mr. Spencer and at length laid upon the table. Had it not been for the fact that a majority of the delegates had left the hall, it might have received a different fate.

Roscoe Conkling, upon taking the chair, delivered an address which was received with great enthusiasm. The speech was a "fervid and eloquent assertion of the principles and purpose of the great dominant party of the country". " "It is a party of ideas, not of privileges for a few but of human rights for all." ${ }_{2}$ Conkling gave notice of his intention to take "no one's dust". ${ }^{3}$ He pointed out that the Republican party had vindicated its claim to the Unionist support by its successful administration and unconditional triumph in the War. This it had done against all the odds of a sneering incredulity in Europe, the treachery of Copperheads and the frequent hesitancy of many friends. When Conkling asserted that the situation in national affairs demanded the use of impeachment for the Presidentthe enthusiasm of the convention knew no bounds. ${ }^{4}$ The Herald, editorially, termed the convention speech of Senator Conkling " as pitiful a piece of party fume as ever came to the dignity of print". ${ }^{5}$

'Harper's Veckly, Oct. Io, I867, p. 642.

"Ibid. 'New York Times, Sept. 26, I867.

4 An excellent example of Conkling's invective follows: "But in free America... we see bills vetoed and then when they become laws we see them evaded and defied upon preense that they are wanting in the very things for which the veto was put forth. We see the nation insulted by a message to Congress, intended to stab our financial credit, a message wickedly intimaing that by chastising traitors the American people have become liable to pay the debts of the lately rebellious states. In plain perversion of law, if not in open defiance of law, we see the removal of the unflinching Minister of War...." New York Times, Sept. 26, 1867.

' New York Herald, Oct. 5, 1867. 
When nominations became the order, Mr. Charles S. Spencer, of New York, proposed the name of General Hudson Lawrence, of New York, for secretary of state; Mr. D. D. T. Marshall placed in nomination General Francis C. Barlow, of New York, and Mr. John C. Green nominated General McKean, of Saratoga. The fight was on. The Radicals from New York, in spite of their loud clamorings for General Lawrence, apparently had little real desire for his candidacy, in face of a more available man. General McKean received 270, General Barlow, Ior, and General Lawrence 6 votes. General McKean's nomination was then made unanimous. As in the case of General Barlow, there was, also, a considerable feeling that the dropping of $\mathrm{Mr}$. Hillhouse would weaken the ticket. Those who desired a new slate used the same argument, that to retain one of the old names would be an implied censure of the administration of those who were dismissed. Judge Folger nominated Thomas C. Hillhouse, of Ontario, and Lyman Tremaine did the same for Calvin T. Hulburd, of St. Lawrence, for comptroller. The determination to have a new slate won. Mr. Hulburd received 238 to I 36 votes for Hillhouse. $^{1}$ The fight over the State treasurership was spirited.

${ }^{1}$ New York Times, Sept. 26, 1867.

Trcket. Candidates nominated were: General McKean, of Saratoga, Secretary of State; Calvin T. Hulburd, of St. Lawrence, Comptroller; General T. C. Ga'es, of Ulster. State Treasurer; Judge Vancoff, of Kings, Attorney General; A. C. Powell, of Onondaga, State Engineer: John M. Hammond, of Allegany, Canal Commissioner; Gilbert Delamater of Wyoming. Inspector of State Prisons: Charles Mason, of Madison, Judge of Court of Appeals.

Radical State Committee-H. Eastman, of Queens; C. H. Goddard, of Kings; H. N. Holt, of Kings; J. G. Abbe, of New York; W. H. M. Kenney, of New York: Martin B. Brown, of New York; Waldo Hutchins, of New York; Ira O. Miller, of New York; H. D. Roberston, of Westchester: E. M. Madden, of Orange; J. H. Ketchum, of Dutchess; John Lyon, of Ulster; Hamilton Harris, of Albany; H. J. King, of Rensselaer; Jerome Lapham, of Warren; E. A. Merritt, of 
Hon. Frederick Juliand, of Chenango, who was supposed to have the strongest following before the convention met, came in third with 27 votes to $\mathrm{I} 33$ for Mr. A. B. Cornell, of Tompkins, and 207 for General Gates. Erastus S. Prosser, of Erie, was a candidate, but before the result was announced he withdrew and threw the support of Erie County to Mr. Cornell. General Howland's name had been previously withdrawn upon receipt of a letter in whicin he declined to run for renomination.

The Commercial Advertiser condemned the Republican convention for throwing overboard capable and upright State officers.

Mr. Goodsell, the State Engineer, who, as a member of the Contracting Board, steadily and firmly resisted the corrupt awards of his colleagues, is as ignominiously dropped as was Alberger, the unworthy commissioner. Against Messrs. Barlow, Hillhouse, Martindale, and Howland, there was not a whisper of complaint.... There was a reason ... for this injustice. That reason, however, was alien to the interests of the State and the welfare of the People. ${ }^{1}$

The World claimed to see a dearth of candidates at the Republican convention and heartily endorsed those nominated

St. Lawrence; F. D. Curtiss, of Saratoga; Alvin Sturtevant, of Delaware; E. V. Livingston, of Lewis; C. H. Hopkins, of Oneida; J. B. Jenkins, of Madison; Isaac L. Endres, of Livingston; Adolphe Notte, of Monroe; W. H. Merrill, of Wyoming; John Sherwood, of Erie; G. W. Palmer, of Chautauqua; S. B. Garritt, A. B. Cornell, Luther Caldwell, and James Terwilliger.

Note-Mr. C. T. Hulburd upon reaching home on Oct. 17, 1867, after a four months' trip abroad, was first informed of his nomination in Ogdensburg. He decided to decline. This gave the Republican managers a cliance to redeem and bolster up their ticket in view of the cry against corrupt candidates by the substitution of Mr. Hillhouse, whose faithful services were well known. New York Commercial Adzertiser, Oct. 25, 1867.

1 New York Commercial Advertiser. Sept. 26, 1867. 
as "conspicuous neither for resisting official corruption, nor for anything else "." Greeley, however, consoled disinterested third parties by assuring them that- "It is quite distressing to see their tears over the State officers who were not renominated. . . . But we were not nominating Democratic candidates, nor in any manner trying to please that party." 2

The platform affirmed the right of impartial suffrage. It took strong ground against corruption and mismanagement in the affairs of the State and declared a "purpose to continue the work of administrative reform it had inaugurated; that it will steadily fight corruptionists and ever hold them its enemies; that it will urge war against them until corruption and maladministration are rooted out and destroyed. . . ." ${ }_{3}$ Emphatically declaring for the support of Congress and its policy, the platform most cordially approved Hon. Edwin M. Stanton in his conduct of office, and condemned, " as an insult to the nation", the removal of General Philip H. Sheridan and General Daniel E. Sickles. A sop was thrown to the church-going and temperance elements in a resolution for the entorcement of a quiet Sabbath and the excise law, this to be done, however, in such a manner as not to interfere with the liberty of the citizen. All endeavors to interfere with the financial obligations of the Union were repelled and rebuked, although the platform asserted the need for fairness and equality in the public burdens. The Union soldiers were recognized for their services and thanks were given to Governor Fenton and Senators Morgan and Conkling. The spirit of the platform was well stated by the watchword

${ }^{1}$ New York IIorld, Sept. 27. 1867.

${ }^{2}$ New York Tribune, Sept. 27, I867.

- New York Times, Sept. 26, 1867. 
inscribed upon the party banner-" National reconstruction through liberty and justice: State repose through integrity and economy ". ${ }^{1}$

Whatever may be said of the wisdom or discretion of the Convention, [declared the Sun] it certainly deserves credit for blunt honesty, for there is not an equivocal line or evasive word in the platform. . . . The suffrage plank in the platform ... a sacrifice of political strength on the altar of consistency ... will cost the party ten thousand votes."

The World, not so magnanimous as the Sun, asked-"When did it ever before happen that a political party adopted a platform condemning, not its opponents, but itself? Sunday liquor laws! Who passed them? Official corruption! Who perpetrated it? Negro suffrage! Who refused to submit to it?" " Meanwhile Greeley assured all that the platform was "broad enough for all... who seek the true interests of the country ... and at the same time guard and advance the best interests of the Empire State." 4

Henry J. Raymond showed the sincerity of his spirit in his attitude towards the Republican party. His editorials acted as oil upon the waters. "The Republican State Convention which assembled at Syracuse yesterday," said the Times, "performed its work quickly and well... the party enters upon the contest with a new batch of candidates ${ }^{5}$ on a platform which will commend itself to the judgment of Republicans throughout the State."

The Republican papers in the western portion of the

1 New York Times, Sept. 26, 1867.

New York Sun, Sept. 27, I867.

3 New York World. Sept. 27, 1867.

- New York Tribune, Sept. 27, 1867.

- New York Times, Sept. 26, 1867. 
State uniformly agreed that the Syracuse convention had acted wisely in nominating a new slate. ${ }^{1}$ The Commercial Advertiser went so far as to admit that certain of the old Unionist officials, especially those on the canal contracting board, had been corrupt. ${ }^{2}$ In the northern section of the State the Republicans appeared to be well satisfied with the choice of Mr. Hulburd, of St. Lawrence County, as their representative on the ticket. No sign of the criticism of Mr. Hulburd, which appeared in other quarters, was manifest in the press of his home town. "So far as our local interests are concerned," said the Daily Journal, of Ogdensburg,

we believe that the Northern portion of the State will be benefited by the nomination and election of Mr. Hulburd. With Mr. Hulburd in the Comptroller's office, we are certain that the influence of at least one of the departments will not be used to prevent the Niagara Ship Canal from becoming a successful enterprise. ${ }^{3}$

The Republican organs of Syracuse seemed to be chiefly impressed with the harmony and good-will displayed in the convention. ${ }^{4}$

Nevertheless, flaws were discovered in the harmony which the western and Syracuse papers vaunted. The Utica Morning Herald, the mouthpeice of Conkling, denied that the new slate had resulted from a movement to increase the power of Fenton by placing him in the vicepresidency the next year. Roberts insisted that the new

1 Buffalo Commercial Adicrtiser. Sept. 26, 27, 1867; Buffalo Express, Sept. 27, 1867; Rochester Daily Democrat. Sept. 26, I867.

${ }^{2}$ Buffalo Commercial Adzcrtiscr, Sept. 27, I867.

3 Ogdensburg Daily Journal, Sept. 27, I867. Sce note supra, p. I67.

4 Syracuse Daily' Journal. Sept. 26, 1867; Syracuse Daily Standard, Sept. 26, 1867 . 
ticket had for its purpose the purification of the party. ${ }^{1}$ This was also the attitude assumed by the Albany Evoninu Journal, which emphasized the endorsement of impartial suffrage. ${ }^{2}$

The Democratic organs of the State considered the nomination of an entire new ticket as an open confession of guilt, a point which they were not slow to urge. ${ }^{3}$ The sentiment seemed to prevail among the Democrats that Fenton had controlled the convention. ${ }^{*}$ But there was one notable exception to this opinion. The Daily Union and Advertıser, of Rochester, viewed the failure to nominate the old ticket not as any condemnation of official corruption but simply as the victory of one "Ring" in the Republican party over another in the struggle for spoils."

Albany was the scene of two co-temporary conventions. The State Temperance Convention met there on the same day, Thursday, October 3rd, with the State Convention of the Democrats. The Temperance convention drew up the usual resolutions and nominated candidates. It attempted, moreover, to exert an influence upon the considerations of the Democratic body, through the proximity of the meeting.

At the Democratic convention the attendance was small, the hall being less than two-thirds full at both of the sessions. In accordance with a custom honored since the days of the Regency, ${ }^{6}$ or because, as the Herald suggested, " the

${ }^{1}$ Utica Morning Herald, Sept. 26, 1867.

- Albany Ez'ening Journal, Sept. 26, 1867.

- Syracuse Daily Courier and Union, Sept. 26, I867; Buffalo Daily Courier, Sept. 27, 1867; Utica Daily Observer, Sept. 26, 1867.

- Buffalo Daily Courier, Sept. 27, 1867.

${ }^{5}$ Rochester Daily Union and Advertiser, Sept. 24, I867.

${ }^{6}$ A group of Democratic politicians, who two decades before the Civil War, controlled the politics of the State. 
managers of the convention ... were determined not to hazard the success of their party by leaving anything to be settled in the public deliberations of the delegates," 1 the convention adjourned on the first day without taking action on nominations or platform. Samuel J. Tilden, Ex-Governor Seymour, and Mayor Hoffman, of New York, were the prominent figures of the convention.

The World stated that the Democratic State convention had not assembled for many years " under circumstances so auspicious to harmony, energy, courage, and hope; nor has there ever been a time in the whole history of the country when consequences so important depended on Democratic success." " Samuel J. Tilden, in his speech calling the convention to order, congratulated the delegates upon the harmony everywhere apparent. He hoped that nothing would be recalled save the public good and that all personal preferences and predilections would be ignored, looking towards harmony in the Presidential contest of the ensuing year. A brief but mighty struggle took place between Hoffman and Horatio Seymour, as to who should be permanent chairman. Hoffman's friends coveted the honor for him in the belief that its prestige would strengthen him in his candidacy for Governor in the next convention. It was seen, nevertheless, that Seymour was still far too powerful, so a hasty retreat was effected. Hoffman was made the temporary chairman instead. His speech was well received, but failed to create much enthusiasm among the country delegates, who were not fully appreciative of his slang and frequent reference to the negro. He gave evidence of the location of his support in a violent denunciation of the recent legislation affecting the

1 New York Herald, Oct. 5, I867.

${ }^{2}$ New York World, Oct. 2, I867. 
metropolitan administration and the enforcement of the excise law. He ridiculed the so-called "Lager Beer Resolution " of the Republican convention. He sprang a surprise upon a certain portion of the Democrats by taking a decided stand for the payment of every dollar of the $\mathrm{Na}$ tional debt in accordance with the letter and spirit of the bond. However, this statement was not without the non sequitur that the above could be accomplished only by restoring the Democracy to power.

Horatio Seymour, upon accepting the chairmanship of the convention, received a sincerely enthusiastic ovation. ${ }^{2}$ He took grounds similar to those expressed by Hoffman on the financial situation, which occupied the chief portion of his address. Our credit must be preserved, the Republicans have failed, Democracy alone can do it, was the tenor of his remarks. He declared that the Republicans were crying out that the country was in danger and that the Democracy could not escape from the problems before the country. After referring to the corruption in the Republican ranks, Seymour turned to the inequalities of representation in the Senate. For an example he balanced Colorado which, as he said, could not uphold the rudiments of a State government, against New York State with a population of 4,000,000. ${ }^{3}$ Like Hoffman, he aimed for the German vote in urging tolerance for a people whose social customs differed from our own.

'The Herald admired Mr. Seymour's speech as a "vigor-

1 The World spread broadcast the fact that the Temperance League had placed documents in the seat of every member of the convention, declaring that they would support for office none but avowed temperance men. New York World, Sept. 26, I867.

- New York Herald. Oct. 5, I867.

3 New York Times, Oct. 4, I867. Seymour either must have aimed at confusing his hearers, or must have been hard pressed for a comparison, as Colorado was not mare a State until August I, 1876. 
ous, clear, statesmanlike view of the condition of the country ", but added, " he is not out of the woods yet". "In the latter vein the Evoning Post remarked that some parts of Seymour's speech "had a sound of I86I in them, as though the speaker had just waked from a long sleep." ${ }_{2}$ As usual, Horace Greeley did not stop to select his words in speaking of his ancient antagonist. "Mr. Seymour is a very oily speaker, who needs only integrity and wisdom to make him a very honest and able man. Without those qualities he remains a demagogue whose utterances . . . he has neither the discretion to conceal nor the courage to carry out." 3 Harper's Weckly took the occasion to review Seymour's political past, in an indictment which would have made a man of smaller calibre than Seymour quail. ${ }^{4}$

${ }^{1}$ New York Herald, Oct. 4, 1867.

- New York Evening Post, Oct. 5, 1867.

3 New York Tribune, Oct. 5, I867.

"Harper's Weekly, Oct. I9, 1867, p. 659. "Horatio Seymour was the spokesman of the party in the convention as he has been its chief for some years. He was the chosen representative of the spirit of 'reaction' which is to undo the work of the war. And who is this representative? It is the same Horatio Seymour who, in December, I86o, at the notorious Tweedle Hall Convention, tried to defeat the Government in advance and secure the triumph of Rebellion. It is the same Horatio Seymour who declared that if it came to a choice between the Union and slavery, he was for le ting the Union go and saving slavery. It is the same Horatio Seymour whom the Rebellion made Governor in 1862 and who appointed John A. Green, known only as one of the most malignant of Copperheads, military commander of a large part of the State, for what purpose it is not difficult to imagine. It is the same Horatio Seymour who, in the New York Academy of Music on July 4. 1863, when Lee was pressing into Pennsylvania, taunted the Government with its failure, asked contemptuously for the 'great victories' that had been promised and warned it that the mob could be lawless as well as the Government. ... It is the same Horatio Seymour who, when the mob of New York obeyed the word he had given them and ravaged the city, stood before them at the City Hall and calling them, still flushed and 
The opening speeches of the convention were further rounded out by A. Oakey Hall, of Tammany fame, who in response to numerous calls made a short address which appealed to the humor of the convention. Among other remarks he said that the Democrats " had met to prepare so far as the State of New York was concerned, the obsequies of the Radical party, which was about to die of 'yellow mulatto fever', it having now the 'black vomit', the last stage of the disease." 1

The various delegations were in practical unanimity. Although the members of the Mozart $\mathrm{Hall}^{2}$ delegation were ignored in their official capacity, they made no resistance. Tammany rewarded their good behavior by an invitation to seats as honorary guests of the convention. An amendment to the motion which seated the Mozart delegation, also honored another delegation representing the German lager-beer interests. ${ }^{3}$ The first day of the convention was occupied with organization and speeches. Consiclerable caucusing was carried on among the up-State delegates, for the Tammany delegates had suddenly outgrown their

reeking with the wanton and barbarous massacre of helpless men, women and children, 'my friends,' promised them that the laws should be executed, but that he would try to have them changed as his 'friends' desired. And, finally, it is the same Horatio Seymour who presided over the last National Convention of the Democratic Party which joyfully declared the war a failure and stimulated the expiring rebellion to one more struggle."

1 New York Times, Oct. 4, I867.

'It appears that the Mozart Hall men cared comparatively little what the composition of the State ticket or the principles of the party platform might be, so long as they could make a profitable arrangement in the mat er of the coming charter election. The Mozart and Tammany Halls difficulty, which threatened at one time to result in an airing of the "dirty clothes" of the respective factions, was adjusted in less than five minutes. New York Herald, Oct. 4, I867.

s New York Herald, Oct. 4, i867. 
avariciousness and appetite for office. At least, they came to the convention generously offering no candidates, or perhaps better still, urging no candidates. Uncharitable persons were prone to remark, that as there were no offices worthy of notice at this time, Tammany was asking for nothing, in anticipation of asking for all, the following year on the strength of their previous generosity.

Horatio Seymour ruled the convention. The new State committee was framed in his interests. Even so, the remarkable harmony displayed in the convention received a rude jolt when the platform came up for consideration. After having heard the report of Mr. John B. Haskin, of Westchester, chairman of the committee on resolutions, Mr. John McKeon startled the convention with a most vehement protest against the entire platform. He believed it was time for the Democratic party to come out in the open, to take a bold stand and to dare proclaim the real sentiments of the party. "They have stood on the defensive long enough and it was time they made an attack upon the enemy." 1 Mr. McKeon ended his remarks with a denunciation of the whole platform as meaningless and offered an amendment to the fifth resolution. which pledged the convention to repeal the excise law of April, i866. This was passed without much opposition. He further desired the party to state distinctly in the resolution touching the national debt that the bonds were payable in currency. Mr. E. A. Lawrence offered an amendment to the effect that the bonds ought to be taxed. This brought Mr. Haskin to his feet in defense of the resolutions. He asserted that the amendments in question practically amounted to a repudiation of the national obligations. The obstreperous faction was at once put down by a formal ballot. on Mr. 
Lawrence's motion, of ro3 to I8. ${ }^{1}$ McKeon, seeing the hopelessness of his case, permitted the other resolutions to pass unobstructed. His action in denouncing the "craven heartedness" of the managers and his prophecy that their ticket would be beaten by a majority of 20,000 , was characterized by Harper's Weekly as " the only striking point in the whole proceedings," " while the Sun looked on the McKeon resolutions as "a jumble of State-rights doctrine mingled with a little Declaration of Independence and considerable Andrew Jackson." 3

After the usual amendment and discussion, the platform was adopted with a pledge " to redeem New York from corruption and misrule." ${ }_{4}$ It regarded the national debt as a sacred obligation. As was to be expected, the Republican party was denounced for its reconstruction policy. Article IV was a stinging arraignment of the Republicans. setting forth

the revelations of corruption in the management of the canals, the confessed degradation of the Legislature, the resort to extraordinary commissions to control municipalities, the demoralization of the revenue service, and the fact that a party holding power over Congress, the Judiciary, the Executive and the Army has failed to bring peace, solidity and credit to the country. ${ }^{5}$

The obvious remedy was the return of the Democracy to power. The platform assailed the existing excise law, in urging that any excise law "which under the pretext of moral reform, invades private rights, subjects citizens to vexatious searches and seizures and interferes with social

${ }^{1}$ New York Herald, Oct. 5, 1867.

'Harper's Weekly. Oct. I9, I867, p. 659.

- New York Sun. Oct. 4, I867.

- New York Herald, Oct. 5, 1867.

s/bid. 
and religious customs," " was subversive of the true ideals of American citizenship. ${ }^{2}$ The decision of Secretary of State William L. Macy in the Koszta case ${ }^{3}$ was upheld in the platform, which declared for the protection of adopted. as well as native, citizens in foreign countries. And, lastly, not to be outclone in gallantry by the Republicans, an expression of thanks 'was extended to the soldiers and sailors for their aid to the Union.

The strife over nominations was far from keen. The caucus of candidates was left entirely to the up-State delegates. A slate made out the day previous to the first meeting of the convention contained but few alterations in its final form. The chief contest came over the office of secretary of state. ${ }^{4}$ Mr. John A. Greene, of Onondaga, was nominated, but declined the nomination, thus centering the fight between D. R. FloydJones and Homer A. Nelson, of Dutchess. Considerable Coubt was thrown upon the feasibility of Mr. Nelson's candidacy because of his attitude upon the Fourteenth Amendment. Mr. John McKeon asked if Mr. Nelson had not voted affirmatively for the amendment in Congress, and when answered affirmatively, said that Nelson "would be defeated by io,ooo majority". "Mr. Lanning. who had nomi-

${ }^{1}$ New York Herald, Oct. 5, 1867.

- Sec Nation, Oct., I867. The Nation facetiously suggested that the "Convention evidently supposed that drinking lager beer was some "sacred religious rite' which the intolerance of the law had prohibited." It declared this to be a mistake, that drinking either whiskey or beer is a purely secular performance.

- Scott's, Cases on International Laze, pp. foo-I ; Cf., also. Magoon's, Military Occupation, pp. IIS-I20; for the correspondence 2 W'harton's Digest, 175, I98. Nartin Koszta, a native of Hungary, had made his declaration of intention and was domiciled in the United States.

4 New York IVorld, Oct. 5, i867.

${ }^{5}$ New York Times, Oct. 5, 1867. 
nated Nelson, replied that he did right in voting for the amendment and "would be elected by twice ro,ooo majority ". ${ }^{1}$ The vote resulted in Nelson receiving 67 votes to 53 for Floyd-Jones. " The only other office for which the nominations came to vote was that of state treasurer. Mr. Wheeler H. Bristol, of Tioga, with 43 votes, received the nomination over General Jacob $\mathrm{H}$. Hardenburgh, of [lster, with It." The other nominations were made by acclamation." Several nominees "were offered for the Court of Appeals, but all withdrew in favor of Martin Grover.

That the convention was not rushed through was the subject of congratulations to Democrats at the hands of the

${ }^{1}$ New York Times, Oct. 5, i867.

- Other votes were: William McMurray-II; George B. Scott-2.

${ }^{3}$ Scattering: Darius Clark-2; Samuel Worth-I.

"New York World, Oct. 5, I867.

The Democratic ticket was:

Secretary of State-Homer A. Nelson, of Dutchess.

Comptroller-Judge Wm. F. Allen, of Oswego.

Treasurer-Wheeler H. Bristol, of Tioga.

Attorney-General-Marshall B. Champlain, of Allegany.

Canal Commissioner-John D. Fay, of Monroe.

State Engineer and Surveyor--Van Rensselaer Richmond, of Wayne. Inspector of State Prisons-Nicholas B. Scheu, of Erie.

Judge of Court of Appeals--Martin Grover, of Allegany.

New York WVorld, Oct. $5,1867$.

The State Committee was:

Ist Judicial District-Peter B. Sweeny and Charles G. Cornell.

and Judicial District-Erastus Ide and W. A. Fowler.

3rd Judicial District-Peter Cagger and Isaac McCoombs, Jr.

4il Judicial District-Isaiah Blood and Mloore R. Knapp.

5th Judicial District-John A. Greene. Jr. and George H. Sanford.

6th Judicial District-Stephen T. Arnot and N. Wilson Parker.

7th Judicial District--E. P. Ross and C. C. B. Walker.

8th Judicial District-Henry A. Richmond and James Jackson, Jr.

At Large-Samuel J. Tilden, Samuel North and William G. Fargo.

5.Mr. Ganson. Daniel Pratt, of Onondaga. and George F. Comstock, of Onondaga. 
World. "The result of the deliberations of this convention are such as no Democrat need be ashamed ". ${ }^{\text {. Aside }}$ from the excise and suffrage planks, the most vulnerable spots in the Radical platform, the Sun ${ }^{2}$ considered the platforn to be mlade up of "filling in" material. The idea seemed to prevail that the Democratic convention had adopted the adage that it is better to say too little than too much. The various Republican organs in New York City were differently keyed in their treatment of the Democratic convention. The Commercial Adacrtiscr, consistent in its feud with Greeley, gave a cautious approval to the work of the convention.

The Democrats have acted-if not with all the wisdom of their better days-with a returning sense of what belongs to a good Government. Their candidates are personally unexceptionable. [The platform] if it does not strengthen, certainly will not weaken their ticket. . . It is not wise . . as the Tribune does, to underrate the strength of, or sneer at the Democratic ticket.

The attitude of the Tribune may be aptly illustrated by freeley's erlitorial on silence.

${ }^{1}$ New York IIorld, Oct. 11, I867.

The points of the Democratic candidates were summarized by the II orld:

Nelson-age 39 years, lawyer, County Judge, Congress, Colonel I 59 N. Y. Vols.

Allen-age 5o years, Legislature, Judge of Supreme Court.

Bristol-engineer, wealthy, never had held an elective office.

Champlain-Legislature, Nember Constitutional Convention.

Richmond-Had held same office I857-9.

Fay-Active canal man, never had held an elective office.

Scheu-German Brewer of Buffalo, wealthy.

Grover-Superior legal attainments.

- New York Sun, Oct. 5, 1867.

- New York Commercial Adi'crtiser, Oct. 5, 1867. 
The platform adopted by the Democratic convention in New York is more expressive in its silence than in its language. It is silent on the ancient doctrines of state sovereignty, strict construction of the Constitution, the Virginia and Kentucky ordinance of 1798 , the rights of slavery, and the merits of free trade. It fails to endorse or compliment President Johnson. ... It dares not disapprove the national banking system, or the present tariff, or even to suggest in plain terms how easily the government may support itself by collecting taxes from its creditors on what it owes. ... It forgets that it ever declared the war a failure. It advocates an Excise Law under which there can be no arrests, searches or seizures and obedience to which shall be left to the influence of moral suasion.'

This martial array of unwelcome reminders might weil draw forth the rebuke of the Commercial Advertiscr. Had Greeley but realized it, he must needs cast the beam from his own eye before he could pick out the motes from those of his opponents, as the result of the election testified. The same policy of underestimating the Democratic strength was followed by the Times and Harper's Weekly. The former said of the Democratic platform that it was composed of innocent platitudes and the ticket of respectable nonentities. "They appeal in the former to the prejudices, and in the latter to the ignorance of their party." : Harper's Weekly did not profess to have seen in the Democratic convention a very brilliant sign of "the great reaction"." "The convention showed that the Democratic party is the same party, controlled by the same leaders as for the last ten years ".4

In keeping with the Republican abuse of the Democratic

1 New York Tribune, Oct. 8, 1867.

New York Times, Oct. 5, 1867.

'Harper's Weekly. Oct. I9, 1867, p. 659.

'Ibid. 
convention at the hands of the City papers, the Republican State journals found no good in it, with the exception of the Utica Morning Herald, which admitted that the ticket contained some good names. ${ }^{1}$ Mr. Roberts saw in the Mckeon revolt signs of hope for a reorganized Democracy. ${ }^{2}$ A metaphor conveyed the contempt of the Buffalo Express, which may be taken as typical of the up-State Republican attitude towards Democracy in the early campaign: "Never was there a combination selected for a ballot which bore so distinctly the mildew of defeat upon its swaddling clothes as this." ${ }^{3}$

Contrasted with the slur of the Republican organs on the Albany convention, the up-State Democratic editorial opinions rang true, a statement which is made advisedly. The confidence of the State Democrats was marked. The harmony of the Albany convention could mean but one thing. The reaction in favor of Democracy had begun. ${ }^{4}$ The Rochester Daily Union and Advertiser marveled: "Even

${ }^{1}$ Utica Morning Herald, Oct. 5, 1867.

Ibid.

Buffalo Express, Oct. 7, I867.

"The platform pledges itself to redeem the State from corruption and misrule when its accession to power would only plunge it more deeply into that vortex."

Syracuse Daily Standard, Oct. 5, I867.

"Democracy is at least consistent in not placing upon the ticket a single soldier. They vaporize through Seymour's speech of 'putting down the rebellion,' but they are careful not to provide for a single one of those who really 'put down the rebellion,' by nominating him for office.... Few soldiers would take it... Our heroes and the Democracy are at antipodes." The editor was prone to forget that in the previous election attacks had been made on the Democrats because they were trying to win the election on the popularity of the soldiers.

Rochester Daily Democrat. Oct. 5, I867.

- Syracuse Daily Courier and Union. Oct. 5, 1867; Buffalo Daily Courier, Oct. 5, 1867; Utica Daily Observer, Oct. 5, 1867. 
that annual fire-brand of Democratic state conventions, the contest of seats between Tammany and Mozart Halls, was by mutual consent and without a murmur stifled under the prevalent feeling. . . ." 1

${ }^{1}$ Rochester Daily Union and Advertiser, Oct. 5, I867. 


\section{CHAPTER VIII}

\section{The Democratic Reaction}

The Republicans at the inception of the active campaign of 1867 attempted to throw the burden of proof upon the Democrats, making issue on matters of national importance. But the Democrats were too wary to be coaxed from their snug haven of State issues, the entrance to which was studded with rocks and shoals, dangerous to the New York Republican Ship of State. The Times gave evidence of the line of Republican attack in an editorial dated October 4, I 867 .

Naturally enough, the Democratic State convention seeks to bring State and local issues into the foreground in the pending canvass. The attempt will not succeed. The thing cannot be done. This, on some accounts, is greatly to be regretted, for there are many questions connected with State politics of great importance, which demand prompt and decisive decisions. But, from the necessity of the case they must be postponed. The restoration of the Union is the main question before the country and must so remain until it is finally decided. ${ }^{1}$

The Times, in its attitude of conciliation and loyalty, further maintained that the Congressional plan of recon. struction was the only plan before the country. "It is that or nothing." 2

In conducting the fall campaign, the Tribune repudiated

${ }^{1}$ New York Times, Oct. 4, 1867.

Ibid. 
the Radical resolution on the excise and Sunday laws. ${ }^{1}$ The laxity in the enforcement of these laws increased the activity of the Prohibition party and the various temperance organizations, making the Prohibition movement one to be reckoned with. The constitutionality of the excise act, recently passed, had been unanimously confirmed by the Court of Appeals, in spite of the fact that it had been questioned by certain of New York City's honored judges. ${ }^{2}$

${ }^{1}$ New York Tribune, Oct. 17, I867.

2Harper's II'eckly, Jan. 19, 1867, p. 34, summarized, from the report of the Police Board, the condii ion of the City in respect to the retail liquor trade when the board of excise was organized. "On the first of May, 1866, there were 9.250 places where intoxicating liquors were publicly sold. Of this number only $75+$ pretenderl to have licenses leaving about 8,500 open violators of the existing law. The State law already forbade the sale of liquor on Sunday, but at all of these 9,250 places the law was publicly violated every Sunday. From the sale of licenses there should have been a large revenue, and for some years there had been boards of excise to grant licenses. Yet in 1860 , the city revenue from this source was $\$ 54,580$, which was equal to $\mathrm{I}, 8 \mathrm{I} 9$ licenses at $\$ 30$ each. In 1864 the revenue had dwindled to $\$ 12,450$, equal to the proceeds of only 415 licenses at the same rate. The board under the new law established two classes of licenses, one class of \$250 permitting the sale of strong liquor to be drunk on the premises; and one of $\$ 100$ for the sale of ale and beer only. Of these licenses 5,697 were issued, 3,567 of the first class and 2,098 of the second. The total amount of revenue thus collected was $\$ 1,108,925$. Early in June the Cardozo batteries were in full play upon the board. Eight hunlred and fifty-four suits were entered and as many injunctions granted, of which that illustrious ornament of an elective judiciary issued $704 .$. This cannonade silenced the operation of the excise board about July first, until the highes: judicial decision could be obtained. The advantage of the law to the revenue and the saving to the tax-payers we have already mentioned. Its service to public order may be estimated from the fact that on eight Sundays of May and June in 1865 , under the old system, the arrests of drunken and disorderly persons were 1,078: on eight Sundays of the same months in 1866, under the new system, there were 523 , showing a difference of 555 . But when the Cardozian raid upon the law took effect, the comparative result was as follows. On the thirteen Sundays of July, August and September in 1865, the arrests were 2094 , on the corresponding days of 1866 they were $2125 . "$ 
The fight made by the liquor interests, aided by a corrupt judiciary under the inspiration of William M. Tweed, against the excise and Sunday laws for New York City furnished one of the chief centers of battle in the local election. Greeley made his action in repudiation of the excise movement an occasion for a personal tilt with Raymond, whom he tried to make appear as having gone back on his temperance pledges made in 1854 when running for lieutenant-governor of New York. ${ }^{1}$ It is hard to see what Greeley expected to gain by this attack, other than personal gratification.

The Democrats, in general, counted apon the public dissatisfaction, caused by Republican excesses in office and the absurdities of prominent members of the party, to turn the campaign in their favor: while the Republicans, admitting that there was corruption in their midst, sought to show a greater corruption in the unpatriotic course of the Democratic party. It was on these points that the active campaign was waged. Both sides paused to await the verdict of the early fall elections.

The October elections, held on the 8th in Ohio and Iowa for State officers, and in Pennsylvania for a juclge of the supreme court. as well as members of the legislature, gave warning of the result to follow in New York. Pennsylvania went Democratic by a majority of 922 on the vote for judge of the supreme court. ${ }^{2}$ Ohio, although it selected Rutherford B. Hayes for the governorship over Allen G. Thurman by a majority of less than 3,000 , sent in a Democratic legislature and defeated the negro suffrage amendnent by a vote of over $50,000 .{ }^{3}$ In Iowa, as in all other ${ }^{4}$

1 New York Times, Oct. 5, 1867.

- Tribune Almanac, I868, p. $44 . \quad$ slbid., p. 45.

'Ibid.. pp. 43-72. Cf. also New York papers, Oct. 8-I4, I867. 
of the States holding local elections, the Democrats showed a startling increase in their strength.

At once all Republican papers and leaders throughout the nation attempted an explantion of the phenomenon. ${ }^{1}$ Especially did Greeley and the Republican editors of New York State attempt a solution. Among the general causes given for the weakening in Republican strength were: the mistakes of the Radicals in their attitude toward negro suffrage; Reconstruction; the general reaction in business extending over the whole country due to a return to normal phases of business activity, prices and and life: and the advocacy by the IVestern Democrats of the payment of the five-twenty bonds in greenbacks. Conditions in New York point to negro suffrage and the unsettled status of business as the causes which chiefly affected New York State.

Raymond, with his characteristic independence, cautioned the Republicans to put forth greater prudence in the management of party interests if they wished to retain the State. He could not help but show his wound, though healed.

The leadership of the Republican Party has grown arrogant and reckless.... The most extreme theories of the wildest and most impracticable theorists have been forced upon the party as the basis of its creed: and the oldest, strongest and most devoted and efficient men of the party have been spurned and traduced, with reckless violence, if they failed or faltered in giving their assent. ${ }^{2}$

Mr. Greeley, in commenting upon the election in Pennsylvania. issued a warning to the Republicans of New York.

'See Letters of John Sherman: The Nation, Nov. I4. I867; Rhodes. History of the United States.

'New York Times, Oct. Io, I867. 
It was supposed that anything would be elected that could get on the Republican ticket; so nominations were made that the people would not support; while the Democrats, having little hope of success, nominated three soldiers, who had a good war record, for the best offices, and so gained thousands of votes. We trust the lesson will not be lost on those who control nominations in our state. We can tell them that the legislative jobbers and railroad robbers who are 'fixing things' in several districts to nominate themselves to our next Legislature may buy ever so many delegates, but cannot buy the people. Mr. Jacob Sharp, for example, will waste his money if he uses it to achieve a Republican nomination.

In the same vein the Times warned the Republican managers that several nominations already made, if persisted in, would cost the State ticket a good many votes. The two most conspicuous cases" were those of Senator Williams. of the Cayuga district, who had had a notorious legislative career, and Matt P. Bemis, of Chautauqua, who had been renominated for the assembly. The Albany Evening Journal spoke of the renomination of Senator IVilliams in the Cayuga and Wayne districts as having been perfectly "regular" and as therefore binding on every Republican voter. The convention by which it was made consisted of thirteen delegates, six from Whayne and seven from Cayuga. It is true that the teller of the convention certified that IVilliams had seven votes; but every one of the seven delegates from Cayuga made an affidavit that he had not voted for him. ${ }^{3}$ The Times asked, "Now, if a nomination thus made can be deemed regular... we should like to know what

${ }^{1}$ New York Tribune, Oct. Io, I867.

- Other cases were-Mr. Kimball, of Franklin; Gideon Searle and E. C. Topliff, of Cattaraugus. A portion of the Republicans of Cattaraugus petitioned against nominations of the latter two. New York Er'ening Post, Oct. 23, 1867.

- Albany Evening Journal, Oct., 1867. 
would be deemed irregular." ${ }^{1}$ The Commercial Advertiser asked regarding Mr. Bemis-" Are the Republican electors of Chautauqua so fallen that they desire to be represented in the legislature by a man who was for a long time hiding in Canada to avoid the service of process upon a charge of legislative corruption?" 2

While the Republicans were universally explaining the October defeat, saying that it was but a falling off from the Republican vote rather than an increase in Democratic strength, the Democrats were uniformly rejoiced. The Democrats of New York seemed to feel victory in the air. In ever-ready political indicator. Fernando IVood, the first boss of Tammany, ${ }^{3}$ at once openly made his plans to place himself as the next mayor of New York. He complacently laid down his platform, and gave his nomination to the most faithful of his henchmen.

On the evening of October I6, I867, a large, enthusiastic Republican rally was held in Cooper Union to ratify the Republican nominations. The sentiment of the meeting was easily revealed by the mottoes pendent from the ceiling. Chief among them were: "Andrew JohnsonTraitor, Renegade, Outcast": "Our Statesmen-Fenton. Conkling, Morgan, Van Wyck, Tremaine, Hutchins".

1 New York Times. Oct. 31, I867.

'New York Commcrcial Adz'crtiscr, Oct. 2, I867. Bemis came from Fenton's district. The Commercial Adiertiser positively remarks"Pemis claims to be the especial friend of Governor Fenton, in whose name he negotiates for the Governor's autograph to bills, and for whom, as he claimed, he obtained money last winter at Albany from the Central Railroad. We do not say that this was done for Governor Fenton or with his knowledge. Bemis either told the truth or obtained money under false pretences. This, at any rate, is time to test the question If it is true, then it is easy to see why the Governor wants Bemis in the legislature. If false, decent considerations of self-respect will induce him to veto that nomination."

' Gustavus Myers, History of Tammany Hall, passim. 
Prominent among those present were Ex-Governor Morgan, Horace Greeley, Chauncey M. Depew, John A. Kennedy, William M. Evarts, Charles S. Spencer, John Cochrane and Peter Cooper. Horace Greeley's hold on the party at this time was in a small way indicated by the hurricane of applause with which he was greeted when he read the resolutions of the meeting, the tenor of which was to uphold the worthiness of certain of the Republican candidates for office, while the plank in the convention platform which condemned corruption was strongly approved. ${ }^{1}$ William M. Evarts in addressing the assemblage struck the keynote of the campaign. "The Democrats now seek to restore the 'lost cause'. It is Pendleton and Vallandigham, of Ohio, and Seymour and IVood, of New York, and Pierce, of New Hampshire, trying to restore the trimmph of the beaten rebellion. Shall we allow the Government to pass into the hands of such men?" 2 Ex-Governor Morgan made the chief address of the evening. He referred to the Congressional conditions imposed by Congress on the lately rebellious States as a vital necessity to the country's safety. He maintained that the only true safeguards against civil disorder in the South were impartial manhood suffrage and popular education. The currency should be returned to a firm specie basis and all debts paid. Channcey M. Depew next spoke. "with the wisrlom that surpasseth knowledge," on the question of taxation. State and National. He "counseled Congress to meet every proposition tending to increase taxation, when not demanded by the soundest statesmanship, with emphatic refusal".

1 New York Herald, Oct. 17, I867.

${ }^{2}$ Ibid.

${ }^{3}$ New York Herald. Oct. 17, 1867. On Octoher 23, 1867, Speaker Colfax crowded Cooper Union with Radicals. He argued in favor of Grant and rlemanded Johnson's impeachment. New York Tribune. Oct. 24, 1867. 
It would not be in accord with fact to state that the Democrats gave themselves up entirely to rejoicing as a result of the October indications of a Democratic victory in November. ${ }^{1}$ Both the Sun and the World issued warnings to the Democratic party to beware of excesses. "The tendency of successful parties," reminded the World, " is to forget that society never stands still ... that the policy of a past generation can never exactly tally with the wants of the present." 2 That a similar reaction against the Lnionists in favor of Democracy had swept the country from New York to Illinois in I 862, was pointed out by the Hcrald," but the advantage had been swept away by the blunder of following Copperhead leaders. Doubtless the attitude of caution which the Democracy of New York State assumed after it had become apparent that the tide was setting in its favor had much to do with the November victory. Certain it is that the Democratic press all modeled after the IVorld in emphasizing the futility of counting their victory before it had been won.

The ratification of the Democratic State and local tickets occurred on October 25th. Horatio Seymour. Hon. Henry C. Murphy and Mr. J. G. Martin were the prominent speakers. By placing the charge "upon the Republican party that they have been less patriotic than ourselves," ${ }^{4}$ Mr. Seymour afforded a few of his hearers, at

1 New York Erching Post, Oct. 17, I867. "We have always agreed with the Democrats on the subjects of free trade, the currency, state independence, and local self-government, but it must not be inferred that we are wholly satisfied with them. either in the past or present."

- New York IVorld. Oct. I1, I867: Oct. I8, I867; Oct. 26, I867.

3 New York Herald, Oct. I4, I867.

- New York Times, Oct. 25, 1867; also cf. New York Ei'ening Post, Oct. 25,1867 . 
least, an acrid pleasure. Moreover, he generously ad1nitted, in view of his broad public life and wide experience with men, that had the Democratic party been placed in the same temptation as had the Radicals, the former would have erred just as grievously. That was a good deal from Seymuur. It is not beyond the range of probability that Seymour's knack in skilfully dodging the real issues, as in his convention speech, and his diplonnatic endeavors to assuage the bitter feelings of the war-time, brought the Democrats many votes.

Party managers on both sides kept their weather eye upon the Presidential canvass for the following year. Thus early, the Times predicted that a military hero would perforce be nominated. if the party were not to be overwhelned in defeat. ${ }^{1}$ The feeling was prevalent that had the elections of 1867 gone with the usual Radical flavor almost any man whom the party chose to nominate for President would be easily elected. Perhaps the preference would have gone to Justice Chase. However, the election results. especially in Ohio, demonstrated how great had been the revulsion of feeling away from the principles for which Judge Chase and his colleagues stood. The name of Crant, under the existing circumstances, was in the minds of both Radicals and Democrats as the most available candidate. $^{2}$

1 New York Tines, Oct I7, i867.

"James Ford Rhodes, The History of the United States. The New York Herald, Oct. I4, I867, and the New York Commercial Adrertiser, Nov. 8, 1867, urged Grant's name strongly. The New York Horld, Oct. 12, and I 7 , I86\%, attempted to persuade Grant that he had not the slightest chance of election. New York Tribune, Nov. 8. 1867. Greeley professed to see in Pendleton, of Ohio, Democratic candiclate for vice-presiden in I864, the next Democratic President and apropos of the defeat of negro suffrage in Ohio stated that Vallandigham (noted Copperhead) would be able to beat Grant if the hacks were not enfranchised. 
Mid-campaign found both parties exhibiting general apathy. ${ }^{1}$ In New York City more interest was displayed in the coming charter elections than in those of the State. The orators of the Republicans spent all their powder on the policy of reconstruction without adding anything new, and made people grow weary in disgust. ${ }^{2}$ As events proved, the people cared more about taxation than threats of impeachment. Messrs. Sumner's and Stevens' theories as to Republican government in States had less interest than the Congressional efforts at retrenchment. The various leakages in the national treasury due to fraud had greater charm than legislation fostered in favor of special interests. The question of inflation was a more potent cause for terror than the probabilities of proscriptive legislation at the hands of extremists. These were a few of the more important points wherein the political managers of the Republicans failed to gauge the thoughts of the more intelligent people. That the Times understood this failure on the part of the Republicans is shown by its early preparation for disaster. On October $25^{\text {th }}$ it announced that "the Republican party has an up-hill task in the coming election, but it is making a vigorous and resolute effort for success. The State is very close at best and the October elections in other States always exert a very decided influence on our own." 3

On October 24th a State convention of brewers. hop growers and liquor dealers was held in New York City. So prominent had the excise question become in the campaign that the liquor interests were in grave fear lest the excise law, if not checked. should be the forerunner of Prohibition. Candiclates for the assembly

'New York Sun, Oct. 22, 1867.

' New York Times, Oct. 23, 186;

${ }^{3}$ New York Times, Oct. 25, 1867. 
and senate were nominated and were pledged to work for the appeal on the amendment of the excise law. ${ }^{1}$ Arthur Brown, of Oswego, was elected president of the convention and Richard Katzenmeyer, of New York, secretary. A series of resolutions were drawn up decrying the excise law and with altruistic motive pointing out the way whereby the ethical and physical condition of men could be uplifted by a gradual emancipation from the drink habit. ${ }^{2}$

Another matter which had considerable effect upon the brewers' convention, and a decided effect upon the campaign as a whole, was the discovery by the revenue and treasury officials of large frauds among certain New York distilling firms. ${ }^{3}$ These discoveries were made in connection with investigation into whiskey frauds all over the country, but especially in the East. The brewers were keenly alive to the discredit and suspicion cast upon them by the dishonesty of certain of their number. Moreover, they felt the reflex action because the frauds had occurred during their régime. The Herald, ${ }^{4}$ the Evening Post, ${ }^{5}$ and

1 New York Times, Oct. 25, I867.

- New York Times, Oct. 25. 1867. The appeal made by the convention of brewers to the Argumentum ad hominem is humorous in the extreme..." the most effective way to check intemperance is gradually to detach the people from their old habits of drinking sirong and ardent spirits, by placing within their reach a mild nutritious substitute containing stimulating power, in a less degree. . . Malt liquors, in consequence of their dietetic, nutritious, tonic and other wholesome qualities, their purity and their tendency, when used as a beverage, to gradually create a distaste for strong liquor, have been found to be the most wholesome, but at the same time the cheapest substitute."

'The disclosures in connection with the Bourbon Company of New York City created the greatest outcry. New York Tribunc, Sept. 2I, 1867. New York Herald, Oct. 2I, I867.

4 New York Herald, Oct. 21, 1867.

${ }^{5}$ New York Ei'ening Post, Oct. 8, I867; Nov. 13, 1867. 
the World $^{1}$ gave especial attention to the whiskey fraud disclosures in New York. The Evcning Post did not confine itself to the whiskey frauds but boldly attacked the customs revenue collections in New York City, stating that "the amount of cigars and manufactured tobacco produced in the City of New York and paying no tax is so great as to demand the special attention of the department ". Under the caption "The Way the Government is served", the Nation pointed out that through frauds, waste and the incompetency of employees at the New York custom house, from $\$ 12,000,000$ to $\$ 25,000,000$ was lost to the United States annually. ${ }^{3}$

As a result of the attacks of the Nation and the Evening Post on the custom and revenue officers of the administration, and the constant hostility of the Commercial Advertiscr $^{4}$ towards the Tribunc, Horace Greeley turned his batteries upon these publications, including the Times, in the conservative group. A merry internecine war followed between the two groups of journals representing the Conservative and the Radical factions of the Republicans. While Greeley, as commander of the Radical faction, was leading the cohorts of lesser State journals against such "political wire-workers and hangers on" as the Commercial Advertiser" and the Times and the Nation, who were " filling the air with raven croakings and doleful prognostications"," the Democrats, taking advantage of this

1 New York World, Oct. IO, I867; Oct. 17, I867.

New York Evening Post, Oct. 8, 1867.

- The Nation, vol. i, ii, p. I98, Feb. I5, 1866.

4 New York Commercial Advertiser, Oct. 2, I867; Oct. 22, I867, et al.

${ }^{5}$ New York Commercial Adzertiser, Oct. 2, I867. The Commercial Advertiser was extremely bitter against Greeley for supporting Senator Humphrey, of Wyoming, for re-election, against whom he had previously directed his blows for corruption.

- New York Tribune, Oct. 22, I867. 
brotherly falling-out, exerted every energy to gain votes.

As the campaign wore on, the politics of New York City became extremely complex, not because of any acute conditions in the affairs of the City at the time but rather on account of a glut in political organizations. By the middle of October no less than seven distinct organizations were at work in the City. In several instances several regular candidates were running for the same office, in addition to self-nominated "Independents". The various organizations formed chiefly from intestine dissensions were as follows: the Union Republicans, Radical Republicans, Tammany Hall, Mozart Hall, the McKeon Democracy, the Union Democracy and the Constitutional Union party. The first two represented respectively the Conservative and the Radical factions of the Republican party, Tammany Hall stood for the Democrats, Mozart Hall was the political child of Fernando Wood which had been brought into the world for the purpose of aggrandizing Fernando. ${ }^{1}$ John McKeon, who had broken with Tammany Hall through its failure to divide up patronage among his followers to his satisfaction, had followed Wood's example and had organized a party all his own. The remaining two parties had origin in quarrels with Tammany over spoils. The last three organizations-the McKeon Democracy, the Union Democracy, and the Constitutional Union party-all Democratic -were managed solely for "bargain and sale "; ${ }^{2}$ that is, they threw their influence wherever it would command the highest price. However, it is estimated that their total voting strength would not exceed five thousand. The first

1 Mozart Hall was organized by Fernando Wood in 1858 for the purpose of making Wood a political power in New York City. It nominated him for Nayor in I86I, but he was defeated by a small plurality. After 1866 Mozart Hall put no candidates in the field.

- New York Times, Oct. 27, 186\%. 
four organizations mentioned, viz.: the two wings of the Republicans and the Tammany and Mozart Democrats, possessed considerable strength.

The Union Republicans nominated no candidates except for State senators and assemblymen. Either with premeditation and malice aforethought or by a sublime juggling we find the name of IVilliam M. Tweed as a candidate on both the Union Republican and Tammany tickets. A. Oakey Hall was a candidate for district attorney upon every ticket of Democratic color except the Union Democracy. The name of Albert Cardozo, patron of immigrants, was found upon the entire five of the Democratic tickets for Justice of the Supreme Court. ${ }^{1}$

Much to the chagrin and fear of the Republicans, the venality of the Republican legislature was given a fresh airing. On October 26, I867, State Senator Wolcott J. Humphrey, of Wyoning, was arrested at Warsaw on a warrant issued upon an affidavit made by Hugh B. Willson $^{2}$ which charged him with bribery and corruption in office. It appears that Senator Humphrey during the session of I 867 was a nember of the senate railroad committee, and had declared, so his accuser claimed, that he would hold up certain legislation in the committee unless he was paid five hundred dollars. If the bill passed the senate lie was to receive a further $\$ 2,500$. The deponent claimed that he had been personally told by the accused that the five hundred dollars had been received.

The Citizens' Association of New York took up the charges. The other two members of the "ring" which controlled action in the senate railroad committee were

1 The Times for October 27. 1867, gives a complete and carefully prepared table of the various nominations.

2 For the affidavit of Hugh B. Willson in full see New York Times, Oct. 28, I867. 
Stephen K. Williams and Mr. Sutherland, of Westchester County. Mr. Williams had been publicly accused of having received $\$ 5,000$ for three successive terms-he had been on the same committee for two terms-to report the New York Central Fare Bill. ${ }^{1}$ At the same time it was understood that Mr. Williams would vote against it in the senate, thus deceive his constituency to whom the bill was obnoxious. Mr. Willson's interest in the charges was neither partisan nor pecuniary. He had spent the greater part of two legislative sessions at Albany as the agent and representative of an association of men who sought to obtain a charter for the construction of an underground railroad. Willson claimed that the fact had been demonstrated to his entire satisfaction, that members of both houses of the legislature made offer of their votes both in committees and in the chamber. ${ }^{2}$ The charges resulted as usual in such cases-not proved. Senator Humphrey was renominated by the Republicans of his district. The Buffalo Express defended the nomination and charged that the attack on his character was a "Democratic Plot". 3 In commenting on the renomination of Humphrey by the Republicans, the Herald aimed a direct blow at the probity of the legislature.

It will, however, be immaterial which way the trial may go. ... If Senator Humphrey should be convicted he will only have proved himself the fitter candidate for the State Legislature ... unless it be regarded as a mean job for a Senator to

${ }^{1}$ New York Times, Nov. I, I867. A subsequent correspondent in the Times corrected this staement to the effect that Williams, in 1865, received $\$ 5,000$ to report the bill from the committee. He afterwards was to receive $\$ 5,000$ if it passed the senate. When the bill came before the senate, Williams failed to vote for it and was forced to give back the $\$ 5,000$ under threat of exposure.

New York Times, Oct. 30, 1867.

Buffalo Express. Oct. 26, I867. 
sell himself so low as five hundred dollars, and as improperly depressing the market for Assemblymen and lobbymen.'

The World contributed its share to the exposure of the dark ways of public officers, by using with telling effect against the Republicans the admission of Auditor Benton, president of the State contracting board, that he had received and disbursed thousands under the pretext of erecting a public hall. ${ }^{2}$ Snall comfort was afforded the Republicans by the Times, which decried certain of the Republican nominations as loudly as did the Democratic organs. "If the Republican party will take the responsibility of nominating men who have laid themselves open to such charges, the welfare of the party will be best promoted by their defeat," ${ }^{3}$ reveals the opinion of the Times, which may be taken as representing the best sentiment among the Republican organs. ${ }^{4}$

1 New York Herald, Oct. 28, I867.

New York Horld, Oct I6, I867; Oct. 22, 1867; Oct. 24, 1867, et al.

' New York Times, Oct. 30, I867.

- Harper's Weekly, May 4, 1867, p. 274.

The editorials of Harper's Weekly may be taken as representative of the better class of criticism which was heaped upon the New York legislature because of its corruptness. "The Senate knows that the air is thick with this talk of venality in the Legislature and that it is expected the Constitutional Convention will supply some remedy. Indeed nobody, probably. will deny that the pressure of business upon the Legislature is overwhelming: that the most important bills are rushed through at the last moment... : that the most outrageous jobs are constantly presented in the form of bills and that they are passed or defeated only by the most enormous expenditure of money. These are undeniable fac's. . . How shall it be remedied?... The great remedy is of another kind, for it is moral. A purer public opinion: a refusal to submit to exactions even if refusal be very costly: a relentless exposure of persons and attempts: a willingness of good men to take offices at personal sacrifices: a clear percept on of the national ruin which inevitably follows the mad greed of gold. .... The most cunning Constitutional Convention cannot devise a 
The Republicans throughout the campaign attempted to counteract the Democratic attacks on the corruption among the Republican officers and in the legislature, by charging to the "Ring" controlled by William M. Tweed a multitude of "robberies". ${ }^{1}$ However, the Republicans were compromised in their attempt to make political capital out of Tweed and Tammany Hall, by the fact that Tweed himself was a candidate for State senator on the Union (or Conservative) Republican ticket. Apropos of Tweed's nomination the Tribunc called for the opinion of the Times, the representative of conservatism. The latter replied"We regard the nomination as one 'not fit to be made' . . if Conservative Reptiblicans or any other Republicans can find no better representative than W. M. Tweed, we trust they will be kept out of office permanently." 2

A general awakening to the machinations of the "Tweed Ring ", as controlled under the name of Tammany Hall, was becoming current at this time. ${ }^{3}$ Before any actual disclosures as to the operations of Tammany had been made. the generosity displayed in building a new hall on Fourteenth Street had aroused the suspicions of the people. During the course of its construction the building funds became insufficient. Grand Sachem John Kelly, stated that a loan of $\$ 250,000$ was needed; $\$ 75.000$ had been subscribed immediately, fifteen members alone having sub-

system which will create an honest government out of a dishonest com munity. Every thoughtful individual citizen of the state must set his face sternly and unswervingly against every form of corruption direct or indirect, and then we shall have a beginning of reform. Howling at the Legislature for corruption and then bribing it will not purify that body."

${ }^{1}$ Utica Morning Herald, Oct. 3I, I867. Roberts scored Tweed and the legislative purity unmercifully.

' New York Times, Oct. 30, I867.

'See Myers. The History of Tammany Hall, p. 252. 
scribed $\$$ I0,000 each. ${ }^{1}$ Moreover, what was more astonishing happened when Peter B. Sweeny, the City chanberlain, gave to the City for the benefit of taxpayers over $\$ 200,000$ in fees and interest money which were his lawfully. ${ }^{2}$ Harper's Weckly was the first organ of note to direct thus early an unceasing fire on the "throttling iron ring " 3 which held New York City at its mercy."

In viewing the campaign through the eyes of the State journals one is impressed with the conservatism of the Republican editors. The leading Republican organs of the State constantly warned their party that victory could not be earned by stirring up the past record of Democracy, but only by constructive efforts. The volume of Republican editorial warning increased after the results of the October elections became known. ${ }^{\overline{2}}$ At the same time the Republican State editors pretended to consider the October reverses as indicative of poor Republican organization, nothing more. ${ }^{6}$

The Republican State editors, however, were not conservative to the extent that President Johnson or his policy escaped severe censure. ${ }^{7}$ Neither did they fail to direct

1 Myers, op. cit., p. 257 ; Cf. New York Herald, Sept. 10, I867.

'Myers, op. cit., p. 257.

'Harper's Weekly, Jan. 5, 1867, p. 2, May 5, 1867, p. 274.

- The gigantic frauds perpetrated on the people of New York State were not definitely exposed until 1871 .

- Buffalo Express, Oct. II, I867: Rochester Daily Democrat, Oct. 7, 1867; Utica Morning Herald, Oct. 10, 14, I867; Broome H'eekly Republican, Oct. 2, 1867.

- Syracuse Daily Journal, Oct. II, 1867. The Buffalo Daily Courier, Oct. I9, I867, (Dem.) saw in the October elections "disgust at the fruits and fear of the results of Radical rule." Liquor laws, local quarrels, unpopular candidates or apathy were not the cause.

"Buffalo Commercial Adzertiser, Oct. 2, 1867; Rochester Daily Denocrat, Oct. 26, 28, I867. The Syracuse Daily Journal, Oct. 14, 1867 , however, repented of its support of the Radical Congress during the mid-campaign. It considered that Congress was neglecting the national interests of the country in the interest of strengthening the Radical parly at the expense of the South. 
attacks against the Democratic stand for greenbacks and equal taxation, nor against payment of the debt. ${ }^{1}$ Further the matter of the Fourteenth Amendment was constantly urged, especially in connection with the discussion of the Constitutional Convention of 1867 , which had adjourned over the election. ${ }^{2}$

The opposition organs of the State fought over the action of the Constitutional Convention in taking an adjournment more uniformly than those of the City. The Republican organs maintained that, even if it were illegal for the convention to adjourn. the legislature would legitimatize its acts upon reconvening. ${ }^{3}$ On the other hand, the Democratic papers assumed that the convention was legally dead and made all manner of ridicule over its preference to die rather than to swallow its own medicine-negro suffrage. ${ }^{4}$

It was in the matter of Republican corruption, nevertheless, that the Democratic State journals found their adversaries weakest spot. The Republicans denied as best they could that corruption and dissensions had lodged in their midst," but the Denocrats would not be silenced. It was disclosed that an organized revolt had occurred in the Republican ranks of Yates County under the leadership of the Penn Yan Chronicle. ${ }^{6}$ In Genesee County great dissatisfaction had occurred among the Republicans over the overthrow of Judge Taggart by the county committee. 2 The arrest of Senator Humphrey, the Republican candidate, has

${ }^{1}$ Utica Morning Herald, Oct. 23, 1867; Buffalo Commercial Advertiser, Oct. 7, 1867.

2 Vide infra, ch. ix.

- Syracuse Daily Journal, September 28, I867; Broome Weekly Republican, Sept. 25, I867.

- Utica Daily Obserier, Sept. 25, 1867; Buffalo Daily Courier, Sept. 26, I 867 .

- Rochester Daily Democrat, Oct. Io, 26, 28, 30 ; Nov. 4, I867.

${ }^{6}$ See Penn Yan Chronicle, Sept. 27, 28, 29, 1867; Oct. 6, 8, I0, 1867.

'Rochester Daily Union and Advertiscr, Oct. I2, 1867. 
already been referred to. ${ }^{1}$ In Chautauqua County, Hon. D. H.Waite had severed his connection with the Chautauqua Democrat, a Republican organ. ${ }^{2}$ Mr. Waite had bitterly denounced the nominating convention which had nominated, and was controlled by, such "Rottens" ${ }^{3}$ as Messrs. Williams, Sessions and Bemis. Further Republican dissolution had occurred in Monroe, Cayuga and Seneca counties. ${ }^{4}$ Practically all of the up-State Republican organs preferred to go no further with the charges of corruption lodged against them than a plain denial. The Daily Democrat was an exception to the rule. It devoted considerable energy to the defense of Senator Humphrey, and of John M. Hammond, the Republican candidate for canal commissioner who had been accused of wrong doing in connection with the canal board in $1855^{\circ}$ The Democratic journals of the State took great delight in reviewing old editorials of staunch Republican papers, such as the Albany Eq'cning Journal. The Syracuse Couricr and Union proved a veritable thorn in the flesh of the Evening Journal. During the previous spring the Evoning Journal had exhibited great disgust with the venality of the Republican legislature at Albany, which was then in the throes of the Erie Railroad war. The Evening Journal had also predicted the downfall of Thaddeus Stevens ${ }^{7}$ and had severely criticised the tinkering with the New York City municipal laws. ${ }^{8}$

${ }^{1}$ Rochester Daily Union and Adz'crtiser, Oct. 12, 1867, supra, p. 197.

- Chautauqua Democrat, Oct. I, 2, 3, 1867.

"The term "Rottens" was used to designate corrupt candidates.

- Rochester Daily Union and Advertiser, Oct. 12, 22, 26, 1867.

s Rochester Daily Democrat, Oct. 26, 28, 30, 1867.

'Ibid., Oct. 21, 1867. The Daily Democrat cleared Mr. Hammond to its complete satisfaction, which appeared in keeping with the report of the former investigating committee.

${ }^{\top}$ Albany Evening Journal, Apr. 29, I867.

${ }^{8}$ Albany Ez'ening Journal, quoted Syracuse Daily Courier and Union. May 15,1867 . 
The excise movement was especially fostered under the benign influence of the Tribune. On October 29th, a mammoth meeting was held at Cooper Union, where the Rev. Dr. Newman Hall, a famous London divine visiting in this country, gave the chief address. Greeley also spoke. He incisively attacked the liquor dealers' position, showing that the excise act was not a new law, as Sunday liquor selling had long been enacted against, but that the law had been ignored. "The opponents of the law," said Greeley,

do not desire to repeal : they only want tolerated lawlessness, and with that they would be satisfied. They cry out against the State Police, because that body faithfully enforces a State Law. Give us Wood or Hoffman with a city Police and the law would become a dead letter and the liquor interests would be happy.'

The weak position taken by Mr. Schenck, chairman of the Radical Congressional committee, in his address to the States having November elections, added to the Republicans' embarrassment. He appealed for Republican victories as the only means of preventing a renewal of armed rebellion. He feared that unless the November elections went Republican, President Johnson would disperse Congress by force or resort to violence in some form. He was right in his statement that people demanded the prompt completion of the work of Reconstruction. But he would have been of much greater power in the approaching elections if, instead of exciting passions, he had sought to allay some of the apprehension that justly disturbed the public mind regarding the failure of Radical Reconstruction to work according to plan. $^{2}$

\footnotetext{
${ }^{1}$ New York Tribune, Oct. 30, 1367.

- New York Times, Oct. 31, I867.
} 
The Democrats held their last grand rally on October 3I, I867, at Cooper Union. It was in reality their first united meeting. Mr. James T. Brady, as chairman of the meeting, voiced its sentiments when he referred to the present leaders of the Radical party with such little pleasantries as that "miserable dirty dog Sumner and the superannuated old fool Stevens ". ${ }^{1}$ Charles S. Thayer emphasized the necessity of winning New York City, if the Democratic party would win the State. Outside timber was imported in the shape of Mr. Voorhees, of Indiana, and Montgomery Blair. Both discussed the issues from a national viewpoint. Samuel S. Cox provoked storms of laughter and applause with his mythical illustrations ${ }^{2}$ of God shaking the Republicans over Hell, their safety depending either on the sincerity of their repentance or the strength of their breeches.

That the Republicans were not alone in their family troubles was made apparent through the Democratic papers outside the State. These were less reserved than the local organs, whose silence was significant. The schism which existed within the Democratic ranks was as real as that within the lines of their opponents, and it caused constant jealousies, lukewarmness, and a widespread disgust. A writer to the Charleston Courier said that

honest Democrats, disgusted with the men put in nomination in this section " of the State, will either abstain from voting or support the Radical ticket. . . The politicians can manage the people a good deal, but there are always in an intellectual community like New York, enough respectable voters left who will not do the bidding of the party, when it compels them to vote for prize-fighters, gamblers or rum-sellers. . .

1 New York Times, Nov. I, 1867.

Ibid.

- South-eastern.

- Charleston Courier. Quoted in New York Times, Nov I, 1867. 
Just prior to the close of the campaign, Homer A. Nelson, Democratic candidate for secretary of state, made a final bid for the temperance vote of the State in a letter to E. C. Delavan. In part it read: "I have to say that I sympathize warmly with the temperance reformers. I believe drunkenness to be the bane of the working classes. . . . But I cannot violate a principle, and do not think it right because some persons abuse a benefit, that others should be deprived of it." ${ }^{1}$ The Democrats also kept before the public mind to the end the failure of the Constitutional Convention, which had met in 1867 under Republican control, to come to a vote on the question of negro suffrage before adjournment. ${ }^{2}$ This act of apparent cowardice or of low political strategy proved a great source of weakness to the Republicans in the campaign. The Democrats universally urged that the Republicans of New York were afraid to take their own medicine.

As its last contribution to the campaign, the IVorld reviewed the canal frauds under the Republican administration. ${ }^{3}$ The Vorld, further, attempted to awaken an interest in and make political capital out of the relation of the State banking system to the national system under the new law. It attempted to show how the State was the loser. However, the question failed to arouse much interest, being more a subject of national politics and of Supreme Court decisions. ${ }^{4}$

Massachusetts, Maryland, Minnesota, Wisconsin, with New York, held elections for State officers and legisla-

${ }^{1}$ Quoted in New York World, Oct. 30, 1867.

- The ensuing chapter will discuss the Constitutional Convention of 1867 in detail.

- New York World, Nov, 2, 1867.

- New York World, Oct. 29, 1867; Nov. 5, 1867. Cf. the Report of the State Commission of Banks. New York for 1867. 
tures. New Jersey and Kansas chose State legislatures, while in Michigan, Illinois, Missouri and Nevada, elections were held for county officers. The interest felt throughout the country over the November elections, especially those of New York, was intense. As usual, both parties claimed to be confident of carrying the State by decided majorities, but the boast of the Republicans lacked the ring of belief. True, Governor Fenton's vote of the previous year had carried with it a $13.789^{1}$ majority, but that, out of an aggregate vote of 720000 , was rather a small margin for sure calculation. This was especially true considering the drift of political favor from the Republicans. The Times consoled itself by " believing that whatever the result may be, it cannot have any disastrous effect upon the country. It cannot prevent the success of the Republican party at the presidential election next year." 2

It was due to no fault of the weather, that old standby of Republicans, that they did not win. The day was perfect. Apparently in this case it took more than the weather to bring out both parties. The falling off in numbers could be explained only by the lack of any popular State issue. The Republicans maintained, or affected to maintain, that from a political viewpoint the State offices to be filled were not of the highest importance. There were neither Congressional elections nor a legislature to be elected which would choose a Senator. Why the Republicans should have claimed that the election had neither an intimate nor a remote bearing upon national politics, is one of those questions ever so gigantic because so simple. The result was a complete landslide for the Democrats. Nelson, for secretary of state with a majority of 47,930 votes out of a total of

1 Tribune Almanac, I867, p. $5 \mathrm{I}$.

'New York Times, Nov. 5, I867. 
698,128 cast, ${ }^{1}$ was second in the rumning to John D. Fay, the Democratic candidate for canal commissioner. who had a majority of 50,277. Thomas Hillhouse, for comptroller. led his associates upon the Republican ticket with a total of $325.658 .^{2}$

Although a number of arrests for illegal voting and rioting occurred, the election in New York City, in general, was very quiet. The crowds around the newspaper offices were immense but good humor prevailed, the general opinion being that the result was a foregone conclusion. The Democrats, in addition to carrying every State office, practically made a clean sweep in New York City. One Republican ${ }^{3}$ and an Independent ${ }^{4}$ were sent to the assembly from New York City. The chief point of interest in the local

1 Tribune Almanac, I868, p. 49.

2 Ibid.

The results follow:

Republican.

Secretary of State ......... James B. McKean ......325,099

Comptroller ............. Thomas Hillhouse ......325,658

Treasurer ............... Theodore B. Gates ......325,201

Attorney-General........... Joshua M. Van Cott ....325,328

State Engineer ............ Archibald C. Powell ....324,775

Canal Commissioner......... John M. Hammond .....322,509

Prison Inspector ............Gilbert De La Matyr ...325,018

Judge of the Court of Appeals. Charles Mason ........324,477

Democrat.

Dem.

Maj.

Secretary of State .........Homer A. Nelson .....373,0:9

Comptroller .............William F. Allen.......372,517

Treasurer ...............Wheeler H. Bristol.....372,769

Attorney-General .......... Marshall B. Chamberlain. 372,648

State Engineer ........... Van Rens. Richmond...364,702

Canal Commissioner........ John D. Fay .........372,786

Prison Inspector .......... Solomon Scheu........372,828

Judge of the Court of Appeals. Martin Grover ........364,849

${ }^{3}$ George B. Van Brunt-2oth District.

'James Irving-I6th District. 
election appeared to center around the enforcement of the excise law. ${ }^{\circ}$

The Tribune blamed the New York Republican papers for a large part in the default of voters at the polls. Greeley claimed that they had influenced the State vote to the extent of 50.000. ${ }^{2}$ He also laid a large share of the fault at the door of the canal frauds and peculations during the past three years. The corrupt politicians who had by hook or crook managed to have themselves nominated upon the Republican ticket came in for their share of blame.

We are beaten by the Republicans this year and the work of reconstruction is thus practically delayed, if not arrested. The Southern rebels are virtually told by the State of New York "Hold on! vote against Conventions wherever you are strong enough to defeat then ; refuse to vote wherever you can thus hope to discredit and damage the process more than by voting, and you may again resume control of your respective States, and trample the white and black Unionists under your feet through the disfranchisement and virtual re-enslavement of the latter.",

The explanations of the Republican State organs as to the cause of the Republican defeat were many. Several minor causes were cited but the underlying sentiment seemed to be a distrust of and disgust with Stevens and Sumner." The Syracuse Daily Journal placed the "humiliation of the Republicans " to the credit of Horace Greeley." The feeble administration of the national

${ }^{1}$ New York Times, Nov. 6, I867.

' Before the election, Greeley said that an omnibus would hold all of the votes that the said journals could control.

s New York Tribune, Nov. 6, I867.

'Buffalo Commercial Adzertiser, Nov. 7, i867; Ogdensburg Daily Journal, Nov, 6, r867.

- Syracuse Daily Journal, Nov. 7, 1867. 
finances, the increased debt and a failure to meet the negro suffrage issue were given as the causes by the Buffalo Express. ${ }^{1}$ To the Ez'oning Journal the Republican defeat meant the abandonment by the people of the great principle of the War." Republican apathy." unworthy nominees, "Democratic reaction," and fraudulent voting in New York City, ${ }^{6}$ were among other causes enumerated by the Republican State organs. The causes given for the Republican defeat were essentially the same in the Democratic State papers. ${ }^{7}$

The attitude assumed by the Democrats was one which largely showed their appreciation of the fact that the victory had not been entirely due to their own energies. The Irorld wisely warned the Democrats not to forget themselves in their jubilation.

It will not do to assume that we have won by a simple exertion of our own party strength. The fact is true, whether we recognize it or not, that we are indebted for this magnificent and manifold triumph to citizens who have not, for the last few years, acted in the Democratic party.

A further aid to the Democrats was acknowledged by the

${ }^{1}$ Buffalo Express, Nov. 7, I867.

- Albany Eacuing Journal, Nov. 6, 1867.

- Syracuse Daily Standard, Nov. 6, I867.

- Ibid. Albany Eacuing Journal. Nov. 6, I867; Utica Morning Herald, Nov. 6, i 867.

- Rochester Daily Democrat. Nov. 6, i867.

- See John 1. Davenport. The elcction and naturalization frands in Now York City, I860-70 (New York, I894), p. Ioo ct seq. Ibid. Utica Morning Herald, Nov. 6, I867.

"Rochester Daily Union and Adiertiser. Nov. 6, i867; Buffalo Daily Courier. Nov. 8, I867; Utica Daily Obsercer. Nov. 6, I867.

${ }^{8}$ New York World, Nov. 7. I867; Buffalo Daily Courier. Nov. 8, 1867 . 
World, in that " a proportion of the Republicans" stayed away from the polls, thus lending indirect help. It was urged that the true policy for Democrats to follow would be to render it easy, or at least, not difficult, for the liberal Republicans to act with the Democrats in the approaching presidential election. ${ }^{1}$ The general lack of worry on the part of the Republicans over their defeat was quite apparent. "The best thing that could happen to us:" "Just what we need:" were common expressions among the cheerful Republicans. ${ }^{2}$ The shrewder Democratic journals, following in the wake of the World, fully understood the inevitable reaction unless the party pursued a conservative policy.

${ }^{1}$ Cf. Harper's Weekly. Nov. I I, I867, p. 738 .

'Harper's IVeekly, Nov. 23, I867. 


\title{
CHAPTER IX
}

\section{The Constitutional Convention of i 867}

\author{
COM POSITION
}

TuE New York State Constitutional Convention, which has been referred to in describing the campaign of 1867 , was held under a new plan of representation. ${ }^{1} \quad$ The legislature passed an act in March providing for a convention to revise the constitution. The election for delegates was held on April $23 \mathrm{rd}$ and the delegates then chosen were to assemble at Abany on the first Tuesday in June. ${ }^{2}$ The aggregate

'Tribune Almanac, i87o, p. 32. Amendments submitted since Constitution of 1846 went into effect were:

In I849. On a Free School Law :

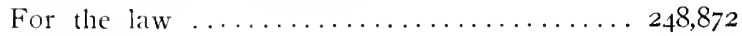

Against the law ................. 9I,95I

In 1850 . On repeal of the new School Law :

For ............................. 184,208

Against $\ldots \ldots \ldots \ldots \ldots \ldots \ldots \ldots \ldots \ldots \ldots \ldots, 209,347$

In 1854. Completion of Canals :

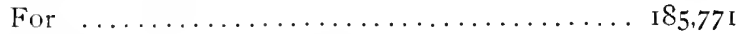

Against ........................ 60,526

In I858. On a New Convention:

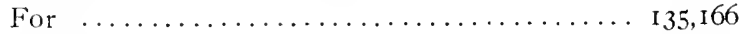

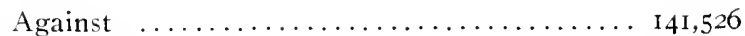

- Anuual $C y c$. I 867, p. 543. All persons entitled to vote for a member of the assembly might vote for the delegates. The powerful sectional feeling still rife was shown in the provision which required a voter, if challenged, to prove his loyalty by taking an oath of allegiance, and swearing that he had not borne arms against the United States voluntarily, nor aided the enemy of the North, nor held any real or colorable office in hostility to the United States, nor voluntarily supported such authority. Further, he had to swear that he was not a 
number of delegates was fixed at 160 , each senate district being allowed four delegates. Thirty-two delegates were chosen by the electors of the entire State, but no elector could vote for more than sixteen of them. State conventions ${ }^{1}$ were held by the political parties, who each nominated a ticket of sixteen names, hence the manner of voting insured the success of the entire ticket of each party for delegates at large.

The result of the election on April 23rd gave a majority of thirty-four to the Republicans. ${ }^{2}$ While in a measure it is invidious to select names from among the delegates. still mention of a few of the more familiar will convince one that the men chosen for the convention were of large calibre. From among the delegates-at-large we might select Waldo Hutchins, William M. Evarts. George Opdyke. George William Curtis, Horace Greeley, Ira Harris, William A. Wheeler, Charles Andrews, Charles J. Folger, Henry C. Murphy, Joshua M. Van Cott, Homer A. Nelson. Alonzo C. Paige, Francis Kernan, George F. Comstock and Sanford E. Church. From among the districts, the first sent William Wickham; the second. Daniel Barnard; the fifth, Elbridge T. Gerry: the seventh. Samuel J. Tilden; the twelfth. John M. Francis; the thirteenth. Amasa J. Parker: the nineteenth, Theodore W. Dwight: the twentysecond. Thomas G. Alvord; the twenty-ninth. Thomas T. Flagler, and the thirty-second, George Barker." There were men famous in State and national life, judges, lawdeserter, nor had left the State in order to escape the draft during the War. These qualifications were declared unconstitutional by the Court of Appeals, sustaining the judgment of the Supreme Court. It was decided that the legislature could not add to the qualifications fixed by the constitution. Green v. Shumway, 39 N. Y. 418, June, I865.

${ }^{1}$ Annual Cyc., 1867, p. 543.

- Republicans, 97 ; Democrats, 63-Rep. maj., 34.

- Coniention Documents 1867-8, vol. i, pp. I-3. 
yers, statesnen, jommalists, historians and business men. The personnel was well qualified to perform satisfactorily any business that might come before the convention. It was sufficiently conservative to give a stability to a convention which had been called to revise and improve the order of society rather than to overturn and rebuild. In accordance with the act the convention met at the capitol on June t. 1867. William A. Wheeler, from Malone, was chosen president. ${ }^{1}$ He was a quiet man of tremendous ability, a tireless worker and beloved by all. Luther Caldwell was made secretary of the convention, which immediately set to work under its various committees.

\section{THE JUDICIARY ARTICLE}

Probably the judiciary article of the constitution had caused more dissatisfaction than any other portion. ${ }^{2}$ Predictions of its failure had been many in the convention of 18+6. The fact that it had proven difficult if not impossible for the judges to perform their functions properly was soon discovered to be the fault, not of the men, but of the system. It could hardly be expected that with eight coordinate appellate tribunals in the Supreme Court, judicial harmony would result. This, in addition to an annual change of half of the Court of Appeals, made it practically impossible for that court to perform its function properly, certainly, not with the promptness that would have obtained had members been chosen for longer terms. The latter court was without doubt in the greatest need of attention. The judiciary committee appointed on June igth

${ }^{1}$ Later vice-president of U. S. under Pres. Hayes.

"Proceedings and Debates, vol. iv, p. 2576. Mr. Alvord, of Onondaga, said: "I think that I am speaking the truth when I say that the greatest of all matters which called for this convention at the hands of the people was some reform in the judiciary." 
was composed of fifteen of the convention's strong men. ${ }^{1}$ " Their patriotism, their high character, their great talents, their distinguished public service, their successes at the bar, in literature, and statesmanship," says Charles Z. Lincoln, " have made them famous in the annals of New York." On August 3 oth, thirteen nembers of the committee joined in a report ${ }^{3}$ presenting a complete judiciary article. Milo Goodrich, of Tompkins, presented at the same time a minority report which differed radically from that of the majority in the organization of the Court of Appeals and Supreme Courts.

The Court of Appeals received the most serious attention of the committee. ${ }^{4}$ The majority report proposed a Court of Appeals composed of seven elected judges who should hold their office during good behavior until the age of seventy years. One of the seven should be designated by his colleagues to act as chief judge through his continuance in office. They were also to have power to appoint or remove a clerk, a reporter, and such other attendants of the court as the law should authorize. ${ }^{5}$ The minority report likewise proposed a court of seven judges, who were to be elected by the people. however, for terms of fourteen years.

1 New York Concention Documents, vol. iv, doc. 107, p. I. The judiciary committee was composed as follows: Charles Folger, William M. Evarts, George F. Comstock, Joshua M. Van Cott, Charles P. Daly, George Barker, Francis Kernan, Waldo Hutchins, Joseph G. Masten, Theodore IV. Dwight, Amasa J. Parker, Charles Andrews, Matthew Hale, Milo Goodrich, Edwards Pierrepont.

- Lincoln, Constitutional History of New York, vol. ii, p. 248.

- Proceedings and Debates, vol. ii, p. 2288 (i867-8). Although approving of the majority report, Mr. Comstock withleld his signature because of the absence of a provision which was later adopted.

- In the court for the trial of impeachments, neither proposals nor changes were made.

- Concention Documents, 1867-8, vol. iv, no. 107, pp. 2-3. 
The terms of the judges elected under this system were so arranged that one term would expire every two years, the chief judge being designated by his associates. Both the nuajority and minority reports allowed the Governor to fill a vacancy by appointment until an election could be held.

November 2 ist saw the beginning of a protracted debate on the judiciary article. ${ }^{\prime}$ The amendments proposed upon the reading of the committee's report were numerous and perplexing. Mr. Ferry proposed an amendment which resembled the minority report, with this difference, that the judges should reside during their tenure of office at the place where the court was held and that the court should always be open for business. The chief objections offered to this amendment were that it would impose too great hardships upon the judges. Mr. Smith, of Fulton, also proposed a plan similar to the minority report. He opposed the system of life tenure for judges.

If a bad man comes into office ${ }^{2}$ his vices are stereotyped for us and there is no escape from him during his life. If, on the contrary, a judge be elected for a term of years and proves incompetent or unworthy, when his term shall have expired he will be out of the way and a suitable man can be elected in his place."

Mr. Baker proposed nine instead of seven judges and a term of twelve instead of fourteen years. ${ }^{4}$ His idea was to have a court large enough in numbers to adequately dis-

${ }^{1}$ Concention Documents, i867-8, vol. iv, no. 107, pp. I5-58. The judiciary committee early in its sessions, for purposes of reference, requested Mr. Charles P. Daly and Mr. T. W. Dwight to prepare papers upon the French, Scotch and English judicial organizations. Mr. Daly prepared the paper upon the French Courts, Mr. Dwight those upon the Scotch and English.

'Constitutional Proceedings and Debates, vol. iii, p. 2167.
3 lbid.
Ibid.. p. 2 I67. 
charge all duties incumbent upon them without the need of resort to a commission. Mr. Wakeman, continuing the debate upon November 22nd, declared himself opposed to an increased number of judges. He proposed to continue the number of judges at seven, but to have six of them elected for twelve years, while the Governor was to appoint a chief judge who should hold his office for a term of twelve years.' Mr. Harris, of . Albany, offered a substitute to the minority report. ${ }^{2}$ It provided that seven judges should be elected in the first instance, one of the seven going out of office every second year, ${ }^{3}$ the one having the shortest term to serve as chief judge, and that no judge who had served fourteen years was to be re-elected. Mr. Beckwith, of Clinton, offered an amendment which called for seven judges, one of whom should be appointed by the Governor with the consent of the senate, who should liold office for twelve years. ${ }^{4}$ Mr. Beckwith late in the debate agreed to accede to Mr. Harris' suggestion that the term of office of the chief judge be reduced to twelve years. The chief objection to this proposition was that it would break the unity of the court by creating one man more powerful than the rest.

Mr. Daly, who was then one of the existing judges upon the Court of Appeals, on December 5th gave an historical

${ }^{1}$ Constitutional Procecdings and Debates, vol. iii, p. $2 \mathrm{I} 72$.

'Ibid., p. 2187.

'Ibid., p. 2rgo. They were to be classified thus: the tenture of one judge would be for two years; of another for four years; another six; another eight; another ten; another twelve; and still another fourteen years. The chief judgeship would pass down from the judge first going out of office. Each judge would be chief judge for two years, hence avoiding any friction among them in the effort to obtain office. This proposition came to a vote, but was declared lost, only the ayes being counted, which were 23 .

‘lbid., vol. iii, pp. 2 I90-I. 
resume of the defects in the judiciary system, to the disparagement of the system under the constitution of 1846 . Mr. Comstock, of Onondaga, a brilliant lawyer and judge, followed him with a proposal for a court of seven members, to be chosen by the electors for a term of fourteen years, who should be ineligible for a second term. ${ }^{1}$ "At the first election of judges under this constitution, every elector may vote for the chief and only for four of the associate judges." " No chief judge or associate judge was to remain in office longer than the first day of January next succeeding his seventieth birthday. Mr. Pond proposed an annendment " which provided for ten judges in the Court of Appeals to be composed of four from the present court and provided for the election of six more, giving each voter the right to vote for four of the candidates. The term of office was to be ten years, with one retiring and one elected each year. The court would be held every two months. Provision was also made to designate the chief judge and judges who should hold terms so that one-half of the court could hold each alternate term. Mr. W. C. Brown proposed ${ }^{*}$ a court of nine members which should include those then in office. "The judges shall divide from time to time into two classes, which classes shall be co-ordinate courts and shall hold sessions at such times as the general court shall appoint. The chief judge shall divide the calendar between them"... three or more judges were to constitute a quorum for a class. Mr. Graves, of Herkimer, proposed a Court of Ippeals composed of eight members, of whom four were to be elected for eight years and four selected from the judges of the Supreme Court having the

1 Proceedings and Debates, vol. iii, p. 2366.

Ibid., pp. $2367-8$.

s Ibid., p. 2383 .

thid., pp. 2398-9. 
shortest time to serve. One of the four elected was to be designated as chief justice. Mr. Graves also proposed an elected judicial commission of five nnembers which was to continue for four years and hear the causes then pending before the present Court of Appeals.

The above proposals give in brief a general idea of the extent and nature of the changes deemed wise by some. Many other propositions of a minor character were advanced. All the plans save one had as their basis the elimination of the Supreme Court judges from the Court of Appeals. The variation in the length of term in office was marked. It was this question over which the convention became divided. The number of judges brought forth varying suggestions, ranging from five to ten members, which met with general approval. The methods of judicial selection proposed also displayed a fair degree of unanimity. Election seemed to be considered the best way, though champions of the appointive method were not absent. The length of term brought a long and able discussion. As before noted, life tenure had been agreed upon by the majority of the judiciary committee. This included tenure during good behavior, and ended, in any event, when the judge had become seventy years of age. The other plans proposed a fixed term which ranged from eight to fourteen years. Re-eligibility after the longer terms was also prohibited. ${ }^{1}$

Judge Comstock ${ }^{2}$ and Judge Daly, ${ }^{3}$ who had both been

${ }^{1}$ It seems, as suggested in the debate, that the term of fourteen years was applied because that appeared to be the average length of service in the courts of New York, other States and of the United States, where the tenure during good behavior had been applied.

- Speeches may be fonnd, Proceedings and Dcbates, vol. iii, pp. 2288-9, $2300,2383,2440,2536,2600$.

Ibid., pp. 2359-65, 2372-4; vol. iv, pp. 2459, 2640, 2705-6. Mr. Daly gave a complete historical review of the changes made in our judicial 
upon the Court of Appeals, put forth able and lengthy arguments in support of the majority report. It remained, however, for Wm. M. Evarts, with his inimitable skill and learning, to urge the position of the committee. He stood for the principle of good behavior during the period of judicial usefulness. He went into the political theory back of the judiciary at some length, stating that the judiciary is the representative of the justice of the State and that judicial service in its true sense was to declare the law, not to impose it. The two considerations in choosing judges were:

first, how shall they best be selected, and second, how, having been thus selected, they shall best be preserved, built up, fortified, ennobled in their sentiments, in their character, in their

system by the conventions of $I_{2} 8_{2}$ and ${ }_{1} 8_{4} 6$, and the defects as pointed out. After developing historically the judiciary of England and the United States, he showed that the age-limit of seventy was not too old: with illustrations from the history of our own and of the British judiciary. "Lord Kames... was an able and vigorous judge at eighty-five. Lord Mansfield sat with undiminished power at the age of eighty-two. Lord Chancellor Lyndhurst made one of his greatest epeeches, and one of the most effective ever heard in the House of Lords, when he was eighty-one. Chief Justice Marshall presided in the Stipreme Court of the United States with his intellectual factilties nnimpaired at the age of seventy-nine. Chancellor Kent wrote his Commentaries when, by the constitution of this state, he was no longer intellectually competent to be a judge, and he continued to revise and edit them... until he was past eighty. . . During the seventy years that the judges of this state held their office during the tenure of good behavior, we had a judiciary that would compare with any age of our country."

Ibid.. pp. 2172-4, 2187, 2197-8, 2201-2, 2223-6, 2300-3, 2448, 2507. Amasa J. Parker, who was also a member of the Committee and had signed the majority report, believed the independence of the judiciary could be maintained by one long term.

Ibid., vol. iii. p. 2189 , also pp. $1287,2203,2206,2295$, 2296; vol. iv, pp. 2627. 3714. Joshua Van Cott made an able speech in defense of the majority report. 
repute and their authority, before the eyes and in the opinions of the community, in the administration of whose justice they are to preside. ${ }^{1}$

Mr. Evarts next stated that the judge should hold his office during the pleasure of no representative of political power. "Durante benc placito, is exploded from our system." He maintained that the mind of the judge while on the bench should not be conscious of any effect upon his political chances through his acts upon the bench. He should feel and be unaccountable except for impeachable offenses. Evarts claimed that in order for the State to obtain the services of the "ten talents" man, "she must offer hm a career commensurable with the talents, and the character, and the duty that belong to him as a man." 2 Mr. Evarts pleaded eloquently for the lawyer, who, having accepted service in the highest judicial tribunal of the State at loss of the emoluments and opportunities of his chosen profession. finds himself at the end of his term, where it is inited. forced to return to his profession with the great endeavors consequent upon rebuilding his practice, or to find a new rocation in which to spend his declining energies.

This supremacy, this authority that I desire is not personal. It is all official. It is to help the Judge's office, not to aggrandize the Judge in his person. . . . I wish to see it impressed upon the mind of the bar, I wish the bar to understand that the election of a judge to a seat on the bench is not only for the life of the judge, but it is for the lives of his contemporaries at the bar. I wish them to feel that they are not . . at liberty to plan for temporary occupancies of the bench, reserving for themselves the future chance when they beconie ripe for it. ... Let us have the reflex influence of an independent judiciary upon an independent bar. Let us work together."

${ }^{1}$ Proceedings, vol. iii, p. 2367. 'Ibid., p. 2360. 'Ibid.. p. 2370. 
Mr. Evarts admitted that the difference on the question was largely one of degree; whether there should be a fourteen-year tenure or tenure during good behavior, both with an age limit. It is impossible for an intelligent student of political systems not to become enthused and inspired with the method in which he put forth his facts. Evarts wals then in the prime of his great career. Charles Z. Lincoln says, in speaking of this address:

Even now, reading the speech after thirty-five years, we fall under the spell of the orator, and can readily understand how, as he rose to the height of that great argument, the Convention hesitated, and almost decided to abandon a fixed judicial term, and restore the ancient tenure during good behavior, with an age limit, which had controlled in the Colonial days, and through the first seventy years of our state history. ${ }^{1}$

But upon Decenber th. Mr. Hale's amendment of tennre luring good behavior, or until judges reach the age of eventy years, ${ }^{2}$ was rejected by a vote of +3 to $48 .{ }^{3}$ The second test came npon Mr. Evarts' motion made December roth which was similar to the above, the result being the same by a vote of 56 to $58 .^{4}$ The final vote on this muchcontested point, February igth, just at the adjournment of the convention, "brought forth on the motion of Erastus brooks the same result, the vote being 45 to $6 \mathrm{I}$. Out of a convention of 160 delegates, 69 were absent for the vote on the first of the above questions, 46 on the second and 64 nipon the third." On the final ballot less than one-third es-

${ }^{1}$ Lincoln, Constitutional Hist. of N. Y., vol. ii, p. 256.

- Proccedings and Dibates, vol. iii, p. 2374.

Ibid., p. 2382.

tIhid., vol. iv. p. 2635 .

Adjournment Feb. 28th.

- Ilid., vol. v. p. 3727 . 
tablished the length of tenure. With the exception of the abnormal conditions at the time of the convention of 1776 I777, no convention had made such important changes in the constitution with such a small proportion of the delegates present. ${ }^{1}$

While those who advocated the fourteen-year tenure were firm for an independent judiciary, they believed the result would be accomplished by making the juclge ineligible for re-election. There were those who believed that the judge might neglect his official duties at the end of his term in the interest of his re-election. ${ }^{2}$ Others thought that even with a long term, a judge might go out of office not disqualified by age but embarrassed on re-entering his profession because of a long absence. However, the opinion prevailed that if the service of the judge had been satisfactory he would be re-elected without such effort upon his part as to detract from his official duties. ${ }^{3}$ The question of re-eligibility of the judges produced much discussion and considerable wavering. Mr. IVakeman's motion for reeligibility was carried by the rather large majority of 70 to 42. ${ }^{4}$

Time has shown that the suggestion so eloquently spon-

1 Rerised Record of the Constitutional Convention of I894, vol. i, pp. 2-6. In the Convention of I894, no amendment was deemed made mnless two-thirds of those present had given it their affirmative vote. This was later set as a permanent figure. There were 169 delegates at the convention of 1894 .

'Procecdings and Debates, vol. iv, p. 2580 .

${ }^{3}$ Ibid.

"Ibid. Mr. Young upon this point said: "A judge who metes out even-handed justice to all, who has an upright and honest heart in his breast. . need not fear his constituents when nominated for reelection. . . I have no douht that he and judges who have shown themselves capable and worthy will be kept in office by the people, and appreciated by them as long as they are competent to discharge the duties of a judge." 
sured by Mr. Evarts, establishing the tenure of the court during good behavior with the age limit at seventy years, would have produced none of the fears augured. The operation of the fourteen-year rule has produced practically the same result. ${ }^{1}$ Of the fifteen judges who have béen elected, not including those in office on January I, I9I I, their age at election averaged fifty-three years. It varied from forty-three to sixty-one years; six were under fifty. ${ }^{2}$ The average length of service of the judges elected, not in-

'Lincoln, Const. Hist. of New Jork, vol. ii, p. 26r. Of the fifteen, Judges Church, Peckham, Sr., Grover, Allen and Ruger died in office. Judge Rapallo, on being re-elected to a second term, died shortly afterward. Judge Folger, who was chosen to the Chief Judgeship in $189 \mathrm{I}$, before the expiration of his first term, resigned to take the Treasury portfolio in President Garfield's cabinet. Rufus W. Peckham, Jr., who was elected in 1886 , resigned in 1895 to take a seat upon the United States Stipreme Court. Judge Finch served a full term. He retired December 3I, I895, but had he been under the tenure proposed by the majority report of the Judiciary, he might have served until his seventieth birthday, June 9, I 897 . Chief Judge Alton B. Parker, in order to accept the candidacy of the Democratic party for the Presidency, resigned Augnst 5. 1904. Judge Martin, elected in r895, retired Decenher 31, 1904, having passed the age-limit. Judge Gray was re-elected to a second term in 1902 , and may serve nntil the age-limit. December $3 \mathrm{I}$, 1913. This wonld make a total of twenty-five years of judicial service for him, exclusive of one year under appointment. Judge O'Brien served until December 3I, 190\%, having been re-elected in 1903 . This made his total length of service eighteen years. Hence eleven JudgesChurch, Peckhan1, Sr., Grover, Allen, Ruger, Rapallo. Earl. Miller, Danforth, Andrews and Martin-held office under the fourteen-year rule, which service would have been the same under the tenure for life proposed by the majority report. We see also that the term of the three judges who resigned wonld have been the same under either rule.

2] have not inclnded the figures for the full number of judges (twenty-three) who have been elected to the Court of Appeals up to January 1, I9II, heeanse of the impossibility of exactness, due to the probability of death while in office, resignation from or re-election to office. 
cluding those in office on January I, I9II, was ten and four-tenths years. ${ }^{1}$

In the first section of this chapter attention has been called to the attempt made to organize a commission of appeals. $^{2}$ The sentiment of the convention seemed to hold, that the new court should not be overloaded with the business which had been accumulated in the superseded court. The report of the judiciary committee had recommended the inclusion of the former court for that purpose, with another commission to be appointed by the Governor." All causes pending in the Court of Appeals on January I, I868, were to be heard and determined by the commission. It was further provided by the report, that the legislature should have the power to create a new commission, to hear and determine any causes that might be transferred by the Court of Appeals to it at the end of ten years from the adoption of the constitution as revised. ${ }^{4}$ This section providing for a commission after ten years was stricken out upon motion of Mr. A. J. Parker.

\section{THE SUPREME COURT}

The principal disagreement in the convention of 1867 over the Supreme Court came on the matter of terms. Little desire was manifest to disturb the judicial districts. The great cry against the Supreme Court had been the eight appellate tribunals, which perforce produced conflict of decisions. Many proposals were made in respect to the Supreme Court which would bring about the reform desired, but only the most important will be given here. The majority report proposed that the State should be divided into

\footnotetext{
${ }^{1}$ Lincoln, Const. Hist., vol. iii, pp. 26r-2.

2 Vide, supra ch. ix, p. 219.

'Convention Documents. (1867-8), no. 107, p. 3.

Ibid. (1867-8), no. I07, p. 4.
} 
four judicial departments, each of these into two districts to be bounded by county lines. The City and county of New York were to form one district, with ten justices. The other departments were to have eight justices each, making a total of thirty-four for the State. The legislature was given power to provide for an additional justice in each of the departments, and one-half of the justices in each department were to reside in each district of the department at the time of election. Four of the judges were designated to hold special terms and circuit courts or to preside in any court of oyer and terminer. Provision was made for designation of the justices who should hold general terms and also of the chief justice, who should hold during his continuance in office. ${ }^{1}$ As in the Court of Appeals, no justice of the Supreme Court could sit in review of his own decisions. ${ }^{2}$ They were to be elected by departments and were to hold office during good behavior until the age of seventy. ${ }^{3}$

The minority plan, written by Mr. Goodrich, proposed the division of the State into three departments. These departments were to consist of the existing judicial districts, each department to have twelve justices, holding for twelve years after the first classification. The elections were to be by departments, each district to be the residence of an equal number as far as possible. The legislature could not legislate a judge from office, though it had the right to add an additional justice to each department or to reduce the number. The presiding justice for each general term was to be selected by said term. He could not hold trial or special terms or grant orders renewable in the general term. The presiding justice's chief single power consisted in the ap-

${ }^{1}$ New York Conzention Documents ( I867-8), vol. iv, pp. 5-6.

'Ibid., 5.

${ }^{3}$ Ibid., 9. 
pointment or removal of the Supreme Court reporter. Two of the general term justices were to retire at the end of every second year, other justices to be designated for their places. The presiding justice was an exception to this rule. ${ }^{1}$ In each judicial district general terms were to be held for the hearing of causes arising therein. ${ }^{2}$

We will simply mention the more prominent of the various other proposals for the Supreme Court. Mr. Judson S. Landon proposed the abolition of the Court of Appeals. He would place appeals in the Supreme Court only. Matthew Hale provided for a Supreme Court composed of twelve judges, ${ }^{3}$ to be chosen from the State at large, while eighteen justices, four in New York, and two in each of the other districts, were to do the circuit work. Each district was to have general terms, to be composed of three judges chosen at large. He also suggested a "state term" to be held once yearly by seven of the Supreme Court judges. ${ }^{4}$ Under a plan proposed by Mr. Elizur H. Prindle, the State would be divided into three judicial departments composed of the judicial districts then existing. Each department was to have a general term composed of four justices, who should have no other jurisdiction. ${ }^{5}$

The convention changed the judiciary committee's proposal which had recommended the election of justices by departments, to election by districts. ${ }^{6}$ On motion of Judge

1 Procecdings and Debates, vol. iii, p. I626.

"Revised Record of the Constitutional Coniention of 1894, vol. v, p. 757. One may see here the germ of the Appellate Division as now in operation, provided for by the Constitutional Convention of 1894 .

'Constitutional Concention Proceedings and Debates, vol. iv, p. 24 I5. Mr. Hale states that for purposes of distinction he has called in his plan the men e'ected by the State at large "judges, while those elected by districts, Justices."
'Ibid., pp. 2414-5.
- Ibid., p. 2460 .
- Ibid., p. 3708 . 
Comstock the term of office was fixed at fourteen years. ${ }^{1}$ The age limit was fixed at the first day of Jamuary next after the justice shall have arrived at the age of seventy, on motion of Mr. Prindle. ${ }^{2}$ This date was set forward to December 3 Ist, afterwards.

To make a brief summary of the action of the convention in regard to the Supreme Court, we see that it was continued as it then existed with the same number of justices in each district. Each justice was elected for a full term of fourteen years, an extension of eight years, with no rotation in office. The legislature was given power to establish not more than four general terms. The general term might consist of four justices. They would not be organized oftener than once in five years. The requirement was made for a general term to be held in each judicial district. No justice could sit in review of his own decision.

Chapter 408 of the Laws of 1870 put the new judiciary article into operation. The first department was to consist of the first district: the second, of the second; the third. of the third, fourth and sixth districts; and the fourth, of the fifth, seventh and eighth districts. ${ }^{3}$ A presiding justice, who should so act during his official term, and two associate justices were to compose the general terms. The latter were to act in such capacity for five years from Decenber 3 Ist next following their appointment.

${ }^{1}$ Constitutional Conicntion Proceedings and Debates, vol. iv, p. 2575.

'Ibid., vol. iii, p. 2281.

- This statute required general terms to be held in the city of New York for the first department: in Brooklyn and Poughkeepsie for the second department: in Albany and Plattshurgh for the third department; and in Buffalo. Binghamton and Elmira for the fourth department. 


\section{MINOR COURTS}

The convention found the county court as it had been left by the convention of 1846 . It is true that various attempts had been made since that time to enlarge the jurisdiction of the county court but without success. The general opinion of the convention of 1867 was in favor of an extension of jurisdiction. The plan of the majority report of the judiciary committee was that the county court was to have such original and appellate juriscliction as the legislature might see fit to confer from time to time. ${ }^{1}$ The minority report proposed practically the same jurisdiction, though it differed in certain other respects. ${ }^{2}$ The convention concluded that jurisdiction should not be conferred upon the county courts in general terms but should be limited to definite money actions. Hence, the suggestion of Mr. Henry O. Cheseboro was adopted, which gave the court original jurisdiction in cases where the parties resided in the same county and the damages claimed amounted to $\$ 1,000 .^{3}$ Upon its acceptance Judge Comstock at once moved that the jurisdiction be made subject to the power of removal to the Supreme Court. ${ }^{*}$ Inasmuch as the length of term of judges of the Court of Appeals, the Supreme Courts and certain city courts had been extended. it was thought right to do likewise to that of the county judges. The majority report had proposed seven years. ${ }^{5}$ the minority four years. ${ }^{B} \mathrm{Mr}$. Cheseboro proposed six years, which term was accepted by the convention. ${ }^{7}$ Judge

${ }^{1}$ Convention Documents, vol. iv, no. I07, p. 9.

2 Proceedings and Debates, vol. iii, p. 1627.

'Ibid., vol. iv, pp. 2594, 267 I.

${ }^{5}$ New York Con. Docs., vol. iv, no. Io7, p. 9.

- Proceedings and Debates, vol. iii. p. I627.

"Ibid.. vol. iv, p. 2675. 
Comstock put through in the convention a motion to the effect that the salary of the county judge should be fixed by law instead of by the board of supervisors. ${ }^{1}$ This proposition as advanced by Mr. Ketcham had been lost. ${ }^{2}$

When the surrogate's courts were reached, the committee took some advance steps. The provision, as in the former constitution, under which the county judge in the smaller counties acted as surrogate was continued. In the more populous counties, the legislature was given power to create a separate surrogate's office. The following passage in the section proposed by the committee gave the convention much food for thought.

The Legislature may create probate courts, abolish the office of Surrogate, confer upon existing courts the power and duties of Surrogate and the jurisdiction of Surrogates, create registers of wills and of the probate thereof, and of letters of administration, and provide for the trial by jury of issues in Surrogates Courts and in courts having the like powers and duties."

Mr. Evarts made remarks to the effect that the probable increase of wealth and population in what is now Greater New York would bring a corresponding increase in the number of probate cases, and that it might be "desirable that the legislature should have the power to separate the mere official duty of the surrogate, as the register of wills,

1 Proceedings and Debates, vol. iv, p. 2674.

'Ibid., p. 2608. Mr. Ketcham had proposed to abolish the office of justice of sessions, but was voted down. Of these officers he said: "I never knew of an instance where these officers were consulted and influenced the dec:sion of the court that they were not wrong. They are mere 'figure-heads,' and answer no purpose but to sit up there and look wise and draw their pay." Proceedings and Debates, vol. iv, p. 266r.

- New York Constitutional Conention Proceedings and Debates, vol. iv, p. 2634 . 
and in taking formal proof of uncontested wills and issuing testamentary papers and letters of guardianship, from the true judicial functions now discharged by the surrogate." 1 Mr. Evarts, doubtless, would be amazed, could he visit the surrogates' offices in New York City at the present day, where he would find a far greater differentiation in the surrogate's work than he may have ever dreamed. Mr. E. A. Brown proposed to substitute for the committee's report the following: "the legislature may provide for the trial by jury of issues in the surrogates' courts." ${ }^{2}$ This was adopted by a vote of 46 to $26,{ }^{3}$ but it was immediately voted down on Mr. Ramsey's and Judge Constock's motion to strike out the Brown substitute. ${ }^{*}$ Judge Comstock stated that such a measure would send all issues of fact to a jury, and that the large proportion of facts should be disposed of without a jury. However, Mr. Folger, not to be downed, reported on the day following from the judiciary committee a section which vested the legislature with power to confer on courts of record in counties with a population which exceeded 400,000, "the powers and jurisdiction of surrogates, with an authority to try issue of fact by juries in probate cases." 5 This was adopted. ${ }^{6}$

The conservative tendency of the convention was shown in the lengthy contest over the resubmission to the people

${ }^{1}$ New York Constitutional Convention Proceedings and Debates, vol. iv, p. 2634 .

Ibid., vol. v, p. 3724 .

Ibid., p. 3725 .

Ibid.

"Ibid., vol. v, p. 3776 . This authority was not applied until 1886. sixteen years after it was put in the Constitution, and then it was limited to the Court of Common Pleas.

"In 1895 this act was amended and made applicable only to the Supreme Court. The Code was also amended by Chapter 946, Laws of 1895. In 1892 relief was afforded New York C'ty without the creation of ano'her surrogate court by the creation of two surrogates in a single court. 
of the question whether judges should be appointed or elected. The method pursued in the earlier history of the State had been almost exclusively that of appointment. In I867. when the convention asked the people to vote anew upon the question, twenty years had passed since the adoption of the policy of judiciary election. The plan proposed by the judiciary committee originally provided for the election of judges. However, the report also contained a provision which asked the people to decide whether the elective plan should be continued or the appointive plan restored. The idea was that if the people ratified the constitution, which in its terms provided for the election of judges, the constitution as ratified would provide the people with an opportunity at some time later to change the method of judicial selection. The division of the convention upon the point is shown by the vote on a motion made by Mr. E. A. Brown to strike out the section, which was lost by the vote of +2 to $43 \cdot{ }^{1}$ Judge Comstock's motion limited the section to judges of the Court of Ippeals and justices of the Supreme Court. ${ }^{2}$ However, this was modified by Mr. Folger's motion which brought about the submission of two propositions: " the first, to include the judges of the Court of Appeals and justices of the Supreme Court; the second, county judges, judges of the superior court of Buffalo, the superior court and court of common pleas of New York, and the city court of Brooklyn.

The new judiciary article went to the people at the November election of I869 and was approved. ${ }^{4}$ The statutes, passed early in the session of 1870 . called for an election

'Proceedings and Lebates, vol. iv, pp. 2545-6. Later tests slightly increased the margin, but they all showed that the convention was equally divided upon the question.

"Ibid., p. 2547.

"Ibid., p. 2707.

4 Tribune Almanac, I870, p. 51. For, 247,240: against, 240,442. 
May i 7 th. The judges elected at that time entered upon their duties the first Monday of July, i870, twenty-three years after the Court of Appeals was established by the constitution of 1846 .

In its final form the section on the question of judicial election or appointment provided for the submission at the general election in 1873 . The result showed that the people after twenty-five years of experience in the selection of judges were unwilling to relinquish their rights to choose their own judges. Both propositions ${ }^{1}$ were defeated by majorities exceeding 200,000.

\section{SUFFRAGE}

The summer months of I 867 were largely devoted to the question of qualifications for the exercise of the right of suffrage. The majority report of the committee "on the right of suffrage and the qualifications to hold office" was presented on July 28 th by Horace Greeley. The article on suffrage modified many important aspects of the existing constitutional provisions on this subject. The qualifications of voters were stated thus:

Every man of the age of twenty-one years, who shall have been an inhabitant of this State for one year next preceding an election, and for the last thirty days a citizen of the United States and a resident of the election district where he may offer his vote, shall be entitled to vote at such election, in said district, and not elsewhere, for all officers elected by the people.

The general standard was residence in the State. The requirement for a stated period of residence in a county was omitted. Idiots, lunatics, persons under guardianship.

${ }^{1}$ Tribune Almanac, 1874. p. 61. Election of judges: Higher Courts: For, 319,979; against, I15.337. Lower Courts: For, 319,660; against, 110,725 .

'Proceedinys and Debates, vol. i, p. 199. 
felons, persons convicted of bribery, persons who have been paupers thirty days next preceding an election, and persons who offer or accept a bribe were excluded by the section. ${ }^{1} \quad$ Further,

for the purpose of voting, no person shall be deemed to have gained or lost a residence by reason of his presence or absence while employed in the service of the United States, nor while engaged in the navigation of the waters of this state, of the United States, or of the high seas, nor while kept in any almshouse or other asylum at public expense, nor while confined in any public prison.'

The provision required election by ballot, registration of voters to be complete at least six days before election and uniformity throughout the State. An office holder had to be an elector and the existing official oath was continued. A minority report was presented by Mr. Cassidy and Mr. Schumaker. ${ }^{3}$ They did not subnit any sections in detail, but expressed their preference for the existing provision of the constitution on the qualifications of voters because they were well known and had been interpreted judicially.

The year's residence requirement prescribed by the former constitution did not occasion any objection. The majority of the committee favored the abrogation of the

1 Proceedings and Debates, vol, i, p. 199.

'Conzentional Documents (i867), vol. i, no. 15, pp. 2-3.

Ibid., vol. i, no. I6, rp. I-4.

'Proceedings and Debates, op. cit., pp. 235-6, 481, 483, 548-9. Under the discussion of disqualifications, Mr. Charles C. Dwight proposed to substitute the secions which were in the present constitution. Judge Comstock moved to strike out the clause "for all officers that now are, or hereafter may be, elected by the people." He believed the expression would lead to harm because of its looseness. However, his motion was lost. A motion made by Mr. Sanford E. Church was passed (7o to 67 ) to the effect that an elector should have the right to vote "upon all questions which may be submitted to the vote of the people." 
provision which required residence for four months in the county. ${ }^{1}$ This position was taken because of the large number of laborers who left the cities to work in the country and outside resorts during the summer and who could not afford two residences. ${ }^{2}$ Also, under existing conditions clergymen, who made frequent change of location in the summer, were disqualified. The provision which declared that a person should not be deemed while absent as a student to have gained or lost residence for the purpose of voting was omitted. ${ }^{3}$ The clause was believed to be unnecessary by Horace Greeley, because the convention could not determine a man's residence, which is the real test of his right to vote. " Mr. Elbridge G. Lapham "introduced a motion which was later amended to the effect that the voter must have been a resident thirty days in the town or ward, and ten days in the election district. ${ }^{6}$

The majority report required naturalized citizens to have completed their naturalization at least thirty days before election. $^{7}$ The minority report preferred the retention of the existing ten-day rule. ${ }^{8}$ In regard to persons disqualified, the committee's plan proposed to include the disqualifications already stated in the constitution, also others fixed by the statute. ${ }^{9}$ Registration was to be compulsory and

1 Proceedings and Debates, op. cit., p. 199.

Ibid., p. 227 .

- Ibid., p. 620; vol. v, p. 3570 . This provision was incorporated in the final form of the revised constitution in spite of the arguments of such men as Mr. Charles C. Dwight.

Ibid., vol. i, pp. 620, 569 .

${ }^{5}$ Ibid., p. 208.

- Ibid., vol. v, p. 3959.

' $N$. Y. Conzention Documents, I867, vol. i, no. I5, p. I.

${ }^{8}$ Ibid., no. I6, p. I.

9Proceedings, vol. i, p. 208. "Persons judicially declared to be of unsound mind, or incapable of managing their own affairs" was an addition suggested by $\mathrm{Mr}$. Lapham.

Ibid., p. 560. "The Legislature may provide by law that records 
must have been completed six days before election.' Educational qualifications were frequently proposed in the convention, but the committee refused to recommend such a test. After a long and arduous discussion over this point the original first section with certain amendments was substituted for the plan proposed by the suffrage committee. This clearly illustrates the conservatism of the convention in its preservation of well-known qualifications. ${ }^{2}$

The advocates of woman suffrage endeavored to tse the convention of 1867 as a means to advance their cause. When the legislature was considering the convention they argued for a right to vote for delegates. Although the senate was in favor of extending the franchise on delegates, it did not favor its use by women. ${ }^{3}$ The suffrage committee

shall be kept ... by the police authorities . . of all persons known to them to be engaged in illicit pursuits hostile to the community; and persons so engaged and ... recorded, under due provisions of law, shall be excluded from registration," was suggested by Mr. Duganne.

"N. Y. Convention Documents, I867, vol. i, no. I5. p. 3.

"Procecdings and Debates, op. cit., p. 544. "The people of this state, in virtue of their constitutional sovereignty, have the undoubted right to establish and regulate for thenselves the elective franchise without interference by any other authority whatsoever," was proposed by Judge Comstock for a preamble to the suffrage section.

'Lincoln, Constitutional History of Nea York, vol. ii, p. 312; Lalor, Cyclopedia of Political Science, vol. iii, p. 830 ; Proceedings and Debates, $o p$. cit., pp. $218,537,547$. The conferment of suffrage upon taxpaying women was proposed by Mr. Gideon Wales. This proposition, while it appears fair, was not taken up by the convention. Mr. Ezra Graves suggested that the question of "votes for women" be submitted to the women themselves at a special election. If the majority of the votes cast were in the affirmative, then all women should have equal suffrage with men. Horace Greeley opposed this proposition on the ground that "it compelled women to vote in order to avoid voting." He favored the submission of the question to women, but staggered those in favor of woman suffrage by proposing that all those who did not vote should be counted in the negative. 
refused to make a recommendation for elective franchise to women. In part it said:

However chesirable in theory, we are satisfied that public sentiment does not demand, and would not sustain, an innovation so revolutionary and sweeping, so openly at war with a distribution of duties and functions between the sexes as venerable and pervading as government itseif and involving transformation so radical in social and domestic life. ${ }^{1}$

George William Curtis championed the cause of woman suffrage in the convention in an eloquent address, the principal one upon that side. ${ }^{2}$

When the question of negro suffrage came before the convention it was not surprising that prejudices were still rampant, if one considers the dynamics of the struggle which had just closed and of the new struggle over Reconstruction just coming into its own. The report of the suffrage committee proposed to do away with all discrimination based upon color. It said in part: "Whites and blacks are required to render like obedience to our laws and are punished in like manner for their violation. Whites and blacks were indiscriminately drafted and held to service to fill our State's quotas in the War whereby the Republic was saved from disruption." ${ }^{3}$ Strong endeavors were put forth by the opponents of equal suffrage to colored men. However, they availed not. As the constitution proposed by the convention of 1867 was not accepted by the people, the color disbarment continued as in the constitution of 1846 until the adoption of the amendments of 1874 .

${ }^{1}$ N. Y. Concention Documents, op. cit., no. 15, pp. 6-7: Proceedings and Debates, op. cit., pp. 178-9.

2 Proceedings and Debates, op. cit., pp. 364-372.

- New York Convention Documents, vol. i, no. 15, p. 4. See Proceedings and Debates, vol. i, pp. 236, 253, 255, 312, 313, 349. 528. 
taking effect January 1,1875 . After the adoption of the Fifteenth Amendment on March $30,1870,{ }^{1}$ the operation of the discrimination in New York State was nominal.

THE BILL OF RIGHTS

The convention of I867 was no exception to the tendency to consider the principles upon which the constitution was founded. In consequence the Bill of Rights received certain modifications. Mr. Merwin suggested an amendment, when the jury section was under consideration, to the effect that " except in justices" courts provision may be made by law for trial by jury of less than twelve men." This was adopted by the convention. ${ }^{2}$ His aim, undoubtedly, was to remove any question concerning the right of the legislature to increase the civil jurisdiction of justices' courts. In 1856 the Court of Appeals had decided ${ }^{3}$ that a provision in the excise law of 1855 , which gave courts of special sessions jurisdiction over persons charged with its violation, was unconstitutional on the ground that they had a right to a common law jury of twelve men. ${ }^{4}$ Mr. Merwin's amendment was designed to avoid that question. ${ }^{5}$

${ }^{1}$ Art. xv, sec. I: "The right of citizens of the United States to vote shall not be denied or abridged by the United States or by any State on account of race, color, or previous condition of servitude Section 2. The Congress slall have power to enforce this article by appropriate legislation."

"Proceedings and Debates, vol. v, p. 3239.

"Wynehamer Case, I3 N. Y. 378.

4 Proceedings and Debates, op. cit., p. 3229.

'In I 868 it was decided in Dawson 2 . Horan, 5I Barb. 459, that a statute which increased the civil jurisdiction of justices courts was not unconstitutional in view of the fact that it required a jury of six instead of twelve men. This decision was followed and approved in Knight $v$. Campbell, 62 Barb. 16 (1872). 


\section{THE LEGISLATURE}

The conservatism of the convention was again strikingly shown when the structure of the legislature was discussed. It was unanimously proposed by the committee upon legislative organization to divide the State into eight districts, as established in $182 \mathrm{I}$ but abandoned in $18+6$. However, the geographical arrangement of the districts was new. Under this plan the districts were practically coterminous with the judicial districts, provision being made for an additional senator in New York County. ${ }^{1}$ Further, this plan provided that one senator was to be elected each year for four years. ${ }^{2}$ The chairman of the committee, Mr. Edwin A. Merritt, gave the opinion of the committee when he said that in his belief the large district plan would " invite into the legislature the ablest minds of the State "." A practical turn from a political angle was given the debate by Mr. Solomon C. Young, who pointed out that, based on the election returns of $\mathrm{I} 866$, the first and second districts would send five and four respectively, as representatives of a $56,000^{5}$ Democratic majority in the two districts. On the other hand, from the remaining six districts the Republicans would elect twenty-four in all, representing a majority of about 92,000. ${ }^{6}$ Horace Greeley, in keeping with his minority representation, suggested fifteen districts, each district to elect three upon the cumulative plan. ${ }^{7}$ Among the various other plans suggested, Mr. Marius Schoonmaker proposed ten senatorial districts with four

${ }^{1}$ New York Concention Documents (I867), vol. i, no. 30, p. I.

2 New York County had special arrangements for the fifth.

3 Procecdings and Debates, vol. i, p. 648.

'Ibid., p. 688.

s Tribune Almanac, 1867 , p. $5 \mathrm{r}$.

Ibid., 1867, p. 51 .

'Proceedings and Debates, op. cit., p. 787. 
senators from each. ${ }^{1}$ The convention at length substituted $^{2}$ for the eight-senate-district plan of the committee the single-district system then in force. Minor changes, however, were made: four years was made the length of office, two classes of senators were made by dividing the odd and even numbered districts, one class was to be elected every two years. ${ }^{3}$

The same conservative plan was followed in the committee report when it touched on the assembly. It suggested an increase of eleven in the assembly, making the total 139 , and abandoning at the same time the method of the single-district system. ${ }^{+}$There appeared to be a united opinion in favor of an increase in the number of assemblymen but the suggestions varied from an increase of 128 to I68." The committee's assembly plan dicl not encounter much opposition. except the change from the single districts to election by counties. The latter, however, was sustained by the vote of 64 to $43 .{ }^{6}$ The convention adopted the proposition that all electors should be eligible to either house of the legislature. The legislator's salary was fixed at \$I,OOO and mileage. ${ }^{\$}$ Typical of Horace Greeley was the suggestion that the senators should receive no compen-

1 Proceedings and Debates, op. cit., p. 66I.

${ }^{3}$ By a vote of 79-35.

Ibid., vol. v, pp. 3959-6r.

-Ibid., pp. 3960-I.

s The latter was only defeated by a small margin. 52 to 62 . Other proposals were for I4I, I42, I43, I 45 .

-Ibid., vol. ii, p. 876. The vote upon Mr. Milton H. Merwin's amendment which raised the question whether nembers were to be elected from single assembly districts, or counties.

'Ibid., p. 869 ; vol. v, p. 3959.

$\checkmark$ The speaker of the assembly was given, in addition, an emolument equal to a member's salary. Vere York Conention Documents, vol. i. no. 30, p. 3 . 
sation other than the consciousness of honorable usefulness and the resulting gratitude of their fellow citizens. ${ }^{1}$

\section{THE EXECUTIVE}

Reports on the executive department were received from three committees. The regular committee on the Governor and lieutenant-governor made the main report. The committee on the pardoning power considered that section alone, while the conmmittee on legislative powers and duties returned a section on the legislative power at extraordinary sessions, in addition to the regular section relating to the Governor's action on bills. The compensation of the Governor and lieutenant-governor was to be fixed by the legislature, though the terms of office were left unaltered. In his message of r $867 .{ }^{2}$ Governor Fenton had suggested

1 Proceedings and Debates, vol. ii, p. 866. Among the large number of provisions suggested by the committee on the powers and duties of the legislature, which were already in the constitution, the following were in addition especially recommended: Biennial sessions of the legislature; special sessions, with power to consider subjects specified only by the Governor. No member was to be expelled from either house without a majority vote of its nembers, nor could one be expelled twice for the same offense. Further, there was to be no money or property appropriated without a legislative act. The legislature was authorized to create a Court of Clains. It also was forbidden to grant any extra compensation to a public officer or contractor after the service had been entered upon. This was passed after but little discussion. (Proceedings, vol. iv, p. 2777.) Railroads were forced to get the consent of the town or city officials before construction in cities or in incorporated villages, also the consent of property-owners of at least one-half the real estate value upon the line of the proposed railroad. All local or private bills were required to publish notices in the State paper at least twenty days previous to the commencement of the session at which the application was to be made. Such bills had to be introduced during the first sixty days of the session. Also the legislature was not to pass local or special laws in certain cases.

'Mcssages from the Goremors, vol. v, p. 758. He gave his reason that the increase in population with the resulting increase in crime, 
that a stringent limitation should be made on the executive's power to pardon. The committee interviewed ex-Governors Fish. Morgan and Seymour, as well as Governor Fenton.' The advice of all except ex-Governor Fish was against an executive council and the section on the pardoning power remained maltered.

A practice established by the Governors and sanctioned by the Court of Appeals, whereby the Governor had an indefinite length of time within which to act upon a bill after the adjournment of the legislature, was discussed by the convention. The leading suggestion offered upon this power cane from Mr. Cornelius L. Mllen. Governor Fenton, it appeared, had suggested that the time for signing bills be limited to thirty days after adjournment. ${ }^{2}$ The proposition for a ten days limitation suggested by Mr. Alvord, was rejected but the convention took no definite stand on the thirty-day rule. ${ }^{3}$

made the Governor unjustly over-burdened with the consideration of reprieves. He suggested no constructive plan. Horace Greeley suggested a plan in point, riz. "the surviving ex-Governors of this State still residing within her limits shall constitute a council of pardons and shall meet steadily at the capitol..." Procecdings and Debates, vol. ii, p. I 183 .

In its original report the committee did not incorporate this, but as the report was discussed, the provision was incorporated in a section of the exccutive article as reporter by the committee on rerision, Proceedings and Debates, vol. ii, p. I1 72 , vol. v, p. 3962.

1 Ibid., p. II72.

- Procedings and Debates, vol. ii, pp. II28, ir3I. Mr. Joshua M. Van Cott proposed as a substitute to Mr. Alvord's amendment that "No bill shall become a law unless it shall have been presented to the Governor at least ten days (Sundays excepted) before the adjournment... or signed by him before the adjournment, or unless it shall have been passed over his objection." This also was lost.

3 Governor Fenton's thirty-day limit was adopted by the commission of 1872 . An amendment was submitted and ratified by the people in 1874 . 
A radical change in connection with the veto power was proposed by the committee on the executive. It was suggested that the Governor might veto certain distinct and separate portions of any bill. In case of veto the whole bill was to be returned to the legislature and if repassed by the required two-thirds vote, it should become a law as if the entire bill had not been vetoed. But if the bill did not receive the necessary vote, then the part not vetoed was to be engrossed as a separate bill and returned to the Governor. Messrs. Evarts, Folger and Comstock came out strongly against the plan, while Amasa J. Parker sided with the committee. Mr. Folger objected that it would make the Governor an affirmative law-maker in that he could accept a portion of a measure. ${ }^{1}$ Mr. Parker maintained that it was simply an enlargement of the veto power. ${ }^{2}$ At length, after the consideration of a number of amendments, the convention, on Mr. Rumsey's motion voted 52 to $3 \mathrm{O}^{3}$ to retain the existing veto power.

\section{MISCELLANEOUS}

When the convention met the canal situation was replete with opportunities for reform. Two committees were appointed to report, one on canals proper, the other upon canals and State finance. The financial provisions, except those directly connected with the canals, underwent but slight change. ${ }^{+}$The committee on canals proposed the appointment of a superintendent of public works for eight years by the Governor and senate. He was to have four assistants, appointed upon his recommendation by the Governor and senate." Mr. Schoonmaker, Mr. Tappan and Mr.

1 Proceedings and Debates, op. cit., p. III2.

1 Ibid., p. II 7 .

3 Ibid., p. II24.

'Ibid., p. 812.

s Ibid., p. 813. 
Champlain presented a minority report. ${ }^{1}$ They dissented from the majority plan on the ground that it placed too much power in the hands of one man, and proposed four superintendents instead of one, with the canal divided into four sections, the superintendents to be elected by the people for eight years. The majority report was approved by the convention after it had been nodified by the reduction of the term fron eight years to five. ${ }^{2}$

In relation to canal contracts, $\mathrm{Mr}$. Erastus Brooks proposed an important amendment which was adopted by the convention." He referred to the provision in the amendment of $185+$ under which the lowest bids, by means of combination bids, woukd be fraudulently rejected for informality. He proposed that no bid could be rejected for informality till an opportunity had been given to the bidder for its correction. ${ }^{4}$ Further, under the Brooks amendment no specification could be changed before or after the execution of the contract without the consent of the commissioners of the canal fund and the superintendent of public works."

A large number of amendments were proposed and rejected, when the finance article was under consideration. which provided for the taxation of real and personal property. ${ }^{6}$ The requirement for a statement of property was

1 Proceedings and Debates, op. cit.. pp. 814-16.

-Ibid., vol. iii, p. 2056.

With the proviso that the contract systen might be discontinued and other methods of performing public works adopted.

- Proceedings and Debates, op. cit., p. $209 \mathrm{I}$

${ }^{5}$ Ibid.

- Among others, were those by:

Mr. George Rathbun, "Taxation upon the real estate and personal property in this state shall be equal on all such property liable to the payment of taxes." Proceedings and Debates, vol. iii. p. 2248.

Mr. Augustus F. Allen, Ibid., vol. iii, p. I900.

Mr. Angus McDonald, Ibid., vol. iii, p. 1982. 
omitted. However, the convention agreed to a section which in its final form read " real and personal property shall be subject to a uniform rule of assessment and taxation ".

Lnder the educational head no important changes were made. However, all of the important provisions concerning education which were adopted by the Constitutional Convention of $1894^{2}$ were thoroughly discussed in the conrention of $1867 .^{3}$

The ticle of legislative corruption, as well as that among

Mr. Solomon Townsend, Ibid., vol. iii, p. 2272.

Mr. Erastus Brooks, Ibid., vol. iii, p. 1982.

Mr. Marcus Bickford, Ibid., vol. iii, p. 1982. Property both redl and personal should be assessed at "full cash value."

Mr. John Stanton Gould, Ibid., vol. iii, p. 2339; He suggested a commission of three to investigate and prepare a system of taxation.

Mr. George Van Campen, Ibid., vol. v, p. 3496; He provided that all property, both real and personal, should be taxed "excepting such charitable purposes as may be specially exempt by law."

Mr. David Rumsey, Ibid., vol. iii, p. 1952.

Rerised Record of Constitutional Concention of I894, vol. v, doc. 62 , p. 695.

1 Procedings and Debates, vol. v, p. 3969.

- "The present constitution is silent upon the vital point of the establishment and maintenance of a system of free common schools. It may be urged that no imagination can picture this State refusing to provide education for its children and for this reason the declaration which your Committee have reported in Section i, might, no doubt be omitted without endangering the stability of our present system of education. But the same reasoning would apply to many other matters... and it is a significant fact that within the last half century of constitutional revision no other state of the Union has considered it superfluous or unwise to make such an affirmation in its fundamental law. Your committee, therefore, recommends the adoption of Section $i$, as an applied direction to the legislature to provide for a system of free common schools wherein all the children of the State may be educated."

- The provision regarding the common schools had once been adopted by the convention of 1846 but afterwards rejected. 
public officers, was at its flood during this period. The cominittee on official corruption took extensive testimony on the alleged bribery of members of the legislature, on which they based the report. ${ }^{1}$ Bribery of public officers was defined and provision made for its punishment by imprisonment for not less than three years. ${ }^{2}$ Satisfactory proof of innocence was to be the only avenue leading to a pardon or a commuted sentence when once convicted of bribery. A radical change in the law was proposed by the committee under which the briber, if the bribe was accepted, was not to be punished. The sole person guilty of a criminal offense was to be the bribee. An attempt at bribery was likewise made a felony, punishable in the same manner as the offense of receiving a bribe with this difference, that the briber was to be the person guilty of criminal offense. ${ }^{3}$ The committee believed that the only way to overcome the tendency toward bribery was to make one of the parties to the crime immune. They believed the briber was the less guilty of the two. The article as proposed by the convention of 1867 was recommended practically in toto by the commission of 1872 and the people adopted it in $187+{ }^{4}$

'Proceedings and Debates, vol. iii, pp. 2276-80; Concention Documents, vol. v, No. 150 . Testimony and Report. pp. I-51.

- Convention Documents, op. cit., p. 2.

'Ibid., sec. 2. "The person or persons giving such bribe, if the same shall be accepted. shall not be deemed guilty of a penal offense, nor liable to civil or criminal prosecution therefor. But any person who offers or promises such bribe if the same shall be rejected by the official to whom it is tendered, shall be deemed guilty of an attempt to bribe. which is hereby declared to be a felony, and on conviction shall receive the same measure of punishment as is provided in this article for a person convicted of receiving a bribe."

Sec. 3. "A person charged with receiving a bribe, or with offering or promising a bribe that is rejected, may be compelled to testify against himself in any civil or criminal prosecution therefor, . . . and the lapse of time shall not be a bar to any prosecution against him."

' Journal of the Constitutional Commission, 1872-3, pp. 50, 474. 
Under the direction of Erastus Brooks, state charities received exhaustive attention in the convention. ${ }^{1}$ The efforts spent in that direction bore fruit in the convention of $1894 .{ }^{2}$ The proposal of the committee was to make the State board of charities permanent by constitutional provision. The majority in the convention argued that the State board of charities, only recently created, was an experiment and that the legislature should be given the opportunity to reflect on it. This reflection was continued for twenty-seven years up to the convention of $1894 .^{3}$

Under the statute which called the convention, it was required to meet on the first Tuesday of June (4th). The constitution which was to result from its deliberation was to be submitted on November 5, I867, at the general election. The convention worked steadily through the summer. When in the latter part of September it became evident that the convention would not be able to complete its work in time for the election set, George William Curtis proposed that the convention should adjourn until November I 2 th. ${ }^{*}$ This proposition was debated at great length. Mr. Smith M. Weed favored arljournment until the first Tuesday of May, I868," nuaintaining that this would be necessary in order to allow the legislature time to pass an enabling act. Samuel J. Tilden cast doubt on the legality of a submission not under the statute. ${ }^{6}$ Mr. Joshia M. Van Cott believed that the power of the convention came from the people direct and not from the legislature. ${ }^{7}$ which,

1 Procecdings and Debates, vol. v, p. 3969.

'Ibid., vol. iii, pp. 2710-2793; Report, vol. ii, pp. I309-10.

'Rerised Record Const. Conv'., r894, vol. ii, pp. 948-949.

- Proceedings and Debates, vol, iii, p. 1955.

slbid., p. 1957.

6 Ibid., p. 1960.

'Ibid., p. Iç6r. 
therefore, had no power to limit the time of the convention. The resolution advanced by Mr. Curtis was passed by a vote of yo to $40{ }^{1}$

The committee on submission recommended on February 21. 1868, that the constitution be submitted in two parts, viz.: first. "The constitution, except the article on the judiciary": second, "The article on the judiciary". It also suggested the separate submission of the question whether the portion of the constitution of 1846 which imposed a property qualification on colored voters should be retained. ${ }^{3}$ The committee further believed that the convention had the power to fix the time for the submission of the constitution. ${ }^{4}$ Two propositions, one to submit the constitution at a special election in June. " the other to submit it to the legislature, were defeated. ${ }^{\circ}$ By a vote of 6 I to $3 \mathrm{I}$, the convention adopted the committee's recommendation to submit the constitution at the November election of $1868 .^{7}$ Several miscellaneous propositions for separate submission were defeated. The convention accepted the constitution by a vote of $8+$ to 3 I on February 28, I 868.

\section{RÉSUMÉ}

Mr. Folger, as chairman of a select committee cf ten, prepared an address to the people which may be cited as an excellent summary of the convention's work. The address was made the more valuable by the many alterations, cor-

1 Proccedings and Debates, vol. iii, p. 1969.

- Convention Documents, I868, vol. v, no. I80, p. I.

Ibid., p. 2.

- Conc'ention Documents, I868-69, vol. v, no. I80, p. 3. "Resolved: that this Convention has the power, and it is its duty, to fix the time for the submission of the Constitution."

- Williams, Proceedings and Debates, vol. v, pp. 3896, 3906.

- Ferry, ibid., p. 3906.

Tlbid., p. 3907 . 
rections and criticisms through which it passed in committee of the whole. ${ }^{1}$

The delegates of the people, in Convention assembled to revise and amend the constitution of the State, having ended their labors, present to the people for their adoption an amended constitution of fourteen articles. to be considered together.

They have presented for separate consideration, ${ }^{2}$ a paragraph relative to suffrage for colored persons. The rejection of this by the people will not effect the harmony of the whole instrument, and if adopteci, it will become a part of the constitution without and derangement of that ti which it is attached. In these fourteen articles, we have provicled for progress in agriculture, by requiring general laws giving the right of draining across adjoining lands.

We have provicled new and stringent provisions to stop bribery and improper influence at elections, and have required from each elector, upon challenge, to make oath that he is free from corrupt motive and practice, and we have provided in explicit terms for a registry of voters by laws to be uniform in all cities.

We have reorganized the Legislature, so that the terms of office of all the Senators shall not expire at the same time, thereby securing in that borly a new element of experience and stability, and to the end of greater capacity in the representative, have restored the plan of electing members of Assembly by counties.

We have increased the compensation of the members of the Legislature, as a means to their integrity, and increased their number to one hundred and thirty-nine as a step toward the prevention of controlling combinations.

We have, to stop abuses in the disposition of public money by law, placed important restrictions upon the exercise of

1 As quoted here the address is in its final form.

- Proceedings and Debates. vol. v. p. 9916. 
legislative powers; have confined it more to general legislation by positive inhibition upon the passage of special laws, and upon matters of local moment have provided for large power of legislation in boards of supervisors.

We have strengthened the veto power of the Governor by requiring a larger legislative vote to pass a bill in spite of his objections.

We have changed the time of the election of the Secretary of State, Comptroller, Attorney-General ani Treasurer, so that they shall be chosen at the same time with the Governor.

We have changed the system of the care and management of the canals by abolishing the offices of canal commissioners, and have discontinued certain boards and officers having direction of the canals, and have provided for an individual and substantial and single responsibility for official action in regard thereto, by creating one heari to the canal system, who is to be appointed by the Governor and Senate for five years, with large and important powers, and with the sole control of the canals, and with the sole and immediate responsibility for its exercise.

We have set guards against the making in wicked ways and for evil purposes, of contracts for the maintenance of the canals.

We have created a court of claims for the adjulication of all demant!s against the State, and taken away all the power of the Legislature to pass laws in relation to claims, thereby removing one prolific cause of frequent interested and sometimes improvident legislation; we have created a solicitor in this court to care for the interest of the State in the matters which come into this court: and we have abolished the office of canal appraiser.

We have materially changed the judicial system; we have made a permanent and efficient court of last resort of seven judges, to be elected for fourteen years, no elector to vote for more than five candidates; for a commission to dispose of the causes accumulated in the present Court of Appeals, thus relieving the suitors from the delay which is a denial of justice; 
for such an arrangement of the existing Supreme Court, as will restrict the number of general terms, thus securing less diversity of (ecision, and have extended the term of office of the Justices of the Supreme Court; we have made courts, by the Constitution, of the Superior Court of the City of New York, the Court of Common Pleas thereof, the Superior Court of Buffalo, and the city court of Brooklyn, continuing in office the present judges thereof, and lengthening the term of their successors to fourteen years, and increased the number of judges of the Court of Common Pleas of New York.

We have much enlarged the juristiction of the county court and extended the terms of office of the County Judge.

We have provided that no judge of the Court of Appeals or Superior Court shall sit in review of his decision, and forbidden certain julges from practising in courts and acting as referee.

We have provided for the relief of Surrogates' Courts in the counties of largest population ; and generally have increase! the working power of the courts, and by the extended terin of office have made more independent and permanent and useful the bench of the State.

We have also provided that, in 1873 , it shall be submitted to the people whether the judges of the higher courts of record shall be appointer! by the Governor, rather than elected by the people.

We have made new provisions in regard to the organization and government of cities, by increasing the power and responsibility of the Mayor, by preventing members of the common council from holding any other office, and any city officer from being a member of the Legislature; by providing for the organization of government of cities by general laws, and forbiclling special acts for such purposes, we have restrained the power of the common council of any city to dispose of public money.

We have continued the constitutional provision as to the funds for the purposes of education, making them inviolate: and have also made inviolate the fund arising from the sale of the land donated to the State by the general government. 
and the fund known as the Cornell University fund, and have commander legislative provision for free instruction in the conmmon schools of all between seven and twenty years of age.

We have materially changed the system of control of the State's prisons.

We have abolished the offices of inspectors thereof, and have made insteall an unpaid board of five persons to be appointed by the Governor and Senate for ten years; which board shall appoint the warden of each prison, who, in turn, shall appoint inis subordinates.

We have provided for an annual enrollment of the militia; for its division into an active and reserve force; for the formation of a national guard, not to exceed in time of peace thirty thousand men; for the election of brigadier-generals by field officers of brigades, for the expiration of all commissions in ten years from date, and for the organization of a reserve corps of officers to be composed by those retired at the end of ten years.

The financial article of the constitution of 1848 , with its salutary provisions of tried goodness, is in the main preserved but we have simplified its letter: and, led by its careful spirit, have provided that the State shall not in any way, save by bequest, own stock or shares in any corporation, or invest in the same.

We have authorized the extension of the time for the payment of the "hounty debt', so as to lessen the annual tax therefor, and to spread its burdens over a large space.

We have made provision for an carlier application of the revenues of the canals to their improvement.

We have requirer that there shall be a uniform and equal rule of assessment and taxation of real and personal estate.

Recognizing the strength of the public feeling, and deeply impressed thereby, we have made stringent provisions as to corruption in office, and as to bribery of officials; made practicable the trial and conviction of offenders; have put upon district attorneys the duty of prosecuting, under penalty for negligence, and have provided for the payment by the State 
of the expenses of prosecutors against a State or legislative official for bribery in office.

We have also enacted an oath for public officers as a guard against bribery at election.

These fourteen articles embrace all the provisions agreed upon in the Convention, and compose an entire constitution for the State. The discussion and conclusions of the Convention have not resulted in many or great changes in the theory of a State govermment, but have come principally to the amending of modes, the alteration of letails, the putting stops upon abuses, and the well working of the whole by easing friction in the parts.

The Convention has conceiver that as its amendments are numerous, affecting every article of the present Constitution, often dependent one upon the other, and together making a constitution, in the judgment of the Convention, complete and harmonious, it is not juclicious or practicable to take part from the others to be passerl upon by the people separately.

After the proposed constitution had gone through its hnal reading. the constitution was signed by the delegates present and was delivered by President IVheeler to the Hon. Homer A. Nelson. Secretary of State. President Wheeler in a brief but dignified address, the spirit of which was the hope "that our labors have not been altogether fruitless ", ${ }^{1}$ adjourned the convention sine dic. ${ }^{2}$

\section{Procecdings and Debates, vol. v, p. 3950.}

- This convention sat nine months, including adjournments. The convention of $1776-7$ sat a short time, only six weeks being devoted to the actual work of making a constitution. The present convention sat close to four, times as long as the convention of $\mathrm{I} 82 \mathrm{I}$, and was twice as long as that of 1846 . The convention of 1894 sat four months and three weeks. 


\section{SUBMISSION}

An attempt was made by the assembly of 1868 to pass a bill for the submission of the constitution at the November election for that year. This was blocked in the senate. However, in May the legislature passed an act which ratified the proceedings of the convention held beyond the time fixed for the submission of its acts to the people. ${ }^{1}$ The weight of opinion seems to hold that this ratification was unnecessary. Mr. Charles Z. Lincoln states: "I think it is very clear that the legislature had no power to limit the reliberations of a constitutional convention; such a convention may make or mmake the legislature itself." 2

Mr. Folger, continuing his senatorial activity in behalf of the convention's plan of submission, introduced a bill. early in 1869 , to submit the proposed constitution at a special election on Tuesday, April 4. I869. He incorporated the convention's plan for the submission of the contiuntion as a whole and the question of property qualifications for colored voters. Mr. Murphy of the senate judiciary committee, to which the bill had been referred, made a minority report and accompanied it with a bill which proposed the submission at the November election in 1869. also, that the article on the judiciary should be submitted separately. Before the bill became a law it was amended $s_{0}$ as to provide for the submission of the constitution in four parts: first, the complete constitution with the judiciary article; second, the article on the judiciary; third, the pro-

${ }^{1}$ Lazes of 1868 , ch. 538, May 2, 1868.

${ }^{3}$ Lincoln, Constitutional History of Neze York, vol. ii, p. 414. The legislature of I894 used a potent means to limit the length of the convention. It stated a definite period for which compensation would be due to members of the convention. This did not stop the convention of 1894 from continuing its labors over the time set. 
vision relating to taxes: and lastly, the qualifications for colored voters. ${ }^{1}$

The question naturally arises, what right did the legislature have to control the method of constitutional submission: While it is not within our province to discuss a question of constitutional ethics, it appeals to the author as another instance of the usurpation of power by the legislature. If. as appears clear, in the case of a constitutional convention. the legislature has no previous power to determine the method of a constitution's submission in part or whole, why should it have that power after the constitution had been formed? The New York State constitution provides for but two ways of constitutional amendment. ${ }^{2}$ First, the legislature is authorized to submit annendments, which require previous action by two legislatures. A constitutional convention, independent of the legislature, is the second mode of amendment. Where the latter mode of procedure has been decided upon by the people, why shoukl the legishature have power to step in and dissect the work of the convention on the question of submission? If such a nethod is good law, wherein have the people power to control the legislature? ${ }^{3}$

The recommendation of the convention for a separate submission was ignored by the legislature. This attitude on the part of the legislature might have been anticipated from the Act of May 2. I868 (Chap. 538) "Nothing herein contained shall be held or construed to affirm or ratify any form or mode of submission to the people of the Constitution by said Convention proposed."

${ }^{2}$ Nea York Constitution, art. xiv, secs. I-3.

${ }^{3}$ The New York State constitution as acted upon by the convention of I894 says: "Any proposerl constitution or constitutional amendment which shall have been adopted by such convention, shall be submitted to a vote of the electors of the State at the time and in the manner provided by such convention, at an election which shall be held not less than six weeks after the adjournment of such convention." Article xiv, sec. 2. 
is prescribed by statute, the people voted upon the constitution at the regular election November 2, I869. The judiciary article was approved by a vote of 247,240 to $240,442,{ }^{1}$ but the people rejected the constitution by a vote of 223.935 to $290,456 .^{2}$ The constitutional amendment providing for equal assessment and taxation was lost by a majority of $89,4+8,3$ as was equal negro suffrage by a vote of 249.802 to $282,403 .^{4}$ There can be no question of the chagrin to many members of the convention due to the large failure of their work. Still the fact that many of the most important reforms proposed by the convention were recommended by the conminssion of 1872 must have been a solace. The fact that the people in 1874 and 1876 chose many of the reforms suggested by the convention of 1867 gives evidence that their arrows were not aimed at the constitution as a whole.

\section{POLITICAL ASPECTS OF THE CONVENTION}

Politically. the constitutional convention and the proposed constitution exerted but slight influence upon conditions, in comparison with the political power brought to bear upon the convention. Its members were more "sinned against than sinning". The convention was theoretically a constitutional non-political body. Practically, however, it was a most deciderl political organization. This could hardly be otherwise in the nature of the case. As we have stated before, the political complexion of the convention

'Tribunc Almanac, 1870, p. 5 I.

Ibid.

'Ibid. For, I83,8I2: against, 273,260.

-Ibid., p. 53. In I860 the same proposition received the following vote: total vote. 535.487 ; for negro suffrage, I97.503, against negro suffrage. 337,984 . In 1846 the vote on the same question was: total rote, 309.742 ; for negro suffrage, 85,406 , against negro suffrage, 224,336 . Innual Cyc., 1869, p. 490. 
was Republican, ninety-seven of the one hundred-sixty delegates being Republican. However, there was a silent minority, which to the opposing leaders meant danger. Mr. Sanford E. Church was the Democratic leader most feared. In speaking upon the question of submission. Mr. M. I. Townsend said of him: "It is equally true that if matters shall stand as they now do, a breath from the great war-horse of the Democratic party, my friend from Orleans... might be sufficient to array his whole party against the other articles ${ }^{1}$ whether the submission be in June or in the fall." Mr. "Townsend then continues:

The other articles are doomed to defeat, hopelessly doomed. What do our Democratic friends mean here? What signifies this silence? 2 I do not hesitate to look at political distinctions; I want that we, as Republicans, should not be beguiled and led? into traps in regard to this matter. If our friends upon the Democratic side of the house want this Constitution adopter. they can say so: and when they say so, all question of conflict is past. ${ }^{3}$

1 All besides the judiciary article.

'New York Tribune. August 7, 1867. Mr. Greeley warned the Republican on this point. "It is no credit to the Republican majority that the minority have virtually ruled the Convention thus far. [By their absence.) Shall it be so to the end?

3 Albany Argus, Fel, 27, I868, after summing up the work of the Convention to late rather disagreed with the above: "The vast scheme of centralization and usurpation cannot be successful. if the people in the coming election wrest the power from the hands of the party who expect to profit by it. Place the Democracy in power by your votes, and these conspirators will hasten to undo their work. They will build up no lawless patronage, no vast schemes of expenditure... pile up no arbitrary powers in the hands of central officials or State boards. They will hasten to undo their work, will rather abandon it and leave it a monument of their baffled ambition, than permit it to exist as a means of strength to their adversaries." Under the title "A Copperhead Hiss," Harper's Weekly derived much amusement from the fury of the Albany Argus, the 
A number of the Republican leaders of the convention recognized the unpopularity of the proposed constitution. ${ }^{1}$ Mr. Hale, in his argument against a separate submission, said :

Suppose the Democratic party should make an issue upon any part of this Constitution and should wish to have the prestige of victory in June for the purpose of aiting them in Novenber, are they tempted by having the election in June to make that effort without regard to their opinion of the merits of this Constitution, for the sake of the effect which the prestige of victory would give them in November?

Mr. Verplanck, in speaking of the action of the convention giving the unrestricted right to vote to all the male inhabitants of the State over twenty-one years old, and the result of the Ohio election ${ }^{2}$ on the subject of negro suffrage. said, "These two facts have greatly contributed to make this convention unpopular with the people of the State." 3 Judge Comstock, of Syracuse, one of the minority leaders who replied for the minority, would not commit himself. He answered that it was "the duty of all of us, although

chief Copperhead organ in this State, over the recess of the Constitutional Convention. "It has been the fond hope of the amiable Argus from the moment that submission of the new Constitution at the election this autumn became evidently impossible, that it would go over until next autumn. When the Argus contemplates a separate submission of the instrument to the calm and unbiased popular judgment, it froths in the most comical manner." [Froth.] "Shameful and impotent conclusion. These men think that they can escape the people thus. They rely upon this juggle to cheat the people out of power, and to impose upon future generations a costly, arbitrary, centralized government against their will, without their consent, by the sleight of hand of a mountebank trick." Harper's Weekly, Oct. I2, I 867 , p. 642.

1 Proceedings and Debates, vol. v, p. 3903.

?Ibid., vol. v, p. 3904 .

${ }^{3}$ Ibid. 
we have sat here together in framing the constitution, to examine it carefully, as a whole, and say whether it ought to command our condemmation or approval." '

The majority party early in the course of the convention found another powerful foe within its own ranks. Horace Greeley, who was a nember of the convention, soon grew restless under the routine. The frequent lack of quorum and general irregular attendance annoyed him. He vigorously opposed the Fridlay to Tuesday adjournment. ${ }^{2}$ It was his belief that the convention should work hard and finish the revision at an early date. He spoke often, but presently lost the power to influence his fellows. Then he turned to the Tribume as an outlet for his views and feelings. The Tribune with its constant biting renarks led the sentiment of the lesser Republican papers, which harmed the work of the convention to an incalculable degree. ${ }^{3}$

Proccedings and Debatcs, op. cit., p. 3905. With the exception of the Tribune and the Dispatch, all the daily and weekly newspapers published in New York City were virtually arrayed against the Constitution.

"Proccedings and Debates, vol. i, p. I64; vol. iii, pp. I958-9. Greeley made a practice of reporting the names of the absentees in the Tribune. We find the following characteristic note at the foot of his convention report for September 7,1867 : "A party of ten or twelve delegates, headed by the Secretary of the Convention, Major Caldwell, last nigh started for Boston for a few days of Mackerel fishing."

8 The following extracts may be taken as typical of the almost constant growlings of the Tribune at the sloth of the convention, as well as the necessity of the people to constantly waich its proceedings and to inform the convention of the public sentiment upon questions of weight. In the Tribune, August I, 1867. Greeley eagerly prepared the minds of the people for an unsatisfactory settlement of the judiciary question: "If we are to be believe the reports from the Constitutional Convention... there is but little hope for a thorough reform of our judicial system." "We again ask the Citizen's Association why it remains quiescent at this critical time. It has in a languid way asserted the necessity of change; but it has not collected and published 
When the convention adjourned on September $24^{\text {th }}$ until November I 2 th. the Democrats at once were strident in their accusations. The IVorld could not conceal its rleligint. ${ }^{1}$

the facts which would convince the mass of honest citizens of that necessity." On August 7th (Tribune, August 7. 1867), in speaking of the eight weeks of actual session from June 4 th, Greeley says: "Of the other eight, a considerable portion of each have been lost through adjournments from Friday to the succeeding Monday. At the hour appointed for assembling, no quorum appears; so that day is wasted in awaiting or more actively seeking to obtain one. If the Convention declines to adjourn over when asked, a large portion of the members take French leave, and return when convenient... Members gravely rise in their places and ask that a decision on the pending question be postponed hecause $A, H$, and $C$ are ahsent, who desire to speak or rote thereon. .

What right have these or have the incumbents of other offices requiring frequent personal attendance at points remote from Albany to accept nominations to seats in the Convention? Why not frankly say. I have duties or tastes which are incompatible with faithful serrice as delegate. Would not this have been wiser and worthier than to undertake responsibilities so grave with purposes or obligations so incongruous."

In justice to Greeley it must be said that he violently defended the majority from the Democrat attacks. He gave the minority "full faith and credit" for its share in the non-productiveness of the convention. Further, in the campaign of 1867 , Greeley consistently maintained the Radical doctrine of equal suffrage for negroes. The Herald of Sept. 28, I867 remarks: "While Greeley proposes to fight through this fall campaign on the paramount issue of the "almighty nigger', and to drop all side issues, Senator Conkling proposes to sink all the great issues of the day in the little side issues of Andrew Johnson. Gentlemen, which is your ticket, Mr. Johnson, or Pompey?"

1 New York Iforld. September 26, 1867: "The adjournment to the 12th of November is a skulking subterfuge to avoid an open confession of failure... When the Convention meets on the 12 th of November, it will be as destitute of any legal authority as a caucus. ... In the farce which follows this well-hissed play, the Republicans will resort to all sorts of dodges and expedients.... If the Republicans are really in favor of negro suffrage, ... why did they refuse to submit it as a Constitutional amendment?" "The skulking out of the Convention project will cover the Republican party with derision."

Then in a gentle spirit of humility the World adds: "The Demo- 
The Herald was uncompromising in its criticism of the majority. ${ }^{1}$

For this, as for the whole work of the Convention since its organization, the Republican majority are responsible. . . . If the whole of the Democratic nembers had absented themselves from their seats from the first day of the Convention, the Republicans, if faithful in their attendance, could have completed their work in time for the next general election. There is no possibility, therefore, for the party of the majority to evade the responsibility for the disgraceful failure of the Convention, and that failure can be attributed only to one of two causes-incompetency or dishonesty.

The Vation $^{2}$ in a calm, judicious article admitted that "everybody is more or less disappointed both with what the convention has accomplished and with what it promises. It has not dealt boldly with any of the abuses it was expected to remedy." This failure on the part of the Radical majority to bring the convention to a close in time for submission at the regular November election was attributed to cowardice. The Democrats maintained that the recess was taken to avoid a confession of failure. Further, the majority was accused of taking this method to evade bringing the question of negro suffrage to a vote at the next election. The failure of the majority to bring the burning question of negro suffrage to a vote caused it to be the object of ridicule. to all appearances rightfully deserved. To attempt the reconciliation of the convention's resolutions for " im-

cratic party has reason to be thankful that these odious schemes of mis-rule have miscarried, and that the total net result of the Convention is a new weapon to be used against the Republicans. Let it be brandished in their faces. Let it be thrust into their entrails. Let them be smitten with it 'hip and thigh.'"

${ }^{1}$ New York Herald, September 26, 1867.

- The Nation, October 3. I867, p. 274. 
partial suffrage " ${ }^{1}$ with its action seems to emphasize the truth of the Democratic position. The fact that the convention was under the absolute control of the Radicals warrants the assumption that they might have finished their work in the early autumn. Even the New York Times ${ }^{2}$ could not refrain from uttering a lament:

It is impossible not to feel that the Constitutional Convention thus far is a failure. It has done nothing of the things expected from it, nor has it shown any courage or energy in grappling with the various reforms which we demancied for the public good. Its action has been timid, halting and utterly indecisive.

Another stumbling-block was in store for the Republican party on the question of negro suffrage. The fact that their State convention, held at Syracuse on September 25. 1867 . had incorporated in their platform a plank" which approved the action of Congress on March 2, I867, forcing negro suffrage upon the Southern States, was a severe handicap. ${ }^{4}$ " The negro suffrage resolve of the con-

'Proceedings and Debates, vol. v, p. 3597. Art. ii, sec. I : "Every male inhabitant of the age of twenty-one years who shall have been a citizen for ten days and a resident of the State for one year next preceding an election, and for the last four months a resident of the county where he may offer his vote, shall be entitled to vote ... provided that such citizen shall have been for thirty days next preceding the election a resident of the town or ward, and for ten days of the election district in which he offers his vote."

- New York Times, September 26, 1867.

" "Resolved: That, as Republicans of the State of New York recognizing the obligation of consistency and straight-forwardness in support of the great principles we profess, we unhesitatingly declare that suffrage should be impartial, that it is a right not to be limited by property or color." Annual Cyc., 1867. p. 543.

"New York Herald, Sept. 27, 1867. James Gordon Bennett spoke of the Radical platform as a "sneaking, diluted, cowardly, fraudulent affair" and its treatment of the negro suffrage question, as well as other questions, as "timid" and "gingerly." 
vention is also an apology which accuses the party that makes it." " "The Republicans claim to be a majority in the State; and if they are, they could have conferred suffrage on negroes in this election, if they had chosen. What a barefaced sham it is to make a barren resolve in favor of black suffrage, instead of submitting it to the people and establishing it. If you are in favor of negro suffrage, why not confer it at once? How can you blame the South for hesitating when you hesitate? If you shrink from giving the ballot to a few thousand negroes at home, why do you insist that it should be conferred on millions in the South ?", These questions put by the $W$ orld are representative of the arguments used by the various Democratic papers.

The Nation attributed the lack of success in the convention proceedings to two main causes: the agitation in Federal politics, and "the indifference of the public to all its doings."

The proceedings of the Constitutional Convention of this State furnish a remarkable illustration of the injurious effects upon the work of local reform of the agitation now raging in Ferleral politics. ... The confusing influence upon it of Federal politics has been well illustrated in its action on the suffrage question. . . The Convention has not been called together to help in the diffusion through the Union of equal rights. It has been called to remedy the defects in the government of the State of New York; and the imposition of a property qualification on colored persons, though an important defect, was by no means the most important of the defects. It has been put in the first place, and taken up most time, simply because of its bearing on the course of reconstruction at the

1 New York World, September 27, 1867.

- New York Times, September 25. 1867. The Times thought that the convention could have at least made a separate submission at the fall election on the question of suffrage. 
South. The Democrats opposed it not because they anticipate any mischief from the removal of an odious discrimination against a few hundred citizens, but because they fear the influence of the change on the conflict between privilege ant Democracy at the South. The Republicans support it not because they fear the property qualification to be a grievous burden to the negroes, or because they feel that its removal will be any sensible benefit to the state, but because its maintenance would tell against their cause at Washington. ${ }^{1}$

The up-State papers of the Radicals gave daily attention to the movements in the constitutional convention, ${ }^{2}$ and in so far as they noticel the Democratic attacks upon its failure to face the issue of negro suffrage, the belief was comfortably expressed that the legislature would legitimatize the convention upon reconvening. ${ }^{3}$ The Buffalo Express attempted to minimize the Democratic attacks by disclosing the consistent endeavors of the Democratic minority in the convention to obstruct the work of the majority. ${ }^{*}$ The Democratic journals up-State claimed that the constitutional convention was a failure in every respect, ${ }^{5}$ and that it had legally ceased to exist. ${ }^{6}$ The Buffalo Daily Courier recommended that the Radicals" plan for the bridging over of an election be patented. " "Too weak to live and too infirm to die, it refuses to adjourn," said the Argus. ${ }^{8}$ " and yet is incapable of meeting ".

1 The Nation. October 3, 1867 , p. 274.

- Buffalo Express gave the fullest account.

Syracuse Daily Journal. Sept. 25, 28, 1867.

- Buffalo Express, Sept. 28, 1867.

- Rochester Daily Inion and Adzertiser. Sept. 24, 1867.

- Utica Daily Observer. Sept. 25, 1867.

'Buffalo Daily Courier, Sept. 25, 1867.

- Albany Argus, Sept. 25, I867. 
The revised constitution was the center of attach in the campaign of I869. The fact that the Republicans had controlled the convention and had insisted upon a negro suffrage clause. determined the Democrats upon its defeat. The keynote was given to the campaign when the Democratic State Convention ${ }^{1}$ at Syracuse declared that

the amended Constitution of this State in its various schedules to be submitted to the electors does not commend itself to the favor of the Democrats of the State, either by the motives in which it was conceived, or by the manner in which it was presented, or its intrinsic worth.."

There appears to be little question that the concentrated power of a great political organism was sufficient to defeat the constitution. It is to be remembered that the influence of the Democrats in this State was in the ascendant at this time. The constitution suffered defeat by a majority of 66.521 votes. $^{3}$ The majority of the Democrats for that year on the votes for State officers was over 20,000. The total vote cast for the office of secretary of state was I27,$316^{4}$ more than that cast for the constitution. These figures would seem to show that the vote on the constitution was not entirely on party lines. In their State platform for I 869 the Republicans were given small light to follow in regard to the constitution, no reference being made to it.

We may state, by way of summary, certain of the more powerful causes that operated to effect the defeat of the

${ }^{1}$ Held at Syracuse, September 22, 1869.

- Annual Cyc., r869. p. 488.

- Tribune Almanac, 1870, p. 51.

- Ibid. Secretary of State, Dem. 330,974

Rep. $\quad 310,733$

On the Constitution.

Against 290,456

For 223.935

Total

641,707

514,391 
constitution. The constitutional convention at best was never popular being always regarded by the people with a degree of suspicion. This unrest was intensified by the criticisns of Horace Greeley, who attempted to stem the tide too late. The canal frauds which were being disclosed at this time presented an unguarded flank for attack upon Republican dognua. 'The Radicals' policy of reconstruction lost many votes. Then, doubtless, many of the propositions proposed by the convention were too advanced for the people at large at that time. The more important points have since been incorporated in our constitution and time has shown the minportance of others, which have consequently been dropped. Two causes, however, appear to rank above all others as contributory to the overthrow of the proposed constitution. First, the Republicans during and after the convention failed to seize the earliest opportmity to show the sincerity of their purpose as to negro sulfrage. Secondly, and more important still, the Democrats muler the direction of the Tweed ring, which at this time held New York City in a grip of iron and was extending its influence up-State, were united against it. Naturally, the ring had no wish to foster changes potentially ininical to its rule. Lastly, it is altogether significant that independent Republican thinkers themselves aided in the constitution's downfall. 


\section{CHAPTER $\mathrm{X}$}

The Alliance of Wall Street and the Legislature

The political history of New York State for the year 1868 would be incomplete without a treatment of the "Erie Railroad War", which involved the economic and political foundations of the State. Millions were toyed with in Wall Street strategy which caused stagnation in the country's transportation, with a consequent suffering among the working class; the judicial ermine was disgraced and the legislative honor of the State made a mockery. The close relation between the Erie and the politics of the State will appear as the story unfolds.

Up to the time of the transformation of the New York and Erie into the Erie Railroad, the former had expended $\$ 35.320,907$ in construction and equipment. ${ }^{1}$ At the period we treat in this chapter, the ontlay had increased to $\$ 50,000,000$, the trackage had expanded into 773

'Mott, Between the Ocean and the Lakes; the Story of the Erie (New York, I899), p. I 36.

New York and Erie.

Its capital stock in fund was............. \$I $1,000,000$

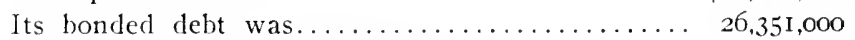

Its existing floating debt, I 860 , was.......... $2,725,620$

It had earned during the 19 years of its operative existence ............................. 51,098,106

At a total operating expense of............ 32,346,029

Leaving its net earnings for the 19 years....... $18,752,077$

And dividends had been paid to the amount of... $3.48 \mathrm{I}, 405$

While interests on the bonds and drafts on the treasury had absorbed .............. 15,270,672 267] 
miles, while the annual revenue had grown to the huge sum of $\$ 16,500,000$. This enterprise was one which appeared to present no mean opportunity for an unscrupulous man or men to use for purposes of self-aggrandizement. Much fairer would the name of Erie have appeared in times past had it escaped its designing friends.'

Chief among these we find at the period of our chapter two central figures, Daniel Drew and Cornelius Vanderbilt, with a third, Jay Gould, soon to out-top the former two. Daniel Drew, then in his seventy-first year, had been and was a man to be reckoned with in Wall Street. His first appearance in the board of directors of the Erie had taken place fifteen years previous. ${ }^{2}$ Drew had early turned his attention to the steamboat interest, where he had built up a fortune. In character he was a peculiar combination of good and evil, with the latter in predominance. He was superstitious, yet faithless; illiterate. shrewd. unscrupulous, yet timid.

Cornelius Vanderbilt, sometime ally and opponent of Drew, has a similar history. Vanderbilt was three years Drew's elder, and had origin also in humble circumstances. While Drew had driven cattle into New York City as a boy, Vanderbilt ferried passengers and merchandise between Staten Island and New York. Vanderbilt had built up a greater fortune than Drew in the steamboat industry. ${ }^{3}$ Both men were equally illiterate, unscrupulous and selfish. Their main point of difference, however, was one of temperament. Drew was sombre, while Vanderbilt was buoyant. hence an explanation of the former's bearish

${ }^{1}$ Cf., Ellis Paxson Oberholtzer, Jay Cooke-Financier of the Civil War (Philadelphia, 1907), vol. ii, p. I ct seq.

- Charles Francis Adams, Chapters of Erie (Boston, 1871), p. 5.

3 See Life of Cornelius I anderbilt-Parton. Famous Americans (Boston, r867), pp. 375-9o. 
tendencies and the latter's uniform operations as a bull in Wall Street. Time has given the two men their relative niche in history. Cndoubtedly Vanderbilt was the larger man, certainly in his conception of such an ultimate railroad system as to-day binds a large portion of the continent and honors his name. ${ }^{1}$ Drew had no other apparent conception than to use the Erie for the furtherance of his own personal ends.

For our purpose the prelude to the war of I 868 began with the Erie raid of $1865 . .^{2}$ The story may be told concisely. Erie was quoted on the market in the early part of I 866 at 97." The bete noir of the Erie, i. e., its floating debt was ever present. The Erie needed money. Drew most opportunely had money to lend it-upon security. He proposed to loan the company $\$ 3,480,000$ for two years at seven per cent, on 28,000 shares of stock, or $\$ 3,000,000$ convertible bonds at sixty per cent as collateral. ${ }^{*}$ There was to be no margin of depreciation and the loan was payable as wanted at any time within four months. The company conld retain all dividends and pay off the loan or any portion of it on ten days' notice. The company accepted the offer. Drew, in addition, was equipped with IO,OOO shares of stock placed at his disposal, which the company had obtained through using the law which empowered any company to issue its own stock in exchange for another company's, the property of which was under lease to it. ${ }^{5}$

1 Adams, op. cit., pp. IO-II.

- There were two laws which gave Drew opportunity to execute his masterpiece in high finance. Vide Laz's of New York. I86I, Ch. II9. pp. 213-15; Laws of Vew York. 1850, Ch. 140, pp. 211-35.

${ }^{3}$ Cf., New York Herald, Jan. 7, I866-Erie, 961/3; Jan. 8, I866Erie, 961/2; Jan. 8, 1866-Erie, 961/2: Jan. 4, 1866-Erie. 97; Jan. 3, I 866 -Erie, $97 \% 3 \%$.

- Senate Documents, I868, vol. v, no. 67. Sched. A., pp. 32-3.

- Mott, op. cit.. p. 142 . 
On January 6, I866, the Buffalo, Bradford and Pittsburgh Railroad ${ }^{1}$ had been leased to the Erie for a term of four hundred and ninety-nine years. This lease under the above law, placed at Drew's convenience stock capable of being transformed into Erie stock in time of need.

The time was ripe for Drew's harvest. Cornelius Vanderbilt was endeavoring to obtain possession of the Erie through stock purchase and to cripple Drew by a strong bu1l movement in Wall Street. Drew aided in his rival's expected coup. He contracted heavily to deliver on a certain day Erie stock at the existing quotation $97 .^{2}$ The fact that Drew appeared short of Erie, in conjunction with Vanderbilt's bull movement, made Erie buoyant. Speculation was rife. The leading question was, where would Drew obtain his stock to fulfil his contracts. On the appointed day his source of supply suddenly appeared. Drew simply transformed into an equivalent amount of capital stock the \$3.000.000 issue of convertible Erie bonds, and fifty-eight housand shares of stock were suddenly thrown on WVall street. The bulls were caught; before they could rally, the market price had fallen to fifty. ${ }^{3}$ Cornelius Vanderbilt was the chief loser in this légerdemain-a fact that Drew was forced to recall thereafter. This transaction, no more nor less creditable than the usual IVall Street gamble with loaded dice, was looked upon at that time as one of the great successes in the history of the Stock Exchange.

In I 867 , after rejuvenating the Harlem, Vanderbilt added to his possessions those roads which now constitute the New York Central system. Still nursing the wound received from Drew the year previous, Vanderbilt turned

1 Vide testimony of J. C. Bancroft Davis, Senate Documents, 1858, vol. v, no. 67 , pp. 68-8I; also ride lease of the Buffalo, Bradford and Pitsburgh Railroad, Ibid., Sched. B., pp. 34-40.

' Mott, op. cit., p. Ifi.

3 Adams, op. cit.. p. 7. 
his eyes toward the Erie. Through the aid of the Boston interests, who were exploiting the Boston, Hartford and Erie, Vanderbilt was enabled to obtain the election of John S. Eldridge, as presicient of the Erie, the election of Frank Work, a protégé of Vanderbilt's, to a seat in the board, and the defeat of Daniel Drew as director. ${ }^{1}$

It the election in which Drew suffered defeat, two new figures were added to the board, Jay Gould and James Fisk, Jr., both practically n1nknown outside of Wall Street. ${ }^{2}$ However. they were not destined to remain long in oblivion. Jay Gould, also, came from low surroundings. Born a poor boy and early left an orphan in the western part of New York State, he became a clerk in a country store, learned bookkeeping meanwhile, became a surveyor in a sirvey of his county, bought ont the map firm, then wrote a history of the county to go with the map, by selling which he made his first $\$ \mathrm{I}, \mathrm{OOO}$, all before he was twenty-one vears of age. At this time a man with a tannery in Pennsylvania took Gonld into partnership. Gould knew nothing about the business at the start but in three years had bought out his partner. His first acquaintance with New York was made throngh his visits to the City in order to deal with the wholesale buyers direct, thus avoiding the middleman's profits. He soon saw that there were more ways to accumulate money in New York City, than in the tanning business." "Jim "Fisk, as he was called, was a shrewd oper-

'Senate Documcuts, I868, vol. v, no. 67, pp. 42-3; New York Herald, Oct. 9, I0, 1867. One Underwood, a Vanderbilt supporter in the directory, resigned immediately and Drew's election to the vacancy was followed by his appointment to his old post as treasurer. This move caused great wonderment and uneasiness.

- See papers at elections Oct. 8, I867: New York Times, Oct. Io, I857; New York Herald, Oct. I0, I867.

3 James Parton, Men of Progress (Cincinnati, 1670), passin. Stephen Fiske, Off-Hand Portraits of Prominent New Yorkcrs (New York, I884), PP. I51-3. 
atur un the Street, though not of Gould's calibre. He was a bon zirant, indulging in all forms of excess. ${ }^{1}$

An interlude in open hostilities occurred, which lasted for nearly half a year. However, Vanderbilt was but gathering strength to renew his attack on the Erie strongholds. Vanderbilt reopened hostilities on February i7, I868. ${ }^{2} \mathrm{Mr}$. Frank Work, the sole remaining director under the Vanderbilt intluence, applied through his attorneys. Rapallo and Spencer, for an injunction before Judge Barnard, of the New York Supreme Court." This injunction was to restrain the board of directors of the Erie from paying the principal or interest on the money borrowed from Drew as treasurer in I866. Drew was restrained from bringing any action to compel settlement and the company likewise from releasing him from any of his obligations. A temporary injunction, as customary, was granted, with a further hearing assigned for February 2 ist. ${ }^{4}$ Vanderbilt's apparent motives for this move were, first to annoy Drew, and second. to act as a cover for his own designs in Erie. ${ }^{5}$ Withont waiting for the 2 Ist, Vanderbilt made another assault upon the Erie. Through Attorney-General Marshall B. Champlain, he petitioned before Judge Barnard ${ }^{3}$ for

${ }^{1}$ Carl Hovey. The Life Story of I. Pierpont Morgan (New York, I9II), pp. 53-4.

'Vanderbilt's ire was aroused by Drew's infringement on a cherished plan of Vanderbilt's, through an agreement with the Michigan Southern and Northern Indiana Railroad Company giving Drew a broad gauge line to Chicago. See New York Times. Mar. II, i867: New York Sun. Mar. II, I867.

- New York Herald, Feb. I8, I867.

- Ibid., Feb. 22. I867.

- Mott, Story of Erie, 148.

- The feasibility of Judge Barnard, as a potent ally had been early recognized by the various railroad interests, as well as by Tweed and Company. 
Daniel Drew's removal from the office of treasurer. The alleged cause for the renoval was that Mr. Drew and his associates had possessed themselves of a worthless road, in which they were the chief stockholders, then hat procured the issue of a large amount of Erie stock, which they had exchanged for the stock of the subsidiary road.

Justice Barnard temporarily suspended Drew from his position as treasurer and director and ordered him to show cause why the prayer of the petitioner should not be granted on the 21 st. On March 3 rd, Justice Barnard issued an injunction which restrained the defendants from the issue of any new capital stock other than the 241,058 shares previously appearing in the company's reports, or any further conversion of bonds into stock, or the guaranteeing of any connecting road." Further, Drew was orlered to restore to the Erie company the 58,000 shares of stock which he had recenved in May. I866, and the I0,000 shares acquired in exchange for the Buffalo, Bradford and Pittsburgh bonds. ${ }^{2}$

To the initiated it appeared that the leader of the bears had been bound hand and foot. If the law had any value, how could it be otherwise? But, injunctions had little apparent effect on Daniel Drew. He continued short in Eirie in the face of a rising market. Converting $\$ 5,000,000$ of bonds into Erie stock he flooded the Street. One hundred thousand shares of Erie were absorbed in less than two

1 The Buffalo, Bradford and Pittsburg Railroad.

- New York Herald, Mar. 4. 5, 1867.

- Mott, op. cit., p. 149. Cf. William Swinton, How the Ring ran Pacific Mail: a story of I'Tall Street (New York, 1867), passion.

- In stock exchange parlance an operator is short when he has sold that of which he is not possessed. He gambles on a fall. 
weeks, for which $\$ 7,000,000$ was paid. ${ }^{1}$ This, in addition to the 58,000 shares which Drew issued in 1866 , were chiefly absorbed by the Vanderbilt interests. The demoralization caused the Stock Exchange to take action against the Erie. It was ordered that no certificates of Erie stock dated after March 7 th should be honored. This order produced an effect in striking contrast to the mandates of the court.

March Ioth, the day set for the return of the writ was the day expected for a corner. But Drew surprised his antagonists before that. Drew knew the advantage to himself of the co-ordinate jurisdiction of the thirty-three judges of the Supreme Court. An order was obtained by his counsel from Justice Ransom Balcom, of Binghamton, which suspended Frank Work from the Erie directory, on the allegation that his acts were injurious to the company. ${ }^{2}$ .11 parties to the proceedings previously instituted were ordered to appear before Justice Balcom at Cortlandville, N. $Y$.. on March 7 th. $\quad \therefore$ ll other proceedings were ordered to be staid." When this order became known, another compiication arose in the legal tangle. The Vanderbilt interest immediately instituted a new suit before Justice George G. Barnard, of the Supreme Court in New York City, in the name of Richard Schell. ${ }^{4} \therefore$ order was issued which enjoined the Erie directors from meeting or transacting business unless Director Work was present with unrestricted powers.

The battle was now approaching the crisis. Commodore Vanderbilt hat a consuming desire for Erie stock, and

${ }^{1}$ New York Sun, Mar. 6-19, I868; New York Times, Mar. 8-20, 1868.

${ }^{2}$ New York Herald, Mar. 6, 1868.

'Adams, Chapters of Eric, p. 23. New York Herald, Mar. 6, 1868.

'Adams, op. cit., p. 25. 
Daniel Drew most charitably decided to satisfy his craving. At a previous meeting of the board of directors held February 19 , IS68, an optimistic account of the road's condition had been issued by the general superintendent and made public. ${ }^{1}$ On the adjournment of this meeting, the executive committee ${ }^{2}$ had met, with the result that it was voted to issue $\$ 10,000,000$ worth of convertible bonds. Five nillions were inmediately placed on the market; ${ }^{3}$ the executive committee having resolved to sell these bonds at not less than $72 \frac{1}{2}$. As the company could not issue stock outright at less than par, and as its bonds bore interest, hence were useless for Street operation, the issue of convertible bonds was Drew's sole resource. In a few minutes from the adjournment of the executive committee, Mr. Daniel Drew's broker, having been guaranteed against loss, had purchased the issue of $\$ 5,000,000$ and had housed 50,000 shares in his safe, to be used at Drew's bidding. These were distributed on February 29th to various of Drew's brokers. When the Barnard injunction spoken of was issued three days later, with the consequent rise in Erie stock, the other $\$ 5,000,000$ were suddenly launched upon the unsuspecting market. ${ }^{4}$

Before these bonds had been converted, Barnard's injunction was served upon the chief operators of the Erie. Service was returnable on March Ioth. However, the Erie

${ }^{1}$ New York Herald, Mar. 5, 1868.

2 At this meeting the board had clothed the executive committee with full power for the welfare of the road to issue new stock, which was done in all to the extent of 450,000 shares. The wording was vague. Senate Documents, i868, vol. v, no. 67, pp. 75-6.

${ }^{3}$ Senate Documents, I868, vol. v, no. 67, pp. 75-6. The executive committee had met in two sessions, one at noon, the other later in the afternoon. It was between these sessions that the $\$ 5,000,000$ of convertible bonds were sold to David Groesbeck \& Co.

‘ New York Herald, Mar. I, I868. 
chieftains decided to break the threatened " corner " on the 9th. Saturday night, of the 7 th, Mr. Ciroesbeck, one of Drew's companions-at-arms, secured a tool to act as producer of the bonds and took him to the home of the Erie

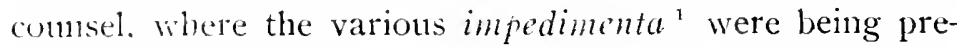
pared for the bewilderment of Vanderbilt. A contract of sale for the bonds was agreed upon and drawn up, which transferred the bonds to the nominal purchaser, who gave Drew power of attorney to dispose of the bonds as he saw fit, through a promissory note for the purchase money. At the close of the deal, a demand was made for the conversion of the bonds into stocks by the Erie, as per contract, which of course was refused. The purchaser then made afficlavit to the effect that demand had been made for the stock and refused. This affidavit had been previously prepared for the proper signatures. The intention at the base of this act was to seek a proper justice and obtain a writ of mandamus to compel the Erie to convert its bonds into stock. The evening's work was then ended. all papers were ready, the bonds had been arranged for, and the certificates of stock signed in blank, were ready for delivery." The mine was prepared.

The Monday following found the drama rapidly advancing. Iim Fisk seized from a messenger and made off with the 50,000 shares of stock, which Treasurer Drew had agreed to sell to the Messrs. Fisk and Gould at eighty, but which the secretary had been enjoined from issuing. These

1 Affidavits. New prayers for Writs and Injunctions. The vicepresident was signing certificates of stock in the event that a modification of the injunction should be obtained.

- Senate Documents, I868, vol. v, No. 67, pp. 87-8. Vice-President Alexander L. Diven spent Saturday night, even breaking the Sabbath. in signing certificates of stock at his home. Be that is it may, he disclaimed knowledge that they were to be used for the issue of new stock. 
certificates next received the light of day in Wall Street. Meanwhile it was thought advisable on the part of the Erie co-adjutors to further attempt the encloakment of their enterprise under the robes of the law. After an unsuccessful attempt to obtain a zerit of mandamus from Judge Gilbert of the Second Judicial District, the Erie counsel were successful in obtaining from the same judge an injunction in the name of Mr. Belden, Fisk's partner. ${ }^{1}$ The petition set forth the claim that Justice George G. Barnard in conjunction with certain others had entered into a conspiracy to use the courts to aid in their speculation in Erie stocks. Apparently, Judge Gilbert, who was an eminently respected jurist, was able to believe anything of his Manhattan colleague. His injunction restrained all parties, to suits then pending, from further action in any direction. This brought the matter from a legal viewpoint to a complete stop. To move, or not to move, in either case violated the injunction of one or the other court. The strategic situation could not have been more favorably conceived to suit Daniel Drew.

Fifty thousand shares of Erie stock were hurled into the market, before a new injunction could be obtained from Justice Barnard. The Vanderbilt agents unsuspectingly purchased these with avidity, the price rising from eighty to eighty-three. When the truth became known on the appearance of fresh certificates, the price suddenly dropped to seventy-one. ${ }^{2}$ At the close of the market for the day the Erie quotations read seventy-eight. Drew had won the battle, for it was erident that the Vanderbilt corner had failed. The question was, would Vanderbilt be able to sus-

1 New York Herald, Mar. 12, 1868.

2 Aclams, op. cit., p. 29: New York Times, Mar. II. I868: New York Sin. Mar. 11, 1868 . 
tain his loss. This he did, thus preventing a financial panic which would have carried him with it. The irony of the situation must have presented itself to Vanderbilt. Instead of crushing his opponent, the latter retired to New Jersey on the next day supplied with seven million dollars of Vanderbilt's currency. ${ }^{1}$ The retreat to Jersey City was precipitated on the morning of the IIth by advance intelligence that orders for arrest had been issued against Erie directors, that their only safety lay in flight. A headlong dash for the Jersey City ferry ensued, bales of money and valuable papers were hurriedly seized and deported. Some wa1ted until nightfall to cross in rowboats. In all only two directors were apprehended, and business was continued by a majority of the executive committee at the Erie station in Jersey City. ${ }^{2}$

The litigation begun in the New York courts was prolific with bizarre entanglements until both sides agreed to an injunction of universal application. Judge Gilbert soon passed out of the fray. He refused to renew his injunction, which had done its work. ${ }^{3}$ However, Judge Barnard exercised his prerogatives to the last. On one occasion he sent all the papers which related to the conspiracy alleged in the Gilbert document, to the grand jury, which refused to admit jurisdiction in such a matter. Again, he attempted to clean himself of taint by a series of counter-affidavits.

1 Adams, op. cit., p. 3I; New York Times, Mar. I I. I2, I868: New York Sun, Mar. II, I2, I868.

* The dingy hotel near the Erie Station where the exiles made their headquarters, was dubbed "Fort Taylor." New York Herald, Mar. 15, 16, I8, 19, I868; New York Times, Mar. I6, 17, I868; New York Sun, Mar. 16, 20, I868. Vanderbilt emerged from his stringent situation without apparent trouble. His calm assurance saved a panic. Drew's direct profit was $\$ 80,000$, incidentally it was a matter of conjecture.

' New York Herald, Mar. 19, I868. 
He was impugned of gross venality in open court.' The tale of Mr. Justice Barnard's interpretation of the character of a Supreme Court judge is too long. Suffice to say that the strange storm of injunctions and counter-injunctions had for an object, first, the appointment of a receiver to handle the proceeds of the Ioo,ooo shares of stock which had been issued in violation of an injunction; second, the pursuit of the processes against the Erie directors for contempt of court. ${ }^{2}$ In connection with the receivership there was nothing to receive, as the money in question was all safely over in New Jersey. However, after the resignation of Mr. Osgood, Vanderbilt's son-in-law, Peter B. Sweeny, of Tweed ring fame, was appointed to the vacancy. He was allowed $\$ \mathrm{I}_{50} 000 \mathrm{oby}$ Justice Barnard as compensation for his loss of opportunity to raid the Erie treasury. The writ of Justice Barnard was arranged in the settlement of the matter between the litigants, to the extent that the cases wherein contempt had been committed received the nominal fine of ten dollars.

At this point in the story of the "Erie Railroad War" the setting was changed from Wall Street and the courts to the legislature. If we are to judge from various newspaper comments, the writings of special investigators and the legislative records, it may be safely said that the New York legislature, at that time, was corrupt. Whether more or less corrupt than at other times, we may not say. Results would justify the statement that from $I_{86}$ to 1870 , the New York legislature was the plaything of the "Rings".

The New York legislature now aroused itself and took cognizance of the "Erie War", which was being waged

1 New York Times, Mar. 24, I868. Accusation by Mr. James Brady et al.

'Mott, The Story of Frie, p. 151; New York Herald, Mar. 24; Apr 9. $20,21,24,1868$. 
without and within its gates. On March 5th, Senator lames F. Pierce, of the second district, introduced in the senate a preamble and resolution which called for the appointment of three senators to investigate the "Grave charges. . . made in the newspapers and before the Supreme Court, in reference to the management of the Erie Railway Company." ' Senator Henry W. Genet, of New York, through doubtless laudable motives, anended the former motion so that it directed the committee to report the result of their investigations within twenty days. ${ }^{2}$ The committee was increased to five on the following day on motion of Senator Abner C. Mattoon, of the twenty-first district, who received an appointment.:

The committee held four meetings in all, one in New York and the others at Albany. The witnesses who testified were Horatio N. Otis," secretary of the Erie; J. C. Bancroft Davis, of the Erie directory: David Groesbeck, Drew's broker; Gen. A. S. Diven, vice-president of the Erie: Henry R. Pierson, of the directory: IVilliam G. Edwards, cashier of Bloodgood \& Co., of Wall Street; James M. Cross, a contractor of Newark, N. I. : and William R.

' New York Times, March 6, I868; New York Sun, March 6, I868.

New York Herald. Mar. 6, 1868.

${ }^{3} \mathrm{Mr}$. Mattoon had his son appointed as a sergeant-at-arms to the same committee. The following item appears in the supply bill for 1868. "For J. H. Mattoon, for services and expenses as clerk and assistant sergeant-at-arms of the Comnittee of the Senate appointed to investigate the affairs of the Erie Railway Company, one hundred dollars." (Lazes of New York, I868, C. 717, p. 1586.) The members of the committee were as follows: James F. Pierce, of the second district; Abner C. Mattoon, of the twenty-first district; Orlo W. Chapman, of the twenty-fourth district: Wolcott I. Humphrey, of the thirtieth district.

"62 Broadway. N. Y., March loth: and at the Delevan House. Albany, March 13.39 and 24.

"Senate Documents. I868. vol. v, no. 67, passim. 
Bradiord, of the firm of Fisk, Belden \& Co. A number of other witnesses were subpoenaed, but were not to be located by the sergeant-at-arms of the senate. Among these were Daniel Drew, John S. Ellridge, president of the Erie; lay Gould, Jim Fisk, and Homer Ramsdell. Incorporated in the testimony were copies of the minutes of the board of directors in relation to the matter at hand: copies of the various contracts with Drew. ${ }^{1}$ the lease of the Buffalo, Bradford and Pittsburgh Railroad, the proceedings which led up to the agreement between the Erie and the Boston, Hartford and Erie Company, to guarantee the bonds of the latter: and the statement made by President Eldridge in justification of the matter that had led to the investigation. The testimony of J. C. Bancroft Davis was the leading evidence adduced by the committee concerning the conduct of Erie finances. The only evidence offered by the Erie directory was a printed statement verified by J. C. Bancroft Davis.

As a result of the committee's labor, two reports were subnitted to the senate on April ist, a majority report, ${ }^{2}$ signed by Senators Pierce, Bradley and Mattoon, which scored the existing Erie management, and a minority report, ${ }^{3}$ signed by Senators Chapman and Humphrey, which sustained the Erie officials. The report, signed April Ist, was turned in favor of the Vanderbilt interests by the deciding vote of Senator Mattoon. This worthy Solon gave an excellent though disgusting example of a legislator for sale. It is difficult to explain away statements of the following character. as sworn to by Daniel Drew before the senate committee of investigation.

O. "Was anything said in the conversation, between him

1 Senate Documents. IR68. vol. v. No. 67. p. 34 et seq.

" bid.. pp. I-7.

Ibid., pp. 8-1.3. 
and you, in regard to the payment of any money, or offer of money, on either side, to procure the passage of a bill in the interest of the Erie Railway Company?"

A. (By Drew) "I think that Mattoon made use of this language to me at one time, that he, or no man, could go there [Albany] and live on what their pay was. I said to him: "I don't know; I have nothing to do with this matter at all, in any way or shape, and will not have.' He intimated as if he would take money if it were offered to him." 1

Senator Mattoon's frequent secret visits to interview members of both factions before the committee made its final report, if not to be so interpreted. certainly were suggestive. $^{2}$ He had given his formal assent on March 3 Ist to a measure proposed by two of the committee which largely exonerated the Drew faction. ${ }^{3}$ The other two

1 Senate Documents, 1869 , vol. v, no. 52, p. I09.

Ibid., pp. 10, 45-52.

3 The majority report, after a summary of the facts brought forth, gave a scathing rebuke to "Mr. Drew and his confederates.-But the want of legal authority is the least objectionable feature of these transactions.--These men occupied positions of trust and confidence; they had entrusted to their care and management immense pecuniary interests, and a property valued at nearly one hundred millions of dollars. By every principle of law, by every dictate of honor and good morals, they were bound to exercise their best skill and judgmentespecially were they under the most sacred obligations to be faithful and honest in the discharge of their duties."-Scnate Documents, 1868, vol. v, no. 67 , pp. $1-7,7-13$.

In sharp contrast with the above, the minority report, which would have been the majority report but for the accident of Senator Mattoon's change of sides at the eleventh hour, declared that the charges against the Erie Directory had not been proved. "Even though the undersigned might not interpret the law as going to the extent claimed by the Erie Directors, they can readily see that, under previous constructions of that law,-especially after legal advice to that effect, the directors might well have believed,-that they had a right to pass such a resolution, and that as a board of directors, they are not chargeable in the passage of that resolution with a wilful violation 
members of the conmittee read to him on the same day their report in favor of the Central. Thus Mattoon held the key to the situation. Whether he was " seen " by both sides is a matter of uncertainty. However, it is of record that on March 30 th, on his visit to the Erie exiles at Jersey City, he told them that "the majority [of the committee] had found the thing was right." " While there is no record of Mattoon's visiting the other side later, the thought does not seem improbable in spite of his sworn denials, ${ }^{2}$ for the day following his visit to Jersey City he signed the measure which favored Vanderbilt. ${ }^{3}$ This sudden change was popularly believed to have been caused by more potent encouragement from the Vanderbilt side. In his testimony before the committee of investigation, Jay Gould evidently spoke the truth when he said, "I was perfectly astounded when I heard he had signed the other" [report]. " The New York Tribune made a bold charge that $\$ 20.000$ had been stipulated for the change. ${ }^{5}$

Parallel with the course of the investigation conmittee, a bill had been introduced into the assembly which legalized the recent issue of new stock on the part of the Erie, regulated the power of issuing convertible bonds, and provided for a standard-gauge connection with Chicago. It also

of the law, if in fact there was a violation, a point upon which your committee think there may well be an honest difference of opinion. And the undersigned believe that had it not been that outside parties were interested in obtaining control of the said Erie Railway Company, no question would ever have been made over the right to pass such a resolution, or issue the convertible bonds in accordance therewith."

1 Senate Documents, I869. vol. v, no. 52, p. 31. "Ibid., pp. 45-52.

"It is said that he could not keep faith, even with his "pals", the gamblers. He told them to throw for Drew.

- Senate Documents, I869, op. cit., p. 33.

see New York Tribune, April 1, 1868 
guaranteed the bonds of the Boston, Hartford and Erie, and forbade the consolidation of the Vanderbilt and Erie systems. ${ }^{1}$ This bill was decisively defeated by a vote of eighty-three to thirty-two ${ }^{2}$ on March 27 th. When the news of this adverse decision reached Jersey City, it was at once decided that their interests demanded the presence of a principal at Abany. Senator Mattoon had suggested that he "thought it was an act of justice to the committee that some representative of the road should come up here [Albany | and explain away these prejudices" 3 [against the Erie bill]. It was decided to send Jay Gould. The Erie people later claimed that an agreement had been made between Mr. Field and Sheriff Janes O'Brien that Gould should be present on April 4 th, the day on which an attachment issued by Justice Barnard on March 3oth against Gould was returnable. ${ }^{4}$ Gould was not to be interfered with by the law before that time.

It was given out that Gould had gone West in the interests of the eighty-seven miles of standard-gauge connection of the Erie with the Michigan Southern and Northern Indiana Railroad Company. Gould arrived at Albany on Monday, March 30 th, and was arrested in his room shortly after one o'clock Tuesday morning. ${ }^{5} \mathrm{He}$ at once telegraphed word of his predicament to his counsel, David Dudley Field. ${ }^{B}$ Sheriff James O'Brien immediately took

${ }^{1}$ New York Herald, Mar. I4, I868. Introduced by Mr. Bristol.

'New York Times, Mar. 28, r868.

S Senate Documents, 1869, op. cit., p. 31 .

' Mott, op. cit., p. 152.

5 New York Sun. April I, 1868.

- Mott, The Story of the Erie, p. 152.

David Dudley Field, New York:

Albany, March 31, I868.

I am just arrested by the Sheriff, returnable Saturday. This is in violation of your agreement with the Sheriff. Bail $\$ 500,000.00$. Jay Fould. -New York Sun. April I, 1868. 
Gould to New York where he was arraigned on ipril $4^{\text {th }}$ before Justice Barnard. Gould's counsel, including exJudge Pierrepont and James T. Brady, mollified the wrath of Justice Barnard and Vanderbilt's counsel. .In adjournment was ordered until April 8th with an additional bail bond required for security. The sheriff was inmediately supplied with a writ of habeas corpus to produce Gould before Judge Barrett of the Court of Common Pleas. There Judge Barrett transferred Gould to the custody of a special officer of his court, one James A. Oliver, who was to hold him until the day set for the adjourned hearing before Justice Barnard. The proceedings in the habeas corpus case were put over until the morning of $A$ pril 7 th. ${ }^{1}$ Gould immediately found that certain interests required his presence at Albany. The officer, who had been specifically instructed by the court never to let Gould out of his sight. was easily persuaded to accompany the latter to Albany. On the train Gould became suddenly sick and kept getting worse until his arrival at Albany, where he called medical attention. $^{2}$ Althongh Gould had been able to attend to his business duties at the capitol, he was much too ill to think of returning to New York, when that was suggested by his guard, in order to appear before Judge Barrett on April Ioth. ${ }^{3}$

On the advice of his counsel, Gould locked hinself in his room, refusing to see Oliver, his guard, who perforce, had

1 Mott, op. cit., p. 154. New York Herald, April 9, 10, 1868.

- The physician called was Dr. Julian T. Williams, a former member of the Assembly from Chautauqua County. Doubtless, one who could be trusted to diagnose and properly prescribe for a virulent case of un mal de la politique.

"Judge Barrett had put the hearing over another three days, on hearing from Oliver by telegraph, that Gould was ill in bed. This was the first intimation that the judge had that Gould was out of his jurisdiction. 
to return emptyhanded to New York. Judge Barrett, in great anger, ordered Mr. Gould and Hamilton Harris, the former's counsel, to appear before him on the I4th. Proceedings on that date found no Jay Gould present, but an affidavit which denied Oliver's declarations and which insisted that the former's state of health did not permit. ${ }^{1}$ The court then postponed action in Gould's case until April I 8 th.

An incident occurred at this time which threatened to disturb the conscience and injure the good name of the legislature. On April Ist, just after the ratification of the railroad committee's report adverse to the bill which legalized the acts of the directors of the Erie Railroad Company, a quiet, white-haired gentleman arose in his seat in the assembly, and to the intense astonishment of all offered the following charges: "that the report of the Erie Railroad bill was bought "; " that a portion of the vote on this flcor, in adopting the said report, was bought"; and "that the members of this house were engaged in buying their fellow members "." This gentleman, who had arisen to a question of privilege, was Assemblyman Elijah M. K. Glenn, of Wayne County. These charges were supplemented with affidavits. In order to quash all further reflections upon the legislature's purity, upon motion of Mr. Glenn, the speaker immediately appointed a committee of five to probe the matter. ${ }^{3}$ The press of the State, which had been hurl-

${ }^{1}$ Gould agreed that he locked Oliver from his room to prevent the latter's learning of the Erie movements which, Gould claimed, it was his practice to narrate to Senators William M. Tweed and Thomas J. Creamer, of the opposing side. Cf. New York Herald, April 15, I868; New York Times, April 15, I868.

- New York Herald, April 2, I868; New York Sun, April 2, I868.

3 Those appointed were: Augustus G. S. Allis, of Onondaga County; James R. Button, of Cattaraugus County; James D. Lasher, of Oswego County; Lewis P. Dayton, of Erie County, and Alexander Frear, of New York County. 
ing charges of gross venality in connection with the Erie measures, now stood solicitiously by to aid in its sad duty. Mr. Glenn obtained a leave of absence for a week. He returned on April 9th, and, still further, startled his colleagues by formally charging that Assemblyman Alexander Frear ${ }^{1}$ had been the person who attempted to influence him, with $\$ 500$, on March 27th, for his vote on the Erie matter. Mr. Glenn demanded that Mr. Frear be relieved from service on the committee. ${ }^{2} \mathrm{Mr}$. Frear at once offered his resignation as one of the committee, with a great show of injured dignity and demanded an investigation. ${ }^{3}$ The matter was placed in the charge of the committee itself to investigate before any action on the resignation should be taken.

The action of the committee was immediate. It met on Thursday morning, April 9 th, to receive the evidence of Mr. Glenn, and again, on the afternoon of the same day. At the second session, Mr. Glenn failed to appear in answer to the subpoena, stating that he was ill, and, that he had given at the morning session all the facts within his knowledge. ${ }^{4}$ The others examined at the second session were Mark M. Lewis, of Albany, who by vocation was an optician, by avocation, a lobbyist; Alexander Frear, assemblyman from New York City; Henry Ray, assemblyman from Ontario County; Luke Ranney, assemblyman from Onondaga County, and Augustus A. Brush, assemblyman from Dutchess County.

The testimony of Mr. Glenn proved to be ineffective and weak in places. He swore that on the morning of March 27th, while conversing with Hon. Charles H. Weed, of

1 A New York City broker. New York Herald. April Io, I868.

- Assembly Documents, i868, vol. x, no. I45, p. I.

- $C f$., Papers.

4 Assembly Documents, I868, vol. x, no. I45, p. I7. Testimony of Mr. Gleason who explained Glenn's absence to Mr. Allis, the chairman. 
Cayuga, and Hon. Henry kay, of Untario, they had volunteered the statement that "there was money afloat". Glem replied, "Is it possible, how did you find out?" "Why," said one of them. " it is easy ellough to find out. (io in the cloakroon, you can find out. l've seen you talking to the man." "I went out and iell into conversation with hin [tewis] about spectacles, and about his business, and led him on." It appeared that .Mr. Lewis sairl nothing to Glemn in regard to money. Therempon Mr. Glenn returned to the assembly chamber and reported the result to Mr. Ray, who shortly notified the former that lewis was ready to talk with him. Mr. Glem then said:

l went out again, and just as I swung thic door square open and passed into the cloak room, Lewis took hold of my coat and hauled me to one side and said. 'I want to talk to you.' We got up close to the wall, and says he. 'I don't want you to be offended.' 'Oh, no,' said I. . . . He said the railroad report was to be against the Erie road, and, said he, . . . 'If you vote for it you shall have $\$ 500$. . . . If you will go back to your seat. Brush will come to see you."

Mr. Glenn returned to his seat. but after a considerable wait he returned to the lobby and informed Mr. Lewis that $\mathrm{Mr}$. Brush had not come to him. Lewis told him to go to Mr. Frear, to which Mr. Glenn retorted, "I ain't going to any man." Thereupon, Lewis sent in for Mr. Frear, who came out presently and said to Mr. Glenn, "What this man says," nodding his head to Lewis, " is all right; we want the

1 Assembly Documents, 1868, op. cit., p. 5.

"Mr. Glenn stated in relation to Mr. Brush that "the moment I tried to catch his eye. I saw there was guilt there. All winter long he had a clear, frank, open face, but the moment I would catch his eye he would dodge off from me." Assembly Documents, 1868, vol. $x$, no. 145, p. 6 . 
Erie Railroad report adopted, and if you will vote for it, you shall have what this man says." ${ }^{1}$ It appears that Mr. Frear's nane was introduced in the matter for the first time at this juncture. The evidence further shows that $\mathrm{Mr}$. Frear's presence in the lobby was requested several times before he left his seat."

It is at this point that the testimony of Mr. Glenn appears to contradict the sworn statements of Mr. Frear and Mr. Lewis. The former positively swore that Glenn asked him if he would obtain five hundred dollars in return for a vote sustaining the report of the committee. Mr. Frear, according to his statement, replied: "I told him no; that I was very anxious to have the report of the committee sustained, and as far as I was concerned I did not think that this legislature could afford to pass a bill of that kind, referring to the Erie bill ". ${ }^{3}$ Mr. Glenn then began to state that he had had a talk with Mr. Lewis, whereupon Mr. Frear said that he left Glenn, saying. "Then go and talk with Mr. Lewis." 4

Mark M. Lewis, in his testimony, stated that he did not offer money to $\mathrm{Mr}$. Glenn, that he had received no authority from any person or source, directly or indirectly, to offer to pay money to any person for his vote on the Erie bill." He claimed to have merely stated rumors which had come to his ears, namely, that the Erie side were offering five hundred dollars down and a like amount contingent; also, that the other side were offering five hundred dollars. In reply, Mr. Glenn was charged by Lewis with these words. "If there is anything in it, I want to get my share."

'Assembly Documents, op. cit., p. 6.

"Ibid., p. I3

"Ibid., op cit., p. 6 el seq.

'Ibid., p. I4.

${ }^{5}$ lbid., p. 8 it seq. 
In their evidence, both Mr. Frear and Mr. Lewis swore that they were not personally acquainted with each other, and that they had never held a conversation upon the Erie bill or any other matter. ${ }^{1}$ When asked how he had happened to give Mr. Frear's name to Mr. Cilenn, Lewis replied that he had given the names as they occurred to inim. However, following that remark. Lewis admitted a weightjer reason. It seems that $\mathrm{Mr}$. Lewis was interested in securing favorable action upon the health bill of the town of Watervliet. In order to advance the interests of his own measure, Lewis sought to do Frear a favor. The former heing aware that the latter was against the Erie measure, it occurred to him that Frear would consider it a favor for a nember to vote against it. Mr. Lewis had inferred that Vrear was against the Watervliet health bill, hence, he was desirous of placing himself in a position where he could possibly ask a return favor of Mr. Frear. ${ }^{2}$

The evidence offered by Assemblymen Ray and Ranney tended to show that the sending of Mr. Glenn to the cloak rom was a joke. which resulted from a jest at the breakfast table. Mr. Henry Ray and Mr. Luke Ranney boarded at the same house with Mr. Glenn. It appeared that at the breakfast table on the day on which Mr. Glenn claimed that the attempt at bribery was made. the three gentlemen above mentioned had laughed and joked over the buying of votes. Mr. Ray testified that Glenn had said that " he didn't know but what he would like to take a look at the elephant", whereupon Ray replied, "If you want to find out what there is of it, you can go and talk with the Dutchman" Mr. I ewis]. Mr. Ray testified that "nothing serious was ineneited in thic converation." In reply to a direct ques-

1 Assembly Documents, vol. x, no. 145, p. 8 et seq.

' hid., p. I2.

Irid.. p. 15. 
tion whether he had received any money for his vote on the Erie bill, Mr. Ray gave an illuminating reply as to the legislature's sensitiveness on the question of bribery.

No, sir; after the session of the House, on the 27 th, myself, Mr. Glenn and others, both in the chamber and at the house, were laughing about this matter; and $\mathrm{Mr}$. Glenn said [as we understood in a joke] that he had lost $\$ 500$ that day which he might have got . . . more than he had ever lost before in one day; we often joke about money being lost in that way.'

The evidence of Mr. Ranney was in point with that of Mr. Ray. ${ }^{2}$ Mr. Augustus Brush, whose name became involved in Glenn's testimony, denied having any knowledge of money being paid to anyone to influence the vote on the Erie matter. ${ }^{3}$

In face of the evidence taken there is little doubt that the commitee were justified in their recommendation "that Mr. Frear's request to be excused from serving on the investigating committee be denied," and that the charges made by Mr. Glenn against Mr. Frear were unjustified. Did they not have the testimony of five men, whose word had never been impeached, against that of one, whose testimony was presented in an unconvincing form? Nevertheless, it is difficult to reconcile the presence of Jay Gould accompanied by his host of lobbyists at Albany, and his sworn statements of the amount of money he spent at . 11 bany for various purposes to advance his bill, with an uncorrupted legislature. Mr. Glenn may or may not have purposely been made a tool to clear the legislature of stain; Mr. Frear may have been spotless; yet the fact remains that the Erie and Vanderbilt interests were at Albany, supplied with large sums of money, both in deadly grapple over the

1 Assembly Documents. I868, op. cit., p. 15.

Ibid. pp. 15-56.

Ibid.. pp. 16-I7. 
Erie measure; in the senate was William M. Tweed, who, as it has since been proven, was extending his corrupt power in the legislature and over all the State. In view of these facts, the question cannot fail to arise whether or not the legislature was corrupted in this particular case. ${ }^{1}$ The only authoritative knowledge left us on which to base an opinion is the testimony of the committee to investigate Mr. Glenn's charges. This committee completely exonerated the legislature. IVe leave the question.

Now that the legislature had been purged, few would dare to repeat Mr. Glemn's attempt, hence the season was ripe for Gould's bounteous generosity. The reports which circulated concerning the size of bribes which were dealt in through this legislative campaign were multifarious. The amounts involved were stated to range from $\$ 5,000$ to $\$$ IOO,OOO. ${ }^{2}$

Although the situation since Gould's arrival at Mlbany appeared to favor the Erie, still the defeat of the assembly bill, and the fact that the senate committee had reported adversely, argued for the supremacy of Vanderbilt. A factor which no doubt tended to strengthen the Erie forces at this time was the awaking of public opinion to the danger of a consolidation of two great systems under the direction of Vanderbilt. Be that as it may, the Vanderbilt influence waned. A bill" which legalized the acts of the Erie

1 Townsend, New York in Bondage (New York, I901), pp. 8-17. Mr. Townsend in his chapter on the Erie War makes a special study of the relations between the Erie Railroad and the Tweed Ring.

'New York Times, April 2, I4, I868; New York Tribune, April 1, 1868; New York Herald, Mar. I0, I4, I868; May I, 1868.

${ }^{3}$ Cf., New York Sun, April 14, I868. Adams, A Chapter of Erie, p. 54. To all intents and purposes it legalized the recent issue of bonds but penalized any other use of the proceeds of these bonds, than for the completion, furthering and operation of the road. The 
directory was introduced in the senate on April I $3^{\text {th }}$ and passed after a close debate on the I8th. ${ }^{1}$ Senator Mattoon, for unknown reasons, was found voting with the majority. The scene of battle now turned to the assembly. At first, the scent of the death struggle caused a great influx of political vultures, but they were doomed to go unsatisfied. Shortly the rumor gained credence that Vanderbilt had withdrawn. This proved true. The bill was passed by the assembly on April 2oth by a vote of one hundred and one to six. ${ }^{2}$ To punish Vanderbilt for failing to continue the fight, thus stopping a source of profit, the disappointed members of the assembly passed several measures calculated to injure him. Among these were a pro rata freight bill, $^{3}$ and a through ticket bill, where there were competing lines. ${ }^{4}$

The last stand was made in the executive chamber at Albany before the bill received the Governor's signature. There, on April 2ist, the Vanderbilt counsel made their closing argument as to why the bill should be vetoed. However, it availed them nought. Governor Fenton rewarded the Erie labors with his signature. The papers ${ }^{5}$ were rife with charges that the Governor's signature had been bought.

guarantee of bonds issued by connecting roads was legalized, all consolidation or connection and the use of the same officers or directors, between the Erie and the Vanderbilt lines was forbidden.

' I7 to I2. New York Sun, April I4, I868; New York Herald, April I9, 1868 .

${ }^{2}$ Mott, The Story of Erie, p. 154. The same bill had been defeated before 83 to 32 .

3 New York Herald, April 19, 20, 1868.

- New York Herald, April 21, 29, i868. Also, an enahling act was passed April 2I, I868, for the West Side R. R. between New York and Albany to rival the Central.

5 See papers. New York Herald, April 21-30, I868: New York Times, April 20-May 8, 1868; New York Sun, April 21, 1868. 
Although papers of his own party named the sum supposedly paid. the evidence adduced by Senator Hale's inrestigation committee does not bear this out.'

While the angry clash of counsel in the courts lasted nearly to June, the defeat of the Vanderbilt faction in the legislature brought on an era of negotiation. The press all through the spring months provided the curious public with new notes on the science of high finance. So satiated did the public become that it grew indifferent to new disclosures of scandal. ${ }^{2}$ Early in . Ipril. I)rew atforded hinself the opportunity offered by Sabbath immmity from arrest, to cross the Hudson. Shortly peace conferences were arranged between Vanderbilt and Drew. The latter had become irritated and oppressed by the long drawn-out publicity of the Erie war. He had no sanctity of personal or private business, was distrusted by his associates, and was fain to return to the comforts of his home. Vanderbilt, on the other hand, appreciated the fact that public sentiment against him was too strong to be downed. Hence, the settlement which ended the Erie war may not appear so strange.

O11 . Ipril 25th, the Erie forces evacuated their stronghold in Jersey City. This was not done until a satisfactory peace had been arranged. subsequent to the frequent stealthy, then open, visits of Mr. Drew to Wall Street. The inside facts of the settlement have never come to light. When the Ulbany matters had received final settlement, the plan of compromise, which was the result of the secret conferences between Vanderbilt and Drew, had been outlined. The four parties to the settlement and their desires, in the case of three, were plain. Mr. Drew was anxious to square

1. See Doc. Sen., 1869, no. 52. pp. 146-148, 151-55.

'Adams, op. cit., p. 56; New York Herald, April 26, 1868. 
his account as treasurer. while Vanderbilt wished to unload his great burden of Erie stock and to protect his puppets, Messrs. Work and Schell, under whose names the litigation had been carried on. The Boston interests were especially desirous to be lightened of the New York and Erie Railway, so as to be able the sooner to devote their hardwon spoils to the development of the New England enterprise. " One party only was unprovided for, "those splendid pirates, Jay frould and 'Jim ' Fisk." "

Gould's reasons for not desiring to compromise with Vanderbilt, while unknown, were none the less strong. Gould's other self, lisk, coineided with Gould. As a result an attempt was made to effect a compromise withcut their knowledge. $\therefore$ secret meeting, arranged to be held at ex-Judge Pierrepont's on an early June evening." between the Erie board of directors and counsel and Vanderbitt and counsel, was broken in upon by Gould and Fisk. After fruitless protests on the part of the intruders, they were forced to acquiesce in a settlement from which they obtained nothing but fuel to kindle further trouble. Mr. Fisk, in his sworn testimony, declared that Gould and he protested to the last. denouncing the compromise in the most scathing terms. His prediction that it would produce future trouble. was well borne out by subsequent events.

All the charges against the Erie were dismissed on the motion of the Central's attorney. Charles $A$.

1 Adams. op. cit., p. 58 .

3 Tarbell. The History of the standard Oil Company (New York, 1904), pp. [-33.

3 Mott, op cit. p. 155. The exact date is unknown. It the time of the meeting. President Eldridge had an appointment with Gould and Fisk at the Fifth Avenue llotel. When he failed to appear, they inmediately gave credence to rumors of a secrel meeting and went direct to Pierrepont's house. 
Rapallo. The formal announcement of the final settlement was made on July 2nd. The settlement included a cash subsidy outright of $\$ I, 000,000$ to Commodore Vanderbilt, in return for which the Erie was to have the privilege of purchasing from Vanderbilt fifty thousand shares of Erie at seventy on demand within four months. Vanderbilt was also to be lightened immediately of fifty thousand shares of Erie stock at seventy, the stipulation being $\$ 2,500,000$ in cash and guaranteed Boston, Hartford and Erie bonds at eighty to the amount of \$I,250.000. Further, Vanderbilt was permitted to hold two seats in the Erie board. Also, it was agreed that all pending suits be dismissed. To heal the offended feelings of Messrs. Work and Schell and to recoup them for their losses, they severally received $\$ 429,250$ in cash. To Daniel Drew all the fruits of his exploitation were given, with the exception that it was provided that he should pay into the Erie treasury $\$ 540,000$ with interest, to balance his account with the Erie Company. The Boston interests, under the leadership of President Eldridge, fared well. The agreement called for the purchase of $\$ 5,000,000$ Boston, Hartford and Erie bonds for $\$ 4,000,000$ of Erie acceptances. In all, the Erie treasury, which had been temporarily well filled, was depleted to the extent of $\$ 9,000,000$ in cash to settle this matter of the disposition of trust property. To requite the outraged feelings of Jay Gould and Jim Fisk, the settlement provided that they should have the Erie Railroad. In its existent condition, there is small wonder that they were dissatisfied with their share. Yet, it was destined to be the royal highway to many fortmes in their skillful, though unscrupulous hands. ${ }^{1}$

The curtain dropped on the Erie litigation of I868, when

${ }^{1}$ See An Erie Raid, in Adams, Chapters of Erie, also pt. iii in A Chapter of Erie, Adams, Chapters of Erie. 
on June zoth, Directors Davis, Lane, Skidmore, Diven, Thompson and Eldridge were fined ten dollars by the muchabused Mr. Justice Barnard, for technical contempt. ${ }^{1}$ The great malefactors, Messrs. Drew, Gould, and Fisk received no punishment; eviclently Justice Barnard considered their crimes too grave for treatment. ${ }^{2}$ Mr. Vanderbilt apparently turned his glance from the Erie, though it must have been with a wistful look. For the time being Daniel Drew made himself a center of attraction in Wall Street by assuming the rôle of looker-on.

The scope of this study does not permit a further development of the Erie story. Suffice to state, that Messrs. Gould and Fisk, freed from the timid vacillation of Drew, soon made the Erie fill their coffers a hundred fold. Their methods were similar to those of their master: the unscrupulous use of trust funds, shady Wall Street corners, a suitable manipulation of the legislature, a vast tangle of injunctions and suits in the various city and country courts. The names of Peter B. Sweeny and William M. Tweed, "remorseless, vulgar, public robbers"," shortly appeared upon the Erie board of directors, thus assuring the Erie ring of the support of the Tweed ring. An even exchange of legislative votes for money is no robbery: hence the respective parties were satisfied. Gould was permitted, through the favor of Tweed, to have the Erie directors' bill passed, which enabled him to keep his hold upon the Erie board for five years, by the yearly retiring of only one-

${ }^{1}$ Mott, The Story of Erie, p. I56; New York Times, July I, I868; New York Sun, July 1, 1868.

2 On April 21, I868, Gould was exonerated by Justice Barnard of any intention to commit contempt of court. New York Times, May 8, I868; New York Herald, May 21, 1868.

' Livingston, The Erie Railway: Its History and Management, p. Io. New York and Erie Railroad-Pamphlets. 
fifth of the board. There is little doubt that IV all Street has seen, since the time of Drew and Ciould, nany transactions of high finance which would blush with the light of day, yet, it would be hard to picture a more bare-faced case of financial or legislative debauchery. That such a condition could exist, with the perpetrators walking erect in public, even envied in many quarters, speaks for itself as to the state of public conscience of that period. However, there was shortly an awakening. Within the past decade, althutgh the muckraker has ceased to be popular, the plane of public opinion and conscience is so much higher than that of five decades previous. We believe that the methods of Gould would find no harborage to-day.

The aim in outlining this deplorable yet nevertheless interesting period of legislative, judicial and financial degeneracy has been to suggest the peculiar conditions in New York State which placed the Democrats in control of the State administration in I868. That there can be no doulbt of the corruption rampant in the legislature of 1868 is made manifest by the report of Senator Hale's committee. which while it found no proof of the actual bribery of any sentator. yet found that large sums of money hid been expended for corrupt purposes by parties interested in the railroad legislation of 1868 . This committee. composeci of Senators M. Hale, Francis S. Thayer, and Isher P. Nichols, was appointed on April ro, r868, and sat at various times during the following recess and the next regular session. Its report was submitted eleven :110nths later. March I0, 1869 .

Horace Greeley was summonted before the committee to state his grounds for the statenent that over \$100,000 had been expended by buth sides on the Erie matter. Ciree-

${ }^{1}$ Senate Documents, i869, vol. v, no. 52, p. I et seq. 
ley named the Hon. Thomas C. Fields as his informant. Among the others examined by the committee were: Jay Gould, Cornelius Vanderbilt. Jr., Thomas G. Alvord, Abner C. Mattoon, Asahel H. Cole, Lewis F. Payne, Daniel Drew, John H. Mattoon. George Bliss, Jr., Alexander S. Diven, Luther Caldwell. James Fisk, Jr., and Hamilton Harris.

Mr. Drew testified that while treasurer of the Erie, until July. I868, Mr. Eldridge, the president of the road, drew $\$ 500$,ooo irom the treasury before the session of the legislature, ostensibly for purposes of litigation. ${ }^{1}$ This was charged to Mr. Eldridge personally and had not been accounted for when Drew had retired from office. The committee found that large amounts of money had been paid for varions purposes. Jay Gould had paid \$5.000 to Lewis l. Payne and $\$ 2,000$ to some person, " he thinks his name was William King ". ${ }^{2}$ to be given to Mr. D. D. S. Brown, of Rochester. In addition. Gould testified that he paid somewhere from $\$ 25.000$ tir \$\$0,000, not inclurling payment by draft, to commsel and agents. Mr. Thompson paid $\$ 5.000$ to Payne and close to $\$ 60,000$ to Luther Caldwell. which hal been refunded to him by the Erie Company." The committee felt sure that it knew where all this money came from, but Mr. Eldridge. being a resiclent of another State and having failed to accept its invitation to testify, the committee could not force him. The committee, while not knowing exactly the use made of this money. assumed that it had been expended for some purpose with intent to influence legislation mlaw fully. ${ }^{4}$

Some typical instances of the manner in which the funds

1 Senate Documents, op. cit., p. 3.

Ibid., p. Iro.

¿lbid. Pl1. 1 q0-1.

' hid.. p. 3. 
were disposed of will be interesting. For example, Lewis F. Payne, a harbor master in New York on a \$350 per month salary, a man who had never been employed by any railroad, with neither profession nor any extensive influence, was given $\$ 5,000$ by $\mathrm{Mr}$. Thompson ${ }^{1}$ and later $\$ 5$, ooo by Mr. Gould " to smooth him over", Gould not having heard of Thompson's payment. In return for this $\$ 10,000$ it appears that Mr. Payne spent a few days at Albany advocating the Erie bill.

The case of Luther Caldwell is still more peculiar. From the testimony of Horace Greeley, Mr. A. N. Cole and Senator Russell F. Hicks, it appears that

the party known as the Vanderbilt party, or the opposition to the bill, had made a proposition to him [Caldwell] to have him leave Albany, and that he [Caldwell] had informed Mr. Gould of the proposition they had made him, and that he told Mr. Gould he was going away; and they [the Vanderbilt party] proposed to give lim $\$ 70,000$ if he would leave; that they did so, and he went away; that he had before received from the Erie side a very liberal compensation for his services... which was paid him in all kinds of bills. ${ }^{2}$

General Diven, of the Erie, stated on examination that Henry Thompson, a director of the company, had told him that Caldwell had received something like $\$$ roo,ooo from the Erie the day or so before the vote was taken. Caldwell had then left the city. Exactly who had paid Caldwell this money does not appear from the testimony.

Several unsuccessful attempts were made to bring $\mathrm{Mr}$. Caldwell before the committee to testify. At length their efforts were successful. When asked by the committee the leading questions as to whether he knew of moneys being

1 Senate Documents, op. cit., p. I4I et seq. Payne later became a prominent figure in the State politically.

albid., p. II 9 . 
paid by interested parties for or against the bill, or to anyone for the purpose of securing the vote of any senator, and whether he had received any money from any one interested in opposing the bill, Mr. Caldwell asked for opportunity to reflect whether he would answer the question. ${ }^{1}$ He was given until the next morning, at which time he did not appear. That was the last the committee saw of him. It was learned later that he was sojourning in the Southern States.

Mr. Henry Thompson swore that he had given Caldwell, at one time, $\$ 10,000$ and at another $\$ 50,000$, which was for no other purpose unless to influence public opinion. ${ }^{2}$ From Senator Hicks' testimony it appears that the money Caldwell received from the Erie was for "services", and from the Vanderbilt party for "leaving Albany"." That such large sunns of money were paid for the services of Caldwell or for his short absence from Albany seems incredible.

The charges in connection with Senator Mattoon were gone into at length without anything definite being discovered. ${ }^{*}$ Senator Graham, also, it appears from Daniel Drew's testimony, had an itching palm, but Mr. Drew merely "drew an inference" that the senator wanted money or the promise of it."

In bringing its report to a close the committee made a savage attack on the papers for "the utter recklessness" " with which they hurled charges at the legislature without proper basis in evidence. The Tribune, the New York Independent, the Rochester Democrat, the Brooklyn Union, and the New York Citizen were especially mentioned.

\footnotetext{
1 Senate Documents, op. cit., pp. 129-131.

2 Ibid., pp. I40-I.

${ }^{3}$ Ibid., pp. I18-22.

'Ibid., pp. \$5-52, 122-124

stbid., pp. I0, II4.

'Ibid.. pp. I I.
} 
'The results of the committee's prolonged task were summed-up as follows:

1. Large sums of money were expended for corrupt purposes by parties interested in legislation concerning railways rluring the session of 1868 .

2. Lobbyists were thus enriched; and in some cases received money on false pretense that the votes of Senators were to be thereby influenced.

3. There is no proof of actual bribery of any Senator.

4. The newspaper charges made in the instances that were bronght to the notice of your Committee were founded on rumor alone, and have been in no case sustained by the evidence of the writers or other proof. '

After this comfortable senatorial whitewashing, the committee went on to recommend a law which would exempt the giver of the bribe from punishment. As the conmittee pointed out, certainly with some justification, it was almost impossible to convict under the present laws. "The result is either a refusal to testify. or remarkable forgetfulness or something worse." 2

The committee closed its report with the further recommendation that legislation be passed to prevent the depcisit of large sums of money with members of the lobby and to prevent the use of corporation money by officers or directors with intent to violate the laws against bribery. ${ }^{3}$ Although the action of the senate in ridding itself from taint was far more dignified and thorough than that of the assembly, the result proved the same. Perhaps the committee were sincere, who knows?

'Senate Documents, op. cit., pp. 140-I.

"Ibid., p. 12. "Ibid.. p. I3. 


\section{CHAPTER Xl}

The National Nominating Conventions of i 868

THE REPUBLICAN STATE NOMINATING CONVENTION

Aside from such matters of local interest as the excise. political personalities. the Tweed ring, the canal frauds and the Erie scandal. one finds in considering the political history of New York in I868 that the conventions and the party politics of the State are but echoes of the broader national movements. Moreover, the New York delegations played a leading rôle in the deliberations of both the Republican and Democratic National Conventions, while the State Conventions were mere ratifying bodies. Likewise, the action taken in both the Republican and the Democratic State Nominating Conventions proved to correspond with the part played by each State delegation in the National Nominating Conventions.

The Republican State Nominating Convention met at Shakespeare Hall, Syracuse, on February 5, r868, to select delegates to the National Republican Convention at Chicago. The convention demonstrated two points, namely, that there was a strong anti-Fenton feeling and that the Fenton forces were well organized. Hamilton Harris, chairman of the State central committee called the meeting to order, after which Joshua M. Van Cott, of Kings, was made temporary chairman. Each county was filly represented. $38+$ delegates being present. ${ }^{1}$

$$
\text { ' New York Times, Feb. 6, I868. }
$$


On the roll call of delegates the usual contest between the radical and conservative Republicans from New York City developed and was settled in the usual way. Notwithstanding, the annual airing of the Republican situation in New York City proved of greater moment on this occasion than ordinary as it was made a cloak to cover the antiFenton faction in the convention and to organize opposition to Fenton himself. ${ }^{1}$

Mr. Rufus W. Andrews handed up a list of contestants from New York City approved by the signatures of $\mathrm{E}$. Delafield Smith, Thomas J. Murphy, and A. G. Plumb. Mr. E. Delafield Smith addressed the convention insisting that his delegation did not attend the convention to make trouble but to effect a reorganization of the Republican party in New York City. Mr. Smith closed his address by offering a resolution to the effect that the committee on credentials be instructed to report a resolution providing for a reorganization of the Republican party in New York City and County, under the joint supervision and direction of Messrs. Freeman J. Fithian and Thomas J. Murphy."

Charles S. Spencer, the leader of the Radical or regulai (so-called) Republican organization in New York City, made his usual "blood and thunder high-pressure reply", in which he quoted the resolutions, adopted by the Murphy" organization prior to the last State election, approving Johnson's policy and pledging support to John T. Hoffman and Robert H. Pruyn, for Governor and lieutenant-

${ }^{1}$ New York Times, Feb. 6, I868; New York Tribune, Feb. 6. I868; New York Herald, Feb. 6, i868. Official Proceedings of the National Convention of the Republican Party, 1868 (Chicago, I868), (Columbia University Library, no. 308, H 62), no. 16. of a volume of pamphlets.

New York Times, Feb. 6, I868.

3 New York World, Feb. 6, I868.

- Conservative Republicans 
governor, respectively. Spencer also quoted remarks of Rufus W. Andrews, made two weeks prior to the present convention, in which Andrews charged Governor Fenton with being at the bottom of the election of the State committees. ${ }^{1}$ Andrews at that time threatened another convention in April to choose contesting delegates for Chicago. Spencer urged the convention to keep its skirts clear from the Murphy organization, stating that their votes were not needed and would taint the regular Republican organization.

Thomas B. Van Buren and Rufus W. Andrews, representing the Conservative Republicans replied to Spencer at length. $^{2}$ Mr. Van Buren believed that a Republican union in New York City would enable the Republicans to carry the State by 50,000 votes in the fall. Van Buren charged that the Spencer organization had sold out the Republican candidate for mayor ${ }^{3}$ in the last election and had spent time and money to elect Fernando Wood. Mr. Andrews asked why, if the Radical Republican organization was competent to run the party in New York City, there had been a drop from the usual 40,000 Republican votes to I 8,000 in the last election. The Radical organization made no attempt to answer. ${ }^{4}$ After this thorough display, the Fenton forces organized to stop a further exhibition of the party's dirty linen. Mr. A. N. Cole moved that the delegates representing the Radical Republican organization of New York City, headed by Mr. Nathan Kingsley, be recognized and admitted to seats in the convention. Secondly, Mr. Cole moved that the delegates representing the Con-

${ }^{1}$ New York Tribune, Feb. 6, 1868.

${ }^{2}$ New York Hera!d, Feb. 6, 1868.

3 Marshall O. Roberts.

${ }^{4}$ New York Herald, Feb. 6, i868. Freeman J. Fithian made reply for the Radicals. He believed reorganization inexpedient as it might alienate the 25,000 consistent Republican voters in New York City. 
servative Republican organization be invited to seats on the floor of the convention. Mr. Cole's motion was carried by a majority of 235 to $56 .^{1}$ The Conservative delegation from New York City left the hall in a body as a protest.

The contest between the New York City delegations proved to be the most important feature of the convention, and with the contest settled the Fenton forces were able to complete their organization and put through their slate as planned. After a short intermission the convention reconvened at 4:30 P. M., whereupon Charles H. Van Wyck was made president of the permanent organization. $\mathrm{He}$ devoted his address to a review and censure of Johnson's policy. Stanton was lauded as one of the purest of American patriots. Lieutenant-Governor IVoodford and Lyman Tremaine, also, made extended speeches. ${ }^{2}$

Judging from the failure of one-third of the delegates to applaud the Radical Republican speeches, and from the votes on various of the motions, it would appear that approximately one-third of the delegates were opposed to Fenton and his candidacy for the vice-presidency. The strength of the opposition to Fenton was suspected before the convention convened. This decided the Fenton men to take the matter out of the hands of the convention and give it to a committee, ${ }^{3}$ which they were able to do through their superior organization.

The delegates at large, chosen by the convention, were Major-General Daniel E. Sickles, of New York; Lyman Tremaine, of Albany; Charles Andrews, of Onondaga; and D. D. S. Brown, of Monroe. General Sickles was placed at the head of the delegation because it was thought that his friendship for Grant would secure Grant's influence for Fenton. Among the more prominent of the dele-

${ }^{1}$ New York Times, Feb. 6, I868.

${ }^{2}$ Ibid.

3 Ibid., New York World, Feb. 6, 1868. 
gates' names ${ }^{1}$ representing the districts one finds the fol-

1 Congressional District Delegates:

Ist District, Alfred Wagstaff, Suffolk; L. Bradford Prince, Queens. 2nd District, Charles W. Broderick, Kings; Archibald M. Bliss, Kings.

3rd District, Joshua M. Van Cott, Kings; Joseph Reeves, Kings.

$4^{\text {th }}$ District, Joshua G. Abbey, New York.

5th District, Moses H. Grinnell, New York; E. D. Culver, New York. 6th District, Charles S. Spencer, New York; John D. Lawson, New York.

7th District, John Cochrane, New York; W. F. Ashman, New York Sth District, W. R. Stewart, New York; John D. Ottwell, New York. gth District, James W. Culver, New York; Charles H. Cooper, New York.

Ioth District, H. D. Robertson, New York; C. N. Depew, Westchester.

II th District, George Clark, Orange; H. R. Low, Sullivan.

I2th District, B. Platt Carpenter, Dutchess; Jacob W. Hogsdrats, Columbia.

13th District, George H. Sharp, Ulster; Rufus H. King, Green.

14th District, Hamilton Harris, Albany; Borden H. Mills, Albany.

I5th District, Robert M. Hasbrouck, Rensselaer; Alexander Barkley,

Washington.

r6th District, William Rockwell, Warren; Eli W. Rodgers, Essex.

I7th District, Calvin Hulburd, Sr., St. Lawrence; William Gillis,

Franklin.

I th District, Truman G. Younglove, Saratoga; Seymour Sexton, Fulton.

19. h District, Ebenezer Blackley, Otsego; Lewis Kingsley, Chenango. 2oth District, William Dewey, Jefferson; E. B. Livingstone, Lewis. 2Ist District, Ellis H. Roberts, Oneida; George B. Anderson, Oneida. 22nd District, Benjamin B. Bowen, Oswego; Delos W. Cameron, Madison.

23rd District, Frank Hiscock, Onondaga; R. Holland Duell, Cortland. 24th District, John S. Fowler, Cayuga; A. D. Baker, Seneca.

25th District, Peter S. Bonesdale, Ontario; Isaac L. Endres, Livingston.

26th District, Jeremiah W. Dwight, Tompkins; Thomas J. Chatfield, Tioga.

27th District, Stephen T. Hoyt, Steuben; Luther Caldwell, Chemung. 28 th District, E. L. Pitts, Orleans; O. C. Wildee, Monroe.

29th District, John Fisher, Genesee; Andrew W. Brazee, New York. 3oth District, T. K. Bass, Erie; Fred H. Jones, Erie.

3Ist District, George B. Barker, Chautauqua; Patrick H. Jones, Cattaraugus. 
lowing: Joshua M. Van Cott, of Kings; Charles S. Spencer, of New York; Chauncey M. Depew, of Westchester; Hamilton Harris, of Albany; Calvin Hulburil, Sr., of St. Lawrence; Ellis H. Roberts, of Oneida ; Frank Hiscock, of Onondaga; and Luther Caldwell, of Chemung.

Lyman Tremaine reported the resolutions, which were in full accord with the Radicals in Congress. ${ }^{1}$ Reuben E. Fenton was named as the first choice of the Republicans of New York State for the vice-presidency. His great prudence and firmness, his patriotic service while in Congress, and his sagacity as a Governor was affirmed. Republicans were exhorted not to permit the Democrats to overturn the results of Appomattox Court House.

Horace Greeley closed the convention with one of his ironical addresses in which he reminded the Republicans that the strongest vote ever cast against the Republicans was polled the previous fall. He warned them against overconfidence and remarked that something besides talk would be necessary to elect the Republican ticket. $^{2}$

The Radical organization under Fenton's leadership could feel proud of their work as the convention adjourned. It was planned and carried out accordingly to make the convention a Fenton organization meeting. Benjamin Field, Luther Caldwell, temporary chairman Joshua Van Cott, and president of the convention, Charles $H$. Van Wyck, were credited with being the men who forced through the Fenton program. The disturbance caused by the recriminations of the contesting delegates from New York City was the chief difficulty encountered. Although overcome in the convention, the anti-Fenton sentiment reappeared at Chicago, being the cause in some degree for his failure to win the nomination for vice-president.

${ }^{1}$ New York Times, Feb. 6, I868; New York Herald, Feb. 6, I868.

'New York Tribune, Feb. 6, I868. 


\section{THE REPUBLICAN NATIONAL NOMINATING CONVENTION}

The auspices under which the National Republican Convention met in the Crosby Opera House, Chicago, on May 20 , I868, were not all that could be desired. ${ }^{1}$ The friction between an impolitic, unyielding President and a rash, revengeful Congress had changed the current of public sentiment and had created new issues, many previously unthought of, causing wounds still unhealed. These riew issues were largely foreign to those which caused the Civil War. First, questions arose concerning the readmittance of the seceded States and their social and economic conditions, which resulted in the supremacy of the Congressional over the Presidential theory. Secondly, came the issue between the President and Congress over their relative powers. Thirdly, the shorter but equally bitter conflict between the Supreme Court and Congress arose over the powers and functions of each, followed by the withdrawal of the former from the field. Lastly, the attempt to oust the President, with its failure ${ }^{2}$ and resultant loss of prestige for the Congressional party, made a situation the entire course of which enveloped the Radical section of the Republican party in a cloud of suspicion.

The agreement of the delegates ${ }^{3}$ at Chicago on the name of Grant, nevertheless, tended to allay alarm. Grant's name appears to have been accepted without serious question. This naturally lessened the excitement of the convention. Still, considerable interest was awakened over the selection of the vice-president and the formation of a piat-

1 Utica Morning Herald, Utica, May 21, I868.

2 The eleventh article of impeachment failed by a vote of "guilty", 35; " not guilty," 19 (test vote); on May 16, 1868. Ten days later the court of impeachment adjourned sine dic after reaching the same result on the second and third articles.

${ }^{3}$ For list of State delegations $c f$. . New York Tribune, May 19, I868. 
form. The great topic of discussion among the thousands at the convention was the vice-presidency. ${ }^{1}$

The New York delegation centered the attention of the delegates. It was practically unanimous in advising against any allusion to the anti-impeachment senators in the platform, but was ready to support the position of the Radicals on all points involved in the impeachment trial. The New York delegation brought with them an organization of approximately two hundred outsiders who were organized under Thomas G. Alvord as chairman. These men were divided among the various State delegations to work for the nomination of Governor Fenton for vice-president.

Nevertheless the New York delegation was not a unit. The Conservative Republicans of New York occupied practically the entire day of May igth attempting to demonstrate to the various State delegations that New York was not solid for Fenton. A circular signed by Senators Charles J. Folger, Richard Crowley, ex-Senator Thomas J. Murphy, Rufus IV. Andrews, Hugh Hastings and others who called themselves delegates to the convention was distributed. This move did not net them much as the Fentonites sent forth counter circulars showing that the majority of the signers on the first circular had supported Hoffman, the Tammany-Tweed ring candidate for Governor. ${ }^{2}$

Six candidates for vice-president were prominent before the convention: Governor Reuben E. Fenton, of New York; Speaker Schuyler Colfax, of Indiana; Governor Curtin, of Pennsylvania; ex-Vice-President Hamlin, of Maine; Senator Benjamin F. Wade, of Ohio, and Senator Henry Wilson, of Massachusetts.

Prior to the assembling of the convention it was under-

${ }^{1}$ New York Tribune, May 20, I868.

2 Ibid. New York Times, May 20, I868. 
stood that New York would press Fenton until his nomination was clearly seen to be impossible. The delegation refused to indicate a second choice, yet it was understood about the convention that New York, in case of failure to nominate Fenton, would support either Hamlin or Colfax. ${ }^{1}$

The matter of seating the Southern States' delegations was a problem freely discussed prior to the convention. All the Southern States were represented except Texas. The Southern delegates were firm in their belief that they would have no trouble in gaining seats. Many among them declared that they would join the Democracy sconer than submit to what they would consider an insult. Nevertheless, when the temporary organization was completed the New York delegation under the leadership of Charles Spencer forced the admittance of the Southern votes. Great applause attended the action. The New York delegation was unquestionably the leader for the day and lost no opportunity to push Fenton. ${ }^{2}$

Curious was the situation which now existed. Radicals were recognizing in their convention representatives from States which they refused to recognize in Congress. However, the reason for this action on the part of the convention is obvious. Investigation shows that it was around the votes of the Southern delegates that the chief trading in candidates centered. ${ }^{3}$

The temporary and permanent organizations having been effected, respectively, under General Carl Schurz, of Missouri, and ex-Governor Hawley, of Connecticut, on May 2oth, the convention reconvened at ten A. M. on the 2 Ist, and the committee on the platform, after an all-night

${ }^{1}$ New York Times, May 29, I868. New York Tribune, May 19, 1868.

${ }^{2}$ New York Times, May 21, 1868; New York Tribune, May 21, 1868.

${ }^{3}$ New York Times, May 21, I868; New York Herald, May 21, I868. 
session, reported through its chairman, Hon. R. W. Thompson, of Indiana. The chief struggle in the committee had been over the question whether or not to censure the seriators who had defeated impeachment. ${ }^{1}$ The moderates won. Yet when it was seen that Johnson was arraigned, the House of Representatives commended for impeaching him and Johnson declared to have been properly found guilty by the votes of thirty-five senators, without any impugning of the motives of the senators who voted against impeachment, every one appeared content with the compromise. "The friends of conscience and the right of private judgment thanked God it was no worse." ${ }^{2}$

The convention next proceeded to the Presidential nominations. General John A. Logan, in a brief but stirring speech, placed General Grant in nomination. ${ }^{3}$ As each delegation voted solidly for Grant, totaling 650 votes, the wild enthusiasm of the wigwam knew no bounds. It was the first real burst of enthusiasm in the convention.

Attention was next given to nominations for the vicepresidency. The strife between the three leading candidates, Benjamin F. Wade, of Ohio, Schuyler Colfax, of Indiana, and Reuben E. Fenton, of New York, was keen. Governor Fenton was proposed by Lyman Tremaine in a spirited speech. The enthusiasm with which Fenton's name was received placed him third in popular favor. On the first ballot Fenton ranked second to Wade, but fell into third position on the second, where he remained to the end.

1 New York Commercial Adzertiser, May 2I, I868.

2 New York Times, May 22, 1868.

${ }^{3}$ On the day previous a premature attempt had been made to nominate Grant by acclamation but the excitement had been allayed by Lyman Tremaine, who urged that the nomination should proceed with dignity and deliberation. 
General Dodge, of Iowa, who had been balancing his delegation between Fenton and Colfax, on the fifth ballot threw his solid vote of sixteen for Colfax. This acted as a match to oil. When the furore ceased the vote stood-Colfax 522, Fenton 75. and WVade 42. ${ }^{1}$ General Sickles, of New York, then made a motion that the nominations be made unanimous, which was seconded by Ohio and carried.

Although the platform was a compromise between the opposing elements in the party, the advantage lay with the Radicals. The provisions of the Fourteenth Amendment found place: "the guarantee by Congress of equal suffrage to all loyal men of the South" was assured, but at the same time it was asserted that the question of suffrage in all the loyal states belonged to the people of those states alone. All forms of repudiation were denounced and it was declared that taxation should be "equalized and reduced" as rapidly as the national faith would permit. The national debt should be extended over a fair period of redemption. President Johnson and his policy were denounced in no uncertain terms but the Conservative element in the convention and the committee on resolutions was able to modify the stand taken on the impeachment, as has been stated above. The doc-

${ }^{1}$ Table of vote on Vice-President:

\begin{tabular}{|c|c|c|c|c|c|}
\hline Ballot & $I$ & 2 & 3 & 4 & 5 \\
\hline Benjamin F. Wade...... & I 49 & 170 & I 78 & 204 & 199 \\
\hline Reuben E. Fenton ...... & 132 & I 40 & I 30 & I 44 & 137 \\
\hline Henry Wilson & I 19 & I I 3 & IOI & 87 & 6I \\
\hline Schuyler Colfax ...... & I 8 & I 49 & 164 & I 86 & 224 \\
\hline Andrew G. Curtin ...... & 52 & 45 & 30 & & \\
\hline Hannibal Hamlin ..... & 30 & 30 & 25 & 25 & I9 \\
\hline James Speed ......... & 22 & & & & \\
\hline James Harlan ......... & 16 & & & & \\
\hline John A. J. Cresswell ... & I4 & & & & \\
\hline William D. Kelley .... & 6 & & & & \\
\hline
\end{tabular}


trine of indefeasible allegiance, ${ }^{1}$ under which a State clothes with its nationality all citizens no matter where they reside or resident, as strictly followed by Great Britain and other European powers, was condemned "as a relic of feudal times." Rather different from the present idea, foreign emigration was approved and the United States was to be the asylum for the oppressed of all nations.

There were not many, who, under the enthusiasm of the Chicago Convention, stopped to realize that Grant's nomination as a "foregone conclusion" and as an act of the highest political wisdom, acknowledged by Republicans of whatever section, indicated a very marked and rapid change in the sentiment of the Republican party. ${ }^{2}$ A year previous he had been the candidate of only the moderate group of the Republican party. The mildness of his terms to Lee and his insistence that they be lived up to; his report to the President on the condition of the South which Sumner characterized in the senate as a "whitewashing document"; and his apparent wish to make no declaration of principles, which lead to the belief that he was opposed to universal negro suffrage; all these had tended to separate him from the Radicals. It was not until Grant's unfortunate quarrel with Johnson; and his position in the complications growing out of the action of certain district commanders,

1 Westlake, pt. i, pp. 214-33. Scott, Cascs on International Law, pp. 370-412. Jus sanguinis, $i$. e. rule of descent or parentage, is contrasted with $J_{u s}$ soli, $i$. e, , rule of the soil.

2 As early as July 23, I867 the Republican general committee of New York City nominated General Grant for President. That Republican opinion throughout the North was not uniform regarding Grant at that time is shown by the fact that on the same day which saw Grant nominated in New York City, the Republican State Convention of New Jersey voted down by a pronounced majority a similar mot on for the nomination of Grant. (New York World, July 25, 1867.) Greeley, also, was opposed to Grant at this time. (New York Tribunc, Oct. 15, 1867, Nov. 17, 1867.)

${ }^{3}$ Sheridan and Sickles especially. 
together with the consciousness apparently dawning on the Radicals that they had about reached their limit in reconstruction, that the Radicals found in Grant available timber for the Presidency. Up to that point Chief Justice Chase had been the Radicals' favorite candidate.

Henry J. Raymond was open to conviction that the work of the convention was for the best. He was strongly in favor of Grant but with reference to the vice-presidency allowed that "it might not be hard to name other candidates, who would bring to the party, on grounds of locality as well as from personal ability, more of real strength ": than Colfax, although he admitted that his nomination was "eminently judicious". The platform was "as good as we were entitled to expect". However, it would have been better, thought Raymond, to have dropped the subject of impeachment entirely; and in relation to a rapid reduction of taxation and the strictest economy in the administration of the government "a Republican Convention in I868 ought to have been able to present something more effective than promises". The Times, while still a loyal servant, had not forgotten its recent treatment at the hands of the Radicals. In spite of its realization that the financial plank of the Republicans fell short, the Times ably rallied to its support when the Democrats attacked it as meaning nothing. ${ }^{2}$

Horace Greeley observed that it was not necessary to hold a convention to nominate a Republican for President." As for Schuyler Colfax ${ }^{4}$ he considered him the best can-

1 New York Times, May 22, I868.

${ }^{2}$ New York Times, May 25, 1868.

3 New York Tribune, May 22, I868.

${ }^{4}$ Schuyler Colfax was a native of New York City and at the time of election was 45 ycars of age. He had moved with his mother and stepfather to northern Indiana, where first as a clerk then as proprietor of the St. Joseph Valley Register at South Bend, he early entered politics. His sheet controlled the Republicans of St. Joseph County and resulted in his seventh renomination and election to Congress. 
didate, with regrets on grounds of amiability. ${ }^{1}$ " The platform is fair, temperate and firm," said Greeley. "Now let our friends in Congress push on the work of reconstruction ... so that the votes of all the States, if possible, may be cast at the election." 2

The Eacning Post subscribed editorially to all the results of the National Republican Convention in one of its clear, well-balanced, but bloodless statements. It predicted that the campaign would be waged over the matter of equal suffrage. ${ }^{3}$ Three days later the Evening Post, on a closer inspection, decided that the platform was less broad than might be desired on the matter of equal suffrage. It unmercifully suggested that the Republicans should have taken their own medicine by recommending a change of constitutions in the loyal states so that they would read for equal suffrage. ${ }^{4}$

Five months prior to the nominations, the $W$ orld ${ }^{5}$ would have considered the personal availability of the Reptiblicans' ticket a strong one, due to the successful military career of Grant. However, since then he had been convicted of demagogism and duplicity in his connection $1:$ ith the Radicals. Colfax, the World admitted, was a popular man with his party, but one who was a persistent popularity-

'New York Tribune, May 23, 1868.

${ }^{2}$ Ibid.

- New York Ez'ening Post, May 22, I868.

${ }^{4}$ New York Ez'ening Post. May 23, 25, I868. The Philadelphia Press undertook after the National Republican Convention to purify the party. It placed Fessenden, Fowler, Grimes, Ross, Trumbull, Van Winkle, and Henderson on a "Senatorial black-list." Also it read out of the party support the New York Erening Post; Chicago Tribune, Cincinnati Commercial, Providence Joumal, Springfield Republican, Bridgeport Standard, Buffalo Adiertiser, Buffalo Express, and Hartford Courant. The Ea'ening Post took occasion to declare itself an independent organ.

${ }^{5}$ New York World, May 22, 1868. 
hunter and as such ready to change with the strongest wind. The $W$ orld argued that the candidates and platform would be weakened by three things. First, the bloodshed and violence in the South resulting from the Radical policy had shocked the Conservative element of the country. Second, the fact that both candidates coming from the micldle West would tend to alienate the East, especially, as the friends of Fenton, Wilson, Hamlin and of Curtin all had reason to complain. ${ }^{1}$

The Sun in its avowed capacity as an independent organ considered Grant's name a tower of strength to the Republicans. But in viewing the field from its independent standpoint the Sun did not regard Grant as a partisan, nor as the candidate of a political party. ${ }^{2}$ Colfax, "a gentleman of pure character, ${ }^{3}$ of popular manners", was wisely placed on the ticket as a Republican to balance Grant as a War Democrat.

James Gordon Bennett considered that Grant was far stronger than his party, which had been weakened by the Radical excess." "Old Ben Wade" as a bigoted fanatic, Fenton as a failure and Curtin as a very respectable man were politically buried by the Hcrald. Bennett termed the Republican platform as "conveniently evasive and withal as elastic as India rubber"." Nevertheless, the Herald was unqualified in its statement that in the platform the convention had stepped over the boggy places.

Thurlow Weed heartily endorsed Grant and Colfax, but

1 New York World, May 22, I868.

3 New York Sun, June 2, I868.

${ }^{3}$ See Credit Mobilier scandal in Dunning, Reconstruction, pp. 231-3. Rhodes, United States History, vol. vii, ch. xi passim.

- New York Herald, May 22, I868.

5 Ibid., May 23, I868. 
found a platform to which the party would not give entire and cordial assent. ${ }^{1}$ Weed could not see the advantage in a prolongation of the snarl with Johnson. "What the House failed to establish, the voice of Loyal Leagues, of committees, of backwoods gatherings and even of a $\mathrm{Na}$ tional Convention cannot dignify." " The defeat of Fenton gave Weed complete satisfaction; he had urged that the Grant ticket be not imperiled by his candidacy.

Among the up-State papers the epitomized sentiment ${ }^{3}$ of the New York City journals was generally made the basis for editorials. The Rochester Daily Democrat considered that the "platform is all that we could wish it to be ". Regarding the defeat of Fenton the Daily Democrat stated the Governor lost because a noisy squad of Weed men pretended that Fenton was not fully supported at home. The declarations of Weed were, without doubt, the truth, the evident wishes of the Daily Democrat ${ }^{5}$ to the contrary notwithstanding. The most flattering and perhaps sincere indorsement of Colfax which appeared in any of the State journals was published by the Buffalo Express.

If strength is needed to be accumulated upon a ticket which General Grant heads, it is to be added by the name of Schuyler Colfax, whose whole record in Congress from the day he entered the House of Representatives until he became again and

${ }^{1}$ New York Commercial Advertiser, May 21, I868.

2 Ibid.

${ }^{3}$ New York City press attitude on May 22, I868: Tribune, "Delighted with the action of the Chicago Convention." Times, "Convention on the whole did its work well." World, "Ticket as a whole is not a strong one." Herald, "Ticket is a strong one." Sun, "To defeat the ticket the Democrats must nominate two of their ablest and most popular men."

* Rochester Daily Democrat, May 22, I868.

${ }^{5}$ lbid. 
again its presiding officer has been among the most brilliant and unblemished in the annals of the national legislature. ${ }^{1}$

The leading Radical organ of the southern tier, the Binghamton Daily Republican, which very frankly classified itself as belonging to the "more advanced school"," had placed Grant at the head of its ticket on February 24, I868, with the explanation that although Grant is not a Radical, so-called, "we trust him implicitly". The Daily Republican was one of Governor Fenton's urgent advocates for vice-president. It argued for Fenton as an able and incorruptible governor who had twice defeated the Democrats of the State against fearful odds. But on Fenton's failure the change to Colfax was made without a ripple of disappointment. ${ }^{3}$ The Broome $W$ eckly Republican reflected the sentiment of the Daily Republican in speaking of Colfax-“"His political opponents can only strengthen his claims by objecting to his politics." 4

To Ellis Roberts, of the Utica Morning Herald, the outlook did not appear so roseate as the majority of Radical journals asserted. Although in the van of the journals which flayed Johnson and his policy the Morning Hcrald appeared to have become suddenly cautious and timid. ${ }^{5}$ To Roberts the election of Grant was a possibility not a probability. As for Colfax the necessity for bolstering the weak spots in his political career were obvious. ${ }^{6}$ It would seem that Roberts read the political barometer aright with reference to New York State, but made his error in interpreting

1 Buffalo Express, May 22, 1868.

2 Binghamton Daily Republican, Feb. 24, 1868.

3 Ibid., May 22, I868.

${ }^{4}$ Broome Weekly Republican, May 27, 1868.

${ }^{5}$ Utica Morning Herald, May 21, 1868.

- Ibid., May 23, I868. 
the rise of Democratic strength in New York as indicative of the situation in the country at large. Roberts followed the New York Times as a political indicator, and apparently was influenced by its hesitating and doubtful approval of the Chicago convention. Yet, prone to display the weaknesses of human nature, he could not refrain from a covert sneer. ${ }^{1}$

That old-time bulwark of Republicanism, the Albany Evoning Joumal, true to its ancient habit, was unrestrained in its enthusiasm over the nomination of Grant and considered his defeat impossible. It gave Fenton poor consolation by pointing out that he should feel proud of the support accorded him for the vice-presidency, coming as it did from all over the Union. ${ }^{2}$ The Evoning Journal rejoiced that the platform endorsed Congressional Reconstruction, but stated that the direct issue in the campaign was the declaration of the platform in favor of the redemption of the national debt according to the terms of its creation. ${ }^{3}$

As typical of the up-State Democratic editorials on the Chicago Convention, the Utica Daily Observer published what might be termed the best example of the manner in which the results of the convention were received. ${ }^{4}$ Said the Daily Observer:

The Radical leaders are experts in the manufacture of flimsy sensations and political claptrap. In the preparation of Brummagen tinsel, meretricious ornamentation, the fripperies, the simulated thunder and lightning, hail and rain of the theaters,

1 The New York Times is the nearest to hesitation and doubt, as is characteristic of it. Utica Morning Herald, May 25, 1868.

'Albany Evening Journal, May 22, 1868.

3 Ibid.

4 See also Rochester Daily Union and Adz'ertiser, May 20, 22, I868. "In the character and capacity of its individual members it is the weakest national convention in the history of American politics." 
they are unrivaled. The cheap exhibitions of pinchbeck patriotism, and veneered honesty, with which they deceive the acidulated old maids, gullible grannies and short-sighted fanatics and bigots, who constitute the basis of their party, are clever specimens of adroit management of puppet shows. Their proficiency in the knavish legerdemain of politics is certainly remarkable: their facile shiftings of the Radical "little joker" uncler the thimble-upon which the people stake their money and lose-are marvels of manipulation. We wonder at the verdancy of those that allow themselves to be bamboozled by this jugglery; while we are disgusted with the cant, hypocrisy, and insincerity of the performers themselves. ${ }^{1}$

\section{THE DEMOCRATIC STATE NOMINATING CONVENTION}

The Democrats of the State met in State Convention at Tweedle Hall, Albany, on March II, I868, for the purpose of nominating delegates to the Democratic National Nominating Convention. The usual Democratic atmosphere seemed to be lacking, for New York City failed to send contesting delegations. Only one seat was contested in the convention. ${ }^{2}$ William M. Tweed and his disciples seemed to look on the proceedings with the coolness of niasters, ${ }^{3}$ hence the great display of harmony. ${ }^{4}$

\section{${ }^{1}$ Utica Daily Obserier, May 26, I868.}

${ }^{2}$ New York Herald, March.12, 1868. Mr. Jacobs, of Kings, claimed the seat of Mr. Voorbies, of the gth district of Kings. Mr. Jacobs' name had been listed among the delegates, but overnight Mr. Voorhies' name was substituted. Tammany had not forgiven Mr. Jacobs for his effrontery in running for speaker contrary to the machine in the legislature.

${ }^{3}$ New York World, March 12, I868; New York Herald, March I2, I868. Tweed moved the nominations of the vice-pres'dents. Tweef and Richard B. Connolly represented the first district on the committee to select delegates.

4 It appears that the program was arranged the night before in 
The absence of contesting delegations permitted the ieaders to start the convention with the permanent organization. Samuel J. Tilden, chairman of the State central committee, called the convention to order and under his direction the organization was completed without controversy, with Marshall B. Champlain, of Allegany, as president. Champlain's address had for its keynote the thought that Democracy was in the midst of revolution, therefore it must act calmly.

After a recess the convention reassembled at $3: 30 \mathrm{P}$. M. and was addressed by Horatio Seymour, whose speech was the counterpart of the convention proceedings, being noncommittal, unsuggestive and lacking a certain firmness. The tenor of Seymour's address was that the Democrats should present no candidate at this time but go to the National Convention prepared to take advantage of circumstances and issues as they presented thenselves at that time, and support the candidates best suited to present those issues. Seymour devoted the greater part of his address to an able but bloodless discussion of currency, bonds and taxes in which nothing new was presented. ${ }^{1}$ Samuel J. Tilden addressed the convention at length after Seymour. Tilden reviewed the history of the two parties and contended that the policy of the Republicans had been, and was, to impoverish the country, centralize power, paralyze industry, multiply taxation and elevate the negro while degrading the white man. $^{2}$

Tweed's headquarters, Room No. 57-Delevan House. Orders were given out that a free and unrestrained expression of opinion was to prevail. New York Herald, March I2, I868; New York IVorld, March I2, I 868.

${ }^{1}$ New York IVorld, March 12, I868; New YorkTimes, March 12, I 868 .

${ }^{2}$ Ibid. 
The delegates-at-large reported by Delos De Wolf, of the committee to select delegates, were Horatio Seymour, Samuel J. Tilden, Sanford E. Church and Henry C. Murphy. Among the district delegates ${ }^{1}$ appear the names of William

${ }^{1}$ Delegates at Large.

Horatio Seymour; alternate Augustus C. Hand.

Samuel J. Tilden; alternate George W. McLean.

Sanford E. Church; alternate Robert P. Lanning.

Henry C. Murphy; alternate George Law.

Congressional District Delegates.

Ist District, Erastus Brooks, Richmond; John Arınstrong, Queens.

2nd District, James B. Craig, Kings; William Marshall, Kings.

3rd District, Alexander McCue, Kings; James Murphy, Kings.

4th District, Joseph Dowling, New York; Michael Norton, New York. 5th District, William M. Tweed, New York; John Morrissey, New York.

6th District, Emaneul B. Hart, New York; Oswald Ottendorfer, New York.

7th District, Charles G. Cornell, New York; Charles E. Loew, New York.

8th District, Augustus Schell, New York; A. Oakey Hall, New York.

9th District, Albert Cardozo, New York; Edward Jones, New York. Ioth District, Collin Talmie, Putnam; Robert Cochran, Westchester. IIth District, James D. Decker, Sullivan; Enoch Carter, Orange.

I2th District, Henry A. Tilden, Columbia; Charles Wheaton, Dutchess.

13th District, Jacob Hardenburgh, Ulster; George Beach, Greene.

14th District, William Cassidy, Albany; Charles Goodyear, Schoharie. I5th District, Moses Warren, Rensselaer; Emerson E. Davis, Washington.

I61h District, Timothy Hoyle, Clinton; Halsey R. Wing, Warren.

I 7 th District, Samuel B. Gordon, St. Lawrence; Darius W. Lawrence, Franklin.

I8th District, Cornelius A. Russell, Saratoga; Colonel Simeon Sammons, Montgomery.

Igth District, Luther J. Burdett, Otsego; John F. Hubburd, Chenango.

20th District, Allen C. Beach, Jefferson: Lorenzo Caryl, Herkimer. 2Ist District, Francis Kernan, Oneida; George HT. Sanford, Oneida. 22nd District, William F. Allen, Oswego; Charles Stebbins, Jr., Madison. 
M. Tweed, Albert Cardozo, A. Oakey Hall, John Morrissey, Charles E. Loew, all of Tammany fame; William Cassidy, of Albany; Allen C. Beach, of Jefferson; Francis Kernan, of Oneida; Charles Stebbins, Jr., of Madison; Marshall B. Champlain, of Allegany, and William Williams, of Erie. The evening session was devoted to the adoption of a platform which was presented by Mr. A. B. Conger. ${ }^{1}$ The news from New Hampshire, which had elected a Republican Governor two days prior, apparently caused the adoption of a non-committal platform following the cue in Seymour's speech. The platform emphasized the spirit of unanimity which prevailed in the party and scored Congress for its waste, exorbitant tariff, violations of its pledges to bring peace, its prostitution of every branch of public service and for its attempt to depose the President.

A strong feeling prevailed in the convention in favor of taxing United States bonds and paying in legal tenders at maturity, where it was not stipulated that gold should be paid. However in view of the non-committal policy of the convention it was thought unwise to take any action on the question, but leave it open for the Democratic National

23rd District, James P. Haskins, Onondaga; John A. Green, Jr., Onondaga.

24th District, Elmore P. Ross, Cayuga; Charles L. Lyon, Wayne.

25th District, Joseph L. Lewis, Ontario; Lester B. Faulkner, Livings'on.

26th District, Hiram A. Beebe, Tioga; Jeremiah McGuire, Schuyler. 27th District, Marshall B. Champlain, Allegany; Daniel C. Howell, Steuben.

28th District, George W. Miller, Monroe; Henry J. Sickles, Orleans. 29th District, Sherburn B. Piper, Niagara; Henry A. Richmond, Genesee.

3oth District, Joseph Warren, Erie; William Williams, Erie. 3Ist District, Charles H. Lee, Chautauqua; Jonas Button, Cattaraugus.

${ }^{1}$ New York World, March 12, I868; New York Herald, March 12, I 868. 
Convention, which would have a surer light to follow, after the Republican National Convention had met and adopted a platform. ${ }^{1}$

\section{THE DEMOCRATIC NATIONAL NOMINATING CONVENTION}

The Republican National Convention over, the attention of both parties was naturally turned towards the action of the Democratic National Nominating Convention which was to meet in New York City in early July. The Republican journals of the State appeared largely certain of what the Democrats would do at New York, or at least, what they should do. The Democratic journals, on the other hand, failed to exhibit any firm touches in their cautious treatment of the subject. Mr. Chief Justice Chase appeared to be the candidate best calculated to add strength to the Democratic ticket from a Republican viewpoint. ${ }^{2}$ Whether this was a sincere belief is, of course, difficult to judge. Moreover, the honorable position and undoubted character of the Chief Justice gave the discussion of his merits a certain validity. Be that as it may, beyond question there were many Radicals who urged the claims of Chase, as a Democratic candidate, in the hope that if he were nominated his previous state of unstable political equilibrium would react upon him to the advantage of the Radicals. ${ }^{3}$ The Ez'ening Post, however, appeared to be sincere in its suggestions that Chase would make the best Democratic candidate. It stated that it would look upon the nomination of Chief Justice Chase, on a platform of principles prescribed by himself and with a candidate for vice-president his equal in character, as an " event of first-rate im-

1 New York Horald, March 12, I868.

${ }^{2}$ New York Sun, July 7, I868.

' New York Times, June I, I868; June 8, I2, I6, 1868. 
portance in our political history." 1 Should this event occur it would mean a dissolution of parties and a revision on new doctrines. $^{2}$

Theodore Tilton had been Chase's most energetic friend in urging upon the Republicans his nomination for the Presidency until the latter's change to the Conservatives over impeachment. ${ }^{3}$ In spite of the Independent's desertion of Chase in favor of Grant as the Republican candidate, Tilton continued to believe in Chase as Presidential timber, ${ }^{4}$ considering him the best man in the East for the Democrats. Tilton's quixotic attitude towards Chase furnished Dana with a bit of ironic amusement. "Wouldn't it be funny if, after Theodore Tilton's failure to nominate Judge Chase as the Republican candidate, he should succeed in procuring his nomination as the champion of the Democrats." "5

Dana, nevertheless, favored Chase for the Democratic nomination until shortly before the convention. ${ }^{B}$ Thurlow

${ }^{1}$ New York Ev'ening Post, June 9, I868.

${ }^{2}$ Ibid. The Independent, May 21, I868: also held the same view.

"The Independent, May 28, I868. "Half a year ago we urged the Republican party to nominate Mr. Chase, who was then a Radical, rather than Gen. Grant, who was then a Conservative. Since thenGen. Grant has become a Radical, and Mr. Chase a Conservative. Nor is it improbable that the two opposing candidates in the ensuing campaign will be Grant and Chase-the one representing the Radical Republicans, and the other Conservative Democracy. Verily this is a changeful world! Long a partisan of Chase, never a partisan of Grant, we frankly avow that since these two men have so signally changed places we now a thousand times prefer Grant to Chase."

Tilton made the severest criticism on Chase because of his supposed endeavors to defeat impeachment. The Independent, May 21, 1868.

${ }^{4}$ The Independent, May 28, I868; July 16, I868.

${ }^{5}$ New York Sun, May 25, I868.

${ }^{6}$ Ibid., May 23, I868; June 9, I6, 1868. 
Weed, whose favorite editorial diversion was to attack other papers, especially the Tribune, gave sufficient space to decry thoroughly Chase's nomination by any party. ${ }^{1}$ Greeley, who always enjoyed displaying his appreciation of Horatio Seymour, as " a cool, wily, ingenious master of the art of squirting oratorical vitriol," 2 appeared to consider him as an active candidate, especially after the latter's speech of June 25th. The hopes of Chase had been blasted by the "Southern Bourbons".

James Gordon Bennett believed that Chase should be chosen, first in order to insure a civil, rather than a military government, ${ }^{4}$ and second, because he would not be the tool of a legislative clique. ${ }^{5}$ For precisely the same reason, the World did not favor Chase. Although it admired Chase for sticking to his principles, the World did not think that he would receive the nomination or that if he did he would consider himself bound by the convention. ${ }^{6}$

Most of the leading Democratic journals in the country were as disgusted with Chief Justice Chase because of his Presidential mania, as were his former Republican colleagues. The general editorial attitude towards him impresses one with the feeling that he had committed a forgery or a graver felony. ${ }^{7}$

${ }^{1}$ New York Commercial Advertiser, June IO, I868; June II, I868.

${ }^{2}$ New York Tribunc, June 26, I868.

${ }^{8}$ Ibid.

${ }^{4}$ New York Herald, June I6, 1868.

5 Ibid., June I, I868.

- New York World, June I5, 20, 1868.

7 The leading sectional papers of Democratic faith, which denounced the Chase movement in unqualified terms were: Chicago Times; Des Moines (Ia.) Statesman; Columbus Statesman (Ohio organ of Democracy); Wilmington (N. C.) Journal; National Intelligencer (Washington, D. C.) ; Lancaster (Pa.) Intelligencer (Buchanan's mou'hpiece until death); Charleston (S. C.) Mercury. Referred to in New York Commercial Advertiser, June 13, 1868. 
During the formative period of Democratic ideas on the Presidency there appeared to be an intangible yet actual conflict between the East and the West. In the West the followers of Pendleton were opposed to Chase and Seymour, the former because of his past associations and the latter because of his failure to stand for Pendleton's theories of finance. In the East after the Chase movement had passed its zenith, the eyes of practically all were centered upon Seymour as a fighting hope. As the hounds rally to the cry, so did the opposition press, the more Seymour declined to be considered a candidate. The question was repeatedly asked by the opposition: "Will they fall back on Seymour, the old political hack, who with characteristic calculating modesty has already repeatedly refused in advance the barren honors of nomination?"

Seymour's address before the Democrats of New York City on June $25^{\text {th }}$ was variously construed. In his speech he urged upon the Democracy that victory could be had only under Chase. ${ }^{2}$ Seymour on this occasion definitely distinguished between his own and Pendleton's ideas on national finance. The latter's plan called for a redemption of the fourteen hundred millions of government five-twenty bonds in paper. Its aim was to force the bond holders to take their chances with the poor classes. On the other hand, Seymour advocated the theory that nothing should be done to depreciate the value of the government bonds. He stated that deposits in savings banks, approximating five hundred millions, and in life insurance, twelve hundred fifty millions, would be endangered if their securities, namely, government bonds, were not paid, or paid in a debased currency. ${ }^{3}$

1 Broome Weekly Republican, May 27, I868.

- New York Herald, June 26, I868; The Independent, July 9, I868.

${ }^{3}$ New York Herald, June 26, 1868. 
The Herald ${ }^{1}$ and the Tribune ${ }^{2}$ both accused Seymour of feigning to refuse the crown that he might the more safely clutch it. But he was not to be left without those who believed in his sincerity. Theodore Tilton took Seymour at his word and predicted that his refusal would produce a party split. ${ }^{3}$ The Evening Post likened Seymour's speech to an attorney who, having retained an eminent counsel, was told by him that "the case is fatally weak." . . . Then abuse the other side, replied the ready-witted attorney. The World commended Seymour's address but refused to be drawn out on its preference for the Democratic nominee. ${ }^{4}$ Yet it warned the extremists against the foolhardiness of foisting upon the party, candidates and a platform which would not be acceptable to the majority ${ }^{5}$ or would force a departure from the old-established principles of Democracy. ${ }^{6}$

1 New York Herald, June 26, 27, I868. The Herald on July 3, I858, however purported to take Seymour's refusal seriously. "Mr. Seymour we consider, in good faith, out of the fight as a candidate, but in it as an active worker for Chase."

${ }^{2}$ New York Tribune, June 26-July 6, I868.

s The Independent, July 9, I6, I 868 .

- New York World, June 26, I868.

${ }^{5}$ Ibid, June 3, I868. The World believed that the following doctrines should be incorporated in the Democratic platform:

I. Residuary powers of the State governments to remain according to Constitution.

2. The National Debt

(a) was lawful and should be upheld by the full taxing power.

(b) should be handled with discrimination.

(c) should be paid as creditors have naturally construed it.

3. Instant retrenchment imperative.

4. Specie should be the basis of the national currency, but paper money was necessary until the abnormal condition of the country's finance was counteracted.

5. Low tariff.

6 If Pendleton were followed, Democracy would have to break with its ancient hard-money policy. If Chase were followed negro suffrage would be endorsed, which would also be too violent an innovation to be accomplished by a bare majority. New York World, July 2, I868. 
That the Democratic situation was grave and called for skilled treatment was apparently appreciated by the cielegates as they gathered in New York City during the first days of July. The World let no opportunity escape to caution moderation. ${ }^{1}$ Contrary to the situation at Chicago, the battle of intrigue, cliques and sectional animosities was waged around the Presidential nomination, with the platform for an immediate background. The list of Presidential candidates from which the nomination was to be made included the following names: Salmon P. Chase, of Ohio, Chief Justice of the United States, ex-Governor of Ohio, Democratic-Republican, Independent, negro suffragist; Horatio Seymour, of New York, anti-war Democrat, ex-Governor of New York, ancient leader of Democracy, Democratic bondholders' candidate; George H. Pendleton, of Ohio, Copperhead, candidate for Vice-Presidency under McClellan in I864, whose motto was "Greenbacks for the bondholders"; Thomas A. Hendricks, of Indiana, " a second edition of poor Pierce " ; ${ }^{2}$ General Winfield Scott Hancock, of Pennsylvania, the soldiers' candidate, representative of the Conservatives, President Johnson's favorite military man, "because he is more a soldier of the Gecrge Washington type than any other officer in the army "; ${ }^{3}$ General George B. McClellan, of New Jersey, unrequited disciple of Fabius the Cunctator, leader of the movement which carried the States of New Jersey, Kentucky and Delaware against Abraham Lincoln in I864; Reverdy Johnson, of Maryland, conservative, Minister to England, whose vote in favor of the Congressional military system in the South disqualified him with the Western Bourbons; and last but foremost in the opinion of his seconds, Andrew

1 New York World, July I, 2, 1868.

- New York Herald, July 3, 1868.

Ibid. 
Johnson, of Tennessee and the White House, ex-tailor, exUnion State Governor of Tennessee, ex-Congressman, exVice-President of the United States and chief exponent in the arena of "My Policy".

Prior to the convention two other names ${ }^{1}$ had been mentioned more or less extensively in connection with the Democratic Presidential nomination. After Admiral Farragut had refused to have his name considered as a possibility before the Chicago Convention, certain enterprising Democrats, thinking that he was out of harmony with the Radicals, had written to him in Europe asking him to run on the Democratic ticket. Could Farragut be enticed thus, it was thought that his still great popularity as the hero of Mobile would be able to counteract the popularity of Grant, minus the general disgust over the work of Congress in the South. ${ }^{2}$ However, Farragut upset their fond delusion by a peremptory refusal, stating that the honor which he had already received he considered far more than he merited.

On June 30, I868, General Francis P. Blair, of Missouri, wrote to Colonl James O. Broadhead relative to the use of the former's name before the New York Convention. The feasibility of Blair's acceptance was vitiated by the manly

1 Twelve other names received considerable mention among their friends, as the balloting proved. Of these Charles Francis Adams, Minister to Great Britain during the War, alone received no votes in the convention. New York Times, July 3rd, I868. New York Evening Post, July 3, I868.

The other names were Sanford E. Church, of New York; Asa Packer, Joel Parker, and James E. English, each respectively Governor, of Pennsylvania, New Jersey and Connecticut; Senator Doolittle, of Wisconsin; General Thomas B. Ewing, of Kansas; ex-President Franklin Pierce; Mayor Hoffman, of New York City; Justice S. J. Field, of California, and Mr. T. H. Seymour, of Minnesota.

${ }^{2}$ New York Times, July 3, I868. 
stand ${ }^{1}$ he took in stating his exact views on the national situation, $i$. $\mathcal{c}$., that the work of the Radical Congress was unconstitutional and that the new President, if Democratic, should declare the acts of Congress " null and void, compel the army to undo its usurpations at the South, disperse the carpet-bag State governments, allow the white people to reorganize their own government and elect Senators and Representatives." 2 These doctrines were, of coursc, too radical for the Democrats to hope for victory, hence the dropping of Blair's name from consideration.

The above names, aside from those of Chase, Seymour and Pendleton, were ultimately used in a game of chess played for the benefit of the three leading candidates. General Hancock was looked upon as the possible dark horse of the convention, in the event of a protracted tie. ${ }^{3}$ Even the bravest, outside of the immediate coterie of the President's admirers, were fearful of trusting Democracy into the unyielding hands of Johnson. Seymour was the disturbing element of the convention. With the 80,000 odd Democratic voters of New York City, and the New York delegation in his favor, together with his party prominence, he was a factor to be constantly considered, regardless of his protests immediately before the convention. The delegates from the East and South appeared to incline towards Chase. $^{4}$ From the West and Southwest, the delegates were

I See Radical papers on Blair's letter. Violent was the mildest term applied to it. New York Times, July 9, I868. New York Tribune, July 4-6, I 868 .

${ }^{2}$ Letter from Francis P. Blair to James O. Broadhead, Washington, D. C. New York Sun, July 3, I868.

${ }^{3}$ New York Times, July 5, I868. The Times looked on Chase as the probable compromise candidate.

'New York Times, July 6, i 868; New York Herald, July 3, I868; New York Times, July 5, i868. The Times was unkind enough to hint that a large part of Chase's strength in the convention would be 
united for Pendleton and claimed a majority in the convention.

Had "the time-honored principles of the Democratic party" been rigidly adhered to, the suggestion of Francis P. Blair, that the acts of Congress on Reconstruction were unconstitutional, might have prevailed. This would have entailed the repudiation of the Fourteenth Amendment and a number of the acts of the President and Congress, at least from Appomattox. To prevent such a calanity to the Democrats, the Herald, on July 3rd, urgently advocated Chase, ${ }^{1}$ who was represented as the embodiment of constitutional law against military dominance. If the Democrats would accept the constitutional amendments and Chase as a candidate, it was believed that they would win. ${ }^{2}$ The war record of Chase was strong and clear as the financial chief who had made Grant's victories possible.

In reading the newspaper files on the Democratic convention, one is impressed with the fact that there existed among the delegates gathered at New York a general sentiment that the Democrats must go forward and accept new conditions. $^{3} \quad$ The Herald voiced this sentiment on the eve of the convention, as a last admonition. "The talk we hear of the "time-honored principles of the Democratic party' is all clap-trap and moonshine. There has been a

based upon the power of money as a potent agent for conversion and reconciliation. But the operation of the convention proved this charge absolutely false, a fact which does not reflect pleasantly upon the Times.

The Herald called for the following planks in the Democratic platform: acceptance of the amendments, payment of the national debt according to the law, taxation of the bondholders on principles of equal rights.

${ }^{1}$ New York Hera!d, July 3, I868. Ibid.

3 New York Tribune, July 4, I868; New York World, July 3, I868; New York Sun, July 3, I868. 
deluge; the face of the political world is changed. There has been a great revolution. We are entering upon a new epoch. Old things must be done away with, and the Democracy must keep pace with the march of events or they will be broken up, routed and scattered to the winds." 1

The convention assembled on July 4, I868, in the newv Tammany wigwam on East Fourteenth Street, which with its gala trappings and at that time distinctive proportions, made a picture which might well have pleased delegates and citizens alike. Perhaps the latter would not have enjoyed the spectacle so much had they realized that Republicans and Democrats alike had unknowingly contributed to its erection." Many of the delegates as they gathered on this Fourth of July considered it a day which woukd mark a new political epoch. The road appeared to divide in two directions, one leading under Chase to victory and a political revolution, the other under Pendleton either to the disruption of the convention and the party, as at Charleston in I860, or to a crushing defeat at the polls. One Eastern delegate, General John L. Swift, naval officer at Boston, declared before the convention met that the nomination of Pendleton would practically turn the convention into a Grant ratification meeting. ${ }^{3}$ This sentiment, while perhaps extreme, gives an approximate idea as to the Eastern Democratic attitude towards Pendleton.

Mr. August Belmont, chairman of the Democratic national executive committee, called the convention to order at 12:15, Saturday, July 4th. In a short speech he proposed Mr. H. Palmer, of Wisconsin, as temporary chair-

' New York Herald, July 3, I868. The Brooklyn Eagle, the Kings County organ of the Democrats expressed the same idea editorially. Cf. New York Herald, quotation, July 4, I868.

${ }^{2}$ Gustavus Meyers, History of Tammany Hall, passim.

${ }^{3}$ New York Herald, July 4, I868. 
man of the convention, who was received with cheers and made a brief address pleading for harmony. The preliminary test of strength came over the adoption of a resolution offered by General McCook, of Ohio, which called for the use of the rules of the House of Representatives during the temporary organization. After considerable sparring between General McCook. Governor Richardson, of Illinois, Francis Kernan, of New York, "Sunset" Cox, of New York, Erastus Brooks, of the New York Express, and $\mathrm{Mr}$. Green, of Indiana, the resolution was modified so as to call for the house rules in use before I860, plus an amendment which called for the rules which governed the last Democratic National Convention. ${ }^{1}$ The amendment and resolution were then carried, ${ }^{2}$ to the chagrin of Pendleton's supporters, who had hoped to nominate him on a simple majority. The appointment of committees was the cnly other business of importance on the first day. The adjournment was taken until ten o'clock on the following Monday, with the evident hope on the part of all that the excessive hot wave ${ }^{3}$ which existed would sufficiently melt the dispositions of the belligerent delegates, so that the work of the convention might be brief.

Over Sunday the Herald and the Sun continued to advocate Chase, publishing quantities of letters from the South and West tending to show that he was the people's choice. ${ }^{4}$ However, the press elsewhere was beginning to voice a sen-

${ }^{1}$ New York World, July 5, I868; New York Sun, July 6, is68.

${ }^{2}$ The cause of the trouble was the question of the two-thirds rule, which was finally accepted on the matter of voting for the Presidency. The Pendleton men were opposed, having hoped to avoid the twothirds rule in the permanent organization, by paving the way with a simple majority rule in the temporary organization.

${ }^{3}$ Thermometer was at $3^{\circ}$ in shade.

4 New York Herald, July 5, is68; New York Sun, July 4, I868. 
timent among the delegates which boded ill for Chase. The Toledo (Ohio) Blade doubted whether Chase would even receive a complimentary vote and stated that if Pendleton were defeated, the Western men would defeat Seymour and thus force another Polk or Pierce. ${ }^{1}$

Pendleton found it difficult to hide his light under a bushel. Banquo's ghost would appear. Lest the delegates should forget, choice bits of Pendleton's speech in Congress in IS6r on the Crittenden Resolution "2 were furnished by the papers. ${ }^{3}$ A morsel follows:

If these Southern States cannot be consolidated, and if you gentlemen cannot find it in your heart to grant their demandsif they must leave the family mansion-I would signalize their departure by tokens of love; I would bid them farewell so tenderly they would forever be touched by the recollection of it. ... .

Monday morning found the excitement on the increase. After a delegation from the Workingmen's Convention were given seats on motion of General Morgan, of Ohio, Mr. Clymer, from the committee on permanent organization, reported Horatio Seymour for president. Among the vice-presidents, one for each State, the name of IVilliam M. Tweed, of New York, shone with particular brilliancy.

${ }^{1}$ Toledo Blade, editorial quoted in New York Herald, July 5, I868.

2 Senator Crittenden, of Kentucky, advocated by,

${ }^{3}$ New York Herald, July 5, I868.

"New York Herald, July 5. I868. Other items from this address were: "Sir, you will not collect one dollar of revenue-not one dollar [from the seceded States]. Sir, the whole scheme of coercion is impracticable. It is contrary to the genius and spirit of the constitution. If the federal government had the physical power it might overrun and subdue a State; it might subjugate and take possession of it, and then by federal agents, administer the State government-but it would not be the government of this constitution." 
Governor Seymour was escorted to the chair by Governor Bigler, of Pennsylvania, and Governor Hammond, of South Carolina. The ensemble must have been pleasing, one from the hot-house of secession and state rights, another from the home of Radicalism, and the third, the chief of anti-war Democrats. Seymour's address disclosed nothing new. The burden of it was to urge patriotism, as against sectionalism, in party conventions. His text might well have been the Biblical doctrine, "Judge not that ye be not judged." Yet, Radicalism must be denounced, repudiation of the national debt was heresy, and a strict interpretation of the constitution the only protection against military absolution. ${ }^{1}$ Seymour's popularity was manifested by the almost constant applause with which his address was received. The remainder of the morning session was consumed with the reception of resolutions which were referred to the committee on resolutions. ${ }^{2}$

Upon the adjournment of the convention on the second day without either a platform or a candidate, those who had been working for harmony apparently realized the $\epsilon$ nd. The convention appeared to be in a fog. ${ }^{3}$ The failure of

${ }^{3}$ New York $W o r l d$, July 7, I868.

- A lengthy resolution was received and read, to the amusement of the convention, from Elizabeth Cady Stanton, Mrs. Horace Greeley, Susan B. Anthony and Abby Hopper Gibbons, central committee for the Woman's Suffrage Association of America.

${ }^{3}$ New York World, July 6, 7, 8, 1868. In keeping with the procedure at the Chicago Convention, the Soldiers' and Sailors' of Democratic persuasion held a convention in New York City at the Moffat Mansion, Union Square, on Monday, July 6th. General Franklin, of Connecticut, was chairman.. The main business of this convention was to draw up an address to the National Convention. This address was a violent arraignment of the Radicals and urged greenbacks for the bond-holders. Generals Slocum, Gordon Granger, Thomas Ewing and J. A. McClernand acted as a committee to address the National Convention. 
Pendleton's supporters to force the issue upon the evening of the first day or upon the morning of the second day, when they were by far the strongest, gave their disorganized opponents opportunity to unite which meant defeat for Pendleton. ${ }^{1}$ Already, before any results had accrued, the finger of reproach was being pointed towards the New York delegation. The game as they played it was naturally not discovered in all its details until the convention had adjourned. However, on Monday it looked as if Sanford E. Church, who had sprung Tammany's clever coup d'ctat on the unsuspecting convention of $1866,{ }^{2}$ would be played by the New York delegation for the Presidency, apparently to displace Chase, but in reality to take attention away from Seymour until the proper time for him to stampede the convention.

The Herald contemptuously spoke of Church as a "country lawyer and Albany accountant." " He was, nevertheless, a man of considerable ability, young, ambitious and probably honest as politicians go. He later was rewarded by Tammany with the chief judgeship of the New York Court of Appeals. His candidacy appeared serious only because of the strength of the New York delegation and the known possibilities of a stampede. The World, while claiming to stand for no candidate, gave Church's candidacy strong support, in view of the apparent unavailability of Seymour. It urged that the only objection which could be raised against Church was his lack of a national reputation. This, it pointed out, was more than overcome by his pre-eminent abilities. ${ }^{4}$

On Monday before any ballots had been taken the Her-

${ }^{1}$ New York Sun, July 6, I868.

${ }^{2}$ Cf. supra, ch. iv, p. 102 et seq.

${ }^{3}$ New York Herald, July 7, I868.

‘ New York World, July 6, i868. 
ald, to all intents, admitted that its efforts for Chase in behalf of Democracy had been futile. ${ }^{1}$

The truth is, the New York democracy have broken faith with the conservative masses, and have shown themselves to be without intelligence to grasp the situation or courage to indicate their own position. Beginning with Hoffman, and continuing on through Seymour and Belmont down to poor Church, they are all ignorant of the great lessons of the past eight years, butting their copperheads against the idea that the war was unconstitutional, that Lincoln was unconstitutional, that Congress was unconstitutional, and that there is nothing in strict conformity with the constitution except Jeff. Davis, General Lee, poor Pierce, and the old democratic organization, embracing Tammany Hall and the Albany Regency. . . . They do not recognize the fourteenth amendment, as the people demanded they should, nor do they properly denounce the barbarism, brutality and degradation of negro political and social equality in the Southern States. They are bold only in cheating and rascality, and timid where courage is a virtue. The result will be that after exposing their own weakness and cowardice, they will become parties to a platform as unmeaning as that of the mongrel Chicago Convention, and to a nomination that will be miserably beaten in every state in the Union. ${ }^{2}$

The third day's proceedings of the convention were marked by the adoption of the platform. ${ }^{3}$ This, it appears, received the unanimous support of the committee, but not until serious differences of opinion had been overcome. The first and second planks of the platform called for the

${ }^{1}$ New York Evening Post, July 9, I868. Strange as it may seem the Ev'ening Post appears to have believed that the New York delegation was using Church as a stalking horse, while it really planned to nominate Chase.

' New York Herald, July 7, 1868.

${ }^{3}$ New York World, July 8, 1868. 
immediate restoration of all states to their rights in the Union, amnesty for all political offenses and the regulation of the franchise in each State by its respective citizens. In the next four resolutions the following points were advocated: the payment of the public debt, as rapidly as possible, with all funds drawn from the people; equal taxation of every kind of property, including public securities and government bonds; one currency for all; and economy in the administration of the government. Under the head of economy demands were made for a reduction of the army and navy, for the repeal of enactments recalling the State militia into the national forces in time of peace, a tariff for revenue only, abolition of the industrial modes of assessing and collecting internal revenue and the abolition of the Freedman's Bureau and other political instrumentalities designed to secure negro supremacy. The seventh plank urged reform of abuses in administration, the subordination of the military power to the civil power, the expulsion of corrupt men from office and the return to the ancient independence of the judicial and executive departments of the government. The eighth and last resolution declared for the equal rights and protection of naturalized as well as native-born American citizens at home and abroad.

In conjunction with these resolutions the Republicans were impeached for the violation of their Congressional pledge to pursue the War for the sake of the Union, not for party aggrandizement. The nullification of the right of trial by jury, of habeas corpus, of the freedom of speech and of the press, of the presidential constitutional power of appointment, and the institution of arbitrary seizures and star-chamber methods, were chief among the articles of impeachment charged against the Republican party. The platform when presented to the convention was received in toto with the usual enthusiasm. ${ }^{1}$

1 New York World, July 8, i868. 
Before proceeding to ballot, Seymour ruled that, unless objections were at hand, the 1860 rule would be followed, $i$. e., no nomination until a vote equal to two-thirds of the vote of the electoral college had been cast for a candidate. ${ }^{1}$ It required twenty-two ballots to select the candidate for President. Chase hardly figured in the balloting. The names of Hendricks, Hancock and Pendleton proved to be the fighting centers. On the eighth ballot New York began to show its hand by dropping Church and voting solid for Hendricks, for whom it continued to vote until the twenty-second ballot. It would seem, viewed in the light of later events, that the New York delegation, after seeing the futility of using Church for the purpose, hit upon Hendricks as a candidate of sufficient strength to balk the nomination of another until, the convention having become weary, the psychological moment arrived to bring forth its real candidate, Horatio Seymour. On the fourth ballot Seymour's name had been proposed, but he absolutely refused to permit its use. But on the twenty-second ballot Ohio started a landslide for Seymour by giving him its solid vote. ${ }^{2}$ Seymour again refused to permit the use of his name. However, the tide was too strong to be stopped. The final result of the twenty-second ballot gave Horatio Seymour every vote of the convention, 317 .

Due to the protracted struggle over the Presidential nomination all hands appeared anxious to end the convention, hence the nomination of a vice-president gave little trouble. When the name of General Francis P. Blair, ${ }^{3}$ of Missouri, was proposed, the popular chord of the

${ }^{1}$ New York World, July Io, I868; New York Tribune, July ıo, I868.

${ }^{2}$ New York World, July 8, I868. It was claimed that Tilden through a bargain with certain leading members of the Ohio delegation induced it to lead the movement for Seymour. See Alexander, A Political History of the State of Nezw York, vol. iii, p. 203.

${ }^{3}$ General Blair did good service in the field under Grant around 
convention seemed to be touched and his election was made unanimous at the end of the first roll call. ${ }^{x}$

Seymour accepted the nomination on the following evening. He stated to the meeting that he found himself unable to resist "the overwhelming tide that is bearing us on to a great political change." 2 Samuel J. Tilden was accused of having conspired to nominate Seymour from the start. Tilden, however, wrote a letter denying the frequent imputations that he was responsible for Seymour's nomination, although admitting that he would have been glad of it had the nominee been willing. ${ }^{3}$ An interesting side light is thrown by Gideon Welles on Tilden's part in the nomination of Seymour, which affords a possible clue to Tilden's course in the convention. Welles wrote:

Blair tells me that Samutel Tilden wanted to be the candidate of the Democrats for President. It is hardly credible, and yet in that way, better than any other, can his conduct and that of the New York Democratic politicians be accounted for. $\mathrm{He}$ and they had professedly no candidate-could name nonewere, while holding the reins, as meek in their professions as Urial Heep, waiting for others to move, and similar silly pretensions were made when the country was in agony. ${ }^{4}$

The Chief Justice must have felt truly grateful to the

Vicksburg and under General Sherman on his march to the sea. Blair's military career was at the outset threatened, due to his trouble with General Fremont when the latter commanded the Department of Missouri. Blair came from pure Democratic stock, but he had acted with the Republicans and Unionists from 1854 to the death of Lincoln from which time he had followed a fitful course.

1 Other names proposed were General McClernand, General Thomas

B. Ewing and Hon. A. K. Dodge, of Iowa.

${ }^{2}$ New York Herald, July II, I868.

${ }^{3}$ John Bigelow, The Life of Samuel J. Tilden, vol. i, pp. 2I I-2I2.

+The Diary of Gideon Welles, vol. iii, p. 446. 
convention for its kind remembrance. A curious chapter on Chase developed Thursday, July 9th, the last day of the convention. On that morning Samuel J. Tilden called a meeting of the New York delegation. ${ }^{1}$ Horatio Seymour was present and strongly advocated turning the support of New York from Hendricks to Chase. In this he was bitterly opposed by State Senator Murphy, of Brooklyn, who defied Seymour to name any States that Chase would carry. Seymour stated that he had consulted with various of the western and central delegations of the State before making his appeal for Chase. Murphy was forced to dodge the question when Seymour asked if his home city, Brooklyn, would not support Chase. The four district delegates from Brooklyn stood for Chase. General John A. Green, of Onondaga, also opposed Chase, but Seymour discounted his opposition by showing that Onondaga never gave a Democratic majority. On the vote Senator Murphy and General Green, aided by Albany Democrats, were able to poll 27 votes for Hendricks; but Seymour, aided by Peter B. Sweeny and the solid New York City delegation, except John Morrissey, who favored Pendleton, went for Chase, giving him 36 votes. It was thus agreed that the name of Chase should be placed before the convention that morning at the earliest possible moment. Precisely why this was not done, does not appear. The failure to present Chase's name may possibly be accounted for by the violent opposition with which it was received by General McCook, of the Ohio delegation when sounded on the matter. A minority of the Ohio delegation, including Vallandigham, however, agreed to stand by Chase, as did a considerable number of the Pennsylvania delegates. It would seem that this antici-

${ }^{1}$ New York Herald, July ro, i868. Cf. New York Evening Post, July 9, I868; Cf. New York Times, July 9, I\$68. 
pated move in favor of Chase on the part of New York had a direct bearing on the action of Ohio in attempting to stampede the convention for Horatio Seymour. We are led to believe there was constant double dealing on the part of the New York delegation. Certainly that was the distinct opinion which prevailed among the Southern and Western delegates. ${ }^{1}$

The New York Herald was inconsolable over its failure to nominate Chase. It continued to think that the majority of the independent thinking men favored Chase and that the nomination of Seymour was the result of trickery at the hands of Tammany and the Albany Regency." The nomination of Seymour gave Grant the election ipso facto." Although there had been a strong movement on foot to obliterate the old party lines and combine the several conservative elements against Radical misrule, the nomination of Seymour, thought the Herald, resolved the contesi into a choice between those who had stood for Union and those who had supported disunion. ${ }^{4}$

The World cordially indorsed the financial part of the Democratic platform as it did the portion relating to negro suffrage and Radical Reconstruction. But it called the tariff plank of the platform a muddle. It failed to see under the wording of the platform-" a tariff for revenue upon foreign imports and such equal taxation under the internal revenue laws as will afford incidental protection to domestic manufactures"-how internal taxes were to protect without discriminating. ${ }^{5}$ Regarding the nomination of Sey-

${ }^{1}$ New York Times, July 9, I868; New York Evening Post, July 9. I868; New York Sun, July I0, I868. The Sun spoke of Pendleton's being crowded from the field as illustrative of a "system of tactics that has hardly a parallel in the annals of party warfare."

- New York Herald, July Io, I868.

${ }^{3}$ Ibid.

"Ibid., July II, I868.

${ }^{5}$ New York World, July 8, I868. 
mour and Blair, the World waxed enthusiastic. First, Seymour was the greatest statesman of the Democratic party; secondly, he had a strong grasp on the questions which related to the strengthening of the national finances; and lastly, he had always been such a thorough and consistent Democrat, and his party popularity and influence were so great, that he alone possessed the requisite moral weight to adapt Democracy to the altered condition of the country. ${ }^{1}$

Assuming for the moment that Seymour had been elected in I868, the logic which the World used in explaining its opposition to Chase appears sound. Had the Chief Justice been elected he would have been regarded as a renegade by the Senate, and the Democrats would have distrusted him as a Radical. Had he dared to make the necessary concessions to the Radicals, the party which had elected him would have thought him false to his principles. ${ }^{2}$ Seymour. even though he had advocated the nomination of Chase, had been such a staunch unswerving Democrat that any concession he might make would be accepted by his followers as a necessity, rather than an evidence of partiality or a sign of falsity.

But Charles Dana could not see the force of this logic. On July Ist, Chase had issued his final declaration of principles which embodied States rights, suffrage to all citizens regardless of race, all disabilities to be removed from the South, and sound money. ${ }^{3}$ Pointing to this platform and to the character of Chase, Dana felt obliged to confess that the doctrine and the man were "considerably in advance of the old-fogy Democracy of the present day." To Dana, Chase appeared as "a great, progressive states-

${ }^{1}$ New York Herald, July IO, 1868.

2 New York World, July ı, I868.

3 New York Sun, July 7, I868. Sce platform. 'Ibid. 
man" who had been rejected by the Tammany Hall convention because of his Radical associations. The vast accession of strength which Chase would have brought from the Radical party, would be realized by the Democrats too late. ${ }^{1}$

The Pendletonites attempted to cover up their chagrin after the nomination of Seymour by making public a letter written on June 25, I868, by Mr. Pendleton to Washington McLean, proprietor of the Cincinnati Enquirer, prior to the latter's departure for the convention. In this letter Mr. Pendleton professed to feel that Seymour was the foremost man in the Democracy. "I would rather trust him than myself with the delicate duties of the next four years ... Make him feel ... that I an ready-anxious to give up the nomination to anybody who can get one single vote more than myself." 2 This letter may have been written for the exact purpose which it served; a more charitable view, such as the $W$ orld took, ${ }^{3}$ makes the letter an honor to Pendleton. But as the game of politics is played, one must beware of political letters, even under the guise of personal correspondence. How convenient it is to have every possible avenue guarded by a letter which is calculated to serve a definite contingency.

Seymour " is the fair representative of the average sentiments of the Democracy upon all the leading issues of the canvass," was the best the Sun had to offer, although it admitted his distinguished position in the party and his popularity east of the Alleghenies.. ${ }^{4}$ General Blair was characterized as a man of fair talents and great force of

${ }^{1}$ New York Sun, July 7, I868.

${ }^{2}$ New York Herald, July ı, I868.

${ }^{3}$ New York World, July I0, I868.

${ }^{4}$ New York Sun, July Io, I868. 
character, who in his recent letter had placed himself on higher grounds than the Democratic platform, ${ }^{1}$ but " in politics unsound, extreme and violent"."

This was the attitude the Evening Post assumed on Blair, ${ }^{3}$ while it considered Seymour the creature of advisers, for the most part bad advisers. The Democrattc platform set the two parties in fair open opposition upon the principal questions before the country, $i . \mathcal{c}$., the question of Reconstruction and the question of the payment of the debt. ${ }^{4}$ The Evening Post saw in the financial plank of the Democratic platform, repudiation, which was calculated to carry the supporters of Pendleton and in addition win over the Butler faction of the Radical party which was out of accord with Grant and Radical principles. ${ }^{5}$

There was no ambiguity in the succinct sentences of the Democratic platform on the financial question, thought the Times; the principles were those of which Pendleton was the exponent. While the Times advocated no candidate for the Democrats at any time, it was obvious that it thought Chase would make the strongest run against Grant. After matching Seymour's war record with that of Grant and pointing to Blair's revolutionary letter, the Times concluded that the candidates and ticket inspired no apprehension of success. ${ }^{6}$ The attitude of the Tribune on the Democratic candidates and platform was similar to that of the Times, though naturally sharper. Horace outdid himself

${ }^{1}$ New York Sun, July Io, IS6S.

${ }^{2}$ Ibid., July I I, I868.

${ }^{3}$ New York Evening Post, July I I, I868.

'New York Evening Post, July IO, II, I868.

${ }^{5}$ See New York Sun, July 8, 1868 , for a comparison of the Dem. and Rad. Nat. platforms.

${ }^{6}$ New York Times, July I0, 1868. 
in reviewing Horatio's past. ${ }^{1}$ But Greeley was outdone by Theodore Tilton, who was extremely unpleasant in his remarks on the platform and candidates. Rebellion was in the air-for proof see the Democratic platform. ${ }^{2}$ Tilton took occasion to disagree with the general view that Seymour's nomination was the result of underground machinations on the part of the New York delegation. He maintained that Seymour's refusal to run was sincere. This, Tilton sympathetically explained, was due to signs of a gradually approaching insanity. Also, the New York delegation was sincere in its failure to advance Seymour, who was simply hit by lightning under the deft manipulations of General McCook. Pendleton was the real power of the convention, being sufficiently strong to block the candidacy of any other man and strong enough to give the nomination to anyone he chose; hence Seymour was his candidate, the platform being Pendleton's on its face. "Chase was on everyone's lips but in no one's heart." ${ }^{3}$ was the sole comfort Tilton had for his quondam candidate.

The line of comment of the up-State Radical papers was perhaps more scathing than that adopted by the city journals. "The attitude assumed by the Democratic party is a fearfully fatal one. . Never did a party fling away so glorious an opportunity. . . . the Democratic party is imbedded in political iniquity," sums up the Evoning Journal's comment on the convention. The Utica Morning Herald declared that the "Artful Dodger" himself would

${ }^{1}$ New York Tribune, July 3-11, I868, cf. Ioth.

${ }^{2}$ The Independent, July 16,1868 . Tilton's opening shot on the results of the Democratic convention follows: "Audacity, violence, and revolutionary frenzy blew their breath so furiously through the scrannel-pipes of Tammany that already the whole land rings with the echo."

${ }^{3}$ The Independent, July 16, 1868 . 
have found it difficult to pen a more dubious document. "It is the attempt of a set of hungry, cunning and unscrupulous politicians to overreach and head off each other, . . at the same time struggling to conceal the fact of their mutual hatred." 1 Carroll E. Smith termed the declaration of principles as honest and manly but at the same time outrageous and disgraceful. ${ }^{2}$ The Syracuse Daily Standard contented itself with pointing out the inconsistencies between Seymour's public addresses before the convention and the Democratic platform. The most glaring inconsistency was Seymour's statement that the payment of the debt would fall on the future generations, while the platform stood for payment of the debt as rapidly as was practicable. $^{3}$ The Rochester Daily Democrat ${ }^{4}$ and the Buffalo Express $^{5}$ found the Democratic National Convention a medley of exploded ideas, dogmas, platitudes and fallacies, with the Copperheads in control.

But from a close examination of the up-State Democratic journals one fails to find aught but joy over the results of the Democratic National Convention. "He is the man for the crisis," said the Argus. ${ }^{\circ}$ The Utica Daily Observer considered Seymour the natural candidate, being the wisest before, during and after the war. ${ }^{7}$ It remained, however, for Mr. W. W. Green, editor of the Courier and Union, to express adequately the Democratic exuberance. "With that joy with which a bridegroom clasps his newly-wedded bride, with that joy with which the Pilgrims of old, toiling,

${ }^{1}$ Utica Morning Herald, July 9, I868.

${ }^{2}$ Syracuse Daily Journal, July 9, I 868.

${ }^{3}$ Syracuse Daily Standard, July I I, I868.

- Rochester Daily Democrat, July 9, I868.

${ }^{5}$ Buffalo Express, July 9, II, I868.

- Albany Argus, July io, I868.

'Utica Daily Observer, July io, 1868. 
weary and footsore, first beheld the New Jerusalem, with that joy with which poor weak humanity clings to its Saviour for support, we, an overburdened, oppressed and weary people, groaning under the sweat of a load of indignities, long since too heavy to be borne, proclaim to-day as our standard bearer in the great coming contest of liberty, justice and freedom, with oppression, injustice and inhumanity, the name of Horatio Seymour, the frank, fearless, candid, self-denying man, the bold, intrepid leader, the eminent scholar, and the distinguished statesman of the Empire State." 1

'Syracuse Daily Courier and Union, July Io, I868. 


\section{CHAPTER XII}

\section{The State Connentions of New York in i868}

THE REPUBLICAN STATE NOMINATING CONVENTION

DUE to the overshadowing of the greater Democratic National Convention which was in session at the time, the Republican State Nominating Convention which met at Syracuse on Wednesday, July 8, I868, excited little interest among the papers or the people at large. Although Fenton's defeat in the National Republican Convention of the previous May was sufficiently prominent to disturb the State convention, in reality the latter convention was little more than a ratifying body for the former. Nevertheless, since the major State officers were to be nominated, a certain amount of serious attention was devoted by the leaders.

Among the more prominent in attendance were John L. Parker, of Cayuga; Judge Robertson, of Westchester; Hamilton Harris, Judge Low, Chauncey Depew, General Merritt, General Cochrane, Ben Field, Waldo M. Potter, J. W. Kimball, of Franklin; C. W. Godard, Senators Chapman, Hale and Palmer, Waldo Hutchins, Charles Spencer and Thayer Francis, of the Troy Times. Horace Greeley was not in attendance, but sent up John Russell Young, of the Tribune office, to represent his interests.

The delegates to the State convention came for the most part uninstructed and appeared to be far from zealous in anyone's interest. The leading candidates for Governor included the names of John A. Griswold, of Troy; Lyman Tremaine, of New York; Marshall O. Roberts, of New 
York; Charles H. Van Wyck, of New York; Stewart L. Woodford, of Kings, and Horace Greeley. Greeley furnished the surprise of the convention, turning up at the eleventh hour as a candidate for the governorship. His friends were led by Governor Fenton, who controlled the convention. The candidacy of Greeley considerably disturbed conditions, for most of the country delegates bad decided upon Griswold or Tremaine, with chances favoring the former. For the other offices the competition was not keen and the slate was unsettled. Mr. Van Wyck in a letter dated July 7 th, addressed to the Hon. E. M. Madden, declined to run for Governor, reducing the candidates to five.

Hamilton Harris, chairman of the State committee, called the convention to order at noon on the 8th. On motion of Mr. E. M. Madden, of Orange, Mr. Henry Smith, of Albany, was made temporary chairman. The preliminary organization of the convention then followed and produced the annual split between the New York City Radicals and Conservatives. It would appear, however, that the Twenty-third Street organization had acquired wisdom. It sent no contesting delegation, but did send a committee to ask for a reorganization. ${ }^{1} \quad$ Mr. Younglove moved that a committee composed of Messrs. Joseph H. Ramsey, J. C. Bancroft Davis, Walter L. Sessions, Mathew Hale, C. M. Demson, Roswell Hart and C. H. Chapman be appointed to hear the facts on the trouble between the rival New York City delegations and report to the convention as soon as practicable. This was strenuously opposed by Charles Spencer, leader of the Radical faction from the City. He objected to the resolution taking the naming of the committee away from the chair, and especially to the name of Mathew Hale, of Essex, - whom he accused of

${ }^{1}$ New York Times, July 9, I868. 
having done all in his power to thwart Governor Fenton's administration. Mr. Hale immediately replied, flatly denying Mr. Spencer's charge and refusing to serve on the committee. Mr. Sessions likewise declined to serve. For a time it looked as if the first day of the convention would be entirely given up to a settlement of the New York feud. Attempts by Waldo Hutchins and Mr. E. M. Madden to side track the controversy failed. But Mr. A. X. Parker succeeded in having a resolution passed which called for a committee of two from each judicial district except the first. This committee ${ }^{1}$ was instructed to report at the next State convention. After announcement of the committees the convention adjourned until $3: 30 \mathrm{P}$. M.

At the afternoon session the rules of the last assembly were adopted upon motion of Chauncey Depew. For permanent president, General John Cochrane was reported by General Gates of the committee on permanent organization. No opposition developed and General Cochrane was nominated. The committee on contested seats reported adversely to the contestants in each case. But one important item of business now intervened between the real business of the convention. A resolution was offered and adopted, ${ }^{2}$ after an attempt had been made to place it upon the table, which aimed to equalize the representation in future Republican State conventions. It provided that there should be one additional delegate from each assenrbly district and one additional delegate from said district for every $I, 500$ voters or fraction of 1,500 over $750 .^{3}$

${ }^{1}$ Committee E. M. Madden, of Orange; Thomas W. Jackson, of Albany; A. X. Parker, of St. Lawrence; T. W. Dwight, of Oneida; Norwood Bowne, of Delaware; Lewis E. Smith, of Livingston; and Norman Allen, of Cattaraugus.

$2 \mathrm{By}$ a vote of 208-152.

s New York Tribune, July 9, 1868. 
On motion of Charles Spencer, of New York, the convention moved to an informal ballot for Governor. Mr. George W. Demers, of Rensselaer, briefly but warmly nominated John A. Griswold, of Troy; the nomination was seconded by Mr. Hart, of Monroe. Mr. Blank proposed the name of Lieutenant-Governor Stewart L. Woodford. The third and last nomination was made by Chauncey M. Depew, who in placing the name of Horace Greeley before the convention referred to him as towering above all other men in the Republican party in point of intellect and services. $^{1}$ Charles S. Spencer seconded Greeley's nomination. Depew's etulogy of Greeley elicited a storm of applause which contrasted strongly with the number of ballots which Greeley received. Was Greeley led into an ambuscade as many of his friends claimed? The question arises as to the motives of Depew and Spencer in their support of Greeley at this time, both having previously suffered from Greeley's caustic pen. Two answers suggest themselves: that it was part of a plan to pass the Republican state control to New York City; or, what is more credible, that it was a patriotic effort to support a man who was in their opinion best qualified for the office. We leave the question. The informal ballot gave Griswold 247, Greeley 95, and Woodford 36 votes. Immediately the nomination of Mr. Griswold was made unanimous.

For lieutenant-governor, Alonzo B. Cornell, of Ithaca, was placed in nomination by Mr. Selkreg, of Tompkins. Mr. August Frank, of Wyoming, and Gen. Franz Sigel also were proposed, but on the first ballot Alonzo B. Cornell received 219 votes to 88 and 6 for Mr. Frank and Gen. Sigel respectively. Mr. Cornell's nomination was then made unanimous. Mr. Alexander Barkley, of Washington, was

${ }^{1}$ New York Herald, July 9, 1868. 
nominated for canal commissioner by acclamation. Colonel Edward Lansing, as chairman for a subcommittee from the Soldiers' Organization was presented and as a representative of that body requested the nomination of Hon. Henry A. Barnum as candidate for inspector of State prisons. His request was granted by acclamation. Charles S. Spencer then proposed Colonel Lansing as the candidate for clerk of the Court of Appeals, but the motion to substitute the name of Campbell H. Young was carried by a vote of $20 \mathrm{I}$ to 27 , and the nomination made unanimous. For electors-at-large, Mr. William R. Stewart, of the committee to select electors-at-large, reported the names of Marshall O. Roberts, of New York, and Henry R. Seldon, of Monroe. The report was adopted but not before an attempt was made to substitute the name of Horace Greeley for that of Roberts. The adoption of the resolutions and the report of the names of electors ${ }^{1}$ and the members of

1 Electors reported by the respective Congressional Delegations.

\begin{tabular}{|c|c|c|c|c|c|}
\hline I st & 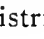 & Curtis & Izth & & \\
\hline 2nd & “ & Jacob Worth & I8th & “‘ & George S. Batchellar \\
\hline 3 rd & ، & E. A. Steedwell & Igth & “ & James H. Graham \\
\hline $4^{\text {th }}$ & ، & Samuel S. Wyckoff & 20 th & ، & Morris Winslow \\
\hline 5 th & “ & Moses H. Grinnell & 2 Ist & “، & Patrick C. Costello \\
\hline $6 \mathrm{th}$ & ، & Charles S. Spencer & $22 \mathrm{nd}$ & ، & Robert Stewart \\
\hline 7th & “ & Alex. T. Stewart & $23 \mathrm{rd}$ & “، & Edward B. Judson \\
\hline 8 th & “، & Frederick Schuetz & $24^{\text {th }}$ & “ & H. H. Guthrie \\
\hline gth & “ & H. C. VanVorst & 25 th & “، & Samuel Jane \\
\hline th & ، & Ambrose L. Rider & 26 th & “، & Charles M. Titus \\
\hline th & “ & Elisha P. Wheeler & 27 th & “ & Horace Bemis \\
\hline th & “ & George Innis & 28 th & ، & Edwin R. Reynolds \\
\hline & ، & Thomas Cornell & 29th & ، & Stoughton Pettibone \\
\hline & ، & Charles H. Adams & 3oth & “ & M. Weicrick \\
\hline & ، & Geo. W. Demers & 3ist & ، & Norman M. Allen \\
\hline 6 th & " & Moses R. Platt & & & \\
\hline
\end{tabular}


the State committee ${ }^{1}$ furnished the last item of the convention's business.

The platform was an echo of the Chicago platform. ${ }^{2}$ The Congress which had accomplished Reconstruction was ranked with that which had decreed the downfall of slavery. The soldiers and sailors were thanked for their support of the Union and immediate payment of the bounties together with generous financial measures in their behalf were urged. A general reduction in the cost of administration was demanded together with a return to specie payment. The full payment of the national debt was urged as alone consistent with the national honor. Generous naturalization and immigration laws should be enacted and the protection of the American law extended the world over to naturalized citizens no matter where born. General Grant and Schuyler Colfax were lauded, as was the administration of Governor Reuben E. Fenton.

The editorial opinion on the work of the Republican

${ }^{1}$ The State Committee.

\begin{tabular}{|c|c|c|c|c|}
\hline \multicolumn{2}{|c|}{ Ist District-J. B. Cooper } & \multicolumn{3}{|c|}{ I7th District-E. A. Merritt } \\
\hline 2nd & S. B. Dutcher & I 8 th & “ & H. M. Crane \\
\hline “ & Benjamin Wilson & Igth & “ & L. Kinsley \\
\hline ، & Joshua G. Abbe & 20 th & “ & E. R. Livingston \\
\hline “ & Waldo Hutchins & $2 \mathrm{Ist}$ & “ & L. Blakesley \\
\hline “، & Sinclair Toucey & $22 \mathrm{nd}$ & “ & B. G. Fort \\
\hline “ & Benjamin Merritt & 23 rd & “ & James Terwilliger \\
\hline ، & W. P. Esterbrook & 24 th & ، & George J. Post \\
\hline “ & Ira O. Miller & $25^{\text {th }}$ & “ & Thomas Hillhouse \\
\hline " & James W. Husted & 26 th & “ & Thomas C. Platt \\
\hline “ & H. R. Low & 27 th & “ & H. H. Hull \\
\hline “ & Cornelius Esseltyne & 28 th & “ & Lyman M. Newton \\
\hline “، & Joshua Furro, Jr. & 29 th & “، & D.A.VanValkenburg \\
\hline “ & Hamilton Harris & 30 th & " & George G. Newman \\
\hline “ & A. D. Wait & 3Ist & “ & Henry C. Luke \\
\hline ، & Samuel Root & & & \\
\hline
\end{tabular}

${ }^{2}$ New York Times, July 9, I868; New York Tribune, July 9, I868. 
State convention was stereotyped. The Times pointed out the six years of successive service in the House with which Griswold was credited, also his extensive executive and administrative experience in connection with the large business interests with which he was connected at Troy. ${ }^{1}$ His election was not a matter of doubt. Anticipating the Democratic attack the Times attempted to minimize the fact that Griswold had been originally elected to Congress as a War Democrat, by showing that he had always acted with the Republican party in Congress. ${ }^{2}$

James Gordon Bennett refused to whitewash the weakness of the Radical State convention. He boldly stated that the convention was not calculated to inspire confidence in view of the irrepressible "cat and dog" row between the rival New York City factions. If the Democracy would nominate a proper candidate, Griswold and the entire ticket would be defeated by a larger majority than the Radicals of the previous year. ${ }^{3}$

If Horace Greeley was chagrined over the deceit practised upon him and his consequent defeat in the Republican convention; as we have the right to assume, not the slightest trace appeared in the columns of the Tribune. "We believe this [Griswold] an eminently wise and fortunate selection. . . He has never yet been defeated and he can-

1 Head of a large iron manufactury, president of a bank and director in several railroads, factories and transportation companies. First rate business capacity, elegant agreeable manners, extensive connections. New York Sun, July 9, 1868.

${ }^{2}$ New York Times, July 9, 1868.

${ }^{3}$ New York Herald, July 9, r868. Incidentally the Herald found much amusement in the failure of Greeley to win the Republican nomination. New York Herald, July Io, 1868.

The New York Times, July 9, I868, was apparently sympathetic with Greeley in his ambuscade and rout, for it thought that the result would have been different had Greeley been there in person. The Nation thought likewise. July I6, 1868. 
not now be." 1 The Tribune further echoed the Troy Times, Griswold's home paper, which accredited to Griswold great personal as well as political popularity and remarkably apt executive and administrative abilities. ${ }^{2}$

The Evening Post gave a qualified assent to the nomination of Mr. Griswold. It was inclined to believe that he would be of some positive good to the State if elected, were it not for the fact that the State constitution makes a figurehead of the Governor. The platform, although simply an echo of the Chicago platform, would not suffer, because the Democratic State platform would likewise ignore State matters in endorsing the New York platform. ${ }^{3}$ The Commercial Advertiser gave more attention to the Republican State convention than any of the other City papers. It believed that success was more certain under the leadership of Griswold than under that of any one else. But it took issue against the bad counsels that had prevailed at Syracuse. "Those eminently pure patriots, Charley Spencer and Waldo Hutchins", were accused of having caused the disruption of the Republican ranks of New York City, producing a decrease of votes from 36,000 to $18,000{ }^{4}$

The World editorially took but slight notice of the Republican State convention. It purported to consider the nomination of the opulent and amiable Griswold as a fair exchange for the Republican State campaign expenses. As for the platform it " cheers Fenton as he sails to glory on his mattress; invites the general government to take an interest in the Erie canal frauds; recognizes the corruptionists

1 New York Tribune, July 9, 1868.

${ }^{2}$ Troy Times, July 8, I868. Quoted in New York Tribune, July 9, I 868.

${ }^{3}$ New York Evening Post, July 9, I868.

${ }^{4}$ Votes of 1864 and I867. New York Commercial Advertiser, July 9. 1868 . 
of Congress as praiseworthy brethren of the Albany ring; and thanks the Rump for doing 'persistently and firmly' all that it has utterly failed to do." " In its next issue the World began its campaign against Griswold by showing how he had voted in Congressional committee to profit at the expense of the government in connection with his governmental iron contracts. ${ }^{2}$ The Sun refused to commit itself as to the wisdom of the selection of Griswold. It believed that Frederick A. Conkling, ${ }^{3}$ Horace Greeley or Marshall $O$. Roberts would have pulled stronger in the eastern counties of the State, where the Democrats could count upon a roo,ooo majority. ${ }^{*}$

Even more noticeable than the failure of the Republican State convention to arouse interest among New York City journals was the lack of interest displayed in it by the upState papers. Among the Republican organs the Rochester Daily Democrat alone raised a voice of dissent to the nomination of John A. Griswold. It thought that the wisest action for the convention would have been the nomination of Horace Greeley, but agreed to support Griswold as second best. ${ }^{5}$ Roberts contented himself with emphasizing the unanimity of the Chicago and Syracuse conventions as contrasted with the bitterness of the Democratic National convention then in session. ${ }^{6}$ Of the Democratic up-State journals the Argus advanced the most noteworthy opinion; which was that Griswold was nominated by the aid of, and would be beaten by the Fentonites. ${ }^{7}$

${ }^{1}$ New York World, July 9, I868.

2 Ibid., July io, I868.

${ }^{3}$ Brother to Roscoe Conkling.

${ }^{4}$ New York Sun, July 9, I868.

${ }^{5}$ Rochester Daily Democrat, July 9, I868.

${ }^{6}$ Utica Morning Herald, July 9, 1868.

${ }^{7}$ Albany Argus, July 13, I868. 
THE DEMOCRATIC STATE NOMINATING CONVENTION

The Democrats of the State according to the time-honored custom waited until September before holding their State convention, which met at Tweedle Hall, Albany, September 2, I868. The convention assembled under unfavorable auspices, for Vermont on the preceding day had given Grant and Colfax an emphatic indorsement. ${ }^{1}$ This tended to dampen noticeably the ardor of the delegates ${ }^{2}$ at Albany. The chief pre-convention interest centered around the rival delegations and candidates from New York City and Brooklyn. Supervisor Tweed led the Tammany forces for Hoffman while John Morrissey led the opposition Brooklyn delegation for State Senator Henry C. Murphy.

Mr. Murphy was a politician of some note, having been mayor of Brooklyn, its corporation counsel, twice its representative in Congress and from $185^{6}$ to 1860 the United States Minister to the Hague. From 1860 he had sat in the New York senate, where he had advanced himself towards the governorship both in I866 and $1868 .^{3}$ Nevertheless, the backers of Mr. Murphy appeared to have made little progress against Hoffman prior to the convention. ${ }^{4}$ Their aim on the eve of the convention was to muster sufficient strength in order to force the nomination of a third man.

In spite of the opposition of John Morrissey, who had been one of the main factors in forcing the nomination of Hoffman two years before, the opinion seemed to prevail that Hoffman beyond question would be renominated. In

1 New York Herald, Sept. 2, I868.

'Among the more prominent delegates present were: Samuel J. Tilden, Sandford E. Church, Senator Murphy, John A. Green, H. A. Nelson, H. S. Randall, Judge Garvin, Peter B. Sweeny and Judge Connolly. Governor Seymour was not in attendance.

'New York Times, Sept. 2, 1868.

4 New York Sun, Sept. 2, I868; New York World, Sept. 2, I868. 
I 866 the country delegates in the main had united against Hoffman and his Tammany supporters because he was backed by Morrissey. Yet paradoxically in I868 Morrissey's opposition to Hoffman proved a recommendation for the latter. This may be explained by the fact that at this time Morrissey was more widely known up-State for his political trickery than were Tweed and his Tammany ring.

The aspirants for the lieutenant-governorship were A. P. Lanning, of Buffalo; A. C. Beach, of Watertown; General James McQuade, of Utica, the soldiers' candidate; and Smith Weed, of Clinton County, with chances in favor of Mr. Lanning. ${ }^{1} \quad$ The other offices incited no contest except for clerk of the Court of Appeals for which eight ${ }^{2}$ candidates appeared. Of these only Messrs. E. O. Perrin, W. B. Henderson and C. Ten Broeck were prominently mentioned. with Mr. Perrin in the lead.

Samuel J. Tilden, chairman of the State committee. called the convention to order in an optimistic address. A temporary organization was effected without dissent, $\mathrm{Mr}$. H. O. Cheesbro, of Ontario, taking the chair. The only contest for seats was between Isaac M. Marsh, of Richmond County, and Dr. James Harcourt. This was referred to a committee ${ }^{3}$ which later reported in favor of $\mathrm{Mr}$. Marsh. After arranging for committees on permanent organization and referring a motion on excise ${ }^{4}$ to its proper committee, the convention adjourned until $3: 30 \mathrm{P}$. M.

${ }^{1}$ New York World, Sept. 2, I868.

'George Becker, of Broome; Wm. H. Henderson, of Cattaraugus; Orrin W. Smith, of Delaware; E. O. Perrin, of Queens; Henry J. Glowack, of Genesee; Cornelius Ten Broeck, of Albany; James D. Little, of Putnam; Wm. Lounsberry, of Ulster.

3 Messrs. Beach, Tweed and Ross.

${ }^{4}$ New York Times, Sept. 3, I868. John Fox moved the following: "Resolved, That no Excise laws should be enacted except such as 
Upon reassembling for the afternoon session the committee on resolutions was appointed. One of the members of this committee from the eighth district was Grover Cleveland. Robert Earl, ${ }^{1}$ of Herkimer, headed the list of permanent officers. In his address when taking the cliair he echoed the principles of the Democratic National platform. A committee of two from each judicial district was appointed to report an electoral ticket. Under the guidance of Mr. Ten Eyck, of Seneca, the State committee was enlarged to thirty-three, one nember for each congressional district. In addition, on motion of Calvert Comstock, of Oneida, the president of the convention was empowered to appoint three members at large. ${ }^{2}$

Next in order of procedure was the nomination of a Governor. It appears that the nomination was conceded by practically all to John T. Hoffman, the Tweed candidate. Results verified this belief. After Hoffman had been nominated by George W. Miller, a letter was read to the convention by Mr. D. P. Barnard in which Senator Henry C. Murphy withdrew his name in the interest of harmony. ${ }^{3}$ Under the placid tone of this letter it would be hard for the uninitiated to suspect that a deep wound rankled. The supporters of Murphy felt deeply chagrined not only over the withdrawal of their leader but because certain leaders of the country districts hoped to make a combination against Tammany Hall. ${ }^{4}$ Mr. A. Oakey Hall seconded

are uniform in their operation throughout the whole State; and that the execution of such laws, and the collection of the taxes themselves thereunder, should only be through the medium of the local authorities of each county."

'Later of the Court of Appeals.

${ }^{2}$ New York World, Sept. 3, I868.

${ }^{3}$ New York World, Sept. 3, 1868.

- New York Tribune, Sept. 3, 1868. Among the leaders of this de- 
Hoffman's name, promising him 90,000 majority in the metropolis. Hoffman's nomination followed by acclamation, William Marcy Tweed leading the cheers. ${ }^{1}$

But Tweed's cup of joy was soon mingled with gall, for Tammany was bearded in its den. The nominations for lieutenant-governor were immediately called for. Levi $\mathrm{H}$. Brown, of Jefferson, nominated Allen C. Beach; Daniel Magone, Jr., nominated W. J. Averill, of St. Lawrence; and Albert P. Lanning, of Erie, was proposed by Mr. C. C. Torrance. Everything appeared regular until Judge Morris, district attorney of Kings, in seconding the nomination of Mr. Averill, turned upon Mr. Lanning and his Tammany supporters in a speech the vehemence of which had been seldom if ever approached in a Democratic convention. $^{2}$ Judge Morris warned the up-State delegates as to the true character of Tweed and company, declaring that in voting for Hoffman they voted for the same man to represent New York in the Senate. He pointed to the unfinished New York City court house and a thousand other schemes of robbery and plunder. Judge Morris sustained his attack with such vigor that by the time he had finished it was quite evident that the Tweed slate had been broken. ${ }^{3}$ No one raised a voice in defense of Tam-

feated movement were: Robert Chrystie, of the First Senatorial District; Secretary of State Nelson, of Dutchess; Senator Beach, of Greene; Erastus Corning, of Albany; John Morrissey, ex-Senator Blood, of Saratoga; W. S. Clark, of Schoharie; Jacob Hardenburgh, of U1ster and John A. Green, of Syracuse, who fared the worst of all as he was ignored at the convention and his place on the State Central Committee given to another.

1 New York Herald, Sept. 3, I868.

${ }^{2}$ New York Times, Sept. 3, I868; New York IVorld, Sept. 3, I868; New York Tribune, Sept. 3, 1868.

${ }^{3}$ New York Tribune, Sept. 3, I868. Syracuse Daily Journal, Sept. 4, I868. An extract from Judge Morris's speech: "The ring must 
many. The ring knew too well the wisdom of silence. Its eight million dollars profit on the county court house and other items would not bear cross-examination. Mr. Luddington, of Onondaga, finally attempted to pour oil on the troubled waters by urging the selection of his old schoolmate, Mr. Beach. The convention then proceeded to an informal ballot with the result as follows: A. P. Lanning, 47; A. C. Beach, 68; W. J. Averill, 9; S. T. Arnot, I. ${ }^{1}$ After the vote had been announced the nomination was made unanimous for Beach. The Murphy men considered this in the nature of a triumph and were in a measure appeased. ${ }^{2} \mathrm{Mr}$. Beach upon being called to the front thanked the convention. Further business appeared impossible because of sundry lacerated feelings, so the convention adjourned to the next morning.

The Kings County $v s$. Tammany incident of the convention was the result of a long-standing feud between the Democratic organizations on opposite sides of the East River. Due to divisions within the Kings County forces no effective opposition had been directed against Tammany for some time. ${ }^{8}$ In 1866 Henry C. Murphy had attempted to gain the gubernatorial nomination but failed through the opposition of General Slocum, who as a friend of President

have all, and all must bend to that ring. . . . They will demand to control the Federal patronage, should Horatio Seymour be elected, and he will be elected. Let them once secure that, and the unfinished court-house, and like jobs of theirs, will sink into insignificance when compared with what they will undertake in the same line.... When we came to Albany what did we find? We found every lobbyist, whether Democrat or Republican, employed working for them and their candidate." Much as he respected John T. Hoffman he felt that the combination referred to should not be permitted or tolerated.

1 New York Tribune, Sept. 3, 1868.

"New York Sun, Sept. 3, 1868.

${ }^{3}$ New York Herald, Sept. 4, 1868; New York Times, Sept. 4, I868; New York Commercial Advertiser, Sept. I, 1868. 
Johnson controlled considerable patronage. Two years had changed matters in Kings County, as Slocum, in return for Murphy's support on the bridge bill and other matters, was now his most earnest advocate. Tammany had also obligated itself to Murphy for his support on sundry measures, among them the police commissionership and the New York street-railways bills. Tammany forgot its many promises to Murphy. Hence in I868 we find the Kings County delegation solid for Murphy but failing to win its goal because of the treachery of Tweed.

The apparent futility of Murphy's candidacy was realized by certain of his supporters, who, as it afterward leaked out, had met on September ist and drawn up the letter of declination to which we have referred above. ${ }^{1}$ This action was forced, as it was known positively that twothirds of the delegates were for Hoffman. But had the Brooklyn delegation presented Murphy's name backed by the attack of Judge Morris the nomination would doubtless have gone either to Mr. Murphy or to a third man. Not only was Judge Morris prepared to support Mr. Murphy but several members of the Brooklyn delegation, which was conceded to be the ablest on the floor, were prepared with speeches to advocate Mr. Murphy and attack Tammany. With such men as Judge Barnard, Corporation Counsel McCue, General Slocum and Judge Morris, each able to enforce his views creditably as speaker and each fired with an animus, the public would have enjoyed such an exposure of Tammany's iniquities as would have startled even its enemies.

Be that as it may, the spectators who packed the galleries were rewarded with no open renewal of the quarrel when the convention reconvened at 10:45 the following 
morning. Chairman James B. Craig, of the committes on resolutions, submitted its report, which was adopted by acclamation. ${ }^{1}$ The platform was in the nature of a comment on the Democratic National platform. The preamble reaffirmed the National Democratic platform. Nine special clauses urged the immediate restoration of all States to their rights under the constitution, amnesty for all past political offenses, payment of all public obligations in strict accordance with their terms, equal taxation of every species of property including government bonds, one currency for all, the assertion of American nationality and the reform of abuse in administration especially in the South. The ninth article, after giving an expression of obligation to Andrew Johnson for his stand against a faithless party, and appreciation of the aid given by Chief Justice Chase against impeachment, strongly indorsed the national Democratic nominees. The platform took but two positions on matters of State policy, both of which were popular. These were demands for uniformity in the registration and excise laws throughout the State, and execution of the excise laws in all cases by local authorities. On the finance question the State platform was more outspoken than the national platform in declaring that when the bond stipulates gold, gold must be paid, but when it does not, lawful currency must be paid. In sharp contrast with this greenback doctrine one finds the Democratic State convention of Massachusetts adopting on September 2, I868, a resolution which stated "that gold and silver coin is the only constitutional legai tender." 2

${ }^{1}$ New York World, Sept. 4, I868.

2 lbid. 
The electoral ticket ${ }^{1}$ reported by James F. Pierce, of Kings, was ratified. Then followed nominations for the remainder of the State offices. For canal commissioner, Oliver Bascom, of Washington County, was preferred over Nathaniel Milliman, of Rensselaer, by a vote of 76 to $48 .^{2}$ David B. McNeil, of Cayuga, was nominated for inspector

1 The Democratic Electoral Ticket was as follows:

Electors-at-Large-Henry W. Slocum, of Kings; Delos Dewolf, of Oswego.

\begin{tabular}{|c|c|c|}
\hline 2nd & “ & Isaac Van Anden, of Kings. \\
\hline $3 \mathrm{rd}$ & “ & George L. Fox, of Kings. \\
\hline $4^{\text {th }}$ & “ & Joseph Dowling, of New York. \\
\hline 5 th & “ & Oswald Ottendorfer, of New York. \\
\hline $6 \mathrm{th}$ & “ & Emaneul B. Hart, of New York. \\
\hline 7 th & “ & Charles E. Loew, of New York. \\
\hline 8 th & “ & James M. Sweeny, of New York. \\
\hline gth & “ & Edward Jones, of New York. \\
\hline Ioth & “ & George B. Pentz, of Westchester. \\
\hline I Ith & “ & Egbert A. Clark, of Sullivan. \\
\hline I 2 th & “ & David Van Schaack, Columbia. \\
\hline I3th & " & Manly B. Mattice, Greene. \\
\hline I 4 th & “ & James Roy, Albany. \\
\hline I 5 th & “ & John B. Colby, Rensselaer. \\
\hline I6th & “ & Ruby H. Stone, of Clinton. \\
\hline I th & “ & Francis D. Flanders, Franklin. \\
\hline I8th & “ & Daniel D. Campbell, of Schenectady. \\
\hline Igth & “ & Simon B. Champion, of Delaware. \\
\hline 20 th & “ & Dewitt C. West, of Lewis. \\
\hline 2 Ist & “ & James McQuade, of Oneida. \\
\hline 22nd & “ & Matthew J. Schoecraft, of Madison. \\
\hline $23 \mathrm{rd}$ & “ & Oliver Porter, of Cortland. \\
\hline $24^{\text {th }}$ & “ & James McLean, of Seneca. \\
\hline 25 th & “ & William C. Dryer, of Ontario. \\
\hline 26 th & “ & Benjamin N. Loomis, of Broome. \\
\hline 27 th & “ & William R. Judson, of Chemung. \\
\hline 28 th & “ & William C. Rowley, of Monroe. \\
\hline 29 th & $"$ & James G. Shepard, of Genesee. \\
\hline $30 t h$ & “ & William G. Fargo, of Erie. \\
\hline 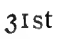 & “ & Timothy D. Cobb, of Chautauqua. \\
\hline
\end{tabular}

${ }^{2}$ New York Times, Sept. 4, I868. 
of State prisons, as were Colonel John M. Strong, of Syracuse, and John K. Burke, of Monroe. Mr. Burke, who was present as a delegate, declined to be a candidate and Colonel Strong's name was withdrawn before the complete vote had been taken, leaving Mr. McNeil the field. Although eight names ${ }^{1}$ were presented for clerk of the Court of Appeals, Mr. E. O. Perrin, of Queens, was unanimously nominated without taking a ballot. The State committee ${ }^{2}$ was then announced and after Calvin Frost, of Westchester, had presented a resolution in memory of Peter Cagger, the convention adjourned sine die.

Two papers of different faith, the Commercial Advertiser and the World, in commenting upon the Democratic candidates paid Senator Murphy a graceful tribute by acknowledging the excellence of his claims. ${ }^{3}$ To prove the ability, probity and popularity of Murphy's successful rival, the World published a sketch of Hoffman's career, ${ }^{4}$ and boldly challenged its opponents to compare platforms. Nevertheless, the World admitted that the Albany platform did not express the opinion of the entire Democracy, especially on money.

${ }^{1} C f$. footnote 2, p. 36I supra.

The Democratic State Committee was as follows:

Members-at-Large-Samuel J. Tilden, of New York; Samuel North, of Otsego; Joseph Warren, of Erie.

Ist district Peter B. Sweeny, Charles G. Cornell.

2nd " W. A. Fowler, Augustus Ide, of Orange.

3rd “ Wm. Cassidy, of Albany; Isaac McConihe, of Rensselaer.

4th “ Wm. J. Averill, of St. Lawrence; Isaiah Blood, of Saratoga.

5th “ George H. Sanford, John W. Barker.

6th " Stephen S. Arnot, N. Wilson Parker.

th “ E. P. Ross, C. C. B. Walker.

8th " Henry A. Richmond, James Jackson, Jr.

' New York Commercial Advertiser, Sept. 5, I868; New York World, Sept. 3, I 868.

"Ibid. 
The Sun contributed an editorial on the Democratic State convention which was notable for its rollicking good humor. It considered the convention " a miracle of harmony " 1 in which the solid masses of the phlegmatic Teutons " had worsted the fiery, gallant sons of Erin. As for the rival candidates for Governor, they were well matched. both being young men, rich and exceedingly good looking. Then followed a minute comparison of the candidates as to their looks. ${ }^{3}$ This editorial was intended to convey the moral that matters of State interest or names on the State ticket would occupy but a comparatively small place in the public mind throughout the canvass. The Hcrald deigned to give no space editorially to the Democratic candidates or platform. ${ }^{4}$ Greeley merely pointed out the "restlessness and discontent of a powerful wing of the party under the imperious yoke of Tammany". which was made planly visible.

'New York Sun. Sept. 3. 1868

2 New York Herald. Sept. 3, 1868 . Contemporaneous with the Democratic State Convention the German Democrats met in convention at Albany under the call of Oswald Ottendorfer. Chairman of the German State Central Committee. This convention supported Hoffman and urged a change in the Excise Laws.

"New York Sun, Sept. 3, 1868. "Both are exceedingly good-looking. though not of the same style of beauty. Mr. Griswold is a blond, with blue eyes, light hair. and mutton-chop whiskers. His movements are graceful, his manners elegant. Mr. Hoffman is a brunette, slender, tall, stately, with fine black eyes tinged with melancholy. His hair is jet black, his brow pale and thoughtful like Hamlet's. his features finely cliseled. his chin smooth and shapely, his mouth intellectual and kindly. his moustache black and inpressive, like that of a Spanish grandee or a first class German metaphysician. In point of personal attractions, it would be difficult to determine which of the two candidates ought to have the palm. If the question were left to the ladies, they wnuld find themselves puzzled beyond any precedent in history."

- New York Herald, Sept. 2-5, 1868.

- New York Tribune, Sept. 4, I868. 
Consistent with its estimate in I866, the Times considered the Democratic choice for Governor creditable ${ }^{1}$ as well as prudent." Personally unobjectionable, cultured, experienced in administration, Mr. Hoffman was the strongest man the Democracy could present. ${ }^{3}$ With the nominee for lieutenant-governor, Mr. Beach, the Times was not so fair, describing him as "a gawkey, good-natured personage, great of girth and tall of stature, who timidly vented some incoherent vagaries." 4 The platform received no attention from the Times. As with the up-State editorial notice of the Republican State convention so it was with the Democratic State convention; practically no attention was given to its proceedings or results. Where an up-State opposition paper gave it any space, attention was directed to Judge Morris's attack on Lanning and Tammany, ${ }^{5}$ while the district party organs gave but perfunctory comments. ${ }^{6}$

${ }^{1}$ New York Times, Sept. 4, I868.

Ibid., Sept. 3, 1868.

Ibid.

- Ibid., Sept. 4, 1868.

- Syracuse Daily Journal, Sept. 4, 1868.

- Albany Argus, Sept. 3, 4, I868; Buffalo Daily Courier, Sept. 2-4, 1868. 


\section{CHAPTER XIII}

\section{The Presidential. Campaign of i 868}

Although the issues pending upon the outcome of the Presidential election of 1868 were doubtless not of such vital importance to the life of the nation as those involved in the campaign of I860, still we may safely state that with the exception of the latter campaign, none has been more fraught with significance to the political and economic future of the United States than the former.' The issue before the country was, should the Radicals be permitted to finish their Reconstruction of the South, or should an administration be returned which would undo the work of the Radical Congress with the attendant results.

After the major conventions the campaign did not open with much éclat, as most of the leaders took a respite at the resorts. The newspapers in July indulged themselves chiefly in prophecy according to their different faiths. One week after the Democratic convention the Times claimed that already the Democrats were having difficulty to keep up enthusiasm for Seymour. ${ }^{2}$ The World was sure that nothing could save the Radicals from defeat in November. ${ }^{3}$ The Herald thought that New York would go Republican because Grant and Griswold were both liberal on the drink

1 Fite in his introduction omits mention of the campaign of 1868 , when comparing those of 1840,1856 , 1864 with that of 1860 . Fite, The Presidential Campaign of 1860 , Introd., ix.

- New York Times, July 17, 1868.

- New York World, July 29, I868. 
question.' But the Sun made the only prediction which fully came to pass, when it argued that the Democrats would carry New York in spite of everything while the nation went Republican." Nothing had occurred during the year to alienate the liquor element in and around New York City, hence the Sun maintained that the Democratic majority in the State would be practically the same as the previous year.

The Republican organs based their clains for a Republican victory on the popularity of Grant as contrasted with the war record of Seymour. The Independent predicted a Republican victory on the ground that the Republican platform, although not advanced enough to please the Radicals. was adapted to the ideas of that wing of the Democracy which desired the nomination of Chase. while the Democratic platform was too outrageous for a large portion of the Democracy."

Incidental to the campaign auguries, the usual display of brotherly affection on the part of certain papers was made manifest. The Commercial Advertiser ${ }^{*}$ warned Republicans against the support of Grant by the Tribune, while the 1 orld ${ }^{5}$ took the latter as its special foeman. Needless to say the Tribune saw to its own laurels. The Independent read the World out of the leadership of the Democratic party becatuse it was not snfficiently audacions. ${ }^{6}$

${ }^{1}$ New York Herald, July 21, 1868.

S New York Sun, July 14, 1868. The Sun cited the following majorities as proof of its claim:

In 1860 New York gave Lincoln 50,000 majority. In 1862 New York gave Democrats II,000 majority. In 1866 New York gave Reputhlicans 14,000 majority. In 1867 . New York gave Democrats 48,000 majority.

- The Independent, July 16, 1868.

4 New York Commercial Adiertiser. July $17,1868$.

5 New York World, Ang. 8, 10, 24, 26, 29, 30, 1868.

"The Indipendent. Aug. 6. 1868 . 
The keynote of the Democratic campaign was given in a letter from Samuel I. Tilden to the Seymour and Blair ratification meeting at Washington. The issues as Tilden saw them were two, namely, opposition to negro supremacy, and opposition to the monstrous fiscal extravagance of the Republican party. ${ }^{1} \quad$ These resembled the issues as the $W$ orld saw them, $i$. $e$., reduction of the army and navy, and abolishment of the Freedman's Bureau. ${ }^{2}$ The Republicans were thus forced to meet the issue.

In August a campaign book, compiled by special commissioner of the revenue David A. Wells, was circulated in which the expenses of the administration since the War were enumerated. ${ }^{3}$ These figures were hailed with delight by the Democrats, who could now use authentic Republican figures to show just how expensive and extravagant the Republican administration had been. "At present nobody can advocate economy without thrusting a sworl into the vitals of the Republican policy." said Tilden."

On the other hand, while the Democrats were leading their forces against the Republican extravagance, Vallandigham and other Democratic orators of the West pretended to see in Seymour's utterances an interpretation of the Democratic platform acceptable to Westerners on the greenback question. namely, the payment of that portion of the national debt known as five-twenties in greenbacks.

${ }^{1}$ New York World, July 21, I868. John Bigelow, The Life of Samuel J. Tilden, vol. i, pp. 215-17.

¿ New York World, July 24, I868. New York World, Oct. I3, I868. The World later defined the real financial issue between the two parties thus: "Whether we shall stop the extravagance which has raised and spent enough money since the war to have paid off all of the 5-20 bonds."

'Ibid., Aug. I, I868. The Army and Navy expenses since 1865 to the publishing of this book were $\$ 1,050,237.319$.

4 New York World, Oct. 2, I868.

"Ser New York Herald, Aug. 16. I868. 
A certain support on this point was given to the Democrats by the Evening Post which, although it doubted the constitutionality of the legal tender act, felt reassured that business would be safe in the event of any change in currency. ${ }^{1}$

As money proved to be the battle center of the campaign, so in the matter of personal politics did money-making, at the government's expense, prove to be a vulnerable spot for attack in the case of John A. Griswold. The World early discovered a mare's nest in the career of Griswold, whom it called an "imposter" and a "confidence candidate ". The facts as set forth by the World show that John A. Griswold and his partner John F. IVinslow went as sureties on Ericsson's contract." This contract with the government to build the Monitor was entered into July 2, I862. Griswold and Winslow furnishing the iron for the vessel. In December, I863. Griswold took his seat in Congress as a Democrat. He voted against Colfax for speaker, Mr. Henry G. Stebbins, of New York City, being his choice. Later Griswold voted for his own petition for relief in connection with a heavy loss ${ }^{4}$ which threatened two others and himself on the contract. These facts, according to the Democratic journals and orators, furnished prima

\footnotetext{
1 New York Ez'ening Post, Sept. 1, I868.
}

- New York World, Aug. 27, 1868. New York World, June I, 6, 1868. The IVorld was no less severe in its attacks on Grant. In connection with his speech of acceptance it spoke of him as a "puppet" and a "weather cock." Grant's statement that he would have no policy of his own "to interfere against the will of the people," was a "self-pronounced satire on General Grant's intellect and moral independence." Contrast with this, the statement of the Sun on Grant's acceptance, "It is short, sharp and decisive." New York Sun, June 2, 1868.

3 The inventor of the Monitor.

- New York World. Aug. 12, 1868. 
facie proof of Griswold's unsuitability for the office of Governor. The Argus ${ }^{1}$ was an able second to the World in hurling this charge against Griswold. The Argus claimed that Griswold had made $\$ 100,000$ for himself and partner on the Monitor. The Republican journals, especially the Troy Times, ${ }^{2}$ defended Griswold's action by showing the tremendous advantage the victory of the Monitor over the Merrimac gave to the North at a very critical period. Griswold's act in putting up the money to build the Monitor was lauded as the highest example of patriotism. The Times supported Griswold, backing the assertion of the Troy Times that the Monitor had been built at the personal expense of Griswold and his associates and was owned by them at the time of the Merrimac encounter." These statements and those of Griswold's supporters ${ }^{4}$ to the same effect were later branded as false by Secretary of the Navy Gideon Welles. "The work of building the Monitor," said IVelles,

was paid for as it progressed. Six payments were made between the middle of November and $3^{\text {d }}$ of March, before the vessel was completed and delivered. The last and final payment, save the reservation which by contract was to be retained until after a satisfactory test, was marle before she left New York on her trial trip."

1lthough Welles makes it clear" that he was up in arms

1 Albany Argus, Aug. 4, I868.

${ }^{2}$ See Troy Times, Aug. 15, 1868. See New York Sun, Aug. I8, 1868

New York Times, Aug. 17, 1868.

-Welles singled out General Benjamin F. Butler especially as one who had made false statements on the Hoor of the House relative to Griswold.

"The Diary of Gideon IVelles, vol. iii. p. 413, also see vol. i, pp $213-215$.

"Ibid., vol. iii, pp. 412-414. "John A. Griswold, a wealthy iron- 
against the attempts made by Griswold's friends to slander the navy department, still his authoritative statements as Secretary of the Navy wonld seem to deny any validity for Griswold's claims.

Hoffman made his opening campaign speech at Buffalo on September 8th in which he proclained that the Democrats had but one object, i. e., the public good. He praised the conduct of the War and assailed the Radicals for not having lifted the country out of financial anarchy three years later. ${ }^{1}$ The World ably seconded Hoffman, claiming that under Seymour the only danger from anarchy would be the failure of the Republicans to submit to the party in power. ${ }^{2}$

The Times devoted its strength to a financial rebuttal. No one but the Democrats were to blame for a war the price of which was $\$ 4.07$ I,030,060. ${ }^{3}$ The plausible equal tax on all property was regarded by the Times as the weakest plank in the Democratic platform because a tax on government bonds could not be made in view of recent Supreme Court decisions. The Tribune and the Eiening Post directed their attack against Hoffman's relationship to

master and Nember of Congress, has been nominated for Governor of New York by the Radicals, and there has been. and is, a persistent attempt to give him false credit in regard to the Monitor, and this by systematic and deliberate falsehood and injustice to the Department.--Yet the Hon. Mr. Griswold, knowing the facts, himself a party, sat quietly in his seat and took to himself this false credit without one word of explanation or justice to the Nary Department. His biographers have, I am persuaded by his connivance, not only made the same statement as Butler, hut have gone farther and tried to ignore the Navy Department. or have slandered and belied it by declaring the Secretary was opposerl, or only gave a negative support, io Mr. Griswold and his associates."

'New York Sun, Sept. 9, I868.

2 New York World. Sept. 7, I868.

${ }^{3}$ New York Times, Sept. 2, I868. 
Tammany Hall. Hoffnan was but the "pliant tool " and "gypsy candidate" of Peter B. Sweeny and William M. Tweed. (ireeley stated, we know now rightly, that with Hoffman in office it virtually meant Sweeny ' for Governor with 'Tweed as Governor's assistant."

The Miaine elections ${ }^{3}$ gave the first definite indication of the results to be expected in November. The Republican Governor, Chamberlain, was re-elected over Pillsbury, the Democratic candidate, by a 20,000 majority, an increase of I0,000. In New York the Maine results were variously received. The Times was complacent. It the Cooper Lnion monster mass meeting held on the night of September I fth. Henry J. Raymond argued that all the country neederl was four years of quiet. ${ }^{4}$ In his arguments he was seconded by General Kilpatrick and Charles S. Spencer. But Greeley apparently was not deceived by the situation in Maine. for he warned the New York State Republicans to force the fighting, as the situation in the State while hopeful was far from safe." The World assured all that the Republicans by their frenzy of joy over Maine only showed their fear of defeat in November. ${ }^{6}$ Such sureness was not displayed by the Sun, although it credited the Naine election to the folly of the Democrats in their choice of leaders. ${ }^{\top}$

The Herald, also, read into the Maine election Repub-

' Sweeny furnished the brains for the Tweed Ring.

2New York Tribune, Sept. 5, 1868; New York Evening Post. Sept. 3. 29,1868 .

The September elections in Vermont, Maine, Connecticut, Colorado. and New Mexico all returned Republican majorities.

- New York Times, Sept. 15. 1868.

- New York Tribune, Sept. 16, 1868.

${ }^{6}$ New York IVorld, Sept. I7, 1868.

${ }^{7}$ New York Sun, Sept. 15, 1868. 
lican victory both nationally and in the State. Its argument in connection with the State is interesting. The Herald maintained that in 1867 the Germans and Irish of the State had rebelled against the license law. Also the friends of Seward and Weed in the custom houses, the post offices, the internal revenue bureau and in every school district of the State had voted against the Radical ticket. The Grant men had either voted with the Democrats or remained away from the polls. In I 868 , the Herald pointed out that all was different. The Democrats during the past winter with a majority in one branch of the legislature and possessing the power to force from the Governor a valuable modification of the metropolitan excise law removing all offensive measures, betrayed their friends and obstructed any alteration of the law in order that they might retain it as an argument for another campaign "Liquor men," reassured the Herald, " will not be deceived another time, besides, Griswold is for them." " Nationally the Herald believed Grant would be elected because of the Democrats' stupidity in adhering to their platform of i $864 .^{2}$ Or as the Independent put it, a considerable body of voters who were not satisfied with Republican leaders and ideals, still would vote for Grant because of the war talk of the Democrats and Blair, ${ }^{3}$ the Tammany convention methods and the financial policy of the Democrats. ${ }^{4}$

The Republicans followed the advice of Greeley, redoubling their activities in the mid-campaign. John A. Griswold was very active. The tenor of his arguments was largely national. He believed that the people should

1 New York Herald, Sept. I7, 1869.

- New York Herald, Oct. 2, 1868.

${ }^{3}$ The Independent, Sept. 24, 1868.

'Ibid., Oct. 15, 1868. 
help the victors maintain peace. ${ }^{1}$ He did not believe that the late rebel States and their rebellious citizens should be admitted at once. Further, a large part of his public addresses were directed toward the questions of national finances, showing that the Radicals had reduced the war debt one-quarter and hach relieved the country of taxation to the amount of $\$ 167,000,000$ per annum."

The Republican State ratification meeting was held at Cooper Union on September 22d. John A. Griswold, General J. C. Fremont, General John B. McKean and Martin I. Townsend addressed the meeting. The speeches were all directed against the financial measures of the Democrats. Martin I. Townsend believed in pushing the debt and tax questions until they drew blood." Five nights prior to this meeting a similar gathering had been held at Cooper Union in commemoration of the Battle of Antietam, at which 8.000 persons had heard the enthusiastic addresses of Generals Pleasanton, Sickles, Kilpatrick, Colonels G. C. Sharpe, and Deming, and Senator John Sherman. All the powers of oratory and argument were employed to keep the soldiers of the State from joining the Democratic ranks. Senator Sherman assured all that Ohio and Indiana would follow Vermont and Maine. ${ }^{*}$ The position of Senator Sherman on the five-twenty bonds of the United States, namely, that they could be paid off in greenbacks, "gave the Democrats a capital argument in which they claimed that he had surrendered and spiked the gums of his party. ${ }^{6}$

${ }^{1}$ At Poughkeepsie. New York Tribune, Sept. I7, I868.

3 New York Tribune, Sept. 18, 1868.

Ibid., Sept. 23, 1868.

- New York Tribune, Sept. I8, 1868.

- Cf. ibid., Aug. 25, 1868. Doubtless a statement made by Sherman for campaign purposes.

- New York World, Aug. 26-28, 1868. 
The Republicans made special appeals also to the Irish and the German elements in New York City at Cooper Union on September 3 oth and October 7 th respectively, at which meetings the rights of citizens to the customs of their fatherland were upheld. Yet it was pointed out that regard must be given to the rights and even the prejudices of others. ${ }^{1}$

While the campaign was thus in progress in New York State, elections were held in Pennsylvania. Indiana, Nebraska and Ohio. The verdict in these States was unmistakably for Grant. ${ }^{2}$ The substantial predictions of Henry $W$. Beecher, uttered four days prior to the October elections, ${ }^{3}$ came true. Greeley could not see how, any way we might figure, Seymour could be elected in view of the October elections. ${ }^{4}$ The $W$ orld pretended to consider the results as indicative of a fine showing for the Democrats, considering that they had been proclaimed dead by their opponents two years before. Said the World: "If the military prestige of General Grant had been out of the scale, we should have succeeded; or that remaining, if the perversions of General Blair's position had been out of the scale. we should have succeeded." "Thurlow Weed was especially severe in his condemnation of Blair, whom he classed with Wade Hampton, Wise, Vance. Forrest and Hill. "These

${ }^{1}$ New York Tribune, Oct. I, 8, 1868.

'Ibid., Oct. 14, 1868.

' New York Times, Oct. Io, I868. At Brooklyn Academy of Music. Beecher, also, wrote a letter at this time on the condition of the country in which he urged the need of hetter administration. The World gave special attention to this letter and replied that the claim was true but questioned whether Grant had the necessary experience or qualities to give the administration demanded. New York World. Oct. I2, I868; New York Evening Post, Oct. IO, I868.

- New York Tribune, Oct. 14, I868.

' New York World, Oct. 15, I868. 
men have determined to make I868 in the likeness of 1860. Cover up their purposes as they may, the people penetrate the disguise and detect the sham." ${ }^{2}$ The Herald and the Sun both acknowledged the certainty of Grant's election in November." But the Sun maintained that the October results would not alter the hold of the Democrats upon New York State.

One immediate result of the Democratic defeat in the October elections was a demand on the part of the World. backed by the National Intelligencer, that a change be made in the Democratic ticket. On October I 7 th the World openly blamed Blair for the defeat " and two days later it admitted that the Democratic situation was very doubtful. Calling on Seymour, as the only man who could do so, it asked him to lead them out of the wilderness. ${ }^{4}$ But the World's invitation to Blair was of a vastly different import. "Governor Seymour can now aid us nuch but General Blair can aid us far more, in a different way, by a chivalric action superior to all eloquence." The cry for Blair's withdrawal was taken up in many quarters. Blair's chief defender proved to be Horace Greeley, who facetiously spoke of the Democratic ticket as "a den'd moist unpleasant body "." Blair publicly announced at St. Louis that he was rearly to withdraw if his friends thought best. ${ }^{\text {" }}$

Washington was thrown into a futter. George Pendleton and Washington McLean, ${ }^{\top}$ of Cincinnati, hurried to

' New York Commercial Advertiser, Oct. 14, I868.

'New York Herald, Oct. 15. 16. 1868; New York Sun. Oct. 1, 15. 1868 .

New York World, Oct. 17, 1868.

'Ibid., Oct. 19, 1868.

'New York Tribune. Oct. 17, 1868.

- New York Times. Oct. 18, 1868.

'McLean controlled the Cincinnati Gazette and the Cincinnati Enquirer 
the Capital. Chase again loomed up as a candidate. President Johnson was spoken of for Seymour's place with Generals Ewing and Hancock, or Governor English, of Connecticut, for Blair's place. Hancock, however, refused to consider second place and Seymour announced that any change in the ticket must necessarily include him. ${ }^{1}$ The Evening Post suggested that the Democrats drop Seymour and Blair and substitute Grant and Colfax. ${ }^{2}$ As no one was found ready to stand in the breach and take up the burden of unpopularity which Seymour and Blair were too weak to lift," and as, in New York, Samuel J. Tilden, Iugust Belmont and Augustus Schell held firm for the ticket, it weathered the attack of the World.

For its display of the white feather the World was forced to stand scathing attacks from the Democratic press throughout the country. ${ }^{4}$ The Argus, ever a staunch Democrat, was moved to express its disgust over the situation.

Governor Seymour cannot cut loose from General Blair. He cannot arbitrarily relinquish a candidacy he dicl not seek, and which was forced upon him as a duty. And who would take the vacated post? Who would covet the dubious honor? . . . The game of corruption and frand cannot twice be played. The money raised to stimulate, and to bribe voters, has been spent. ${ }^{5}$

It was thought by many that Washington McLean, who controlled the Cincinnati Gazette and the Cincinnati Enquirer, inspired the World to demand the change in the

${ }^{1}$ New York IVorld, Oct. 19, 1868.

- New York Evening Post, Oct. 16, I868.

${ }^{3}$ See New York Commercial Advertiser, Oct. I6, 1868.

4 Newark (N. J.) Democrat, Oct. 19, I868; Rochester Express, Oct. 18, I868; Hartford Times, Oct. 19, I868; Boston Post, Oct. 18, I868; The Independent, Oct. 22, 1868.

s Albany Argus, Oct. I8, I 868. 
ticket, as it was he who at once revived the clamor for Chase. ${ }^{1}$ The Rochester Daily Democrat believed, nevertheless, that the World, the National Intelligencer and other Democratic papers wanted Seymour and Blair to resign because the South was dropping away. ${ }^{2}$

The Republicans continued their attack on Blair for his insistence that Grant once in the White House would never leave it alive. ${ }^{3}$ Seymour was ridiculed for the implied basing of his candidacy upon two grounds, namely, that Reconstruction was a failure therefore he should be elected, and that he would be unable to do anything if he were elected President therefore he should be electer. ${ }^{+}$

The War Democrats who were acting with the Republicans held the last great mass meeting of the Republican campaign at Cooper Lnion on October 2 Ist. It is illuminating to note that the list of rice-presidents for the meeting contained names of such prominence in the affairs of State as William F. Havemeyer, William B. Astor, Alexander T. Stewart, Aaron Vanderpoel, John Jacob Astor, Jacob A. Westervelt, Henry G. Stebbins, C. V. S. Roosevelt. James J. Roosevelt, W. H. Webb. John C. Green, Robert L. Stuart. Edmund H. Schermerhorn. Stephen Philbin. Henry Clews, Peter Cooper. Cornelius Vanderbilt, Samuel Sloan. and William J. McAlpine." The chief speaker was Judge Edwards Pierrepont who attacked the Democrats on their War record, revolutionary utterances and prevalence of fraud. Pierrepont was he who had knifed General Dix two years previously and had brought

1 New York Tribune, Oct. 20, I868.

2 Rochester Daily Democrat, Oct. 21, I868.

- New York Times, Oct. 20, I868.

4 New York Tribune, Oct. 27, I868; New York Times, Oct. 30, 1868.

- New York Tribune, Oct. 22, 1868. 
Hoffman forward.' When Pierrepont publicly announced himself for Cirant and Griswold, his letter acted as a bomb shell in the Denlocratic camp."

Blair invaded the East to defend himself against the charge of being a revolutionist. It Tammany Hall on October 27 th he cast the charge back upon his political enemies ${ }^{3}$ of the Republican party. The Herald vigorously defended Blair, arguing that once in office he would naturally become conservative. ${ }^{4}$ The $W$ orld found it difficult to hicke Blair under a bushel. It openly coumseled that everything in the State and the nation depended upon occupying public attention with Seynour." When Blair came East. Seymour entered the West in the hope that a change of location might induce a reaction for the better."

According to the World. Hoffman was strong in the State but it deemed the electoral ticket of greater importance. From the middle of October it devoted its entire editorial strength to carrying New York. It made further assaults upon Horace Greeley who had been directing a large share of his attention to disclosing election frauds, ${ }^{7}$ particularly those by Judge George G. Barnard, ${ }^{8}$ who made such a unique record for rapid naturalization.

The Democratic State committee's address was issued by August Belmont on October 2Ist. in which the extravagance of the Republicans was denounced. lugust Belmont then retired to Europe where he could take the Demo-

1 Vide supra, pp. I05, 106.

"Syracuse Daily Courier and Union, Oct. I4. 1868; New York World, Oct. 13, I868.

${ }^{3}$ New York Herald, Oct. 28, 1868.4 'Ibid., Oct. 30, 1868 .

${ }^{5}$ New York World. Oct. 2I, I868.

- New York Herald, Oct. 28, i 868.

New York Tribune, Sept. 15; Oct. 15, 16, 1868.

' Ibid., Oct. 23, 26, 1868 . 
cratic defeat in safety. ${ }^{1}$ On October $27^{\text {th }}$ the Republican State committee issued its address to the people, in which it raked the Democracy of the nation fore and aft for attempting to excite the war passions again, and the Democracy of the State for its political jobbery in illegal naturalization at $\$ 2.00$ per person. ${ }^{2}$ The Commercial Advertiser added its voice against the naturalization frauds and urged the men of New York City to overthrow fraud and vote for Griswold who had saved the commerce of New York City by building the Monitor. ${ }^{3}$ Jist before election a proclamation was issued by Mayor Hoffman, in which the Mayor warned all Democrats against the Republicans as dangerous men seeking to discredit the Democracy and turn attention from their own guilt by unscrupulously gross and unfounded charges against those high in authority. The proclamation also flayed the federal grand jury then in session for bringing in indictments. Greeley's reply to Hoffman's proclamation was characteristic.

The Republicans of this city are, as they have always been, a minority. They would not be if the city were not governed so as to make her vast array of thieves, emigrant-swindlers, sailorpluckers, blacklegs, pocketbook-choppers, baggage-smashers and brothel-keepers a unit against them . . . There is no vice, there is no crime, no outlook of lumman lepravity, that is not made to bring grist to the Democratic mill. ... Of the infamous "Ring" of swindlers who misrule and plunder us, we ask only . . that they do not rob us outright of our votes by stuffing the ballot-boxes with ballots cast by "repeaters" and unnaturalized or fraudulently-naturalized aliens. ${ }^{4}$

${ }^{1}$ New York Sun, Oct. 2J, I868.

'New York Tribune, Oct. 27, 1869 .

- New York Commercial Advertiser. Oct. 20, 1868.

'New York Tribune, Nov. 2, I868. 
In striking contrast with the lethargy of the up-State leaders and journals in connection with the State conventions of both parties we find a refreshing activity over the national and State campaigns. The Republicans held three monster mass meetings in Syracuse on September 8th. October 2nd, and October 28th. The first meeting was addressed by Carl Schurz in German: ${ }^{1}$ at the second. John Griswold and Chauncey Depew spoke. Griswold devoted his attention to proving that the financial issue had been extravagantly overdrawn by the Democrats. ${ }^{2}$ Depew contrasted the Chicago and New York platforms. The third meeting was held to dran the Irish wote to the Republicans. $^{3}$ The Irish and Gernan rote up-State was courted by the Republicans on the ground that the Democratic party had made no emphatic assertion or attempt to enforce the claims of adopted American citizens. while they had seen their clainus vindicated by a Republican Congress. ${ }^{4}$

Roscoe Conkling returned to Utica from the Rocky Mountains about October ist and, after an address at Cooper Union one week later, devoted his splendid energies to defeating his brother-in-law. Horatio Seymour. in Oneida and adjoining counties. While canvassing one day with his friend Benjamin Allen, Conkling met and shook hands with a swarthy Irishman. an employee of Allen's. Allen said. "Senator. Black Paddy, as we call him, has turned Democrat." "How so?" queried Mr. Conkling. With the ready wit of his nation "Black Parly" " replied. "Shure, sir, oi'm payin' ye a compliment in votin" for yer brother-in-law." "

1 Syracuse Daily Standard. Sept. 9, 1868.

" lbid., Oct. 3, I868.

- Syracuse Daily Journal, Oct. 29, 1868.

'Syracuse Daily Standard, Oct. 29. I868.

' Alfred R. Conkling, Life and Letters of Roscoe Conkling. pp. 312-13. 
Syracuse was likewise the center of the Democratic upState activities. Their most important meeting was held on September I $3^{\text {th }}$ at which John Hoffman and Richard O'Gorman spoke. Hoffman, as at Buffalo and Rochester. devoted his attention to the national debt and the unnecessary expenses to which the Republicans had put the government. The up-State Democratic papers gave almost their entire editorial strength to attacking the Republicans upon these points. ${ }^{1}$ The aim of the Democrats, as interpreted by the Syracuse Daily Journal, was to push the matters of debt and taxation upon the public attention, thus to divert the public mind from the question of Reconstruction and the possibility of another civil war. ${ }^{2}$ The Syracuse Daily Journal, also, attempted to show how a Democratic victory would menace free labor. stating that no help would be hired in the South unless the laborer promised to vote for Seymour and Blair, and that those already in service had been warned that their failure to vote for the Democratic nominees would mean the loss of their jobs. ${ }^{3}$

The Republican stronghold in the northern part of the State was the scene of a vigorous campaign. But the Democratic opposition in the northern counties melted after the announcement of the October elections. ${ }^{*}$ Yet the Syracuse Daily Conrier and Union had sufficient faith in its convictions to hotly claim States conceded to be Radical." "Cowards lose the fight ere it is half begun-brave men never." was the slogan of the Daily' Courier and I'nion.

${ }^{1}$ Syracuse Daily Courier and Union, Sept. 14, Oct. 1, 7, I868. Buffalo Daily Courier, Aug. 17. Sept. 11, Oct. 27, I868.

- Syracuse Daily Journal, Sept. I4, 1868.

- Syracuse Daily Journal, Sept. 14, 1868.

- Ogdensburg Daily Journal, Oct. 15, 1868.

${ }^{5}$ Syracuse Daily Courier and Union, Oct. 16. 1,868. 
The Radical up-State press in general used the September and October elections as a moral for the campaign. The Albany Eicening Journal summed up the issues of the presidential campaign as follows: I. "Reconstruction is substantially accomplished. A re you going to approve of it? 2 . It cost money to put down the Democratic rebellion. Are you going to join the Democrats in repudiating the just war debts?" I It further indicted Seymour on three counts, namely, inciting to riot, yielding to rioters their demands on the government at the peril of the nation, and threatening the President of the United States with the violence of the people, if he proceeded in efforts vitally necessary to the salvation of the Union. ${ }^{2}$ Throughout the campaign the Evening Joumal especially assailed Seymour for his WVar record and urged Griswold's election because the State was in need of a sound financial system. ${ }^{3}$ But by October 2 Ist the Evening Iournal apparently gave up hope of electing Griswold. ${ }^{4}$

Roberts gave the Utica Morning Herald a very conservative tone, constantly warning the Radicals not to become over confident." The questions of national import received chief attention, especially the idea of State sovereignty. Roberts believed in the doctrine of States rights as defined by the constitution, but not in State sovereignty. ${ }^{8}$ The only matter of State interest to attract continual attention from the Morning Herald was the lack of economy under the "Ring " in New York City. ' The Rochester Daily Domo-

' Albany Evening Journal, July 17, I868.

2 Albany Ezening Journal, July 17 , I 868.

I Ibid., Sept. 9, 24, 25, Oct. 10, IT, 12, 1868.

4 Ibid., Oct. 21, 1868.

5Utica Morning Herald. Sept. 3, 4, 1868.

- Ibid., Sept. 9, т868.

'Ibid., Sept. 25, 30. Oct. 6, 20, 21, 22, 23, 1868. 
crat, also, scored the "Ring" in New York City for resorting to naturalization frauds. ${ }^{1}$ The Daily Democrat in the early campaign developed a special fight of its own over Lewis Selye, the Radical candidate for Congress from Monroe, whom it accused of supporting the Democratic cause with money. Although supported by the Rochester Union Advertiser ${ }^{2}$ and a host of friends Selye resigned. The Daily Democrat, after investigation of the facts, admitted that it had said things which it wished were unsaid. ${ }^{3}$

As suggested the Rochester Daily Democrat and the Rochester Union Advertiser enlivened their local campaign by a merry fight, as did the Express and the Daily Courier in Buffalo. The Buffalo Express, aside from giving attention to the national campaign, devoted its local interests to advocating improvements for the Erie canal and censuring Seymour for his opposition to its improvement and enlargement." The Buffalo Daily Courier, advancing the usual arguments against the debt and Republican extravagance, ${ }^{5}$ reviewed Griswold's War record as a government contractor, ${ }^{8}$ and sneered at Grant's statesmanship judged by his short speeches. Further, it condoned the naturalization frauds in New York City. ${ }^{7}$ But like its local opponent the matter of water ways and their effect on Buffalo held its chief local attention. It urged the voters of Erie County to remember that Roscoe Conkling voted for the Niagara ship canal on May I, I866, and received the United States Senatorship for it. Griswold, also, voted

${ }^{1}$ Rochester Daily Democrat, Oct. 6, Nov. 2, 1868.

'Democratic.

'Rochester Daily Democrat, Sept. 14, I868.

4 Puffalo Express, Oct. 17, Nov. 2, 1868.

' Buffalo Daily Courier. Aug. I7, Sept. II, 1868.

- Ibid., July 22, 1868.

' Buffalo Daily Courier, Sept. 7. 1868. 
for it and was to be made Governor. This ship canal it was believed would ruin the trade of the Erie and lience the shipping of Butfialo.

The last event of importance in the up-State campaign was the appearance of William H. Seward at his old home in Auburn. There on October 3 ist he nade an address to his neighbors which caught the attention of every one in both parties. Seward had remained silent throughout the campaign. a fact which was interpreted to mean disapproval of his party's candidates. The old leader pleaded the burden of his duties as Secretary of State and inadequate strength to undertake an active part in the campaign. Seward stated that in his belief the late rebel States could not be safely intrusted to any men but those " drawn from and representing that class of citizens who maintained the government in the prosecution of the Civil War and in the abolition of slavery." " He reviewed the history of the leading political parties, and commended Johnson, but he gave slight attention to the candidates before the country. Seward's hopeful generalities, in short, manifested little of his old mental vigor. "Seward's speech." said Andrew D. White." was an unfortunate ending to a great career." :

On the eve and the day of election the Republican journals were filled with presentment of the gigantic frauds which were to be perpetrated. The county clerk of Orange County was under arrest and the county juclge was threatened with arrest over naturalization frauds. In New York County the gross frauds which we now know were carried on, were violently denounced by the Republican organs to no avail. In Brooklyn a severe quarrel broke out between

'Buffalo Daily Courier Oct. 27, 28, 29, 1868.

- Seward's Works, vol. v, pp. 540-558.

3 Autobiography of Andrez' D. White, vol. i, pp. I50-51. 
the two Republican members of the board of police commissioners and the two Democratic members. The action of the Democratic members, under the prod of Tammany Hall, had served to vitiate the Republicans' endeavors to prevent fraudulent registration. ${ }^{1}$

"Choose ye this day whom ye will serve," cried the Times on election morning. It summed up its final arguments as follows:

John A. Griswold and John T. Hoffman enteres public life together as Democrats; but the former now represents Democracy as it was, and the latter Democracy as it is. It is the difference between the genuine and the sham, between honesty and corruption, between purity and Tammany. . . . If any peace-loving, fraud-lating citizen who claims to keep his neck out of the yoke of party allegiance, has had doubts hitherto how he ought to vote, surely Mayor Hoffman's proclamation ought to dispel them. ${ }^{2}$

1 For full account see New York Times. Nov. 3, 1868.

Ibid. 


\section{CHAPTER XIV}

\section{Tweed Carries the State by Fraud}

THE election over, final results showed that Grant had obtained $2 x_{4}$ electoral votes in twenty-six States to 80 in eight States for Seymour. The disparity in popular votes was not so great; Grant received $3.012,833$ or $52.7 \mathrm{I}$ per cent of the total vote, while Seymour was credited with $2,703,249$ or 47.29 per cent. The Republican majority was 309.584 or 5.42 per cent of the total vote. ${ }^{1}$ In New York State the Democrats profited from the untiring efforts of the "Ring". Grant obtained 419,883 votes, a percentage of 49.45 , while Seymour received 429,883 , a percentage of 50.55. For Governor, Griswold received 4I 4355 , or 49.40 per cent of the total vote, and Hoffman received 439,30 , or 51.6o per cent. ${ }^{2}$ In spite of the fact that Seymour

1 Tribune Almanac, 1869, p. 88.

In 1864 Lincoln received..... 2,223,035 votes, or 55.10 per cent

McClellan received ... I,8II,754 " " 44.90 " “

Republican majority.. 4 4 II,28I “ "

In 1860 Lincoln received..... I $1,866,452$ " " " 39.87 “ “

Douglas received.... I, $1,375,157$ " " " 29.37 " " "

Breckinridge received. 847.953 " " I8.I I " “

Bell received ....... $590,63 \mathrm{I}$ " " $\mathrm{I} 2.65$ " “

"Ibid., p. 57. The vote on the other State officers was:

Lieutenant Governor-Alonzo B. Cornell (Republican), 4II,670; Allen C. Beach (Democrat), 439.327; majority, 27,657.

Canal Commissioner - Alexander Barkley (Republican), 4II,522; Oliver Bascom (Democrat), 439,126; majority, 27,604.

State Prison Inspector-Henry A. Barnum (Republican), 4II,850; David B. McNeil (Democrat), 438,784; majority, 26,934 .

Clerk of the Court of Appeals-Campbell H. Young (Republican), 412,080; Edward O. Perrin (Democrat), 438,357; majority, 26,277. 
carried the State by 10,000 and Hoffman by 27,946 , the Republicans won a majority in both branches of the legislature and elected eighteen of the thirty-one Congressmen.

It would be difficult in view of admitted facts not to believe that gross frauls were committed by Tweed and his satellites. On Tuesday morning a secret circular ${ }^{1}$ from the Democratic central committee was sent to trusted Democrats throughout the State, with but one object as the Evening Post declared, to enable William M. Tweed to estimate how many votes would be needed in New York City to defeat the will of the people of the State. Samuel J. Tilden's name was signed to this circular. ${ }^{2}$ The Ezening Post could do naught but believe that the signature was a forgery, which prediction was substantiated by Tilden's repudiation of the circular on the following day in the columns of the Evening Post. ${ }^{3}$ Yet Tilden could not believe that the cir-

${ }^{1}$ New York Evening Post, Nov. 4, I868.

The circular read:

"Private and Strictly Confidential"

"Rooms of the Democratic State Committee

October 27, 1868 .

"My dear Sir: Please at once to communicate with some reliable person in three or four principal towns, and in each city of your county, and request him (expense duly arranged for this end) to telegraph to William M. Tweed, Tammany Hall, at the minute of closing the polls-not waiting for a count-such person's estimate of the vote. Let the telegraph be as follows- 'This town will give a Republican (or Democratic) majority of-.' There is of course an important object to be attained. By a simultaneous transmission up to the hour of closing the poll, but not longer waiting, opportunity can be taken of the usual half-hour lull in telegraphic communication over lines before actual results begin to be declared, and before the Associated Press absorb the telegraph with returns and interfere with individual messages, and give orders to watch carefully the count."

"Very truly yours,

"Samuel J. Tilden, Chairman."

${ }^{2}$ New York Erening Post, Nove. 4, 1868.

3 Ibid. 
cular had any such illegal motive as had been ascribed to it. His own charity, however. could not cover the multitude of sins of his fellow committeemen.

The Lnion League Club aiter the election charged that gigantic frauds had been practised in naturalization, fraudulent registration and roting. Andrew D. White and Roscoe Conkling spoke of the frands as well-known facts. ${ }^{1}$ The Tribune demonstrated how in a single ward votes were cast on more than 2,ooo fictitious names." The Sun " joined with the Tribune, the Evening Post, the Commercial Advertiser and the Times in demanding an adequate explanation of the confidential circular and a searching investigation of the frauds. The Sun also published charts which manifestly proved the frauds practised by Tammany. In New York City and Brooklyn it was a notorious fact that the ballots were counted behind closed doors in open defiance of the law. "False names in thousands were put on the registration lists, and on the strength of them repeaters went from precinct to precinct voting early and often." "

"The monstrous frauds," saicl the Vation, "are perfectly notorious. Their magnitude is such as to make it difficult to believe in their existence. and ahmost impossible to overcome their effect. Their existence is not serionsly disputed." " The Nation claimed that in New York City a total of 50,000 persons had been naturalized, 20,000 to 25.000 of whom had never gone near the courts, and ro,000

${ }^{1} C f$. Alexander, A Political History of the State of New' York. vol. iii, pp. 215-16. New York Tribune, Nov. 23. 1868. Thomas V. Cooper, American Politics, vol. iii, p. 180.

- New York Tribune, Nov. 6, 1868.

- New York Sun, Nov. 4, 5, 6, 1868.

- The Nation. Nov. 5, 1868.

s Ibid., Nov. 12, 1868. 
to 15.000 had never been sworn. ${ }^{1}$ It also claimed that 20,000 fictitious names had been registered in the cities of New York and Brooklyn."

A Congressional investigation into the New York election frauds was set on foot in pursuance of a memorial presented in the senate and the house of representatives on December I4, I868, by a committee representing the Union League Club of New York City." Nlthough the committee experienced great difficulties in obtaining records, and arrests were necessary in many cases in order to

1 The Vation, Nov. 12, 1868. Cf. New lork (ity-Goiernment Cormption, - a series of in pamphlets paying special attention to the Tweed Ring. In Columbia University Library

2The Nation, Oct. 29, I868. "The naturalization mill has finished its work for this election, having ground out 35,000 in this city alone. Of these, I0,000 are perhaps rightly admitted, I0,000 have passed through the machine without having been here five years; and the other 15,000 have never, at any rate, been near the court-room; indeed. from 5,000 to 7,000 of these latter are non-existent. This is what one of our upright judges-he was upright at one moment-did one day last week. He invited a friend who happencd to be in his courtroom to sit by him while he played a little joke. Then he left calling off the names from the list before him and proceeded to call off a long string of purely imaginary names invented by himself on the spur of the moment: 'John Smith, James Snooks, John Jones, Thomas Noakes,' and the like. For every name a man instantly answered, and took a certificate. Finally, seeing a person on the other side of the room scratching his head, the judge called out, 'George Scratchem.' 'Here,' responded a voice. 'Take that man outside to scratch,' said his honor to the usher; and resumed the more regular manufacture of voters..... At least 10.000 certificates of naturalization have been issued for the use of 'repeaters,' and scattered through the State. The total number of certificates fraudulently obtained, in this and other cities, is at least 25,000 to 30,000 . This is a heavy load for Grant to carry in this State; and may be too much for him."

For a detailed account of the election frauds of 1868 in New York City see John 1. Davenport. The election and uaturalization frauds in New York City, I860-70, p. I0/ et seq.

"See Senate Misc. Doc., no. 4, 3d. Sess., foth Cong. 
obtain testimony, many witnesses of high and low degree were questioned. The committee's report, embodied in two volumes, ${ }^{1}$ is illuminating as to the political methods in vogue under the Tweed ring.

Mr. William Lawrence, of Ohio, offered the majority report on February 23rd. The majority found: I. That many thousands of aliens had fraudulently procured, or were furnished with, certificates of naturalization which had been illegally or fraudulently issued in order that they might register and vote at the election; 2 . That thousands of certificates of naturalization were granted in the names of fictitious persons to enable persons to vote many times at the election: 3. That many hundreds voted from two to forty times or more: 4 . That extensive frauds were committed in canvassing the ballots, and that the names of Democratic voters were entered on the poll lists and counted as if such persons had actually voted, when they had not: 5 . That the accomplishment of these frauds involved gross neglect of duty and disregard for the law so great as " to evince that a criminal purpose prevailed in some of the courts, while officers and Democratic partisans of almost every grade, either by official influence, or otherwise, aided, sanctioned, or knew of and failed to prevent them." The same influences shielded the perpetrators in most cases from detection or arrest, and when arrested they have escaped all punishment through the agency of judicial officers; 6 . That through these agencies the Democratic electors of the President and Vice-President and the Democratic candidate for Governor of New York were fraudulently elected. ${ }^{2}$

${ }^{1}$ Reports of Committees of the House of Representatives, 3rd Sess., 4oth Con., vol. ii, no. 3 I, vol. i, p. I48; vol. iii, no. 4I, pp. I49-867, 1868-69.

2 Reports of Committees, 3rd Sess., 40th Cong., I868-69, vol. ii, no. 3I, pp. I-97. 
The majority found that from 1856 to 1867 the Superior Court and the Court of Common Pleas ${ }^{1}$ had naturalized an average of 9,000 persons annually. The Supreme Court did not enter into the field of competition until October 6 , I868. The results for I 868 were found to be as follows: the Court of Common Pleas naturalized 3.145, the Superior Court, 27,897, and the Supreme Court, I0,070. ${ }^{2}$

As indicative of criminal intent in high judicial piaces the majority found that the clerks ${ }^{3}$ of the Supreme and the Superior Courts had ordered from the New York Printing Company between September I6 and October 23rd, I05, C00 blank applications and 69.000 certificates. ${ }^{4}$ ln view of the probably well-known, certainly easily ascertainable fact, that the average annual naturalization called for less than Io,000 certificates, it appears strange to find 69,000 ordered. Further the refusal of Justice Barnard of the Supreme Court to sign an order which would enable the committee to investigate its records casts grave doubts on its honesty. ${ }^{5}$ Out of 39.000 blank certificates printed for the Supreme Court, 27.068 were unaccounted for on February I 7 , I $869 .^{\circ}$

It appears fron the testimony that Justice John R. Brady of the Supreme Court claimed that five minutes was necessary in order to properly examine an applicant. Judge Charles P. Daly, of the Court of Common Pleas, likewise

1 The Report spoke of the Court of Common Pleas as an honest court. Ibid., vol. ii, no. 31, p. 22.

I Ibid., vol. ii, pp. Io-I2.

- For a complete list of the various city officials in 1870 see Townsend, New' York in Bondage, pp. 4I-45.

${ }^{4}$ Reports, vol. ii, no. 3I, pp. I2-I3.

${ }^{5}$ Realizing the futility of such a move the Committee did not call Justice Barnard to testify, and he did not volunteer, in spite of the open charges against him. Ibid., vol. ii, p. 26.

"Reports, vol. ii, no. 31, p. 28 . See The Nation, March 4, 1860 . 
claimed that it took from three to five minutes. But Judge John McCunn, of the Superior Court, stated that he could examine an applicant in thirty seconds. Judge McCunn also stated that he had frequently held court at eleven to twelve o'clock at night in order to oblige those aliens who were so anxious to become American citizens.

The number of those naturalized for several days in the Supreme Court, where Justices George G. Barnard and Albert Cardozo sat, follows: 2, I09, r.868, i.856, and I. $8+2$. Colonel Archibald M. Bliss testified that he had witnessed batches of $\mathrm{I}_{5} \mathrm{O}$ to 200 foreigners brought before the bar of Justice Barnard's court and sworn in with no attempt made to identify them. A Bible was held up in the middle of a group by an attendant and only those nearby could touch it. This process was rapidly repeated many times while Colonel Bliss was there. At length an order was given to clear the room, Barnard having become aware of Bliss's presence. ${ }^{1}$ Regarding Judge McCunn's court. testimony was given to show that the applicants were not permitted to enter the court room. Gangs of witnesses alone were permitted to enter, who swore to the identity of the applicants outside: the latter were thereupon given their certificates upon payment of the fee demanded by Tammany.

The management of these huge frauds was in the hands of a naturalization committee appointed by Tammany, the chairman of which was Judge Moses D. Cale, whose uprightness and purity of character the minority report commended. This committee had its main office at the corner of Centre Street and Tryon Row, with branch offices thronghout the city. A subcommittee to handle the German naturalization was presided over by one Benjamin $B$. Rosenberg. ${ }^{2}$ with an office at 6 Centre Street. This latter

'Reports, vol. iii, no. 4I, pp. I 19-120: vol, ii, no. 3I, p. 24.

- Afterwards indicted for fraud in connection with naturalization. 
office appears from the testimony to have been the most active in procuring from the Supreme Court, selling and distributing certificates, and "red tickets" prepared by Tammany to pay the clerk fees. ${ }^{1}$

Additional evidence was advanced by the majority to show how the gangs of repeaters were able to cast numerous ballots. To bring this about proved easy for Sheriff James O'Brien, who appointed 2,000 toughs as special deputies on election day. ${ }^{2}$ Wherever it was attempted to stop ballot-box stuffing, or a repeater was chatlenged, the daring Republican watcher was promptly subjected to the arts of the Bowery tough. ${ }^{3}$ In cases where arrests were made the party under arrest was taken before one of the courts subsidized by Tweed, practical immunity from punishment being the result. ${ }^{4}$

One gathers an entirely different impression when considering the minority report of the Congressional committee. ${ }^{5}$ But two members of the committee concurred in this report. namely, Mr. M. C. Kerr and Mr. L. W. Ross, who spoke of the facts of the majority report as a stock of "stale slanders" gleaned from witnesses who were liars, swindlers and altogether beneath contempt. The minority report attempted to cast doubt on the veracity of all the majority's witnesses through having impeached certain of them, doubtless with witnesses also impeachable. The testimony of Nayor . 1. Oakey Hall ${ }^{6}$ and of Tweed himself ${ }^{7}$ was en-

'Reports, vol. ii, no. 3I, p. 15; also vol. iii, no. 4I. question no 33; pp. 29, 699. 685, 2062, 2453, 3477, 3409, 3006. 3422, 3004. 3547.

2 Ibid., vol. ii, no. 31, p. 55.

"Ibid., vol. ii, pp. 47, 49, 50 Cf. Evidence. pp. 362, . 86.

4 Reports, no. 3i, p. 57.

'lbid., pp. 99-148.

- Ibid.. no. 4I, p. 335 .

'Ibid., p. 266. 
larged upon as proof that only minor irregularities had occurred in the election. The minority admitted that certain frauds had occurred but asserted that the fraudulent vote in the election of 1868 did not exceed I,500 to 2,000 and of that number there were as many Republicans as Democrats concerned.

The minority report was Hobbesian in the extreme: "the very constitution of man inclines him," it said, "be he Republican or Democrat, to villainous devices of all kinds to advance his selfish interests." It then attempted to show that the majority had used figures unfairly ${ }^{1}$ and that the Republicans were directly responsible for having produced any congestion in the naturalization courts, through having passed a law in I 865 which required every naturalized person to show a certificate before he could register and vote. Moreover, the minority explained the increased naturalization on the grounds of increased population and had a plausible answer for the greater output in naturalizations by the Supreme and Superior Courts than the Court of Conmmon Pleas by pointing out that the former courts had a greater number of judges than the latter. Chief emphasis was placed by the minority on the following statement: "IVe invite especial attention to the important fact which we desire to emphasize, that it is not, in our entire record, satisfactorily shown by credible or unimpeached testimony, that any one or more clerks, judges, or other officers of any of the courts was, with knowledge, directly or indirectly a party to or participant in a single one of these frauds." 2

Regarding the election frauds in New York City the Commercial Advertiser was inclined to blame the Republicans for lack of the proper organization to prevent fraud. ${ }^{3}$

\footnotetext{
1 Report, no. 31, p. 124.

"Ibid., p. II4.

- New York Commercial Advertiser. Nov. 4. I868. Cf. P. B. Sweeny, On the ring frauds and other public questions: taken from his intervicus and other papers (New York, 1894), passim.
} 
It stated that in many of the Democratic strongholds no challengers were provided nor were lists checked off. It was severe on Republican inspectors of elections and poll clerks many of whom, it claimed, must have connived with the Democrats in fraud, or have been woefully stupid or timid. ${ }^{2}$ Moreover, it poked fun at the Union Republican central committee, which drew up windy resolutions, and gave the committee credit for a large share of the defeat of the people by ballot-box stuffing because it failed to provide proper election machinery. ${ }^{2}$

On the other hand, the Sun, ${ }^{3}$ the Evening Post, ${ }^{4}$ the Times ${ }^{5}$ and the Tribune, ${ }^{6}$ were loud in their denunciations, demanding a thorough investigation and punishment for those convicted. From a perusal of the World immediately after election one would never suspect that there had been anght irregular in the vote. Later it denied in toto any ballot-box stuffing on the part of the Democrats and laughed at the absurdity of the Radicals having a majority in New York City. ${ }^{7}$

The editorial opinion as to the results of the election varied. The Times predicted that the Reconstruction measures would now have a fair trial. It believed that the Democrats of the State had cared comparatively little for the Presidency which they had despaired of winning after the October elections, but that they were abundantly consoled over the defeat of Seymour by the election of Hoffman. Tammany had played its game with successful

${ }^{1}$ New York Commercial Adz'ertiser, Nov. 4, 1868.

2 Ibid., Nov. 5, 1863.

${ }^{3}$ New York $S u n$, Nov. 4-Io, I868.

${ }^{4}$ New York Evening Post, Nov. 3-8, i 868.

${ }^{5}$ New York Times, Nov. 3-12, 1868.

- New York Tribunc, Nov. 3-10, I868.

' New York World, Nov. 5, I868. 
adroitness in dictating the national platform and candidates, thus destroying all chances of a national success, and bending all of its energies to the election of Hoffman. ${ }^{1}$

The Evening Post saw in Grant's election the determination of the American people that Congress must not be coerced. " "The bare success of a candidate," thought the Sun,

whose platform and policy are embodied in the phrase, 'Let us have peace,' will cause the waves of passion and violence in the Southern States to sink in repose... As to reconstruction, the triumph of Grant and the defeat of Seymour, in a manner so signal and conclusive, will of themselves solve the problem. ${ }^{3}$

Next to turning his editorial batteries against the fratids perpetrated on election day in New York City, Horace Greeley found huge delight in condoling with Horatio Seymour over his defeat. It may be that Greeley's tender ministrations to Seymour loomed larger to him than did his concern over the debauchery of the suffrage. Nationally Greeley saw in the election of Grant the settlement of the questions of "Union, Peace and Equal Rights for all men"..

Thurlow Weed found that the campaign had been apathetic considering the tremendous issues at stake, the character of the opposing leaders and the unsettled condition of the country; when contrasted with previous presidential contests. $^{5}$ Weed conceived two reasons for this, namely, that the course of Tammany in their national convention together with the platform and candidates put forth de-

${ }^{1}$ New York Times, Nov. 5, i868.

${ }^{2}$ New York Evening Post, Nov. 4, I868.

${ }^{3} \mathrm{Ncw}$ York Sun, Nov. 4, I868.

4New York Tribune, Nov. 6, I868.

${ }^{5}$ New York Commercial Advertiser, Nov. 3, I868. 
feated the Democrats nationally from the start; and second, that the prolonged excitement through which the country had gone at the beginning of the campaign had reacted against the Democrats. ${ }^{1}$ That Grant would furnish a careful administration and would rehabilitate the Southern States with their rights in the Union, was the conviction of Weed. ${ }^{2}$

Still clinging to its old love, Chief Justice Chase, the Herald in commenting on the election expressed its belief that Chase might have won over Grant had he been nominated. ${ }^{3}$ The suggestion of Chase's name was considered by the $W$ orld to have been in every way unfortunate for the candidacy of Seymour, in preventing the practical views of Seymour from receiving a fair hearing before the country in the early summer. ${ }^{4}$

The World especially praised Seymour for pitching the canvass in a moderate key, but it credited him with an error in so long and so persistently refusing to permit the use of his name as a candidate. It congratulated the Democrats of the United States upon the battle they had fought in behalf of "Representative Self-Government, Liberty and Economy, the Union and its Peace." "With all our hearts we applaud and honor them for the manful and unwearied blows they have dealt at disunion, revolution, military despotism, corruption and fraud." In giving Seymour its cordial good wishes as he re-entered private life, the World claimed that the Democratic party would be forced to acknowledge him as the wisest and most sagacious of all Democratic leaders when sufficient time had elapsed. ${ }^{8}$

1 New York Commercial Advertiser, Nov. 3, I868.

2 lbid., Nov. 4, I868.

${ }^{3}$ New York Herald, Nov. 5, I868.

4 New York World, Nov. 5, 1868.

${ }^{5}$ Ibid., Nov. 4, 1868.

${ }^{6}$ Ibid., Nov. 5, I868. 
May we leave the question, has time borne out the World's prediction?

THE NEW YORK CITY CHARTER ELECTION OF I 868

On Tuesday, December 2, I868, the election for charter officers of New York City was held. The election passed' off quietly and created little interest. Republicans were nominated for all the offices, but having exercised themselves thus far, apparently, the Republicans and enemics of Tammany considered it useless to exert themselves further. As the vote shows most of them remained away from the polls.

The candidate for mayor was to be elected for one year only to fill out the unexpired term of Hoffman. On Monday, November 23rd, Tammany nominated A. Oakey Hall, who was then representing it as district attorney. Hall was one of Tweed's bright young men, being advanced to the mayoralty so that he could act as a polished, genteel headpiece for the "Ring". Four years later upon the overthrow of 'Tweed, Hall was forced to flee to Europe.

The Republicans nominated Colonel Frederick A. Conkling, ${ }^{1}$ formerly a prominent merchant, an ex-member of the Assembly and of Congress, who accepted the nomination in face of inevitable defeat. Neither the Democratic Union party nor the Mozart Hall faction of the Democrats was able to find a candidate to run against Tammany. At length, on November 27th, after the Hon. Andrew $H$. Green and the Hon. John Kelly ${ }^{2}$ had declined, Conkling received the nominations of the Constitutional Union Democracy and of the Democratic Union party. ${ }^{3}$

${ }^{1}$ Colonel Conkling had served in the Civil War at the head of the 84 th Regiment of National Guards.

${ }^{2}$ The Democratic Union party had made a strong pre-convention fight to nominate John Kelly for Mayor on the Tammany ticket. On its failure Kelly withdrew.

${ }^{3}$ New York Sun, Nov. 28, I868. 
For corporation counsel Tammany renominated Richard O'Gorman. Mozart failed to agree to O'Gorman's renomination because, as it appears, O'Gorman was not willing to give Fernando Wood a rental of $\$ \mathrm{I} 8,000$ for some rooms on Nassau Street. ${ }^{1}$ The Republicans experienced difficulty in finding a person who would accept the barren honor of a nomination for corporation counsel. Nevertheless, on November 27 th, Dorman B. Eaton was persuaded to accept. Aldermen, assistant aldermen, school commissioners and school trustees were among the other officers to be voted for. Practically no campaigning was done by either side, ward conflicts stirring up what little interest was displayed.

For Mayor, A. Oakey Hall received a total of 75,109 votes to 20,835 cast for Frederick A. Conkling. ${ }^{2}$ Richard O'Gorman was elected over Dorman B. Eaton by a majority of 53,9I 5 votes. $^{3}$ Between the November and December elections the Republican vote in New York City fell off 22,537 or nearly 52 per cent of the vote for Governor, while the Democratic vote fell off $37,4 \mathrm{I} 3$ or 32.26 per cent. ${ }^{4}$

The Sun was the only leading paper which ran editorials on the charter election. Though beaten, it maintained that neither the Republican party nor its candidates had anything to regret in connection with the contest. ${ }^{5}$ The Herald made but a perfunctory plea for good government and exhibited no surprise at the election results. The Times, although it considered Hall a genial gentleman, a man of reading and of culture, personally honest and always disposed to do what the public welfare might require, stated

\footnotetext{
1 New York Sun, Nov. 24, I868.

2 Tribune Almanac, 1869, p. 62.

3 O'Gorman received 74,704, Eaton, 20.789.

- Tribune Almanac, op. cit.

5 Nvew York Sun, Dec. 2, I868.
} 
406 POLITICAL HISTORY OF NEW YORK STATE [406 that he would have as little to say in the management of the City as the first man he would meet on Broadway. ${ }^{1}$ The Times prediction proved only too true.

${ }^{1}$ New York Times. Dec. 2, I868. 


\section{CHAPTER XV}

\section{Conclusion}

During the period from the close of the Civil War to 1869, when the Democrats gained control of the State administration, the national administration at Washington was forced to give New York, among the Northern States, its chief attention. Instead of the Empire State, with its great wealth and resources, giving potent aid to the national administration in attempting a speedy settlement of the Reconstruction problems, the State was divided into two hostile camps over the question of the President's policy. New York, indeed, from I 865 to I 869 was in the process of a political reconstruction, which corresponds with and bears relationship to the wider early Reconstruction period in the South.

The closeness of this relationship may be suggested. New York, on the one hand, was the home of one of the most bitter and active groups hostile to President Johnson's Reconstruction policy, namely, Horace Greeley, Reuben E. Fenton and Roscoe Conkling. Likewise, on the other hand, it was the home of the President's strongest group of supporters, the New York triumvirate, composed of William H. Seward, Thurlow Weed and Henry J. Raymond. Johnson relied upon the support of Raymond in Congress to defend the Presidential policy, and upon Seward and Weed to hold the balance in New York State against the Radicals.

In the Philadelphia Convention, August, I866, we find the most important expression of political transformation 
which made the period from 1865 to 1869 distinctive in political annals. The Philadelphia principle was to a degree foreshadowed by the change of policy which the Democrats of New York developed in 1865 . The metamorplosis was complete. With one stroke of the pen the Democrats freed themselves from the War issues and became firm supporters of the President's policy. With one stroke of the guillotine they rid the party of the men responsible for the party's defeat. The Democrats, as firm disciples of President Johnson's policy, were thus prepared to coalesce with the Philadelphia movement in 1866.

It has been shown how Johnson's attempt to patch his political fences by a union of Democrats and Conservative Republicans failed to win for him the necessary support in Congress to carry out his policy. However, in New York the Philadelphia principle had its most fruitful results. The Albany convention in I866 was the New York expression of the Philadelphia principle. However, the New York Democrats, who had emerged from the War with at least as much strength as when they entered, due largely to the Seymour administration and the draft riots, were merely trimming their sails for the breeze. The Democratic transformation was of the tongue, rather than the heart. Hoffman, the Tammany candidate, who was nominated by a ruse over General John A. Dix, the logical candidate of the Philadelphia principle, represented neither the principles nor the purposes of the Philadelphia Convention.

To many the question presented in this period was, whether the State would be safer in the hands of the Conservative Republicans and Democrats of the Dix type, than under Fenton and the Radicals. The Democratic leaders of the State appeared to be thoroughly alarmed over the distance to which the Philadelphia movement was carrying them. In their convention of 1866 , and in the campaign, 
the Democratic leaders made it apparent that they had endorsed the Philadelphia movement to get into power-not to give Dix and the Conservatives of the Republican or Democratic parties the control of the State. Nevertheless, it must be said that the New York Democrats appeares to have been sincere in their endorsement of the President's policy.

Moreover, the Philadelphia principle was doubly a failure in that its leading backers lost caste with the Republican party. Raymond failed to lead the President's policy to victory in the House, and as a result of his Philadelphia speech was read out of the Republican party, although, at this day when the Reconstruction passions are largely allayed it is difficult to find the objectionable features in his address. Seward, as the originator, in part, of Johnson's policy and as the defender of the constitutionality of the President's vetoes, cane in for his share of unpopularity. Seward's friends, at first, thought that he remained in the Cabinet to dispose of diplomatic questions which the War had left unsettled, but after his speech at Auburn on May 22. I866, and finally his address to his neighbors on October 3I, I868, his open support of Johnson and weak attempts to reconcile the jarring elements shut him off completely from the party which he had so gallantly led. That Seward's grasp had become nerveless was apparent. It caused a wave of sadness to sweep over many of his sometime admirers to see the inroads of age, but, especially, to see his marytrdom to the cause of an impolitic and unyielding President. Thurlow Weed remained true to the Philadelphia principle in the campaign of I866, voting for Hoffman. Raymond, however, could no longer stand the inconsistencies of the President's course and gave the support of the Times to the Republicans.

Although the Democrats did not have their machine suf- 
ficiently organized to elect Hoffman in 1866 , the manifest growth and strength of the Democracy in New York State should have given the Republicans warning, but they gave no heed. Seward was discredited, Conkling was promoted to the United States Senate, that the State might have a voice, and Fenton was conspicuously trusted. The faith of the Republicans in Fenton proved to be ill-placed. Fenton was of low origin, a man of small calibre and a politician merely. To his mal-administration may be credited, for the most part, the loss of the State to the Democrats, and the furnishing of the opportunity for the Democrats to give their period of control succeeding is68 an unending notoriety.

The first distinctive feature, then, of this period from I 865 to I869 in New York State was the attempt of the Democracy to rehabilitate itself and co-operate with the Southern States against Radical Reconstruction under cover of a union with the Conservative Republicans, based on the Philadelphia platform. The second distinctive feature of this period from I865-I869 was the rise in power of the Democrats of the State under the direction of Tammany Hall. Hoffman's appearance in State politics and his election to the governorship in I 868 marked the beginning of a new era in Democratic control.

In spite of the fact that fraudulent registration and illegal voting materially aided in the Republican defeat of I867, the presence of large Democratic gains up-State showed that the Republican defeat was due to other causes. Among these causes which produced the tidal wave of public sentiment in favor of the Democrats may be attributed broadly: the general disgust of the Conservative Republicans and Democrats with the leadership of men like Stevens. Sumner and Greeley; the treatment of Reconstruction to the exclusion of other matters of national in- 
terest; the loss of faith in the Republican State party because of corruption in office and corrupt nominees; the Republican advocacy of the excise law and the metropolitan ordinances; the abandonment of the principles of the War irrespective of party, and the general apathy within the Radical ranks. Republican sentiment in general showed that the rebuke was merited on account of their cowardice on negro suffrage in the Constitutional and State conventions, and because of the host of political adventurers who had been attracted to the party for selfish purposes.

The reality and strength of the organization which the Democrats had been building during this period of transformation from I 865 to I 869 was made manifest when the State was carried by Seymour over Grant by I0,000 votes and by Hoffman over Griswold by 27,946 . It is true that the Republicans anticipated huge naturalization frauds, that the United States District Court took cognizance of the matter, that the secret circular was sent out, and that undoubted frauds were revealed by the Congressional investigation committee; nevertheless, it is equally true that the Democrats of New York City and up-State had reorganized and rehabilitated their party to the extent that they were able to effectively defeat the Republicans of the State by taking advantage of the public disgust with the Radical Fenton administration. The mal-administration of the canals under Fenton, the venality of the legislature as revealed in the Erie war, and the notoriously corrupt character of many of the Republican candidates and officials recognized by Fenton, made a stench in the public's nostrils which counteract the remembrance of Copperheadism.

The Democratic victory in I868 in New York, then, marks the end of an era of readjustment and transformation in the Democratic ranks and the beginning of a new era in the control of the State. The exposures of $187 \mathrm{I}$ 
which resulted in the overthrow of the Tweed ring, disclosed the powerful political mechanism which had been constructed in the State under Tammany from I865-I869. Likewise, the prosecution of the canal ring in $1874-5$ by Tilden disclosed roots which extended deeply into Fenton's administrations from I864-I868. It is to be seen, thus, that both parties were open to and suffered from the manipulations of corrupt men who were able to make use of the transitory period from I865-I869 to organize under cover of the general social, industrial and political disturbance of the period. It is safe to say that neither a Tweed ring, nor a Fenton administration would be tolerated at the present day. The plane of public sentiment is unquestionably higher than it was during the chaotic days of the early Reconstruction period, when fraud was rife in both the State and national administrations.

In I 868 we find new groupings of party leaders. Among the Democrats, Horatio Seymour had finally lost countenance as a national leader. In 1865 the Republican party was suffering from the dissensions largely attributabls to Thurlow Weed through the Civil War period, but by :868 he had practically lost his power with both the Democrats and Republicans. Samuel J. Tilden was aspiring to Seymour's place in the Democratic national party, a position which Tilden attained in the following decade. In New York State, Hoffman was the nominal head of the Democracy. However, as is known now, and as was generally suspected then, Tweed was the power behind the throne, a power, however, which was closely contested by the upState Democrats and by Samuel J. Tilden.

Among the Republicans in I868, we find that the powerful machine which Fenton had constructed had been chiefly destroyed. Notwithstanding, Fenton was able to secure his election to the United States Senate in January, 
I869, where, however, he came into abrupt collision ivith Roscoe Conkling. The State machine which Conkling had been organizing in opposition to Fenton beginning in 1867 , was unquestionably in the ascendant in 1868 and was dominant in the era following i868. Horace Greeley, although he made an uncertain leader, was still a power in Republican ranks through his control of the Tribune. His insatiable desire for public office led him to defeat at the hands of Conkling in 1867 , and, also, in I868 through the treachery of Fenton. Nevertheless, he covered his wounds, biding his time until he led the Liberal Republican movement in I872. Henry J. Raymond kept the Times in accord with the Republican party, but he remained outside the breastworks personally, making no attempt to renew his former relationship with the party. Blaine claimed that Raymond's parliamentary failure was a keen disappointment to him and tended to cut short his useful life.

With the failure of the Philadelphia principle, and of the Democrats singly, to evolve out of chaos of the period of I865-I869 an organization sufficient to overcome the popularity of a great military hero, the Radicals were assured that they could drink the cup of vengeance to the full. Had Seymour and Blair been elected in I868, it is fair to assume that certain of the previous Reconstruction acts of the Radical Congress would have been abrogated or amended, and that the readjustment of the difficult situations in the South would have followed more natural lines. What effect this would have had upon the political and economic condition of the South it is impossible to state. It would seem, nevertheless, that there would have been less bloodshed, less sectional hatred engendered, a saner and speedier conception of what was for the best interests of the nation as a whole, had an administration been returned other than that of the Radicals. 


\section{BIBLIOGRAPHICAL NOTE}

The bibliography which follows is aimed merely to suggest the main groups of material consulted on the period. No attempt has been made at completeness.

\section{NEWSPAPERS}

*Albany Argus ............................ I $865-68$

*Albany Evening Journal ......................... I855-68

Albany Freeholder ................................ I845-54

Auburn Advertiser ............................. 1865

*Binghamton Daily Republican ..................... 1865-68

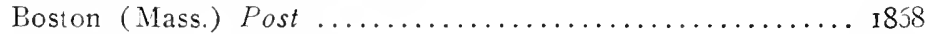

Boston (Mass.) Transcript ......................... I $86_{5}$

Bridgeport (Conn.) Standard ....................... I85s

Brooklyn Union ................................ 1863

*Broome Weckly Republican ....................... I865-68

*Buffalo Commercial Adiertiser ..................... I865-68

Buffalo Daily Courier ........................... I $865-68$

* Buffalo Express ............................. I $865-68$

Cincinnati (O.) Commercial ....................... I8 8

Cincinnati (O.) Gazette ......................... I 869

Cincinnati (O.) Enquirer ....................... I $8 € 8$

Charleston (S. C.) Courier .................... I 867

Charleston (S. C.) Mercury ................... I 868

Chautauqua Democrat ...................... I 867

Chicago (Ill.) Republican ..................... I 867

Chicago (Ill.) Times ......................... I 868

Chicago (Ill.) Tribune ....................... I 858

Columbus (O.) Statesman ..................... I 868

Des Moines (Ia.) Statesman ..................... I 868

Elmira Daily Advertiser ......................... I 865

Hartford (Conn.) Courant ........................ I868

Hartford (Conn.) Times ....................... I 868

Hudson Register ................................ I866

Lancaster (Pa.) Intelligencer ................... I 868

Newark (N. J.) Democrat ....................... I 868

Newburgh Press ............................ I856

$4 \mathrm{I} 4 \quad$ [4I4 
New York Citizen ............................. I 868

*New York Commercial Advertiser .................... 1865-68

*New York Evening Post ....................... I865-68

*New York Herald ............................ I865-68

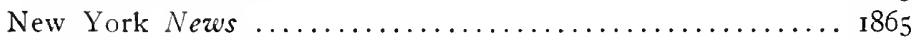

*New York Sun ............................. I867-68

*New York Times ............................ I865-68

${ }^{*}$ New York Tribune ........................... I864-68

*New York Vorld ........................... I865-68

*Ogdensburg Daily Journal ....................... I865-68

Penn Yan Clironicle ............................. I857

Philadelphia (Ра.) Press .......................... 1868

Providence (R. I.) Journal ........................ I 1868

*Rochester Daily Democrat ...................... I855-68

* Rochester Daily Union and Advertiser ................ I855-68

Springfield (Mass.) Republican ..................... I 865,68

*Syracuse Daily Courier and Union .................. I865-68

*Syracuse Daily Journal ......................... I865-68

*Syracuse Daily Standard ......................... I855-68

*The Independent, New York ...................... I866-68

The Universe, Philadelphia ........................ 1865

Toledo (O.) Blade ................................. 1868

Troy Daily Times ............................... 1865

Troy Press ................................... 1866

*Utica Daily Obscreer ............................. I865-68

*Utica MIorning Herald ......................... I865-68

Washington (D. C.) Chronicle .................... I867

Washington (D. C.) National Intelligencer .............. I868

Wilmington (N. C.) Journal ....................... I 868

The starred papers in the above list have been closely followed for the period. Of the New York City papers: the Times (Henry J. Raymond), the Tribune (Horace Greeley), and the Ezening Post (Parke Godwin), were found to be the most reliable Republican organs; the IVorld (Manton Marble), the only reliable Democratic organ; the Herald (James Gordon Bennett), purporting to be independent and paying chief atiention to politics, was in a state of unstable equilibrium; the Commercial Advertiser (Thurlow Weed), was quasiDemocratic, independent and Republican at different periods; the Sun (Charles A. Dana), claiming to be independent developed decided leanings towards Democracy; and The Independent (Theodore Tilton), although it represented the religious and conscientious part of the community, belied its name, for its editorials were pre-eminently partisan. The up-State journals of both parties were apt to follow the editorial trend of the New York City papers. There were several 
notable exceptions, however, to this statement. Although Thurlow Weed had ceased his control of the Albany Evening Journal, that organ still exerted a great control over the State. William Cassidy, of the Albany Argus, was perhaps the leading Democratic up-State editor. Ellis H. Roberts, of the Utica Morning Herald, and Carroll E. Smith of the Syracuse Daily Journal, were the rivals for the editorial leadership of the up-State Republican press. All three were molders of public opinion.

\section{MAGAZINES}

American Historical Review. The, It vols. N. Y., 1910. Harper's it'eckly, 1865-68. Harper Brothers, N. Y.

Nation, The, 1865-68, vii vols. E. L. Godkin \& Co., N. Y.

Tribune Almanac. New York, I864-68.

World Almanac. New York, I865-68.

\section{LAWS-NEW YORK STATE}

for the following years: 1832, , 41 , ' 43, ' 44, , 45, ' 46 , ' 50, ' 54, ' 55, ' 56, ' 57 , '60, '6r, '64, '65, '66, '68, '70, '92, '96 and '98.

\section{CASES}

Board of Excise $\tau$. Merchant, I03 N. Y. I43.

Dawson $\approx$. Horan, 5I Barb. 459.

Knight $\because$. Campbell, 62 Barb. I6.

Metropolitan Board of Excise $\%$ John Harris et al., 34 N. Y. 657.

People $\approx$. Burleigh, I N. Y. Crim. Rep. 522.

People v. Clarke, I3 N. Y. 378.

People v. Grant, I2 How. Pr. 83 .

People $v$. Lyon, 27 Hun. I8o.

People $\%$. Van Rensselaer et al., 9 N. Y. 291.

Rodman v. Munson, 13 Barb. I88.

Wynehamer z'. People, I3 N. Y. 378.

\section{DOCUMENTS}

Annual Report of the Adjutant General of the State of New York. Albany, 1865.

Annual Report of the American Historical Association. New York, 1886 et seq.; Washington, I 890 et seq.

Annual Report of the Chamber of Commeree, ii parts. New York, 1865.

Annual Report of the City Superintendent of Schools. New York. I $865-66$.

Annual Report of the Finance Committee of the Board of Education. New York. 1865-66. 
Annual Report of the Superintendent of the Banking Department of the State of Neze York. Albany, I866.

Assembly Documents. Albany, I840-55.

Assembly Documents. Albany, 1866 .

Assembly Documents. Albany, 1868 .

Census of the State of $\Lambda_{c} w$ York for 1865 , edited by Franklin B. Hugh. Albany, I866.

City Mission and Tract Socicty Reports. New York, 1865.

Constitutional Convention of 1867-68, The. Documents. Albany, 1858 .

Constitutional Convention of I894, Rezised Records of the. Albany, 1 is9.

Constitutional Convention Proccedings, I8.76. Albany, I847.

Constitutional Proceedings and Debates. Albany, 1868.

Eighth Census of the United States. Washington, I860.

Executive Documents, Ist Sess., 39:h Cong. Washington, I865.

Gasetteer of the State of New York, edited by Franklin B. Hugh. Albany, 1873 .

Journal of the Constitutional Commission of 1872-3. Albany, 1873 .

Legislatice Assembly Journal, Albany, 1846.

Legislatiz'e Assembly Journal, Albany, 1864.

Messages and Papers of the Presidents, edited by James D. Richardson, $x$ vols. Washington, 1896.

Messages from the Gozernors, State of New York, edited by Charles Z. Lincoln, xi vols. Albany, 1909.

New York State Comptroller's Report. Albany, I866.

Reports of Committees of the House of Representatives, $3 \mathrm{rd}$ Sess., 4oth Cong. Washington, 1869.

Report of the Committee on Voluntecring of the County of New York. ii vols. New York, I866.

Report of the Conncil of Hygiene and Public Health of the Citizens Association of New York upon the sanitary condition of the city. New York, 1865.

Report of the State Commissioner of Banks. Albany, I867.

Report of the Superintendent of Public Instruction. New York 1866. Selected Documents of United States History, edited by William MacDonald, iii vols. New York, 1907.

Senate Documents. Albany, I835-1851.

Senate Documents. Albany, 1865.

Senate Documents. Albany, I866.

Senate Documents. Albany, 1868.

Senate Documents. Albany, 1869.

Senate Executive Documents, Ist Sess, 39th Cong. Washington, I866.

Senate Miscellaneous Documents, 3rd Sess., 4oth Cong. Washington, I 869. 
Temperance Convention, Proceedings of the Fifth National, I865. New York, I865.

Temperance Concention, Proceedings of the Sixth National, I868. New York, I868.

United States Congress Report, New York clection frauds, Feb. 23, I869, edited by William Lawrence. Washington, I869.

\section{MISCELLANEOUS}

HISTORIES, WORKS, SPEECHES, AND BIOGRAPHIES OF CONTEMPORARY STATESMEN AND POLITICIANS

With the exception of Alexander, A Political History of the State of New York, vol. iii, which covers the period of this monograph in a brief popular treatment, most of the books listed below contain little of direct value for our purpose. Indirectly they are of value in giving side-lights on the various politicians, and the general political movements of the State in relation to the broader national movements.

Adams, Jr., Charles Francis, Chapters of Erie. Boston, I871.

Alexander, De Alva Stanwood, A Political History of the State of New York, iii vols. New York, Igog.

Appleton's Anmual Eneyclopedia or The American Annual Cyelopedia. New York, I865-9.

Autobiography of Andrew Dickson White, ii vols. New York, 1905. Autobiography of Olizer Otis Howard, ii vols. New York, I907.

Badeau, Adam, Grant in Peace. Hartford, I887.

Bancroft, Frederic, Life of Seward, ii vols. New York, I9oo.

Bancroft, Frederic, The Negro in Politics. New York, 1885.

Bench and Bar of New York. History of the, edited by Board of Editors, ii vols. New York, I 897.

Bigelow, John, The Life of Samuel J. Tilden, ii vols. New York, I895. Biography, The National Cyclopedia of American, xv vols. New York, I893-9.

Bishop, Joseph Bucklin, Our Political Drama. New York, I904.

Blaine, James G., Twenty Years of Congress, ii vols. Norwich, Conn., I 884 .

Breen, Matthew R., Thirty Years of New York Politics. New York, I899.

Brummer, Sidney D., A Political History of New York during the Ciarl lWar. New York, IgII.

Burgess, John W., The Civil War and the Constitution, ii vols. New York, 1906.

Cary, Edward, George William Curtis. New York, I894.

Clews, Henry, Fifty Years in IVall Street. New York, 1908. 
Conkling, Alfred R., The Life and Letters of Roscoe Conkling. New York, i\&\&9.

Cook, Theodore P., The Life and Public Services of Samuel J. Tilden. New York, 1876.

Cooper, Thomas V., American Politics. Chicago, Ill., I882.

Cox, Jacob Dolson, Military Reminiscences of the Civil War, ii vols. New York, Igoo.

Crapsey, Edward, The Nether Side of New York. New York, I872.

Croly. David G., Seymour and Blair. (campaign book). New York, IS68.

Cullum, Shelby M., Fifty Years of Public Service. Chicago, Ill., I9I I. Curtis, Francis, The Republican Party, 1854-1904, ii vols. New York, 1904.

Dana, Charles Anderson, Recollections of the Civil War. New York, I 898 .

Davenport, John I., Population of New York. New York, I884.

Davenport, John I., The Election and Naturalization Frands in New York City, 1860-70, Ist ed. New York, I894.

Dawes, Anna Laurens, Charles Sumner. New York, I898.

Dewitt, David Miller, The Impeachment and Trial of Andrew Johnson. New York, 1903.

Dilla, Harriet M., The Politics of Michigan, I865-1878. New York, IgI2.

Drew, Sketch of the Life of Daniel, The National Cyclopedia of American Biography, xi, pp. 502-3. New York, Igor.

Dunning, William A., Essays on the Civil War and Reconstruction. New York, 1904.

Dunning, William A., Reconstruction Political and Economic. New York, 1907.

Encyclopedia of Contemporary Biography of New York, 4 vols. New York, I887.

Fairlie, John Archibald, Centralization in New York. New York, 1898.

Fiske, Stephen, Off-Hand Portraits of Prominent New Yorkers. New York, I884.

Fite, Emerson David, The Presidential Compaign of 1860 . New York, IgII.

Fleming, Walter L., Documentary History of Reconstruction, ii vols. Cleveland, O., 1906.

Garner, James Wilford, Reconstruction in Mississippi. New York, IÇOI.

Godwin, Parke, Life of Bryant. New York, I883.

Gorham, George C., Life and Public Serviccs of Edwin M. Stanton, ii vols. Boston, I8s9.

Greeley, Horace, Recollections of a Busy Life. New York, I868. 
Greeley, Horace, The American Conflict, ii vols. Hartford, Conn., I866.

Hadley, Arthur T., Railroad Transportation. New York, 1908.

Hall, A. Oakey, Horace Greeley decently dissected in a letter on Horace Greeley addressed by A. Oakey Hall to Joseph Hoxie. New York, 1862.

Hall, William Edward, A Treatise on International Law, 5th ed. Oxford, 1904 .

Halstead, Murat, Political Conventions of I860. Compiled from correspondence of the Cincinnati Commercial. Columbus, O., I860.

Harlow, S. R., and Hutchins, S. C., Life Sketches of State Officers, Senators, and Assemblymen of New York in I868. Albany, IS68.

Hart, Albert Bushnell, Salmon Portland Chase. Boston, I89g.

Herbert, Hilary Abner, Why the Solid South. Baliimore, I89o.

Hoar, George Frisbie, Autobiography of Serenty Years, ii vols. New York, 1903 .

Hovey, Carl, The Life Story of J. Pierpont Morgan. New York, IgII.

Johnson, Emory R., American Railway Transportation. New York, I908.

Johnston, Alexander, and Woodburn, James Albert, American Political History, ii vols. New York, I905.

Julian, George Washington, Political Recollections 1840-1872. Chicago. I 884 .

Lalor, John J., Cyclopedia of Political Science, iii vols. New York, I 893 .

Lewis, Alfred Henry, The Boss and how he came to rule New York. New York, I903.

Lieber, Francis, Changes in the present Constitution of New York. New York, I867.

Lieber, Francis, Cizil Liberty and Self-Gozernment, ii vols. Philadelphia, I853.

Lincoln, Charles Z., Constitutional History of New York, v vols. New York, I906.

Livingston, John, The Erie Railway: Its History and Management. Pamphlet No. Io of ii vols. New York, I875.

Lothrop, Thornton Kirkland, William Henry Seward. Boston, I\&g9.

McCabe, James Dabney, Life and Public Services of Horatio Seymour, (campaign book). New York, i868.

MacCabe, James Dabney, The Secrets of The Great City. Philadelphia, I868.

McCall, Samuel W., Thaddeus Stezens, edited by J. T. Morse. Boston, I899.

McClure, Colonel A. K., Recollections of Half a Century. Salem, Mass., 1902. 
McCulloch, Hugh, Men and Measures. New York, I888.

McKee, Thomas Hudson, The National Conventions and Platforms of all Political Parties, I789-1900. Baltimore, I900.

McLaughlin, J. Fairfax, The Life and Times of John Kelly. New York, 1885 .

McPherson, Edward, A History of Reconstruction, and ed. Washington, 1875 .

Magoon, Charles E., The Law of Civil Government under Military Occupation. Washington, Ig02.

Mathews, J. M., Recollections of Persons and Events in New York. New York, IS65.

Maverick, Augustus, Raymond and New York Journalism. Hartford, Conn., I870.

Mott, Howard H., Bctween the Ocean and the Lakes; the Story of the Erie. New York, I\$g9.

Murray, David, The Anti-Rent Episode in the State of New York. (In the American Historical Association Annual Report, I896, i, pp. I37-173).

Myers, Gustavus, The History of Tammany Hall. New York, I901.

Nasby, Petroleum V., (David Ross Locke), Swingin' round the Cirkle. Boston, I867.

New York City-Government Corruption, A series of 19 pamphlets paying special attention to the Tweed Ring. Columbia University Library no. 978 N. 48, Z 9 .

New York City-Politics, ii vols., pamphlets, Columbia University Library no. 978 N. $48, \mathrm{Z}$ II.

Oberholtzer, Ellis Paxson, Jay Cooke, Financier of the Civil War. Philadelphia, I907.

O'Conor, Charles, Address of, The Constitution. New York, 1877.

Paine, Albert Bigelow, Thomas Nast-his period and his pictures. New York, Igo4.

Parton, James, Famous Americans. Boston, 1867.

Parton, James, How New York City is Gozencd. Boston, I866.

Parton, James, Men of Progress, ii vols. Cincinnati, I870-7I.

Perry, Thomas Sergeant, The Life and Letters of Francis Lieber. Boston, I882.

Pierce, Edward L., Memoir and Lettcrs of Charles Sumner, iv vols. Boston, I893.

Porter, George H., Ohio Politics during the Civil War Period. New York, I9II.

Republican Party. Official Proccedings of the National Convention of the, 1868. Chicago, 1868.

Rhodes, James Ford, History of the United States, $1850-1877$, vii vols. New York, 1896. 
Schurz, Carl, The Reminiscences of, iii vols. New York, r9o8.

Scott, James Brown, Cases on International Law. St. Paul, Minn., I906.

Seward, William H., The Works of William H. Servard, v vols., edited by George E. Baker: Ist 3 vols., New York, 1853; vols. 4 and 5, Boston, I884; vol. 5, The Diplomatic History of the War for the Union.

Seward, William H., An Autobiography, iii vols., edited by Frederick W. Seward. New York, I\&gi.

Sherman Letters, The, edited by Rachel Sherman Thorndike. New York, I894.

Sherman, John, Recollections of forty years in the House, Scnate and Cabinct. An Autobiography, ii vols. New York, I\&95.

Smith, Matthew Hale, Sunshine and Shadow in New York. Hartford, Conn., I883.

Stanton, Elizabeth Cady, Reminiscences of Eighty Years and More. London, I898.

Stanwood, Edward, A History of Presidential Elections. Boston, I892, 3rd ed.

Stead, W. T., Satan's invisible world displayed: or, Despairing democracy; a study of Greater New York. London, 1897.

Stevenson, Adlai E., Something of Men I have known. Chicago, Ill., 1909.

Storey, Moorfield, Charles Sumner. Boston, I901.

Sumner, Charles, The Works of Charles Sumner, xv vols. Boston, I87o.

Sweeny, P. B. On the ring frands and other public questions; taken from his intervicus and other papers. New York, I894.

Swinton, William, How the Ring ran Pacific mail: a story of Wall Street. New York, I867.

Tarbell, Ida M., The History of the Standard Oil Company, ii vols. New York, 1904.

Townsend, John O., New York in Bondage. New York, I9or.

Vanderbilt, Life of Cornelius, Appleton's Cyclopedia of American Biography, vii vols. New York, 1889.

Wecd, Thurlow, Autobiography of, edited by his daughter Harriet A. Weed. Boston, I8S4.

Wecd, Thurlow, The Life of, edited by his grandson Thurlow Weed Barnes. Boston, I884.

Weed, Thurlow, What I know about Horace Grecley's secession, war and diplomatic record, a letter written in 1870 to Thomas C. Acton, New York, I872, No. Io of a vol. of pamphlets. Columbia University Library no. 329.01, $\mathrm{N} 2 \mathrm{~d}$.

Welles, Gideon, The Diary of Gidcon Welles, iii vols. Boston, I9II. 
Westlake, John, International Law, ii vols. Cambridge, (Eng.) 1904.

Wharton, Francis, 4 Digest of The International Law of the United States, iii vols. Washington, I886.

Williams, Talcott, Tammany Hall, (In Historic New York, I899). New York, I899.

Wilson, Henry, History of Reconstruction. Hartford, I868.

Woodburn, James Albert, American Politics. New York, 1903. 



\section{INDEX}

Abbe, Josinua G., 93, 166, 307, 356

Adams, Charles H., elector. 355

Alberger. Franklin A., of Erie, 41

All $\bullet n$, judge of Court of Appeals, $2: 24$

Allen, Augustus F., 244, note

Allen, Benjamin, friend of Conkling's, $386^{\circ}$

Alien, Cornelius L., suggestion time limit for Governor's signatmre. 2t'

Allen, Norman, 353, note; elector, 3.55

Allen, William F., elected, 208, 323

Allis. Auguntus ( $\dot{x}$. S., on committee to investigate Glenn's charges, : 86 , 287

Alvord. Thomas G., of Onondaga. 44; 93; candidate for Senator, 147 ; delegate to constitutional convention, 213; learl of $\mathrm{N}$. Y. delegation at Chicago, $: 10$

Anderson, Geol'ge B.. 307

Andrews. ( harles, delegate to constitutional convention, $2: 3$; member judiciary committee, 215; judre of Court of Apjeals, 2:4; delegate at large, 306

Andrews. Rufus. urges renomination of Alvord, 9:3; supports organization, 164; hand: np list of contestants, 303: and Van liuren reply to Spencer, 305 ; at Chicago, 310

Anti-rent aritation revised, 1866; influence on campaign; disturbunces in Lerne; comment of Times 12:

Anthony. Sisan B. Woman's Sufflage. :3:37. note

Arous (Albany), terms Barlow's nomination an insult to Democrats, 5 ; tells (xreeley he lacks the comrage to make a leater, 61 ; opinion of Fenton, 9.; defends IIsfinisn against Greeley, 12:; sums up work

425] of constitutional concention, 257 , note; rejoices orer Dem. Nat Con., 319; says (iriswold was nominated by Fentonites, 359; attacks (iriswold, 575 ; on Seynomr and Blair, 382

Armstrong, Comelius IV., of Albany, 53

Armstrong, John, 32:

A rnot, Sitellen S.. 179, 364, 368

Asell, David II. . 107

Asiman, IV. F. : 807

Astor, Juhn Jacob, War Dem. Cooper Union. 1868.:283

Astor. William B., War Den., Cooper Union, 1868, 383

Acerill, WV. J.. 53, 107: nominated for Gov., $363 ; 364 ; 364$

Baker, amendment to judiciary article, 216

Baker, A. D., 207

Balcom. Ransom, candidate for Senator, 147; Supreme Court, Bingliamlou, 274

Barker, (ieorge B., delegate to constitutional convention, 215 ; nember julliciary committee, $215 ; 307$

Barker, John 15.368

Barkley, Alexabiler, 307; nominater camal commissioner, $354-5$; vote for eamal commissioner. 186, ast arlow, Gen. Francis C., of New York, 5:; nominated for secretary of state 57 ; conduct during war assailed. 69; praised for bravery at Antielam, 70 ; shows lack of ill-will, 9t: 13i; allacks on Canal Ring, lifi; nominated secretary of state, $16 i ;$

Rarmard, Daniel P., delegate to constitutional eonvention, 213 ; reads letter from son. Murpliy, 312; 36.) 
Barmard, George (i., grants injunction agaims Erie. 272: suppends Drew, 273; enjoins Erie directors. 274; injunction, $275 ; 277$; exercines prerogntiven to lie end. 278; impugned. $279 ; 28.5 ; 2.7$; natualization record of, 348

Barnes, ('ongressman (Dem.), 196

Barnum, (ien. Henry II., of Onomdaga, 53; nominated inspector of prifoms, 57; citizens of syractuse suhmit charges against. $70^{\circ}$; testimony of Duane S. Hnud, 70 ; nominated State prisons inspertor. 355 ; vote for state prison inspector, 1808 , $59^{\circ} 2$

Barrett, Jurge, turns Gould over to special ofticer. 2sin; angry, 286

Tarto. Henry 1). . 5:;

Iiarto. Hemry 1). Jr., 107

Bascom. ()liver, nominated canal commissimer. 567 ; vole for canal commissioner, 1868,392

Bass, 'T. K.. 307

Batchellar. George S., elector, 35.5

Beach, Allen ( $.323 ; 324$; asplires to lient.governor-hip, 301 ; nominated for Gor., 3t 3 ; somuluation manimous for, stit: 370 ; vote for lieut. governor, 1868,392

Beach, Elias, 167

Berch, (ieol're. 823

Becker. (ieorge. Bil

Beckwith offers amendment, 217

Beecher, Henry Ward, letter to Soldiers' and Sitilors' Convention: prescience in treatment of negro prublem, 119, note; Greeley olposes; comment of limes; makes ratification speech for Radicals. I20; October results substantiate predictions of, 380

Peebe, Hiram, 324

Belden, Fisk's jartner, 277

Bell, James A., $9: 3$

Bell, Joln, popular vote, 1860, 392

Belmont. Au nst, cliamman Dem. Nat. Ex. Com.. 334; lapld firm for Jem. ticket. 1S68, 38:; isstes Dem. State ('ommittee's address, 384

Bemis. Ilorace, elector :355

Bemis. Matt P.. Times accuses, 188; Commercial Advertiser queries, 18!

Bennett. James (iordon. charges Hoffman with compt patronage, 116 ; reminds mblic of his prophecy, 135; Grant stronger than farty, 317 ; favors Chase. 327 ; ste olso iserald Benton. Anditor. World takes up admissions of 199

Bicklord, Marcu-, 245, note

Bigelow, Juhn, 373. note

Bigler, Gov., escorts Seymour to chair. $3: 57$

Bill of Rights receives modifications, $23 \mathrm{~s}$

Iilackley. Ehenezer, :07

Lilade (Toledo). opinion of Chase, $\therefore 66$

Blair. Francis P. letter to Broadhead, $3: 1$; $3.3: 3$; name for vice-ples. 341 ; \%78; wflers to resign, $3 \mathrm{Al}$; attacks continue against, 353 ; invades kant, 344

Blair. Montomery, follows Seward's footsteps, 73; speaker at Iem. rally, 20.5

Blakesley, L, $35 \mathrm{t}$

Blank nominates Woodford. 354

Blins, Archibalal M. . 307; testifies before Cong. com., 398

Bliss. George, Jr., witness Hale committee. 249

Plood, lsaiah, 179, 26s

lionesdale, Peter S. . 307

Buole, Hancis 1. A., New York City health inspector. 34

Bostom, llartford \& Erie R. R., John S. Eldridge elected pres. of, 271

Bowen, Benjamin B., 07

Bowne. Norwond. 353, note

Bradford. William R.. witness senate committee on brie, 281

Bridley majorily report, 281

Blarly. James, chairman lem. rally, 205 ; accuses Justice Barnard, 279

Brady. John R., testifies befure Congress. com., 397

Brazee, Andrew $\mathrm{W} . .307$

Breckinridge. pofmlar vote 1860,392

Brennan, Matthew T.. refuses renonination; Citizens' Association assails; Fenton appoints commission to investigate, $1+1$

Brewers, hop-growers and liquor dealers hold convention. 198; Arthur Brown. pres.: Riclard Katzenmeyer. sec., 194

Brigg:, (iporge, 107

Bristol, Wheeler H., nominated for 
treasurer, 179; elected. 208: introduced bill forbidaling consolidation of Vanderbilt and Erie systems, $28 t$

Broadhead, James 0,331

Broderick. Clarles W., 307

brouks. Erastus. morex for final vote on tenure, $2: 22$; profoses important ansulment, 244; 245 , note; charman state charities eom., $247 ; 323 ;$ 335

Brouks, James, defeats MIrs. Elizabeth Cady Stantom, 13i;

Brown. Arthur, president brewers' concention, 19t

Brown, D. D). S., connection with Gomld. 299: delegate at large, 806

Brown, E. A., proposes trial by jury, 231

Brown, John W., of Orange, 53

Brown, Levi H., nominates Allen C. Beach. $36 \%$

Brown, l,ewis 11., 107

Brown, Martin B., 93, 166

Brown, 11 illiam $\mathrm{C}$., jruposes court of nine, 218; elector, 35.)

Brush, Angrustus A., assemblyman, 27 ; Glenn saw guilt in his eye, 288; denies knowledge of bribery, 291

Butlalo, Bradford \& Yitsburgh R. R. lease to Erie, 270

Burlett, Luther J. . 323

Burke, John K., declines nomination for state prisons inspector, $\vdots 68$

Burrows, R. L., nominates Noalı Davis, l.jl

Butler, Benjamin F. false statements relative to (iriswold, 375

Button, Janes R., on committee to investigate Glenn's charges, 286

Button, Jonas, 324

Cagger, Peter, 53; calls Albany convention to order, $99 ; 108 ; 174$; resolution in memory of, $: 68$

Caldwell, Luther, 167; secretary const. conv. 2.14; witness IInle committee, 249 ; paid by botl sirles, 300 ; aprears before Hale committee, $301 ; 007-8$

Cameron, Delos IV., 307

Camprign of 1565 , minor personal is-ues, fiz; series of petty party quarels, 74

Camplell, Daniel D., elector, 367
Cardozo, Albert, candidate for Supreme Court on 5 tickets, 197; 323 ; $34 ;$ maturalization pecord of, 398

Carpenter, 13. Plaıt, 307

(arter, Enoch, 32:3

Carvell, Charles E., 53

(aryl. Lorenzo, 323

lassilly, Willinm, editor Albany Argus; consiolers Unimist resolutions narrow, 6f; and Schmmaker present minority suflage repurt, 231; 32:3; 32t; :65s; see also Argus

('nimberlain, (i) n., Governor of Maine, li:2. 377

Champlain, Marball B., nominated attorney-general, 179; elected. 20s; and Messrs. 'Tappan and Schoonmaker present minority report, $243-4$; acts for landerbilt, 272 ; pres. Den. Conrention, 322; $32 t$

Champion. Simon B., elector, 367

Chandler. 136;

Chapman, (J) W., senate committee on Erie, 280; at Sracuse, 3.j1

Chapman. (. H. . 35:

Chase. Silmon P.. Radical's farorite candidate, 215 ; Rej. elitorial favorite, 32i-7; Dem. disgnst with, 327 ; presidential candidate. 330 ; 333 ; lardly finnres in balloting, 34]: Sermonr favors, :34: more in favor of, 344; 346 ; thanked, 366 ; 37.; again talked of for l'residency, 35:; Herald elings t1. 403

Chatielil, Thumas J., 307

Cheseboro, Henry O.. eounty court sugrestion adopted, 22.1; temporary chairman, :b61

Chicago Convention, National Rep. nominating convenes $\mathrm{May}: 0$, 18 (is; new isslles. 309\% six candidates for Viee-president, 310: Grant nominated for Pres., :12; strife over Vice-presidency, 312; platform, 313; table of vote on Vice-pres., $: 13$, mote; comments of up-state press, 318

Chromicle (Penn Yan), leads liep. revolt, 202

Chrich, Judge of Conrt of Apreals, $2: 4$

Charch. Sandford E., favors was, 25 , 90: elected temporary chaiman of $1860^{\circ}$ Democratic (onvention, 99; made permanent president Albany 
(Dem.) Convention; 105: partnership with Davis, 14 ti; delegate to constitutional convention, 213; delegate at large, 323: prominent in N. Y. C'

Chureh. Col. Walter S., agent of Van Remselater's 12:5

Churchill. Congressman (Rad.), 137

Citizens Conmittee of New York institutes reform of sanitary conditions in 1815,31

Civil Riglats Iiill, Congress passes over President's veto, April 6, 1666, 81

Clark, Inarius, 179

Clark, Egbert A.. elector, 367

Clark. George, 307

Clevelund. Grover, member com. on resolutions. 362

Clews, Henry, War Dem., Cooper Union, 1818, 383

Cobh, Timothy D., elector, 267

Cochran. Robert 323

Cochrane. John, principal speaker, 131; present at Cooper Union rally, 1:0; 007 ; at Syracuse, 351; Pres. Rep. Con., 353

Colby, Jolnn B. elector, 367

Cole, Asabel N., witness Hale committee, 299 ; testimony on Caldwell, 300; moves admission of Radicals. $3(15)$

Colfax. Schuyler, named for vice-pres., 310 ; 31\%; nominated Vice-President. 313 ; career, 315 . note; 356 ; candidate for speaker, $37 t$

Commercial Advertiser. condenns Remublican convention, 167 ; cantions approval of convention, $1=0$; pars attention to Rep. State C'on., 3.58; warns Repuhlicans against Tiibune. 372 ; places blame for election fratuls, 400

Comstock. (ieorge F., powerfinl campaign factor. 131; 179; delegate to const itutional consention, 213; member judiciary committee. 215; proposes court if seven, 218: moves to strike ont Brown substitute, 231; oljects to veto change. 213 ; refuses to rommit himelf 28

Comstock, ILarlow L., candidate for momination. $10 \bar{z}$

Conkling. Fresterick A., 359: nominated for Mayor, 40t; defeated. \$0.
Conkling, Roscoe, represents New York in 39th Cong., 45; tours State; strikes kernote, 127; extract from speech, footnote $128 ; 131 ; 137$; life, 145-1;; press of State pushes candidacy, 149; elected Senator on 5 tl ballit. 152; letter to wife; rise metenric. 154; World's opinion of, 156 ; character of, 157 , note; maiden speech. 158; position in New York political life, 15s; president of convention, 159; takes chair, 165; example of invective, 165 , note; at Utica, 1868, 3i 8; voted for $\mathrm{Ni}$ agara ship ramal. 369 ; frauds well known to. 394; 407; promoted. 410; in control of Republican machine in State. 413

Conklin. S. H., 9:3

Conger. A. B., presents platform. 324

Connolly, Mlichael, candidate for office, 142

Connolly, Richard R., Dem. nominee for city comptroller; elected, 142 ; $321 ;: 60$

Constitution. submission of. opinion of C. Z. Lincoln, 254 ; submitted in 4 parts, 2it; right of legislature in matter, 25ñ: voted on November:2, 1869: julliciary article apuroved; constitution rejecled, 256 ; center of

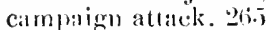

Comstitutional Convention. amendments subuittel, 212, note; new plan of representation, 212: delegates to. 213: William Wheeler chosen mresident. Luther Caldwell secretary, 214; judiciary article unsatisfactory, 214; conservativa of, 23!); two canal (ommittees appointed: financial provisions little changed; proposal for superintendent of public works, 24:3; finance article. many amendments proposed and rejected, 24t: eflucational, :-45; committee on official corruption, 246: Erastus Brooks lieads State charities committee, 247; discussion of adjommment. 27 ; submission in two parts recommended. 248. Folger summarizes work uf. 248-5:3 constitution signed: adjumment, 253; political aspect of, 256: Republican majurity; Sanford E. Chureh Dem. leader, 257; press comments, 264 ; 
see also Judiciary, Snffrage, Bill of Riglits. Legislature, Fixecutive

Cooper, I harles H. , 307

Coover, J. B., 356

Cooper, Peter, present at Cooper Union rally, 140 ; War. Dem. Cooper Union, 18i 8,353

Copperheads, activity in connection witl draft riots, $25-26$

Cornell. Alumzir B.. 93, 167; runs for treasurer, 167: named for lient.gov., 3.j4; rote for lieut.-gorernor, $18(i s, 34) 2$

Comell, Charles G., 108; corruption of. 116;179;323; 368

Cornell. Ezral, withdraws in faror of Governor Ferton, 12, 15!, note

Comell, 'Thomas, Congressman (Rad.), 137 ; elector. 3.55

Costello, l'atrick (., elector, 355

Courier (Charleston, S. C.), expresses disgurt, 20j

Cox, Sanuel S., speaker at Dem rally, 20,; 335

Craig. James B., 323 ; report of committee on resolutions, $366^{\circ}$

Crane, II. M. , 356;

Creaner, 'Ihomas J., senator. Vanderbilt supuorter. 286

Cross, Janes M., witness senate committee on Erie. 280

Crowley, Rirhard, at Clicago, 310

Culver, E. D., :307

Culver, James WV., 307

Curtin, Gov., named for Vice-Pres. $310 ; 317$

Curtis, George William, editor Putmamis Mragazine and Harper's Weekly, life, 147; withlraws nane. 148; delegate to constitutional conrention, 213; champions wonan suflirge, 2:7; proposes adjourmment, 247: elector, 355; see also Iiurper's Weekly

Curtiss, F. D., 167

Cusburan. Don Alonza, Republican alderman, 143

Daily Courier (Buffalo), lauds resolutions of Albany Convention, 54; argues for the Radicals. 6l; opinion of Fenton, Alvord and Bruce. 94

Daily Comrier and Union (Syracuse). explains Greeley's metlinds, 79; attitude on eoup d' état, 109; lsos- tility to Weed, 130; annoys Albany Erening Journal. 203

Daily Dimocrat (Rochenter), defends Sen. llumplirey and J. M. Hammand, "20:3 on Chicago Convention, $\therefore 18$

Dar y Junrnal (Ogdensburg) questions sincerity of Democrats, 7i); recognizes "will of the people," 94 ; satistied with IIulburd's nomination, 170

Darly Jounal (Srracuse), rejoices over pasing of Albany Regency. 10.); blames Howace Gireeley for liep. defeit. 200)

Daily (Hberver (Utica), consoles the Unionist comvention, 61; typical I) en. opinions. 320-1

Daly Republican (Binghamton), classes itmelt" as " adranced," 319

Darly Standard (Srracuse) attacks Slocnum, 22 : praises Alvord 94

Daily Union and Adrertiser (Rochester). attributes Ilemucratic defeat to lack of organization, 79 ; sees " hing" victory, 171

Daly, C'harles P., nember judiciary conmittee. 215; gives hintorical résumé, 217-18; testifies before Cong. com. , 397

Dana, Charles A., 345; see also Sun

Danforth, George F.. judge of court of appeals, 1878, 224

Dantrin, Isaac, 93

I avis, Eneron E., $32 \%$

Davis. J (: Bancroft, Erie directory, $2 \& 0$; gives leading evidence, 28i; fined. $2 ! 17 ; 25.52$

Davis. Noah, life, 146; olds in favor of, 48 ; in lead on list bullot, 152

Dayoun. Lewis $P$.. on commintee to investigate Glenn's charges, 286

Decker, James D, 323

De La Matrr, Gilbert, nominated State prison inspector, 166; defeated, :0s

Delaran. E. (., letter from Homer A. Nislson. 206

Denter, George W., nominates GrisHold. 354; elector, 355

Dening, Colonel, Cooper Union, 1868, $37 !$

Democrats, retain strengtl in State througl, forejgn element: 25 ; evidence of strength. 26; control in 
1868, 26; chief source of power in Tammany's hold over balser elements, 35: State Convention charges Depew with fraud, 42; New York State ticket for ls64, 44; Albany Convention of 1845 develops change of policy, $4 \mathrm{~s}$; praines palty's history, 50; platform, 50; Union jonrnals accuse party of dodging issiles, 5]; N. Y. State ticket for 18 $4.5,53$; Ogdensburg Duily Journal comments on resolutions, 54; all Democrat papers excrept Neus endorse platform and candidater. 5.5; classed as IVar Demucrats and Copperlueads, 89; Convention of 1866 opens in Tweedle Hall Alhamy. Sept. 11, (1); called to order by Peter (agger, 9! ; rival delegations pacified, 100; candidates, 100 ; deternination to mominate Hoffiman. 101; eoup d'étut of Simford Church, 102; editorial comments on errup d' étut, 108; new Siate comm ittee. 107 ; platform, 10?110; ediorial comments on platform, 111-14; win in New York, 1866; reason for strength. 134: senatorial ancus, 153: State Convention 1xtit attendance small. 171; opinion of Horld, 172; Seymour rules, 17t; platform, 177 ; nominations, 178; ticket, 179 ; reactim in fayor of. 182; comnt on public disatisfaction, 18ti; Pennelvania, Ohio. Iowa, give maj. to, 1sti; editorial comments on maj. . 187; Sun and World warn. 191; mafication meeting, I!)! hold last rally at Cooper Union; J. T. Brady, C. S. Thayer, Voorhees, M. Bair and S. S. Cox chief speakers, 20.5; win 1867 elections, 207; resulis, 208, note; comments of press. 200-10: State Convention of 1nt8 opens Mareh 11, at Tweelle Hall, Albany, :221; platform, 324; State mominating con. 18ti8. meets at Tweedle Hall, Alhany, $3 t 0$; rontest for seits. 3 ril; State ormmittee enlarged. 362 ; platform, 3 ti6; electoral ticket, 367 : press comments on com. . 369-70; central committe sends secret cirenlar. 313 ; National Nominating Convention of 1868 , see New Iork Comrention

Dewson, C: M. , 352
Depew, Channcey M., secretary of state, makes censis rejort, 41 ; Democraticstate Convention charges framd, 4\%; permament president of Unionist Convention. 5ti; declines to lave name considered, 57; facts about declination. 60: tendered nomination by both factions, 61 ; reports conversuion wilh Vau Buren, 68; 159; present at Cooper Union rally, $190 ; .07-8$; at Svracuse, $331 ; 33 \%$ nominates Greeley in 1868, 35t; at syacuse, 1848.386

Dewey. William. 807

Dewrif, Delos, 107; delegate at large, $3: 3 ;$ elector-at-larue. 307

Diven, Alexander S. breaks Sabbath, $27 t ;$ vice-president of Erie, $2 s 0$; fined, 297 ; witness Hale committee, 299

Dix, John A., hailed by some as future leader, 69 ; cliosen temporary chairman National Union Convention, 82; 90 ; candidate for Governor, 100; name hissed, 104; aided by Ritymond, 104; :38; 408; 409

Donglis, Stephen A., popular vote, $1860,39.2$

Dodge, Creneral (Iowa), throws delegation to Colfax, $31: 3$

Doolitule. James l:.. president of $\mathrm{Na}$ tional Union Convention. 82

Dorn, Rubert ( $i$. of of Schenectady, 53

Dowling. Juseph, 323; elector., 367

Drew, Daniel, career of; comparison with Vanderbilt, 268; loans Erie, $\$ 3.480000$, upon security, 2 ig; transforms Etie convertible bonds, 270; Vinderbilt seeks removal of, 273; surpended, injunctions of no effect, 273; surprises Vanderbilt, 274 ; breaks Vanderbilt corner, 27.5 ; 276 ; victory, 277; situation very faroralile to. 277; testimony, 281 , 28.; slips into N. Y. C.. 2.14; share in settlement. 2\%; not pmished, 297: wituess IIale committee, testimony. 2499

Drver. IVillian C., elector, 367

D)iell. R. IIullaml, 307

Dutcher, S. B. . 356

Dwight, Jeremiah W., 207

Dwiglit. Theodore IV. . lelegate to constitutional conrention. 213; member judiciary committee, $215 ; 353$, note 
Earl. Rohert, Judge of Court of Appeals, 221 ; pres. 1568 Dem. con , 362

Eastman. H., ltiti

Eaton. Dorman B., candirlate for corporation comsel, 40.5

Editorial comment, 371

Elwards, Lewis A. elector, 367

Edwards. William G. witness senate committee on Erie 280

Eldridge, John s., pres. Erie R. R., 271 ; fails to appear as witness, 281 ; appointment with Gould, 29.5; Bostol interests, 296; fined, 297 ; personal account. $2 ! 9$

Elections for State officers in other Stites, 20i

Endres, Isaac L., 93, 167. 307

English, (rovernor, spoken of for Bhair's place on ricket, 382

Ericsson. insentor of Monitor. 374

Erie Raiload, relation with State politic; expenses of, 2:7; borrows from 1)rew, 269 ; Drew's roup greatest W'all street sucress, 270 ; hostilities reopened by Vauderbilt; injunction, 272

Esseltyne, Cornelins. 356

Esterlironk. W. P., 3.56

Erarts, William VI. present at Cooper Uniom rally, 190; delegate to constitutional convention, $-1: 3 ;$ member judiciary committee, 215; defends maljority report, 219.22 ; remarks effect of growth of New York City on probale cases, 230 ; oljects to veto change, 243

Evening Journal (Albany), states six puints settled by 1865 elections, 78 ; attacks Johnson, 97; murestrained enthilsia $-m$ of, $3: 0$; sums up issues. $18.18,388$

Evening Post, complacent, 55; gives reasons for inactivity of campaign, 65; advice to southerners. fitj; Chicage platform not so broad as desired by, 316: adrocales Chase. 32.5 ; opinion of Blair. $3 \cdot 7$; reassured at to currency, 37t; attarks Hoftman for connection with Tiveed. 377; denounces election framis, 401

Ewing. Thomas (General', spoken of for Blair's place on tirket. 282

Excise Law passed. April 14, 1866; enforcement helps Fenton, 1:3; Tribune repudiates Radical resolu- tion, 185; Harner's Weekly summarizes report of Police Buard, 185; Tribune fosters movement; mass meeting at Cooper Union, 204; chief interest in campaign. 209

Executive. three committees report, 211 ; Fenton's suggestions, 211-2; ratical change in veto power suggerted. 243; existing veto power retained. 243

Express (Buffilo), comments on Democratic Convention of 1865.54 ; reverts to infancy, 65; expresses contempt, 1s:; sincere endorsewent of Colfax, 218

Fargo, William G., 108; 179; elector, 367

Fairman, Charles G., 93

Farragut, Admiral, refuses nomination. 380

Farrington, Fzra, 93

Fanlkner, Lestel B. . 324

Fay, John D. nominated canal comminsioner, 179: elected. :0s

Fenian agitation, origin. footnote: fills papers: Tribune endeavors to inflisence vote, 12l; attitude of President, 122

Fenton, Renben E., Gorernor by less than ! 1000 in 18644,26 ; rise backed hy radical faction, hreaksweed's power, $2 \overline{7}$; attempts to allay unrest over decrease in canal revenue. 39: of ('luntanqua, 44; calses downfall of Seymour, 44; receives 369.557 votes for Gov., 45; 92: elected orer IHoffunan, 133; attitude in senatorial campaign. 149; friends of Alvord and Bruce wish revenge on. 150; Conkling scores point on, 159; lat stand of Vanderbilt in executive chamher, 2ati: opposition to candidacy of, 306 ; named for vice-presidency, 308 , : 10 ; :112; third for Vice-pres, :113, 317: 053 ; 356 ; 407 ; trusled. maladministration, 410; 411 ; administration womld not be tulerated today, 41\%; goes to Senate but his State machine broken. 41.

Fordon, ex-Senator, of Rorkland, 161

Ferris, (ingressmin (Rad.), 16th dist . 1:37

Ferry (Cimst. Convent.. 1867), proposes amendment to judiciary article, 216 
Field, Benjamin, 208; at Syracuse. 3.jl Franklin, Morris, letter from, 102

Fielu, David Dudley, Gould's coun- Frear, Alexander. on committee to sel, 284

Field*, Congressman (Rad.), 19th dist., $1 \because 7$

Fields, Thomas C., Greeley's informant, $2: 19$

Finch. Francis M., judge of Court of Appeals, 2:4

Fish, Henry If. . 107

Fisher. Johin, 307

Fisk, James, Jr.. career of, 271-2; seizes bunds. 27t; 241; predicts furlher trouble. 29.5: receives with Gould the Erie. 296; not pmnished, 297; witness Hale committee, 299

Fithian. Freeman J. joint director with T. Murphy, of reorganization committee. 301

Flinger, 'Thomas $\mathrm{T}$., delegate to constitutional convention, 213

Flanders, Francis D)., elector, 367

Flopd-Jones. Darid R of (zneens. 44; contest with Nelson over secretary of stateship, 17y

Folger, Charles J., temporary chairman of Unionist convention, $56 ; 54$; Rep. candidate for Senator, 145; withdraws name. 148; mentioned to succeed Martindale, 16il: delegate to constitutional comvention, 213; member jndiciary committee, 215: judge of Const of Appeals. 224; 231 : ofjeets to reto change, 243 ; summarizes work of constitutional convention. 248; at Chicago convention, 310

Follett, D. L., 107

Forrest, David P... of Schenectady, 44

Forrest. Nathan B., 380

Fort. B. G , 356

Fort Taylor. headquarters of the Erie exiles. 278

Fourteentls Amendment. has inception in report by Stevens, 82

Fowler. John S. . 307

Fowler. W. A., 179, 368

Fox, George L., elector. 367

Fox, John. defeats Greeley, 136

Francis. Jolun M.. delegate to constitutional convention, $21 \%$

Francis. Thayer. editor Troy Times; at Syracnse, 3.51

Frank, August, named for lieut. -gor.. 354 investigute (ilem's charges, -6 ; demands investigation, $2 \backsim \bar{\tau}$; talks with Glenn. 288; testimony. 2s!; unacquainted with Lewis, 200 ; request to be dismissed from conmittee denied, : 91

Freednan's Bureau. Johnson vetoes bill to enlarge powers of. $\& 1$

Fremont. J. ( $($ (General). State ratification meeting, $1864,37$.

Frost, Calvin, presents resolution in memory of Peter Cagger, $3 t, 3$

Furro, Joshua, Jr., State committee, 3.56

Gale, Moses D., commended. 3:8

Gallagher, Frank B., nominated for inspector of State prisons, 10 -

(ranson. John, candidate for Court of Appealis, 179

Garritt, S. B., 167

(iarvin, Indge, 360

liates, Theodore B, proposed for State treasurer. 1122 ; noninated for treasurer, $166-7$; defeated. -05 ; reports on permanent organization. 1S $8,35.3$

Genet, Henry W., amends Senator Pierce's motion. 280

Gerry. Elbridge T.. delegate to constitutional conrention, 213

Gibbons, Abby Hopper, Woman's suffrage, 2:37, note

Gilbert, Judge, issues injunction restraining all parties to Erie litigagation, 277 ; passed ont of the fray, 278

Gillis, William, 307

Gleason, W. H., 93; admits irregularities. 1ti4

Glenn. Elijalı M. K., assemblyman, makes clarges, 286 ; names Frear as person who attempted to bribe lim, testimony ineffectire, 287 : story of the attempt to bribe him. 288: contradicts sworn statement of Frear and Lewis, 259; charges found to be unjusitited. 291

(ilowark. Henry J., 361

Godard, Charles W., Rep. State central com. .93; 161; at Syracuse, 351

Gondrich. Milo. presents minority report of juliciary committee, 215 ; minority report, 226 
Groodsell, J. Platt. cand. for state engineer, Union ticket, 5is; charges unearthed against, 7. ;

Goodvear. Charles, del. to Dem. Nat. con. . 323

(iould, Jay, prominent figure, 268; career of, $271 ; 276 ; 28 \mathrm{i}$; astonnded, 283: gues to ilbany, arrested. 28 !; goes to N. Y. with sheriff' O'Brien; returns to Albany with Oliver. 285; fails to report before Judge Barrett, $28(i$; reports on the size of his bribes, 292 ; appearances against. 242 ; unprovided for denources settlement. 295: receives the Erie. :97i; not punished, 297; methods, 2as: wilness Hale committee, testimony. 299;300 Gould, John Stanton, 24. note

Gialiam, James $1 \mathrm{H}$., elector. 3.5

Graham. Senator. has itching palnu. 301

Grant. Ulysses S., nominated for Pres. by John A. Logan, 312; nomination foregone conclusion, 314: :, 6 ; opinion of Herald on. 371; why people would vote for, 376 ; eleccoral rote. 1868, -92 ; Evening Post comments on election of, $402 ; 411$

Grares. Const. Convent. of 1868 , pror poses eourt of eight, 2 ls

Gray, judge of Court of Appeals, 224

Greeley. Hornce, rise of feud with Thurlow Weed, 24 ; 4 ; appears indifferent to nominations, 59: collides with Kaymond. 62; interpretation of Unionist victory, 77; leader Syracuse (Rep.) convention, 92: questions citizens, 115; opposes Beecher, 120 ; announces candidaey; defeated by Fox, 144. note; position in Senatorial race, 147-8; 159; erlitorial on silence, 150; warns New York Republicans, 187; present at Cooper Union rally, 1!0; delegate to coustitutional convention, 213; presents suffrage report, 233: suggests fifteen districts. 23: ; suggests no pay for senators. 241; impatient at irregular attendance. 259 ; lets out feelings by biting remarks in Tribune, 259-60, note; witness Hale committee, 298; testimony on Caldwell, 300 ; address to convention, 308 ; opinion of Chicago convention, 315 ; reviews Seymour's pact. 348; candidate for tiov., 35\%; represented by .j. R. Young, 351: named for crov. 354; attempt tw substitute for Roberts, 355; lauds Griswold. 357; 359; thinks Seymour's case houeless, 380 ; Republicans take advice of, $37 \%$ : directs attention to election frands, 3S4; replies to Hoftinan's proclamation, 385; condols with Seymour, 402; 417; disgust with, 410; still a power in party, 413; see also Tribune

Greeley. Mrs. Horace, woman's suffrage. $: 3: 37$, note

Green, Andrew 11., chair. com. on per. organization bem. con. 1S6t, 104 ; declines mayoralty nomination, 404

Green, John A., Dem. State com., 1865. 53; declines nomination for secretary of state, 178; 174; delegite, 1818, 3:4; opposes Chase, 343; at Albany, : 0

Green, Johin (\%, nomiuates Gen. MeKean, 166; War Dem., Cooper Union. 1868. 34:3

(ireen. W. W., editor of the Syracuse Daily Courier and Union. 34!-50

(irinnell. Noses 11., delegate, :07; elector, 355

Griswold. John A., represents N. Y. in 39th Cong., 45; 137; candidate for Gov., 351; nominated for Gov.. 354; 'Times points ont experience of. 3.77; connection with Monitor, 374. 376; for liquor men, said Herald, 378; State ratification meeting. 379; at Syracuae. 1868, 386; voted for Niagara ship canal, 240 ; rote for Governor, 1848, 392; 411

Groesbeck, Darid. Drew's broker. 275; $276 ; 280$

Grover, Martin, nominated for Conrt of Appeals. 53; 179; electerl. 208

(intlirie, H. H. . elector, 355

Hackett. John K.. elected recorder. 135

Hale, Matthew, nember judiciary committee, 21.5: amendment rejected. 2.2 ; proposes Suprense Court of 12 judges, 2.27 ; against separate submission, $25 \mathrm{~S}$ evidence of his committee does not bear out charge that Fenton's signature was bought. 
294; senate commitee to investigate legislative corruption, 298; at Syracuse, 351 ; $35 \%$; refuses to serve, 353

Hall, A. Oakey, nominates Hoffman for Governor, 105 ; convention speech, 175; candidate for district attorney, 197; 323; 324; seconds Hoffuan's nomination, 363; 399; nominated for mayor, 404 ; elected. 405 ; T'imes opinion of, 40.5

Hall, Newman, D. D., address Cooper Union meeting, 204

Halpine, Gen. Charles G., register, 135

Halstead, Daniel.J., editor of Sy racuse Daily Courier and Union explains chuice of Barlow, 58

Hawlin, Hannibal, named for vicepres., $310 ; 317$

Hammond, Gov. (S. C.), escorts Seymour to chair, 317

Hawmond, John, of Essex, 92; nominated canal commissioner, 166 ; accused of wrongdoing, 203; defeated, 205

Hampton, Wade, Radical, 380

Hancock, Winfield Scott, Presidential candidate, 330 ; refuses second place, 382

Hand, Augustus C., alternate, $32 \%$

Happen, use of word in Constitution. 118

Harcourt, James, contests seat with Marsh, 361

Hardenburgh, Jacob H., defeated by Bristol, 179; 323

Hardly, S. G., 93

Harper's Weekly, praises Slocum, 71; comments on Hoffman, 116; cartoons of Thomas Nast, 126, note; tribute to Conkling, 156; reviews Seymour's past, 174; underestimates Dem. strength, 181; takes up legislative corruption, 199. note; amuses itself with $A$ rgus, 257-8

Harris, Hamilton, 93; 166; witness committee, 299; chairman Rep. State central com., 303; Gould's counsel, 286; $307 .-8$; at Syracuse, 351 ; calls convention to order. 352 ; 356

Harris, Ira, campaign for successor, 144; life, 145; loses supporters, 148; delegate to constitutional convention, 213; offers substitute for minority report, 217
Hart, Emmanuel B., delegate, 323; elector, 367

Hart. Roswell, loses election to Lewis Selye, 130; 352: seconds Griswold's nomination, 3.54

Hasbrouck, Robert M., 307

Haskins, John B., publishes statement, 72; chairman committee on resolutions, 176

Haskins, James P., delegate, 324

Hastings, Hugh, at Chicago, 310

Havemeyer, William F., War Dem, Cooper Union, 1868, 383

Hawley, ex-Gov. (Conn.), permanent pres. Chicago convention, 311

Henderson. Samuel, describes treatment in Southern prisons, 127

Henderson. W. B., candidate for clerk of Court of Appeals, 361

Hendricks, Thomas A., Presidential candidate, $330 ; 343$

Herald, The, commends Denocracy on recovery of temper, 54 ; seconds Raymond's position, 66; admires Seymour's convention speech, 1734; attacks probity of legislature, 19S; criticizes convention, 261 ; contempit for Church, 338-9; admits Grant's election, 381

Herman, G. M., elected supervisor, 135

Hicks, Russell F., senator, testimony, $300 ; 301$

Hill, D. H., (Gen.), 380

Hillhouse, Thomas H., nominated for comptroller, 53; suggested for comptroller, 166; defeated, 208; 356

Hiscock, Frank, State Central Com., 1866, 93; delegate, $307-8$

Hoffman, John T., candidate for Governor, 100: nominated for Governor, 105; speech of acceptance, 106; opposed to legislative commissions, 115: Times accuses, 115; Copperhead affiliations reviewed by Tribune, 116; Harper's Weehly calls him "candidate of grog-shous "; attack of Independent, 124; tours State for Democrats; comments of Tribune; reply by Argus, 129; prominent at Dem. convention, 172; Spencer pledges support to. $304 ; 360$; Morrissey 's opposition aids. 861 ; nominated for Gov. 362; 370 ; opening speech, 1868,$376 ;$ strong in State, 384 ; 
issues proclamation, 385; at Roches- Jackson, Thomas WV., 353, note

ter, 387; vote for Governor, 1868, Jacobs, claims Voorhies place, 321, 392 ; carries State, $293 ; 405 ; 411$

Hogsdrats, Jacob W., 807

Holi. Horatio N., Rep. State Con., 1860,$93 ; 1867,166$

Hopkins, Charles H., Rep. State Com., 1866, 93; 1867, 167

Howell, Daniel C., delegate, $32+$

Howland, Joseph, of Dutchess, 5 :

Hoyle, T'imothy, delegate, 323

Hoyt, Stephen T., of Steuben, Rep. candidate for canal commissioner, $1860 ;, 9 \%$; resigns senate, 137 ; delegate, 307

Hubbard, John F., Congressman (Rad.) 17th dist., 137

Hulburd, Calvin 'T., candidate for Senator, 147; justified by Conkling. 158 ; nominated for comptroller, 166; declines nomination, 167 , note; $307-08$

Hull, H. H., Rep. State Com., 356

Humphrey, 1. M., receives presidency of Albany (Dem.) Convention, 48; Congressman (Dem.), 30th dist., $1866,137$.

Humphrey, Wolcott J., arrested for bribery, 197; senate committee on Erie, 280

Hunt, Ward, nominated for the Court of Appeals, 53

Hunt, Washington, Dem. elector-atlarge, 44

Hunter, Arthur W., 53

Hurd, Duane S., testifies to Barnum's unpopularity, 70

Husted, James W., 356

Hutchins, Waldo, Rep. State Com., $93 ; 166$; delegate to constitutional convention, 213; member judiciary committee, 215; at Syracuse, 351; $353 ; 356$

Ide, Augustus, 368

Ide, Erastus, 179

Independent, The, voices Radical battle-cry, 115; deserts Chase, 326; assails Dem. candidates, 348; predicts Republican victory, 372

Innes, George, elector, $35 \%$

Irving, James, assembly, 208

Jackson, James, Jr., Dem. State Com., $179 ; 368$ note

James, Henry R , editor Ogdensluurg Daily Journal, 54

Jane, Samnel, elector, 355

Jenkins, J. B.. Rep. State Com., 167

Johnson, Andrew, overtlirow prepared by Fenton's machine, 27 ; congress at cross purposes with, 45; Reconstruction policy substantially Lincoln's, 45-6; denunciatory declamation further alienates Cong., 47; majority of party conventions back policy, 48; Sumner, Stevens and Wade learn be is not to be moved, 61; Radical leaders beliere he favors immediate enfranclisement of the negroes, 152 ; recognized by Unionist convention as "statesman of ability," 63 ; retnes bill to enlarge powers of Freedman's Burean, 81; makes White flouse spech Feb. 22, 1866, 81; retoes Civil Rights Bill, 81; tours country, 87 ; at St. Louis accuses Unionists of planning New Orleans massacre, $s 7$; hurts National Union cause, 117; attitude on Fenian movement, 12:; comments of World and Universe, 122; scapegoat of Rep oratory, 132; policy denounced by Chicago convention, 313; candidate for renomination, 330 ; applauded, 366 ; talked of for Seymour's place, 382; enemies and supporters, 407; Democrats support, 408

Johnson, Reverdy, Presidential candidate, 330

Jones, Edward, delegate, 323 ; elector, 367

Jones, Fred H., delegate, 307

Jones, Patrick H., delegate, 307

Judiciary, dissatisfaction over, 214; Court of Appeals receives most serious attention, 215; composition of committee, 215. note; protracted debate begins, 216 ; tenure during good behavior rejected, 222 ; motion for re-election carries, 223 ; disposition of cases pending in Court of Appeals, 225; many proposals on Supreme Court, $225 ; 3$ departments suggested, 226; age limit and term fixed, 228; proposed changes for 
county courts, 229; term of county Lane, Director (Erie), tined, 247 court judges, $229-30$; jury trial provided for surrogates' conrts, $2: 1$; division or question of election or appointnent. $2: 2$

Jndson, Edward B., elector, 355

Judson. William R., elector, 367

Juliand, Frederick, Rep. State Con.. ist6, 93; candidate for treasnrer. 161 ; runs for treasurer, 167

Kelly, John, ealls for loan for Tammany Hall, 200 ; declines mayoralty nomination, 401

Kelly, Richard, Rep. nominee for city comptroller, 141

Kelly, William E. of Dutchess, 1 it

Kelsey. Congressman (Rad.). 137

Kennedy, John A., present at Cooper Union rally, 190

Kenney, W. H. M., 166

Kernan, Francis, conciliatory speech of, 10.5; 108; delegate to constitutional convention. 213; nember of judiciary committee, 215: 823 ; $324 ; 335$

Laming, Albert I.. 53; 108; sides with Nelson. 179: aspires to lieut.governorship, 361 : named for Gov. . $363: 364$

Lanning. Robert, alternate, 823

Lansing, Edward, representative Soldiers' Organization, 355

Lapham. Filbridge G., introduces motion, 235

Laphan, Gerome, 166

Lasher. James D. on committee to investigate Glenn's charges, 286

Law rence, Major-(ieneral. suggested to succeed Barlow: conduct at Fort Columbus, 161

Law rence, Darius $W ., 203$

Lawrence. E. A., nffers amendment on bond taxation, 176

Lawrence, Hudson, nominated for secretary ot state, 166

Law , George, alternate. 323

Lawson. John D., 307

Leavenworth. General, at Syracuse, ' $7 ., 159$

Lee, flarles H., 324

Kerr, M. C., and L. W. Ross present Minority Cong. report, $: 99$

Ketchum, J. H., 197; 16: abolish justice of sessions, 230 , note

Kilpatrick, General, Cooper Union, 1868,379

Kimball, J. W.. of Franklin, 188; at Syracuse. 351

King. A. H., 93

King, H. J., $16 i^{\circ}$

King. Preston, of Ogdensburg, 44; colleague and friend of Johnson, 59; made Collector of the Port of New York, 60; jumps from ferryboat, 60

King, Rufus H., 807

King, William, receives $\$ 2,000$ from Gould, 299

Kingsley, Lewis, 307

Kingsley, Nathan, head of Radical delegation, 305

Kinsley, L., 356

Knapp, Moore R, 179

Laffin, T. L., 53

Laflin, F. D., Dem. State Com., 186ti, $107 ; 137$

Landon, Judson S. . proposes abolition of Court of Appeals, 227

Legislature, large district plan proposed, ¿3!); Mr. Schoonmaker's plan, 239 ; inerease in number of assemblymen suggested: saliry fixed, $\therefore 40$

Lewis. Joseph L., 324

Lewis. Mark M.. lobbyist, $2 \diamond 7$; talks with (ilenn. 288; testimony. 289; interested in Watervliet health bill, 290

Lieber, Francis. letter from sumner, footnote, 59

Lincoln. Abraham, carries siate by less than 7000 in 1864, 26 ; majority in N. Y. slight, $45 ; 137 ; \mathrm{N}$. Y. majority in 18t0. 392; popular vote $1860,1864.542$

Lincoln. Charles Z. . comment on judiciary comnittee, 215; comment on Evarts address, 222; on powers of legislature, 254

Liquor traffic, its relation to politics, 35

Little, James D., 361

Livingston, E. V.. of Lewis, 167; $307 ; 356$

Locke, D. R., see also Nasby. P. V.. 117

Loew, Charles E., $323 ; 324$; elector. $: 367$ 
Logan, John A., nominates Grant, 312 MeMuray, William. 175

Loomis, Benjamin N., elector, 367

Lord, Jarvis, of Monroe. 4.4

Lounsberry, William, 361

Low, H. R., 307; 351;356

Loyal League, meets in syracnse, Sept. 5,1866 . foot note. 92

Luddington, urges Beach's seleetion, $36 \dot{t}$

Luke, Henry C., 356

Lyon, tharles L., 324

Lyon, John, $93 ; 166$

MeNeil, David B.. of Clinton, 44; nominated State prisons inspector. $36 \pi-8$; vote for State prison inspector, 1868. 392

Mc Nutt, Andrew J., of Allegany, is

McQuade, James, aspires to lient.governorslip. 361 ; eleetor. 367

Madden, Edward M., names Conkling president of eonvention, $159 ; 16 t i$ : letter from Van Wyck. 352; 353

Magone, Daniel, Jr., nominates W. J. Arerill, 363

McAlpine, William 'L., War Dem., Maine, Kep. majority in 186if; ClamConper Union, 1868, 383

Mccarthy. Dennis, Congressman (Rind.), 23rd dist., 137

Meclellan, (ien. George B. Lineoln's majority over, slight in N. Y., 4j; candidate for I'res., $\$ 30$; popular vote, 1864, 392

Meclosky, Felix, Albany, 1866. 103

MeClure, A. K., eharaeterizes Conkling, 157

McConihe, Isaac, 268

McCook, Gen., calls for use of Honse rules, Dem. Nat. Con., 335; op-

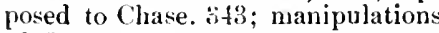
of, $31 \mathrm{~s}$

MeCool. candidate for register, 18fic, loses to Halpine, 135

MeCoombs, lsaac, Js., 179

NeCue, Alexander, 32.); corporation counsel, 365

MeCunn, John (Judge), testifies before Cong. eom. . 394

AcDonald, Angas, 24t, note

McDowell, John, 93

Mccinire, Jeremiah, : 24

McKean, John B., defeated, 20s; candidate for secretary of state, 161: nominated unanimusly for secretary of state. 166 ; state ratification meeting, 1868, 379

IC Keon, John, protests :Igainst Dem. platform, 17ti; organizes party, 196

McKinnes, William H., 93

Melean, George $W$, alternate, 323

McLean, James, elector. :iliz berlain elected. 132.

Marble, Manton, editor New York World. 72

Marsh. Isaac M., wins seat eontest with fialconrt, 361

Marshall, I). I). T., nominates F. $C$. Barlow, $166 ;$

Marshall, William, $: 323$

Martin, J. G., speaks at Dem. ratification meeting, 191

Martin, judge of Court of Appeals, $2 \cdot 4$

Marrin, Comgresmam (Kad.), 38th dist.. 137

Martindale. Gen. John Hi. of Mifonroe. $; 3 ;$ mominated attorney-general, 57

Mason, Charles, mominald for Court of Appeals, 166; defeated, 204

Masten, Joseph G.. nember judiciary committee. 215

Nattice, Manly B. , elector, :G:

Wlattoon, Abner (, appointed to senate conmmittee 10 investigatu. Erie, $280 ;$ for sale. 281 : testimony. 282: visits Jersey ('ity, 283; suggests need of Erie representative at Albany. 284: votes for Erie. 293; witness Hale committee, 299 : nothing definite discovered relative " eharges against. \$01

Nattoon, John H.. son of Senator Mattoon. 280; witness llale committee 299

McLean, Washington, proprietor (incinnati Enquiver; letter from Pendleton. 34ti; hurries to Washington, 281; was thouglist to luave inspired World to demand change in 1$)(\mathrm{em}$. ticket. 282

Memphis massacre, $12 t^{\circ}$

Merrili. William 1I., !3; 167

Merritt. Benjamin. (General) at Syracuse. $951 ; 356$

Merritt. Elwin A., 93 ; 1ii6; presents leport of com. (m legislative organization, $.269,2.56 t$ 
Merwin, offers amendment to jury section of lill of Rights, 238

Metropolitan Board of Excise $v$. John Harris et al., 123-4

Michigan Sonthern \& Northern Indiana $R$. R., agreement with Drew, 272, note

Miller. George W., delegate, 324; nominates Hoffinan, 362

Miller, Ira O. . Rad. State Con., 166; 356

Milliman, Natlaniel, candidate for canal commissioner, 367

Mills, Borden H., 307

Mississippi ('onvention, refuses to accede to President's suggestion tor a qualified suffrage, 48

Morgan, Edwin I., (Senator) no orator, 128; present at Cooper Union rally; makes chief address, 190

Morgan. General, of Ohio. 336;

Morning Herald (Utica), characterizes Syracuse Convention. 98; says $1866^{\circ}$ (I)em.) ticket is not to be despised, 109; emphasizes fairness of Conkling's election, 15\%; mouthpiece of Conkling, 170-1; outlook not roseate to. 319 ; comments on N. Y. Con., 349

Morris, Judge, attacks Tammany, 363-4

Morrissey, John, 136: 323; 324; votes for Chase, 343 ; leads Brooklyn delegation. 360 ; opposition to Hoff man, :361

Mozart Hall, dissensions in give Tammany opportunity to extend control, 26; made honorary guests, 175; relation to Fernando Wood, 196; candidates for charter election. $404-5$

Murphy, Henry C, candidate for Governor, 100; attended by tonghs, 101; retires in favor of Hoffiman, 101; elected over Hall in Dem. caucus, 153 ; speaks at Dem. ratitication meeting, 191; delegate to constitutional convention. 213; delegate at large, $323 ; 343$; career of, :360; withdraws name, $36 \%$; 364 ; futility of candidacy, 355 ; tribute of Commercial Advertiser and World. 368

Murpliy. .James, delegate, 823

Murpliy. Thomas J., head of Twentythird Street party, 160; joint director with F. J. Fithian of reorganization committee, 304; at Chicago, 310

Myers, Gustavus, on conditions in New York, 34

Nasby, Petroleum V., letter of, footnote, 76 ; Sunging round the cirkle, footnote, 117; letters of. 126

Nast, Thomas, eartoons of, footnote, 126

Nation, The, comments on laissez-faire attitude of New York, 30; comments on parade of discharged soldiers in New York City, 3I; suggests method of settlement between Greeley and Weed, 6s; characterizes the combatants, $68-9$; on discussion over happen. 118; points out incompetency and frand, 19.5; expresses disappointment witl work of convention, 261; places blane for lack of success, 263 ; comments on naturalization and voting frauds, 394-5

Nutional Intelligencer, demands change in ticket, 381

Naturalization frauds practiced, $894-5$; methods, 395, note; Congressional investigation into, 395; Congressional committee reports, 3.6 ; part played by courts. 397 ; testimony of julges, $397-8$

Nauman, cand. for coroner, 135

Negro suffrage, see Suffrage

Nelson, Homer A., 53; temporary chairman Saratoga convention, 90; contest with Floyd-Jones over secretary of stateship, 178; nominated secretary of state, 179 ; bids for temperance vote, 206; elected. 208; delegate to constitutional convention. 213: 360

Newman. George C., 356

New Orleans massacre, 126

Newton. Lyman M., 356

New York C'entral R. R., lauderbilt takes over allied lines. 270

New York (ity, cosmopolitan elements in, 80 ; tenement congestion, 30 ; position in 1865,30 ; war record of, 30 ; sinitary conditions bad; reform instituted by Citizens committee, 31: large numbers of discliarged soldiers aggravate congestion, $: 1$; death rate in 1863 greatest 
among large cities of world. :32: life in Fisher's Alley. 33; " Ring"' derelopment due to low status of lite, :3; illiteracy of inspectors and health wardens, 34 ; in grasp of Tweed King, 44; charter election held Dec. 4, 140; campaign dull, 141 ; charter elections, papers take little interest, 142; charter elections of 1565, 104; Hall and Conkling nominated for mayor, 404

New York Convention (1868), Chase appear's best candidate, 325; Presidential candidates, $3: 30$; other Pres. candidates, 331, note; delegates' attitude on leading candidates; Seywour disturbing element, 332 ; meets in new 'Tammany Wigwam, 3i34; Seymour, pres; report of com. on peimanent organization, 33t; platform, 339-40; comments of up-state press, $3+8$

New York State, changed situation after Civil War, :6; conditions in 186.5 show its strength and resources, $29 ;$ war record of, $29 ; \$ 43,270,337.47$ disbursed in bounties, 29-30; industrially strong, 35 ; depression in shipping, $35-36$; agriculture in flourishing condition throughont War, 3637 ; comptroller's report for 1865 , 37-39; canal receipts and disbursements, 38 ; condition of railroads in 1865,39 ; report of the superintendent of the banking department for 1865,40 ; change in banking system, 39-40; census for 1865,41 ; census declared frandulent, 42; in grasp of canal ring, 44; elections, party tickets for 1564 , footnote, 44 ; elections, tickets for 1865,53 ; elections, Unionists win in 1865 by 27,461 majority, 77 ; elections, ediitorial comments. 78-79; elections, Republican ticket, $9 \%$; elections, comments of press, 138-10; claim that large sums of money were used, 139; Senatorial campaign intense and interesting, 145 ; Senatorial election caucus assembles Jan. 10, 1866; ( $:$ F. Folger, chairman, 1.50; elections, 67 ; little interest displayed; excise question prominent, 198; elections, ' $i 7 ;$ multiplicity of political organizations, 196; elections of
67: State editors' opinions. 201; elections, I)emocratic landslide, 207; legislature, Unionist's control in 1865, 45; legislature, bribery charges, 197

Nichols, Asher P., senate committee to investigate legislative corruption, 298

North, Samuel, 179, 368

Norton, Michael, 323

Notte, Adolphe, 167

O'Brien, judge of Court of Appeals, 224

O'Brien, James, agreement as sheriff with Field, 28t; appoints 2000 deputies, 899

O'Gorman, Richard, Tammany nominee for corporation counsel. 405

Oliver, James A., special officer in char se of Gould, 285; returns to N. Y. without Gould, 286

Opdyke George, delegate to constitutional convention, 213

Osgood. Vanderbilts's son-in-law, 279

Otis, Horatio $\mathrm{N}$., secretary of Erie, 280

Ottendorfer, Oswald, 323; elector, 367

Ottwell, John D., 307

Paige, Alonzo C., delegate to constitutional convention, 213

Palmer, George W., 93; 167; at Syracuse, 351

Palmer, H., temporary chairman Dem. Con. 334

Parker, of Cayuga, Senatorial election, 151

Parker, Alton B., jundge of Court of A peals, 221

Parker. Amasa J., delegate to constitulional convention, 213; member judiciary committee, 215 ; moves to strike out section on commission. 225; favors veto change, 243

Parker, A. X. of St. Lawrence, 353

Parker, John L., at Syracuse, 351

Parker, N. Wilson, 179; 365

Jarks, William M., 5:; 108

Parsons, Senator, absent from caucus, 150

Patrick, Gen. Marsena R., of Ontario, 53

Payne, Lewis F., witness Hale committee, 299; harbor master. 800

Pendleton, George II., followers op- 
posed to Chase and Seymour, 328; | Porter, Oliver, elector, 367

Presidential candidate, 230 : papers Post, George J., 356

rake up past, 336: letter to Wash- Potter, Waldo M., at Syracuse, 351

ington MicLean made public, 3\$6; Powell, Archibald C., nominated hurries to Washington, 381

Pecklam, Rufus W. Jr., judge of Court of Appeals, 224

Peckham, Rufus W., Sr., judge of Court of Appeals, 224

Pennsylrania, War record of, 29

Pentz, (Yeorge B., elector, 367

Perrin, Edward O., of Kings, 53: candidate for clerk of Court of Appeals, 361; unanimously elected clerk of Court of Appeals, :868; vote for clerk of the Court of Appeals, 1868,392

Pettibone. Stoughton, elector, 355

Peoples State Convention, and Republican State Convention, produce Union ticket in 1861,25

Philadelphia Convention, directed by Seward. Weed and Raymond, 83; Democrats realize necessity of conciliating Republicans. 83; Fernando Wood and Vallandigham asked to withdraw, 8\%; resolutions on emphatic endorsement of Johnson's policy, 84

Philadelphia principle, 408

Philbin. Stephen, War Dem. Cooper Union, 1868, 38 ?

Phillips, Wendell, oratorical genius enlivens campaign, 7.3

Piersom, Henry R.. Erie directory. $2 s 0$

Pierce, James F., introdnces motion in $\mathrm{N}$. Y. S. senate to investigate Erie, 280; senate committee on Erie. 280 ; majority report, 281 ; reports electoral ticket, 367

Pierrepont. Edwards, withdraws Dix's name. $10 ;-6$; member judiciary committee, 215; secret meeting at his house. 295; War Dem, Cooper Union, 18t8, chief speaker. 383; 384

Piper, Sherburn B., 32:

Pitts, E. L., 307

Platt. Moses R. e elector, 35.5; 351;

Pleasanton, General, Cooper Union. $148.27 \div$

P'omeroy, (ongresuman (Rad.), 187

Pond. proposes cont of ten. 218

Portur. John K., of Albany, 53

State engineer, 166; defeated, 208

Pratt. Daniel, 179

Presidential campaign, Times predicts military hero: Grant in minds of both parties, 1.92

Prince. L. Bradford. 307

Prindle, Elizur H., proposed 3 devartments, 227 : fixes age limit, 228

Private Miles O'Reilly, see Halpine, C. G.

Prosser, Erastus S.. caudidate for treasurer, 167

Prostitution, amount of property invested for immoral purposes; cost to City, 35

Pruyn, Robert H., candidate for Governor, 100; nominated for lientenantgovernor, 107; influence of Hoffman on, 131:137; Spencer pledges support to Robert H. Pruyn, 304

Radical Convention, heid at Philadelphia, Sept. 3, 1s66; comments of the press, 41. note

Radicals, success in Maine elections, $10 !$

Ramsdell, Homer. fails to appear as witness, 281

Ramsey, Josepl H., constitutional conv. 231: 35\%

Randall, H. S. . 360

Ramey. Luke, assemblyman, 287; testimony, $240 ; 291$

Rapallo, julge of rourt of Appeals, 224

Rath bm, George, 244, note

Ray, Henry, assemblyman, 287 ; involved in testimony. 288 ; testimony, 290; sensiti reness about bribery. 291

Raymond, Henry J., editor of Times enters Congress in 1765,27 ; collision with freeley, ti2: cousoles Democrats. 78; Seward takes him to see President with a purpose, 8:-4; address at Philadelphia convention causes his political death, 8t-5; removed fron chairmanship of Republican national committee, 8:; declines nomination by Conservative Republicans. 86; Greeley comments on declination, $S 6$; no 
sympathy among editorial colleagnes, 86; accused of having turned Copperbead, 85; letter to Ransom Balcom, 85-6; 90 ; open to conviction, 315; argnes that the country needs quiet, 377 ; 409; in accord with party, 413; see also Times

Reeves, Joseph, 307

Reynolds, Edwin R., elector, 35.)

Reynolds, Gideon, 108

Reconstruction, tive theories of, $f(i$, note; Times approves Congressional, 181

Republican (Chicago), attacks Slocum, 71

Republicans, State Convention, produces Union ticket with Peoples State convention, 25; absorb War Democrats, adopt name Union, 25 ; referred to as Unionists or Union Republicans, as Radicals, and as Conservatives, 88-!); Radicals dominate party till 1868,59 ; term Union dropped 1868. 89; convention of 1866 opens at Syracuse Sept. 5, 91; Charles H. Van Wyck, temporary chairman, 12 ; Lyman Tremaine permanent president, 92 ; convention of $186 t^{3}$ demand for new men, 92-3; State central committee, note. 93 ; convention of 1866 attitude of up-State editors, 94; convention of ' 6 ti platform, 95-6; attitule on $\mathrm{Re}$ construction, 96; convention of ' 66 editorial comments, 97-8; dissension in ranks, 130; Maine and Vermont give large majorities to, 132; win Penusylvania, Ohio, Indiana and lowa, 132; win New York by, 13:; Senatorial caucus, 150-2; rmmors of corruption. 153-4; State convention 1867. ticket, 166 , note; State convention, 'ti7; platform, 168; comments of the press, 16947 ; attack Dem.. 181; rally at Cooper Union, 18:'; attempts to counteract Dem. attacks, 200 ; denied, 202; discensions amoug, $202-3$; State convention of ' 68 ratifying horly; meets at Syracuse, 30:3; anti-lenton feeling, 303 ; contest between City factions, 30:; State convention of 1868 , ratifying boly, 303; reorganization committee under Mesers. Fithian and Murpliy, 304 :
Van Wyck pres., 306; State nominating convention held at Syracuse. July 8, 1868; ratifying body, 351 ; Twenty-third Street organization asks for reorganization, 352; Cochrane pres. con., 333; Griswold's nomination unanimous; 3 candidates for Lieut. -Gov.; Cornell nomination unanimons, $35+$; platform echo of (Licago, 356 ; State committee, 356, note; press comments. 357-9; appeal to Irish and Germans, 1568,380

Richardson, Gov. (Ill. ), 33j

Richmond, Dean, favors war, 25; holds ascendency, 2ii; 53 ; untimely death of, note, 101

Richmond, Henry A., Dem. State com., 1866, 108; 179; Dem. delegate, $324 ; 368$

Richmond, Van Rensselaer, nominated canal commissioner. 179 elected, 208

Rider, Ambrose L., elector, 355

Ruberts, Ellis H., editor Utica Morning Herald, leads Unionist delegates, 57; believes Johnson will stand "by the voice of the people." 78 ; presents Conkling's name, 150 307-8; contrasts Rep. and Dem. conventions, 35.$)$; gives his paper a very conservative tone, 388 ; see also Morning Herald (Utica)

Roberts. Marshall $O$., candidate for Gov., 351 ; elector at large, $355 ; 359$

Robertson, H. D., Rep. State com., 1866, 93; 186; Rep. State com. 1867, $160 ;$ : 307; at Syracnse. 1868. 251

Robinson, Lucius, nominated for comptroller, 49; esteemed by buth parties, 52; of (hemung, 5.8; 136 ; Ifil

Rockwell, William, Rep. Nat. detegate, $18698, .07$

Rodgers, Fli Wr., Rep. Nat. delegate, 1868,307

Root, Samuel, liep. State conı., 1868, 3.50

Rosenberg, Tammany naturalizer, 398 lioss, Elmore l'., I lem State com., 18(0:), 5.); 179; Dem. Nat. delcgate, 1868,$324 ; 368$

Ross., I. W., and M. (;. Kerr present minority ('ong. cons. report, 399 
Rowley, William C., elector, 367

Roy, James, elector; 367

Ruger, William C., chief judge of Court of Appeals, 224

Rumsey, David, moves to retain existing veto, $243 ; 245$, note

Russell, Cornelius A., Iem. Nat. delegate, 1868, 323

Sammons, simeon, 323

Sanford, George 11., I79; 32:3; 368

Saxe. John G, 10:3

Schell, Augustus E., interest in Erie settlement, 295; share in settlement, $29 t ; ; 323$; stands by Dem. ticket, $18 \mathrm{i}^{\circ}, 35 \%$

Schenck, weak position of, 204

Schermerhorn. Edmund H., War Dem., Cooper Union, 1868,383

Schermerliorn, 1saac M., 93

Scheu, Solomon, nominated State prison inspector, 179; elected. $20 \mathrm{~S}$

Schoonmaker, Marius, proposes ten senatorial districts, 239 ; and Messrs. Tappan and Champlaiu presents minority report, 2t:; 1

Schoecraft, Matthew I., elector, 367

Scluvetz, Frederick, elector, 35.5

Schumaker and Cassidy present minority suffrage report, 231

Schurz, Carl, temporary chairnan Chicago convention, 311 ; at Syracuse, I 565,385

Scott, George B. . 179

Searle, Gideon, 188

Seldon, Henry R., elector at large. 3.5

Selkrig, nominates Cornell for lieut.gov., $35 \frac{1}{4}$

Selye, Lewis, wins election orer Roswell Hart, 130 ; 137 ; Radical candidate for Congress. 359

Sedgwick, eand. for recorder, 135

Sesisions, Walter L., 2,i2; refuses to serve, $85: 3$

Seward, William H., regarded as leader of conservative Unionists, 27; leader of Johnson faction, 59 ; addresses his neighhors in Auburn, 73 ; victim of President's attempt to organize new party, 87-88; accompanies Johnson agaiust his will, 88 ; loss of influence, 128 ; address at Auburn, 1868, 390; federal patronage, $: 278$; 407 ; grasp nerreless, 404
Sexton, Seymour, :507

Seymour, Huratio, defeats Wadsworth for Gov., 1862, 24; cautious advisor, 25 ; influence on increase, 26; defeat desired, 44; of Oneida, 44; receives 361,264 votes, 45 ; fails to receive presidency of Albany convention, 48; admits national affairs have $\mathrm{im}$ proved, 66; Democratic organs sent to divert attention from Chicago platform, 72; ends campaign at Sencea Falls, Nov. 5, 72; prominent at leus. convention; struggle with Hoffiuan, 17\%; made chairman of convention press comments. 173; speaks at Iem. ratification meeting. $191 ; 192$; speech in Dem. Convention, 32.); delegate at large, $32: 3$ Herald and Evening Post accuse. 329 ; pres. Dem. conv., 336; address, $: 337$; landslide for, 341 ; press comments ot nomination, 344 ; announces that any change must include him, 382; ridiculed, 383 ; invades West. :38t; electoral vote, 1868, 39:; World praises, 403; 411

Shafer, Senator, $10 \%$

Shaler, Alexander, elected supervisor, $1: 15$

Sharp, George H., 307

sharpe, G. G. (Colonel), Cooper Union, 1868, 379

Shepard, James G., elector, 367

Sherman, 3. W.. Dem. State com., 1366,107

Sherman, John (Senator), 5-20 bonds could be paid in greenbacks, 167 ; 379

Shirmer, elected coroner, 135

Shotts, Assemblyman caucus teller. 151

Sickles, Daniel E., 58; delegate at large, $300^{\circ}$; moves unanimous nomination for Colfax, 313; Cooper Union, 1668, 379

Sickles, IIenry J., 324

Sigel, Franz, named for lieut.-gov., 354

Skidmore, Director (Erje), fined, 297

Sloan, Samuel, War Dem., Cooper Union, 1668,383

Slocum, Irnry W.. nominated for secretary of state, 49; friends scout 
idea of his accepting Dem. nomina- Stewart. Congressman, (Conser.) 6th rion. 51; of Onondaga. $5: 3$; Unionist dist. 136

journals make capital out of his change of faith, 71; Carroll Sinith gives list of his supporters, 71 : attacked freely by Syracuse Iaily Standard and Clicago Republiran, 71 ; endorsed by Sherman, Dix. Sickles, Cochrane and others, 75; candidate for Governor, 100; retires in favor of Ioflinan, $101 ;: 54-;$ 365 ; elector-at-large, 367

snith. (harles E. (of Albany). nominates I ra Harris, 1.51

Suith (of Fulton) proposes amendment to judiciary article, 216

Smith, Carroll E., editor of Syracuse Daily Journal, defends Slocum, 52; confines comments to State. $140 ; 349$

Snith. F. Delafield, Thomas Murplyy and A. ( $)$. Ylumb approve list of contestants, 304

Smith, Henry, temporary chaiman, 352

Smith, Lewis E., com. State convention, 1868, 353, note

Snith, Orrin W., 361

Smith. Washington J., withdraws in favor of Frank B. Gallagher, 107-8

Smythe, Henry A., proposed impeachment of, 158

Soldiers, treatment of Union, in Southern prisons, 127 , note

Spencer, Charles S. , 59; 9.5; 96; 159; distributes copies of Tribune; assails Twenty-third street organization, 164; nominates Iudson Lawrence, 166; present at ('ooper Union rally, 190; convention speech. 304; $307-8$; forces admittance of Southern votes, 311 ; at syracuse, 351 ; objects to committee, 352 ; mores for intornal ballot, 354 ; elector, 355

Spriggs, J. T., 53

Stanton, Elizabeth Cady, rums for ('ongress. 136; 337. note

Stebbins, Charles W., $323 ; 324$

Stebbins, Henry $(\dot{x}$. , eandidate for speaker, 374 ; War lem., (oxper Union, 1868, 383

Stcedwell, E. A., elector, 355

Stevens, Thaddeus. controls Pemsylvania Union convention, 48; leader of l'ennsylvania Radicals, 81; Ecening. Journal predicts overthrow, 203; disgust with, 410

Stewart, Alexander T., elector. 355; War Dem., Cooper Union, 181:8, :8:

Stewart, Rohert. elector, 355

Stewart, Thomas E. . 107

Stewart, William R. 807 ; reports electors-at-large, 855

Stone, Ruby H. clector: 367

Strong, Jolin M., nominated for inspector of State prisons, name withdrawn, 368

Stuart, Robert I., War lem.. Cooper Union, 1868, 388

Sturtevant, Alvin, 167

Suifiage. Pres. Johnson, favors qualified negro suflrage, 46 ; north takes attitude of Mississippi convention as indicative of fonthern sentiment. 48 ; public sentiment at first against negro, note, 62; woman's ticket, 1866. 136; majority report by Ereeley, 233; qualifications, 234; minority report by Cassidy and Shumaker, 234 ; registration compulsory, 235; women endeavor to advance cause, 236; Wales proposes woman sufliage, 236, note; Curt is champions woman's cause, 237 ; pripudices against negroes continues. 237; negro suffiage stumbling block, 212

Sunner, Charles, controls Massachusetts Union convention. 48; with Chase visits l'resident, fï; leader of Massachusetts Radicals, S1; disgust with, 410

Sun considers Grant tower of strength, 317 ; favor's Chase. 326; characterizes Blair and Seymonl. 346; editorial on 1)em. Siate con., 369; makes only true prediction. 372 ; admits Grant's election. 381 ; denommees election frands. 101 ; Grant will pacify country, 402; editorial on charter election, 405

Sutherland, Citizens Assoc. takes up charges against, I!18

Sweeney, James M . elector, 867

Sweeny, Peter B. hecomes prominent factior in Democracy. 26; $5 . ;$; 108; 179 ; gives city $\$ 200,000,201$; appointed to Frie receivership, 279 ; made Erie director. :-17; $360 ; 368$; furnished brains for 'Tweed Ring, 377, note

Sweet fylvame H. of (meida, 53 
Swift. John L., opinion of Pendleton's candidaev. 334

Swinging round the cirkle, 87; campaign book by l'etroleum V. Nasby, 117, note

Syracuse, home of Barnum and Slocum center of up-state eampaign, 69; center of Dem. np-State campaign, 131

Taber, Congressman (Dem.), 1st dist., 1866,136

Taggart, Judge, dissatisfaction over overthrow, 202

Talmie, Collin, 323

'Tammany Hall, utilizes foreign element to help, Democracy, 26; gains over Regency and Mozart Hall, 2ti; sonrce of power in vile conditions, 35; rewards Mozart Hall, 175; public awakening to machinations of, 200 ; John Kelly calls for loan, 200; Judge Morris attacks, 363; press comments on frauds of, 394 ; naturalization committees under Gale and Rosenberg, 398

Tappan and Messes. Schoonmaker and Clamplain present minority report, $243-1$

Tarbox, assemblyman, caucus teller, 151

Temperance, State convention meets in Albany, 171

Ten Broeck, Cornelius, eandidate for elerk of ( Cout of Appeals, 361

Ten Eyck, enlarges Stite com., 362

Tennessee, accepts anendments and is restored to Union, 82

Terwilliger, James, $167 ; 356$

Thayer, C. S., speaker Dem. rally, $2(i 5)$

Thayer, Franeis S. senate committee to investigate legislative corruption, 298

Thompson, Henry, direetor Erie, fined, 297; pays Payne, story relative to Caldwell, 300; 301

Thompson, R. W., chairman commitiee on platform, 312

Tilden Henry A., $\$ 23$

Tilden, Samuel J. discredited, 48-9; $90 ; 108 ; 174$; delegate to constitutional convention, 213; casts doubt on legality of submission, 247; prominent at Dem. convention; calls to order, 172; calls Dem. Convention to order, 322 ; delegate at large, 323 ; accused of conspiracy. $342 ; 360$; calls 18 tis convention to order, 361 ; 368 ; keynote for Demoerats, 372 ; stands by ticket, 1868. $38 \%$; secret eircular attubuted to; denjes knowledge of circular, 893 ; arpires to Seymour's place in party, 412

Tilton, 'Tlieodore. Chase's energetic friend, 326 ; see also Indeperdent, The

Times, The, mable to appreciate Demoeratic clange of heart. 49 ; conment on Horace (ileeley, 92; prediction of, 13: note; loyal servant. 315 ; devotes strength io financial rebutul. 376 ; final arguments on Griswold and Ifoflman. 391 ; denounces election frauds. 401

Times (Chieago), questions life of Democracy, 1.14

Times (Trov) defends (iriswold, 375

Titus, Charles M., elector. 855

Toplift, E. C., 188

Tormance, C. C., proposes A. P. Lanning, $36: 3$

Toncey, Sinclair, 353

'Townsend, John D., relations between the Frie and Tweed. 292

Townsend, Martin I., discusses constitution, 257; speceh of 1868, 379

Townsend, Solomon, 245, note

'Travis, nominates Greeley. 151

Tremaine, Lyman, permanent president Syracuse (Rep.) convention, 92 ; life, 146-7; comment on comkling's election, 152-3; speaks at Rep. conrention, 306 ; delegate at large, 306 ; reports resolutions, 308 ; eandidate for (rov., 351

Tribune, The. hurls charges at Gen. Slocum. 67; opinion of Conkling, 155 ; engages in war with all consedrative journals, 19.5 ; blames N. Y. Rep. papers. 209; harms work of convention, 259; attacks Hoffiman for connection with Tweed, 377 ; denounces election frauds. 401; see also Greeley, Horace

Tucker, (ijdeon T. surrogate, 103; elected surrogate, 135

Tweed, William Marcy, becomes prominent factor in Dem. party, 26: 
116; candidate on Union Rep. and Van Brmt, froprge B. . elected. 208

Tammany tickets. 197; 279 ; senator, |Van luren, fohn, nominated attorneyon Vanderbilt side. 256 ; extending porver in legislature, 292; marle Erie director, 297; $323 ; 324$; vicepres. Dem. con., 336; leads Tammany forces, 360 ; leads cheers for Hotfiman. 363 ; gross frauds of. 343 ; 399 ; would not be tolerated to-day, 412

Union lealgne Clnb. clarges fraud, 394

Unionists, factions among, 24 ; origin of. 25 ; gain cont rol of state in 1863 . 20 ; evidence of dissensions among, 26 ; Greeley-Weed fend flourishing in $186 \overline{0}, 2 ;$ N. Y. State ticket for 1864,$44 ;$ N. Y State ticket for $1565,5 \%$; conrention opens in syracuse, Sept. $20,1865,56$; convention of 1865 , Radical journats comment. 万ti; delegates led by Ellis $H$ Roberts. 57 ; Riddicals claim majority by 70 to 50.58 ; Conservatives assert control. 5!; controlled by Henry J. Raymond and Thurlow Weed, jt; Preston King and William H. Seward represent factions contending for Johnson 's favor, 59; Radicals affiem right of loyal Southerners to vote in reorganization of State governments, ti1; platform. 63-4; editorial comments, 64; strong majority. 77; national convention of 1866 opens at Philadelphia. Ang. 14, 82; preliminary consention held at Saratoga, 90; Homer Nelson. temporary chairman. 90; elect eight delegates-at-large to Philadelphia convention, 90 ; State convention of 1867 meets at Syracuse, Sept. 25 . 159; editorial conments, 162; national couvention of 1866 , see also Philadelphia eonvention; Republican

Unicerse. 'The, comulents on Jolnson's Fenian attitude. 122 general, 49; of New York, 53; attacks Seymour and Vallandigham, 67; Cireeley comments on attick. 67: great efforts in campaign, assisted by Montgomery Blair and (ien. John Cochane, 69; dics l)et. 14,1866 ; loss to party. 131

I an Buren, Thomas B., and Indrews reply to spencer, 30.5

Van ('ampen, (ienrge, 245, note

Vin Cott, Joshuta M., nominated for attomey-general, 166; defeated, 208; delegate to constitutional convention, 213; member judiciary conmittee, 215; amendment presented by, 242; origin of convention's jowers, 247; tempory chaiman. $303 ; 307-8$

$V$ anderbilt, Cornelins, career of; comparison with Drew. 268; buys heavily. 274; unsuspectingly purchases Erie bonds. 277; prerents panic, 278; influence at Mlbany waned, 292; withdraws, 293; plans settlement with I)rew, 294; wishes as to settlement, 295 ; terms of settlement, 296; War Dem., Cooper Union, 1868, 383

Vanderbilt. Cornelius, Jr., witness Hale committee, 299

Vauderpoel, Aaron, War Dem., Cooper Union, 1868, 38:3

Van Horn. ('nng. Rad. 29th dist., 1866,137

Van Schaack l lavid, elector. $: 67$

Van Valkenburg I. A., Rep. State com . 1868, $356^{\circ}$

Van Vorst. H. C.. elector. 355

Van Wyck. Charles H., 59; temporary chairman Syracuse (Rep.) convention, $92 ; 136 ; 1.5 \%$; pres. Rep. convention; censures Johnson. :30t; candidate for ( iov.; declines to run, 352

Vance, Z. B. Blair in class with, 380

Vermont, elects Rep. ticket, 152

Vallandighan, Clement L., asked to Yerplanck. on un restricted sufliage. withdraw from Philadelphia convention, $83 ; 343$

Van Anden, Isaac, elector. 367

Van Arnan, Cong. Rad. 31st dist. $18^{\prime} i 6,137$

208

Voorhees, of Indiana, speaker at Dem. rally, 20,j

Voorhies, substituted for Jacobs, 321 . nute 
Wade, Benjamin, named for vicepres., 310 ; 312 ; third for vicepres. , 313 ; radical, 380

Wadsworth, James $\$$., nominated for Gov.. 1862, as Gireeley candidate, 24

Wagstaff, Alfred, Kep. del. Ist dist., 1868,307

Wait, A. D., Rep. State con. 15th dist., 1568, 3.5;

Waite, D. H., severs connection with Chautuuqua Democrat, 203

Wakeman, const. conv.. opposed to increase in judges, 217; motion for re-election of judges carries, 223

Waldo, A. B., Dem. State con. 4th dist., 107

Waldo, Christopher A., Dem. State con. 6th dist., 53

Wales, Gideon, proposes suffirage for taxpaying women, 236, note

Walker, Charles C. B., Dem. State con. 7th dist., 1865, 53; 107; Dem. State con., 1867, 179; 1868, 368

Walrath, C. H., Dem. State con. 6th dist., 1866, 107

Ward, Cong. 27th dist. Jem., 137

Ward, Eugene, Republican alderman, 143

Ward, Gov., calls Raymond political apostate, 85

Warren, Joseph, del. 30th Cong. dist. , 1868, 324; Dem. State con., member-at-large, 368

Warren, Moses, del. 15th Cong. dist., 1868, 323

Webb, W. H., War Dem., Cooper Union, 1868, 383

Weed, Smith M., favor adjournment, 247 ; aspires to lieut.-governorship, 361

Weed, Thurlow, rise of feud with Horace Greeley, 24; power broken by rise of Fenton and Radical faction, 27; urges Unionists to drop former Democrats, 58; prevents test vote, 59: praises resolutions of Unionist convention, 64; suspected by Democrats; attitude of Daily Courier and Union, 130; head of Twenty-third Street party, 160; assails (treeley in Commercial Advertiser, 163; endorses Grant and Colfax, 317; favorite diversion of, 327 ; federal patronage, 378 ; severe on Blair, 380; finds campaign a pathetic,
402 ; 407 ; remained true to Philadelphia principle in 1866, 409; power lost, 412; see also Commercial Advertiser and Albany Evening Journal.

Weidrick, M., elector, 355

Welles, Gideon, Sec. of Navy; throws side-light on Seymour, 342; statement as to payments on Monitor, 375

Wells, David A., compiles campaign book, 373

West, Dewitt C., elector, 367

Westervelt, Jacob A., War Dem., Cooper Union, 1868, 383

Wheaton, Charles, del. 12th Cong. dist., 1868, 323

Wheeler, Elisha P., elector, 355

Wheeler, William A., suggested for lieutenant-gorernor, 93; delegate to constitutional convention, 213; pres. of const. conv., 214

Whiskey frauds, revenue officials discover, 194; Herald, Evening Post, and World give especial attention to, 194-5; Nation points out loss and waste, 195

White, Andrew D., nember of senate committee to investigate New York City conditions, 34 ; seconds Conkling's nomination, 148; 151 , note; reason for advocating Conkling, 154 ; 159; comments on Seward's speech, 1868, 390; frauds well known to, 394

White, William B., Republican alderman, 143

White House Speech, Johnson disgraces himself, 81

Wickham, William, delegate to constitutional convention, 213

Wicks, John J., canal commissioner, 137

Wildee, O. C., Rep. Nat. delegate, 1868,307

Williams, Dr. Julian T., political doctor for Gould, 285

Williams, Stephen K. (Senator), of Cayuga, Times accuses, 188; Citizens' Assoc. takes up charges against, 198

Williams, William, Dem. Nat. delegate, 1868,324

Williamson, Amos J., Rep. State com., 93 
Willson, Hugh B., charges W. J. Worth, Jacob, elector, 355

Humphrey with corruption, 197

Wilson, Benjamin, Rep. State com., 1868,356

Wilson, Henry, named for vice-pres., $310 ; 317$

Wing. Halsey R., Dem. Nat. delegate. 1868,323

Winslow, John S., Rep. State com., 1866,93

Winslow, John F., Griswold's partner, 374

Winslow, Morris, elector, 355

Wise, Henry A., Blair classed with, $3 \times 0$

Woman Suffrage, central comnittee presents resolution to N. Y. con., 337 , note; see also suffiage

Wood, Congressman (Dem. ), 9th dist., 1866,136

Wool, Fernando, 25; influence dimin. ished, 26; asked to withdiaw from Philadelphia convention, 83; money spent to elect, 30.5

Woodford, Stewart L., of Kings, 92: nomination of, 93 ; 132 ; elected lieut.-gov., 133: speaks at Rep. conrention, 306; candidate for Gov., 352 ; nominated for Gov., 354

Work, Frank, director on board Erie R. R., 271; petitions for injunction, 272 ; director of Erie, 274; interest in Erie settlement, 295; share in settlement. 296

Workingmen's convention, delegates given seats in Den. Nat. con., 336

World, The comments on change of Democratic ideas, 49; considers I)em. ticket not strong, but liberal, 53: resents charge against Slocum, 67; prophesies future victory in face of defeat, 77: predicts loss of Conservative vote, 97; gives lie to Rep. olgans, 116; consoles Democrats, 137; considers Counolly honest and economical, 143: assails Conkling, 155; summarizes candidates, note, 180; reviews canal frauds under Rep., 206; warns Democrats, 211 ; on the Chicago convention, 316; attack on Grant, 374; attacks Griswold, 374; seconds Hoffiman, 376 ; on Grant and Blair, 380; demands change in ticket, 381 ; fails to mention election frauds, 401 ; praises Seymour, 403

Worth, Samuel, cand. for nomination to State treasurer, 1867, 179

Wright, William W., nominated for canal commissioner, 107

Wyckoff; Samuel S., elector, 355

Young, Campbell II., named for clerk Court of Appeals, 355; vote for clerk of the Court of Appeals, 1868, 392

Young, John Russell, represents Greeley at Syracuse, 351

Young, Solomon C., discussion of district plan, 239

Younglove, Truman G., 307; 352 


\section{VITA}

THe anthor of this monograph was born May 6, I884, at Syracmse, New lork. Ifter receiving his preparatory erlucation in the public schools of that city he entered Syracuse Lniversity. fron which he graduated in 1906 with the degree of Bachelor of Philosophy. The next two years were spent at Syracuse following courses in History and comses in Civil Law, for which he received the degrees of Master of Philosophy, in $1,0 \%$ and Bachelor of Laws, in 1908. He was admitted to the New York State Bar in Inly, roos. From the fall of roos until the present he has been in residence at Columbia Lniversity as a candidate for the legree of Doctor of Philosophy. At Syracuse I niverity the anthor attended courses given by Professors I Blliam H. Mace and Alexander C. Flick: and at Columhia Iniversity courses given by Professors John W. Burgess, William \. Puming. Herbert 1. Osgood. William R. Shepherd and John Bassett Moore. The author was an Assistant in the Department of History. Syracuse University, for one year, and has, also, taught History in the Prospect Heights School for Boys. Brooklyn, I9IO-II: in the Twenty-third Street Ir. M. C. A. Night School, I9I I-I3; and for the same period in the College of the City of New York. 




<smiles>C1=C[SiH2][SiH]1</smiles> 